\title{
Geological
}

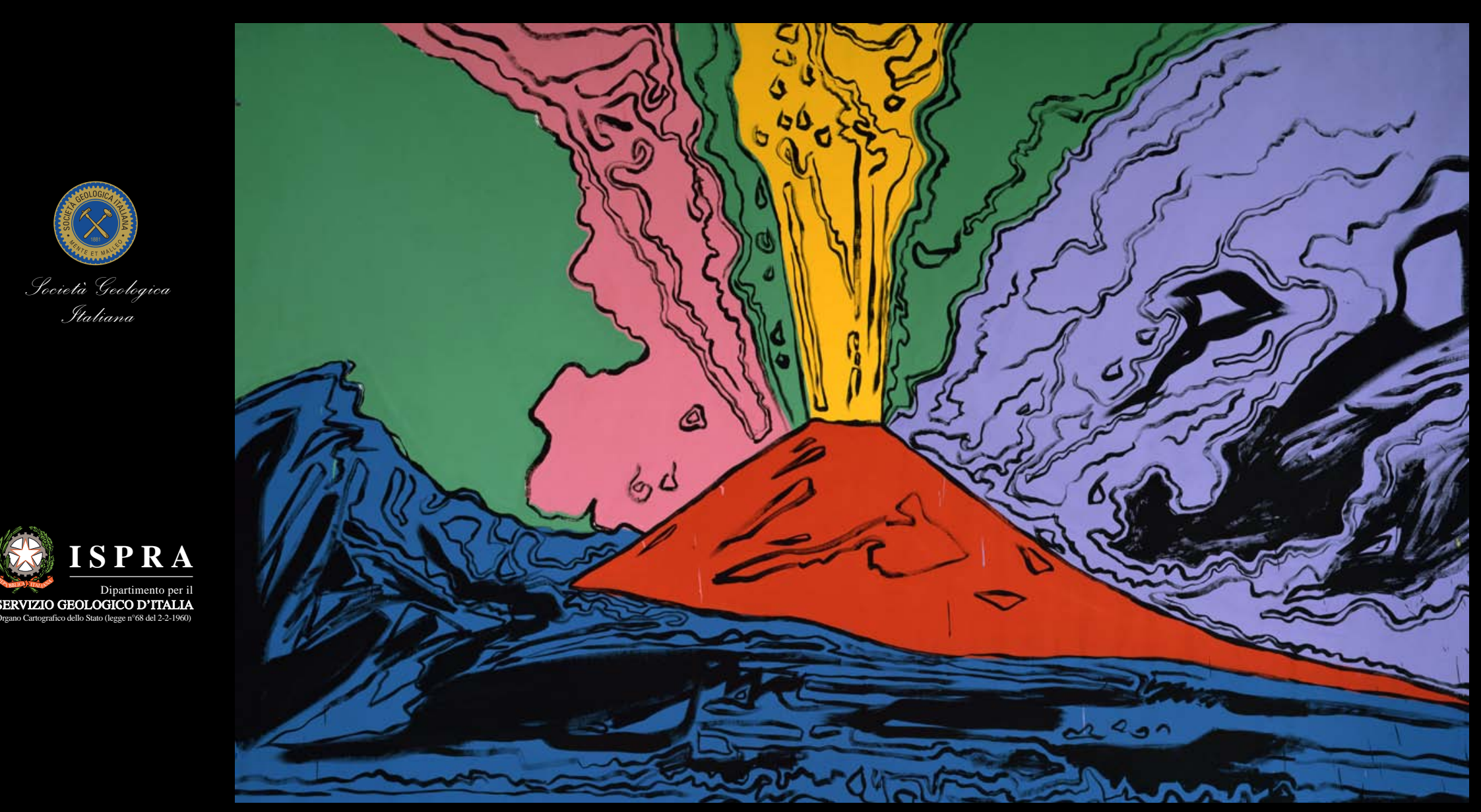

Field

Trips

2017

Vol. 9 (1.1)

The Vesuvius and the other volcanoes of Central Italy

Goldschmidt Conference - Florence, 2013

DOI: 10.3301/GFT.2017.01 


\title{
GFT - Geological Field Trips
}

Periodico semestrale del Servizio Geologico d'Italia - ISPRA e della Società Geologica Italiana

Geol.F.Trips, Vol.9 No.1.1 (2017), 158 pp., 107 figs. (DOI 10.3301/GFT.2017.01)

\section{The Vesuvius and the other volcanoes of Central Italy}

\section{Goldschmidt Conference, 2013}

\section{Riccardo Avanzinelli1, Raffaello Cioni1, Sandro Conticelli1, Guido Giordano2, Roberto Isaia3, Massimo Mattei2, Leone Melluso4, Roberto Sulpizio5}

\author{
1. Università degli Studi di Firenze \\ 2. Università degli Studi di Roma 3 \\ 3. Istituto Nazionale di Geofisica e Vulcanologia \\ 4. Università degli Studi di Napoli "Federico II" \\ 5. Università degli Studi di Bari
}

Corresponding Authors e-mail addresses: sandro.conticelli@unifi.it - raffaello.cioni@unifi.it

Responsible Director

Claudio Campobasso (ISPRA-Roma)

Editor in Chief

Gloria Ciarapica (SGI-Perugia)

Editorial Responsible

Maria Letizia Pampaloni (ISPRA-Roma)

Technical Editor

Mauro Roma (ISPRA-Roma)

Editorial Manager

Maria Luisa Vatovec (ISPRA-Roma)

Convention Responsible

Anna Rosa Scalise (ISPRA-Roma)

Alessandro Zuccari (SGI-Roma)
ISSN: 2038-4947 [online]
Editorial Board

M. Balini, G. Barrocu, C. Bartolini,

D. Bernoulli, F. Calamita, B. Capaccioni,

W. Cavazza, F.L. Chiocci,

R. Compagnoni, D. Cosentino,

S. Critelli, G.V. Dal Piaz, C. D'Ambrogi,

P. Di Stefano, C. Doglioni, E. Erba,

R. Fantoni, P. Gianolla, L. Guerrieri,

M. Mellini, S. Milli, M. Pantaloni,

V. Pascucci, L. Passeri, A. Peccerillo,

L. Pomar, P. Ronchi, B.C. Schreiber,

L. Simone, I. Spalla, L.H. Tanner,

C. Venturini, G. Zuffa.

\section{http://www. isprambiente.gov.it/it/pubblicazioni/periodici-tecnici/geological-field-trips}

The Geological Survey of Italy, the Società Geologica Italiana and the Editorial group are not responsible for the ideas, opinions and contents of the guides published; the Authors of each paper are responsible for the ideas, opinions and contents published.

Il Servizio Geologico d'Italia, la Società Geologica Italiana e il Gruppo editoriale non sono responsabili delle opinioni espresse e delle affermazioni pubblicate nella guida; l'Autore/i è/sono il/i solo/i responsabile/i. 


\section{Information}

General information .5 Emergency contact numbers, hospitals and first aids .........5

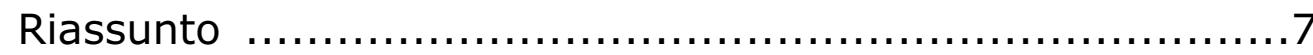

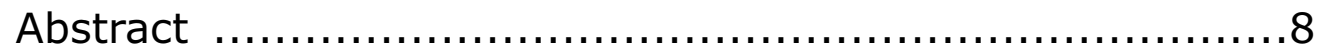

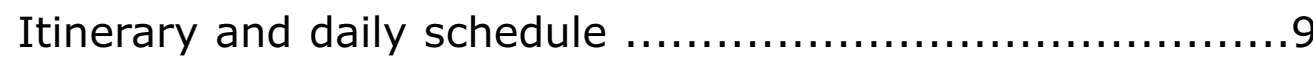

\section{Excursion notes}

\section{Geological setting} .11

The alkaline potassic rocks and

the Central Mediterranean Region ..............................11

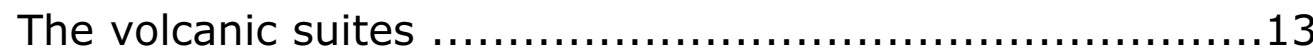

The Geodynamic framework .................................. 17

Present day tectonics and kinematics .........................19

Structural and geological features of the extensional

Tyrrhenian margin .21

Geochronology time of Italian Peninsula volcanism ........... 25

Origin of Italian magmatism ................................29

Subduction-related metasomatism ............................33

Geodynamic scenario

\section{Itinerary}

1st Day - Somma-Vesuvius Volcano .42

Roman Province: The Neapolitan District ....................42

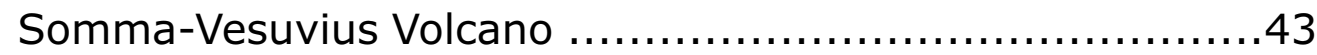

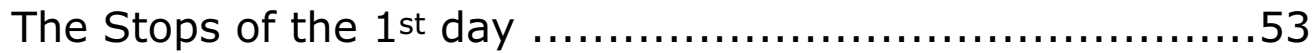

STOP 1.1: the Somma caldera and the Vesuvius crater ....54 STOP 1.2: the Villa di Poppea (Oplontis) - Torre Annunziata ...56 STOP 1.3: Herculaneum excavations

2nd Day - Campi Flegrei and Roccamonfina Volcano ..60 The Stops of the morning of the $2^{\text {nd }}$ day .70 STOP 2.1: the volcanic structure of the Campi Flegrei. Panoramic view from the hill of Posillipo in Naples .71 STOP 2.2: the volcanic and hydrothermal activity in the volcano Solfatara .73 STOP 2.3: the Serapeum and the bradyseism ................ 75 Roman Province: the Latian Districts ..........................77 Day 2 (continue): Roccamonfina Volcano ......................78 The Stops of the afternoon of the 2 nd day ........................ 83 STOP 2.4: Monte Lattani and the post-caldera activity ........84 STOP 2.5: Sessa Aurunca, the caldera-forming ignimbrites .... 84 
3rd Day - Colli Albani Volcano ............................ 86

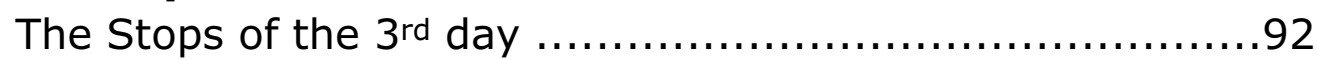

STOP 3.1: Vallerano quarry to observe the melilite-bearing pre-caldera lavas

STOP 3.2: the ESMAN (ex IMATER) quarry,

the caldera-forming ignimbrites ...........................93

STOP 3.3: Albano maar succession .........................94

STOP 3.4: Tuscolo rim and the caldera .......................96

4th Day - Cimino and Vico nested volcanoes ............96

Stops of the morning of the 4 th day ...........................102

STOP 4.1: Vitorchiano neighbourhood: "Peperino" quarry ...103

STOP 4.2: Via Sorianese - Santa Lucia .......................105

STOP 4.3: Vico Caldera rim .................................... 105

Day 4 (continue): the Vulsini district ........................ 107

Stops of the afternoon of the 4 th day $\ldots \ldots \ldots \ldots \ldots \ldots \ldots \ldots . . . \ldots \ldots 11$

STOP 4.4: Montefiascone: the caldera and the

Bolsena Lake .....................................................112

STOP 4.5: Montefiascone Volcano, the melilitite of the

caldera wall

STOP 4.6: Civita di Bagnoregio, the distal deposits of the

Bolsena Volcanic complex

114

STOP 4.7: thrown stones (autoc. "pietre lanciate") ..........114

5th Day - The Tuscan Magmatic Province ................116

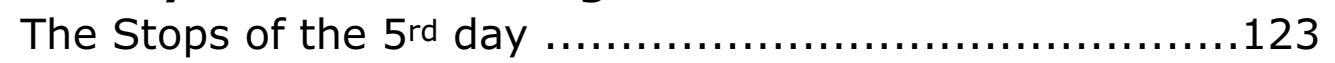

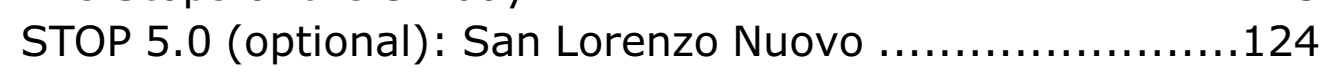

STOP 5.1: Acquapendente quarry of "selce" ..................124

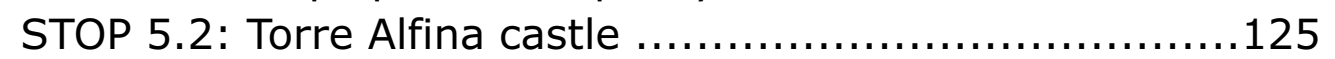

STOP 5.3: Radicofani neck ................................... 126

STOP 5.4: top of Monte Amiata ..............................128

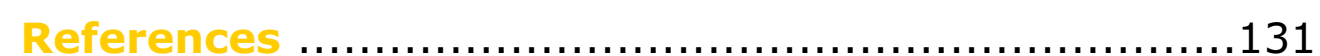




\section{General information}

The Italian Peninsula is unique in the world for the high number, more than fifty, of recent to active volcanoes characterised by extremely different petrochemical features and eruption styles. Eight of them erupted in historical times. Vesuvius, along with Etna and Stromboli, is one of the most famous volcanoes in the world. The report of the Pompei eruption made by Plinius the young might be considered the first paper on Volcanology. The Field Trip will start from Vesuvius and the Campi Flegrei, the two nearby volcanoes that encircle the city of Naples, merging the visit to the escavated ancient town of Hercolaneum to observe the geological record of the Pompei eruption, which brought to dramatically destroy all the towns around the Vesuvius, and the effect of the different eruption phases on buildings. In the following days the field trip will move from the Neapolitan area trhough the Roman Magmatic Province to observe the products and the volcanological features of the other Roman volcanoes make stops at Roccamonfina, Colli Albani (Alban Hills), Vico, Cimino, Vulsinian, Amiata and Radicofani volcanoes, to have a complete picture of the whole volcanic activity of the Tyrrhenian border of the Italian Peninsula.

\section{Emergency contact numbers}

112 - Carabinieri

113 - Police

115 - Fire figthers

118 - First Aid

\section{Hospitals and first aids}

\section{Vesuvius area}

Presidio Ospedaliero Maresca di Torre Del Greco,

Via Montedoro - tel. +39(0)818824033

Torre del Greco (NA)

Campi Flegrei area

Ospedale S. Maria delle Grazie,

Via Domitiana, La Schiana - +39(0)818552111

Pozzuoli (NA)

\section{Roccamonfina area}

Ospedale San Rocco

Via Sessa Mignano

Sessa Aurunca (CE)

\section{Colli Albani area}

Presidio Ospedaliero "San Sebastiano"

Via Tuscolana, 2 - tel. +39(0)693271

Frascati (Roma) 
Colli Albani area

Policlinico Casilino

Via Casilina 1049, 169 - tel. +39(0)623188

Roma (RM)

Vulsini area

Ospedale Civile di Montefiascone,

Via Donatori di Sangue - tel.+39(0)7611860233 Montefiascone (VT)

Naples area

Ospedale Loreto Mare,

Via Amerigo Vespucci 26 - tel. +39(0)81201033

Napoli

Roccamonfina area

Ospedale civile Santa Scolastica

Via San Pasquale - tel. +39(0)77639291

Cassino (FR)

\section{Roccamonfina area}

Ospedale Teano

Via Roma - tel. +39(0)823506111

Teano (CE)

Colli Albani area

Ospedale San Giuseppe

Via Olivella km 1, 41 - tel. +39(0)693271

Albano Laziale (Roma)

Vico-Cimino area

Ospedale Belcolle

Strada S. Martinese - tel. +39(0)7613391

Viterbo

Amiata-Radicofani area

Presidio Ospedaliero Amiata Senese

Via Trento - tel. +39(0)5777821

Abbadia San Salvatore (SI). 


\section{Riassunto}

L'escursione è dedicata all'osservazione e discussione delle caratteristiche vulcanologiche, mineralogiche e geochimiche del magmatismo ultrapotassico, sia a leucite sia privo di leucite, e delle rocce shoshonitiche e calco-alcaline ad esse associate.

L'Italia centrale rappresenta infatti un'area geologica unica sul pianeta nella quale rocce vulcaniche recenti variabili da ultrapotassiche a sub-alcaline affiorano in stretta associazione spazio-temporale in risposta ai processi legati all'evoluzione geodinamica del Mediterraneo centrale e connessi con il riciclaggio di sediment crostali all'interno del mantello terrestre attraverso meccanismi di subduzione.

Il primo obiettivo dell'escursione è l'osservazione delle variazioni petrografiche e geochimiche presenti nella fascia vulcanica di età compresa tra l'Olocene e il Plio-Pleistocene che corre lungo il margine tirrenico della penisola italiana.

Il primo giorno è dedicato al Vesuvio, ed in particolare all'attività recente che ha portato alla formazione del "Gran Cono" a partire dall'eruzione del 79 d.C. cosidetta di Pompei. Le successioni vulcaniche della Villa di Oplontis a Torre Annunziata e degli scavi di Ercolano sono l'oggetto dell'analisi di dettaglio per ricostruire gli eventi di quest'ultima eruzione.

L'attività del secondo giorno è incentrata sull'analisi dei prodotti del vulcanismo dei vulcani dei Campi Flegrei e di Roccamonfina, con l'osservazione delle principali ignimbriti che hanno portato alla formazione delle caldere dei due vulcani, oltre ad osservare i prodotti post-calderici che hanno invaso le due depressioni.

Nel corso del terzo giorno è possibile osservare al vulcano dei Colli Albani le lave ultrapotassiche a melilite, la successione vulcanica del Lago di Albano e, infine, le caratteristiche vulcanologiche del cratere di esplosione che ha formato il lago stesso. Nelle soste pomeridiane il partecipante è guidato all'osservazione delle ignimbriti "Tufo Lionato", "Pozzolanelle" e "Villa Senni" appartenenti alla sequenza vulcanica che ha portato alla formazione della caldera.

Il quarto giorno è dedicato inizialmente all'osservazione dei prodotti melititici del vulcano intrappenninico di San Venanzo, per poi spostarsi ad osservare la transizione da magmatismo ad affinità lamproitica a quello ad affinità leucititica al passaggio dai prodotti del Vulcano Cimino a quello di Vico. Inoltre, è possibile osservare la caldera poligenica del Vulcano di Vico con il suo omonimo lago craterico, interrotto dalla presenza del cono intracalderico di Monte Venere. 
Durante il quinto giorno, si potranno osservare le rocce lamproitiche e gli xenoliti ultramafici del vulcano di Torre Alfina, la transizione lungo il condotto vulcanico da rocce calco-alkaline a rocce shoshonitiche ultrapotassiche al Vulcano di Radicofani, ed infine le rocce calco-alcaline alte in potassio del vulcano del Monte Amiata.

Parole chiave: Province magmatiche Toscana e Romana; Vesuvio, Campi Flegrei, Roccamonfina, Colli Albani, Cimino, Vico, Montefiascone, Bolsena, Torre Alfina, Radicofani, Amiata.

\section{Abstract}

The field trip is devoted to the observation and discussion of the volcanological, mineralogical, and geochemical characteristics of the most famous/infamous leucite-bearing and -free ultrapotassic rocks and their associated shoshonites and calc-alkaline terms, generated by recycling of sediments within the upper mantle via subduction.

Indeed, Central Italy represents a unique geological area, characterised by alkaline to sub-alkaline volcanic rocks generated at destructive plate margin with typical orogenic geochemical signature though to be generated by recycling of sediments within the upper mantle.

The first aim of the field trip is the observation of Pliocene to Holocene volcanic rocks and their changing in geochemistry with time in relation to the geodynamic evolution of the Italian Peninsula and of the Apennine Chain will be shown.

During the first day you will climb the top of the Monte Vesuvius Volcano, walk around the rim of the "Gran Cono" crater, look at the leucite-bearing rocks of the Monte Vesuvius Volcano, walk over the 1944 AD eruption; visit the Oplontis Villa archaeological site and observe the Pompei eruption sequence.

During the second day you will leave Naples to Roccamonfina Volcano. On the way you will made a brief stop at the Phlegrean Field to observe its caldera and the solfatara activity. Once at Roccamonfina Volcano the caldera and the rocks of the intra-caldera activity are observed.

During the third day you will arrive to the Colli Albani Volcano to observe melilite-bearing ultrapotassic rocks, the Albano Lake volcanic succession and eventually the feature of the explosion crater. In the afternoon Stops it is possible to look at the famous "Tufo Lionato" and "Pozzolanelle" units of the Villa Senni eruption belonging to the caldera-forming volcanic sequence. 


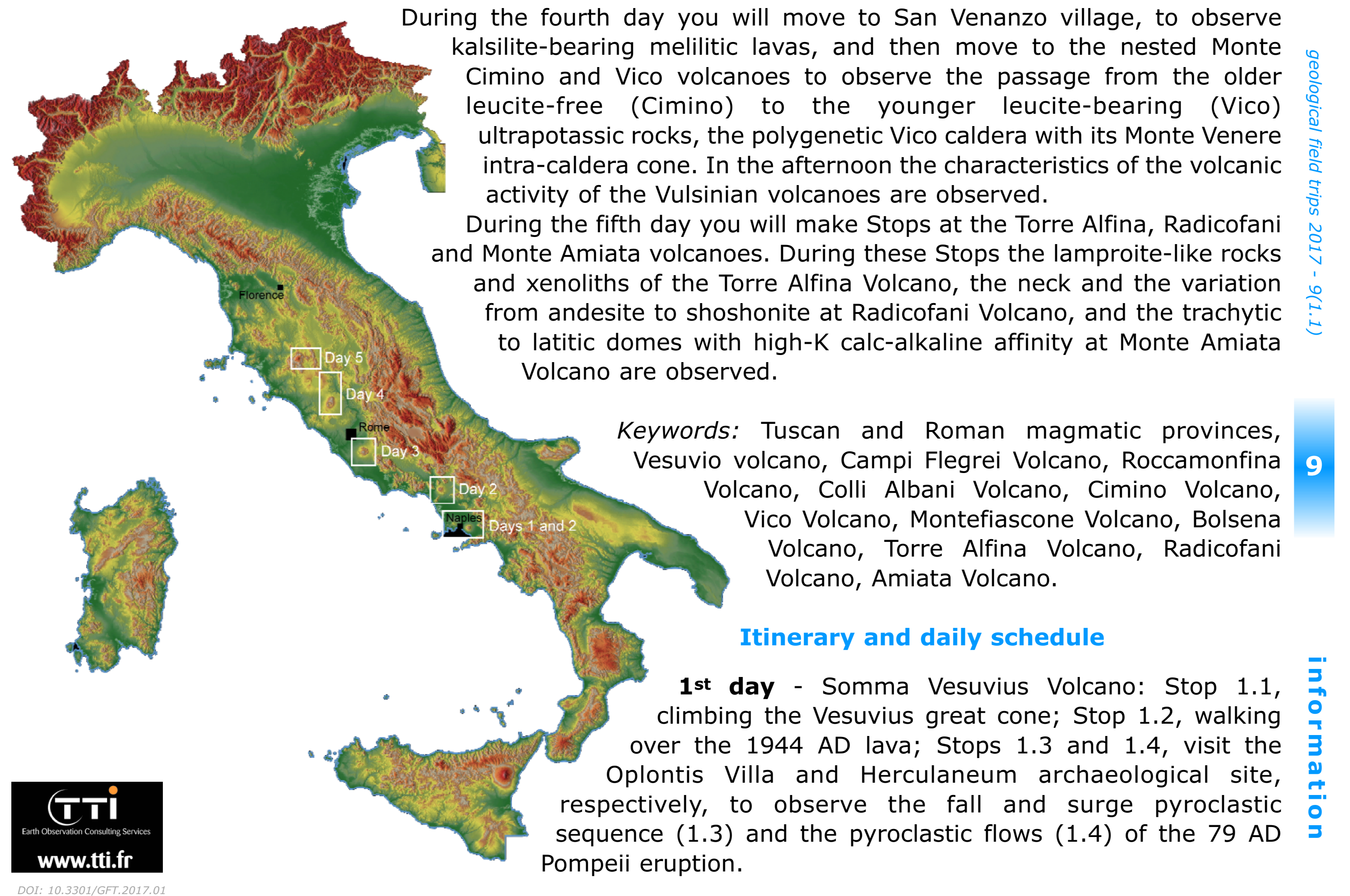


2nd day (morning) - Campi Flegrei Volcano: Stop 2.1, Posillipo Hill in Naples for a general overview of the recent volcanic structures within the; Stop 2.2, Solfatara crater, a young maar-type monogenic volcano with its present day fumarolic activity;

|2nd day (afternoon) - Roccamonfina volcano: Stop 2.3, to observe pre and post caldera products; Stop 2.4, quarry at Sessa Aurunca village to observe the "Brown Leucitic Tuff" and "White Trachytic Tuff".

3rd day - Colli Albani Volcano: Stop 3.1, Vallerano quarry to observe melilite-bearing pre-caldera lavas; Stop 3.2, IMATER quarry to observe caldera-forming pyroclastic flows; Stop 3.3, Fioranello road - to observe the ignimbrite and breccia of the "Villa Senni" eruption; Stop 3.4, Albano maar; Stop 3.5, Frascati road to observe the Tuscolo rim of the caldera with overview of post-caldera features.

4th day - San Venanzo Volcano (optional): Stop 4.1, observe the "kamafugitic" kalsilite-bearing melilitic lavas, walk around the maar and lava flows; Cimino Volcano: Stop 4.2, Soriano al Cimino to observe the lamproitelike shoshonitic lavas. Vico Volcano: Stop 4.3, caldera rim to observe leucite bearing rocks of the young volcanic cycle. Volsini volcanoes: Stop 4.4, Montefiascone centre to observe the products and the Bolsena Lake; Stop 4.5, Civita di Bagnoregio to observe the distal deposits of the Bolsena Volcanic Complex.

[5th day - Stop 5.1, Torre Alfina Volcano to observe lamproites and ultramafic xenoliths; Stop 5.2, Radicofani neck and the Tuscan shoshonite; Stop 5.3, Monte Amiata top, a trachytic volcano.

\section{Credits and permissions}

Front cover: Andy Warhol, 1985, "Vesuvius", acrylic painting on canvas, National Museum of Capodimonte (Naples). Reproduction on permission by Photo Library of the "Sovrintendenza Speciale" per il PSAE e il Polo Museale della città di Napoli, requested by the Geological Society of Italy on November 2014.

Figures 5 and 6 are used according to permission granted by the Periodico di Mineralogia (e.mail by Paolo Ballirano del 23 Agosto 2016). Figures 10 and 11 are used according to the "fair use" policy of the Geological Society of London (), and figure 15 is used under the "fair use" permission of the Geological Society of America ().

The use of the following figures has been permitted by the Copyright Clearence Center (RightLink): Figures of the box at pag 63 (licence \# 3943560183258), Fig. 33 (licence \# 3943551315531), Fig. 37 (licence \# 3966370289789), Fig. 38 (licence \# 3966371114994), Fig. 39 (licence \# 3966361033169), Fig. 43 (licence \# 3966361398828), Fig. 56 (licence \# 4072050341215), Fig. 61 (licence \# 3967141262037), Fig. 64 (licence \# 4071870177325).

Google Earth images are used according to the terms reported at the section "Uses in print" of the webpage. 


\section{Geological setting}

\section{The alkaline potassic rocks and the Central Mediterranean Region}

The alkaline-potassic magmatism in the Central Mediterranean area developed from Oligocene to present,

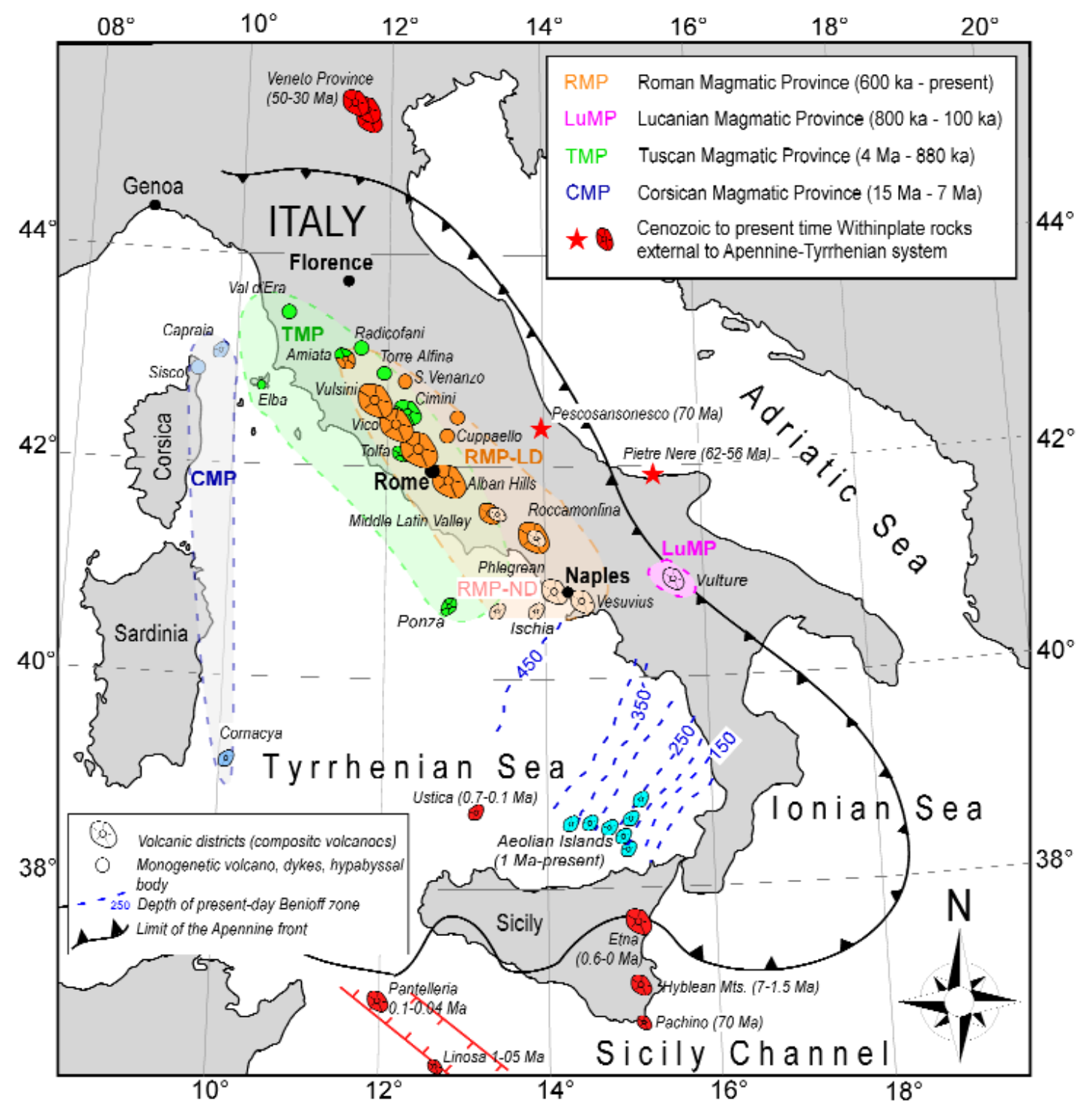
with the last eruption of leucite-bearing magmas occurring in 1944 AD at Vesuvius. A pioneering comprehensive study performed by Washington (1906) grouped the volcanic suites in three different magmatic regions on the basis of their mineralogical and petrographic characteristics: the Tuscan, the Roman and the Apulian regions. These magmatic regions were established with no temporal constraints. Despite of his detailed work, Washington (1906) did not report similar associations from Western Alps, Corsica, Tuscan Archipelago, and intra-Apennine area (Umbria). Washington (1906) used a local lithologic terminology e.g. vulsinite, ciminite, vicoite, italite, sommaite, etc.; these rock names no longer used in the international terminology (Le Maitre et al., 2002).

Recently, Avanzinelli et al. (2009) grouped the potassic and associated volcanic rocks of the Central Mediterranean area, by integrating the original

Fig. 1 - Distribution of ultrapotassic in Italy and their associated rocks in Central Mediterranean (from Conticelli et al., 2007, 2010a, 2011). 
division of Washington (1906) with the geochronological and genetic relationships, following the criteria suggested by Turner \& Verhoogen (1960). Thus a four-fold division of magmatic provinces has been proposed.

The Corsican Magmatic Province is the westernmost one, with few magmatic products belonging to volcanic suites ranging from leucite-free ultrapotassic (Fig. 2) to high-K calc-alkaline of Mio-Pliocene age (Fig. 1).

During Pliocene the volcanism migrated eastward to form the Tuscan Magmatic Province, which developed inland during the Pleistocene. Due to migration of

Leucite-free

Silica-saturated
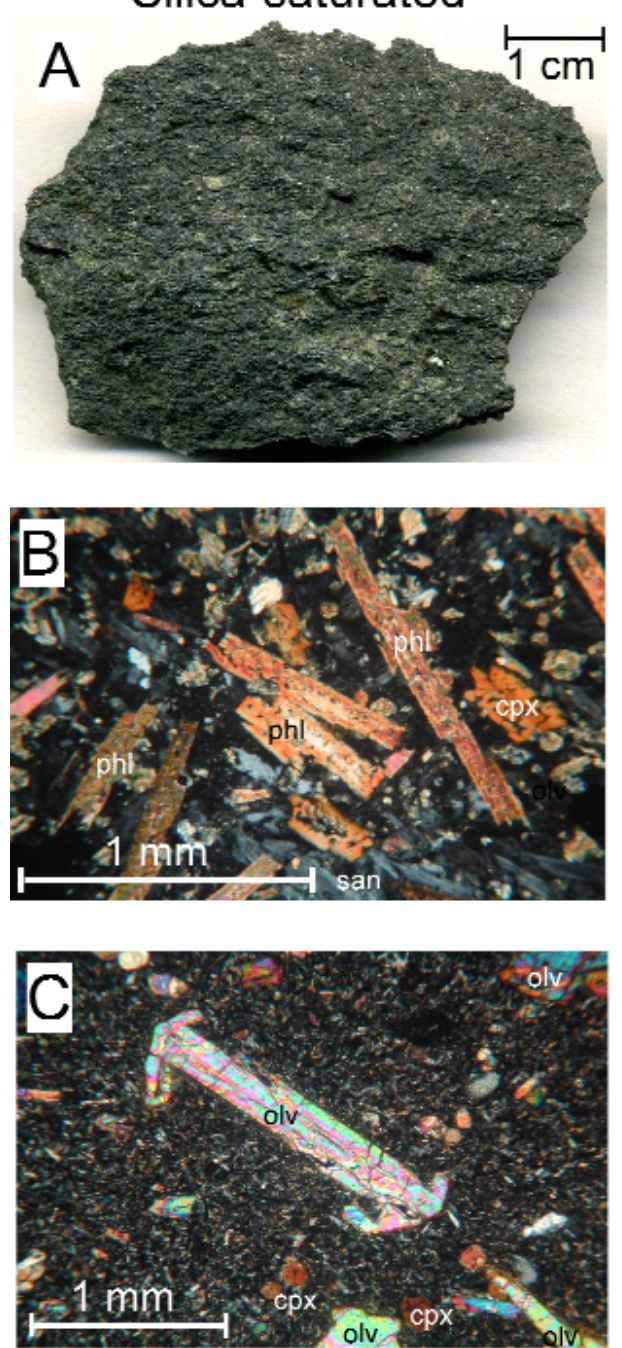

Leucite- bearing Silica-undersaturated
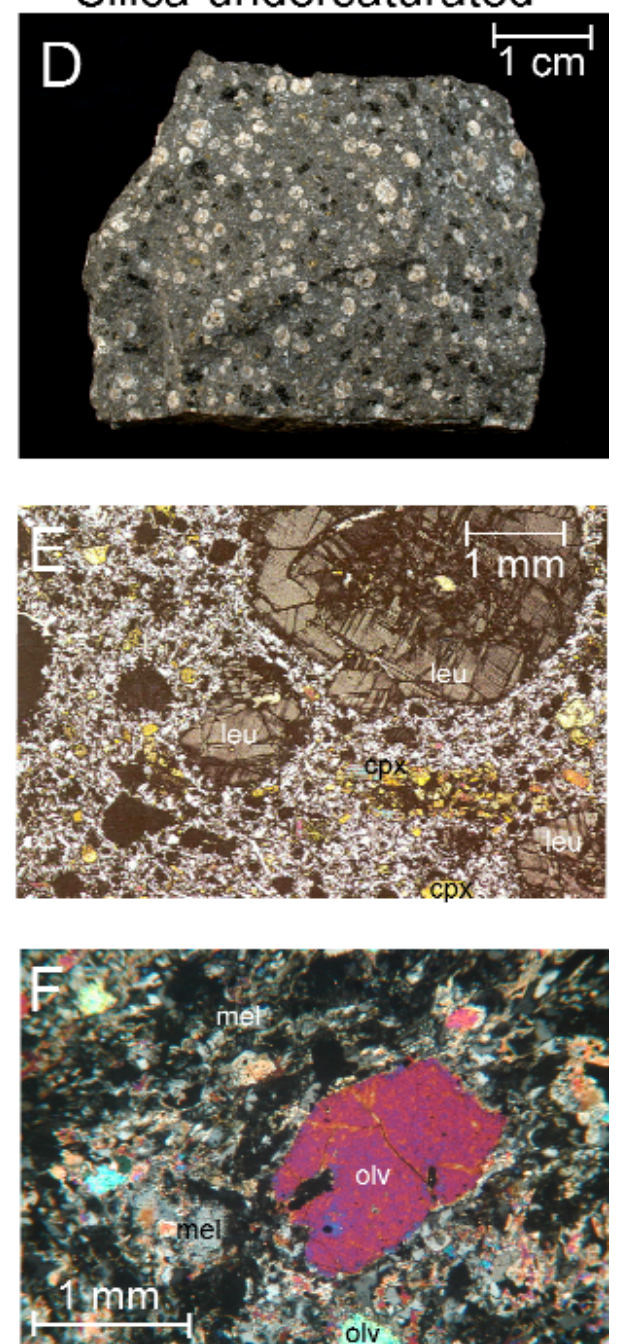
magmatic activity the mantle-derived igneous rocks of the Tuscan Magmatic Province are distributed on both sides of the western shoreline of the Italian peninsula (Fig. 1). Ultrapotassic rocks of both Corsican and Tuscan Magmatic Provinces are leucite-free (lamproite-like), which are associated with coeval to slightly younger shoshonitic and calc-alkaline volcanic suites (e.g., Peccerillo et al., 1987; Conticelli \& Peccerillo, 1990; Conticelli et al., 1992, 1997, 2004, 2007, 2009a, 2010a,b, 2011, 2012, 2013, 2015a,b; Conticelli, 1998; Peccerillo, 1999, 2005a; Perini et al., 2000).

Fig. 2 - Petrographic features of Italian ultrapotassic igneous rocks: A) Leucite-free lamproite from Sisco (Corsican Magmatic Province); B) microphotograph in thin section of a lamproite-like rock (orendite) from Orciatico (Tuscan Magmatic Province) with phlogopite and sanidine as major potassium mineral phases; C) microphotograph in thin section of a lamproite-like rock from Torre Alfina; D) Leucite-bearing rock from Vico Volcano (Roman Magmatic Province); E) leucite-bearing phonolite from Acquapendente (Vulsinian volcanoes, Latian districts); F) Melilitebearing foidite from San Venanzo (autoc. venanzite; Roman Magmatic Province, Umbrian district). 


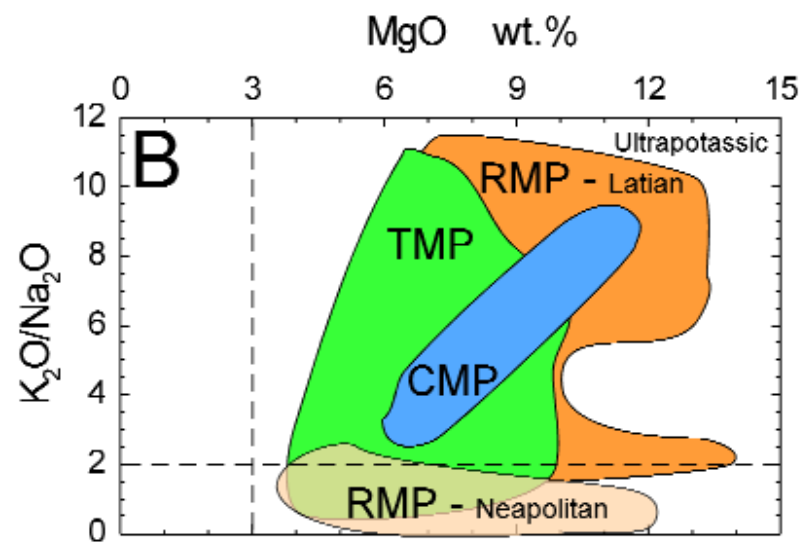

Plotted only samples with $\mathrm{Mg} \#=\frac{[\mathrm{MgO}]}{[\mathrm{MgO}]+\left[\mathrm{FeO}_{\mid 00}\right]}>0.60$ and $\mathrm{MgO}>4$ wt.\%

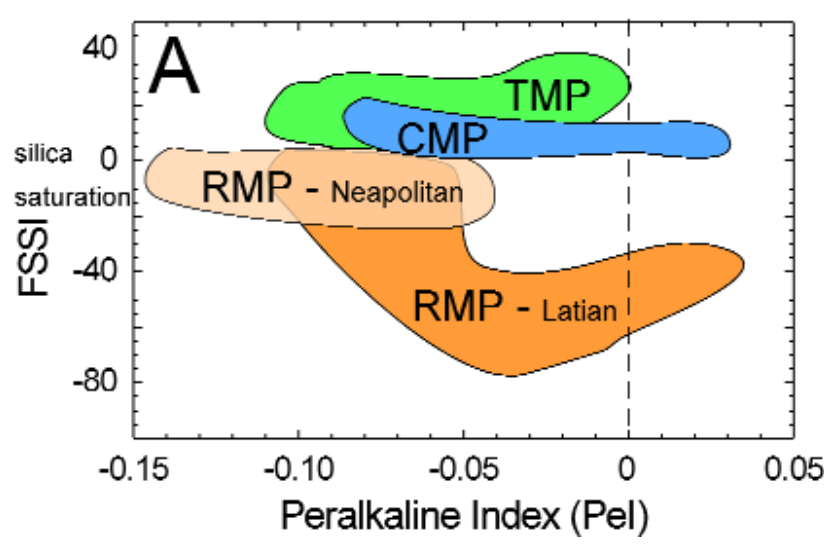

Fig. 3 - A) Feldspathoid SilicaSaturation Index (FSSI) vs. Peralkaline Index (PeI) for Italian mafic potassic rocks (after Frost \& Frost, 2008). FSSI $=\mathrm{q}-[\mathrm{lc}+2 *(\mathrm{ne}+\mathrm{kp})]$ normative, whilst Peralkaline Index $(\mathrm{PeI})=[(\mathrm{K}+\mathrm{Na})-\mathrm{Al}]$ molecular. B) $\mathrm{K}_{2} \mathrm{O} / \mathrm{Na}_{2} \mathrm{O}$ vs. $\mathrm{MgO}$ wt. $\%$ used for discriminating between mafic potassic and ultrapotassic Central Mediterranean rocks (Foley et al., 1987).
Further southeastward migration of volcanism during Pleistocene led to the emplacement of silica-undersaturated, leucite-bearing ultrapotassic rocks of the Roman Magmatic Province (Figs 2, 3), which in some cases are associated with younger shoshonitic to calc-alkaline volcanic suites (e.g., Conticelli et al., 1991, 2002, 2009b, 2010a; Peccerillo, 2005a; Boari \& Conticelli, 2007; Frezzotti et al., 2007; Avanzinelli et al., 2009; Boari et al., $2009 a, b)$. The volcanic activity of the Roman Magmatic Province pierced the boundary with the Holocene in its southernmost district, in the Neapolitan area, with a cluster of four volcanoes with historical volcanic activity (i.e., Ischia, Procida, Campi Flegrei and Vesuvius volcanoes; Peccerillo, 2005, and references therein).

The Lucanian Magmatic Province is the easternmost volcanic area (Fig. 1) with the association of Pliocenic haüyne- to leucite-bearing ultrapotassic rocks (e.g., Peccerillo, 2005a and references therein; De Astis et al., 2006; Avanzinelli et al., 2008). Carbonatitic lava has also been recorded in the activity of the Monticchio Volcano, during the final stages of the Lucanian Magmatic Province (e.g. D'Orazio et al., 2007, 2008; Stoppa et al., 2008).

\section{The volcanic suites}

Ultrapotassic rocks are defined using chemical parameters after Carmichael (1967) and Foley et al. (1987). A volcanic rock is considered ultrapotassic when it has $\mathrm{K}_{2} \mathrm{O}>3$ wt. \% concomitantly to $\mathrm{K}_{2} \mathrm{O} / \mathrm{Na}_{2} \mathrm{O}$ (wt.\%) $\geq 2$ (Le Maitre et al., 2002). As a general rule, however, mineralogical classification of potassic and ultrapotassic rocks is complex and in the past produced a plethora of rock names in part due to heteromorphism (Yoder, 1986). To avoid this problem and to provide unequivocal classification, Foley et al. (1987) suggested a chemical division into three different clans on the basis of chemical parameters: the lamproite, kamafugite, and Roman (plagioclase-leucititic) clans (Fig. 4). 
In Italy ultrapotassic rocks are associated in time and space with calcalkaline lamprophyres, shoshonitic and high-K calc-alkaline volcanic rocks, and at Monticchio monogenetic field, within the Lucanian Magmatic Province, with carbonatite-like rocks (Avanzinelli et al., 2009; Conticelli et al., 2010a, 2015a).

Lamproite-like rocks are Mg-rich alkaline ultrapotassic volcanic to hypabyssal terms (Foley \& Venturelli, 1989) characterised, compared to basalt they have lower $\mathrm{Al}_{2} \mathrm{O}_{3}$, FeOTot, $\mathrm{CaO}$ and $\mathrm{Na}_{2} \mathrm{O}$ and extremely high $\mathrm{MgO}$ and variable silica contents (Foley et al., 1987). Lamproite-like rocks are invariably plagioclase-free, with forsteritic olivine, chromian spinel, Alpoor clinopyroxene, K-richterite, sanidine, and apatite; leucite may be present in silica-undersaturated lamproite-like rocks, which are missing in lamproite-like rocks from the Central Mediterranean (i.e., Corsica and Tuscany, Conticelli et al., 2010a).

The kamafugite-like rocks are kalsilite-bearing melilitites (e.g., Holmes \& Harwood, 1932; Sahama, 1974; Gallo et al., 1984; Peccerillo et al., 1988). Because of their extreme mineralogical variability the rocks were named from the locality of first discover. However, heteromorphism also occurs as in the lamproites (Yoder, 1986) but Sahama (1974) suggested keeping the old names (i.e., katungite, mafurite, ugandite) for each rock,

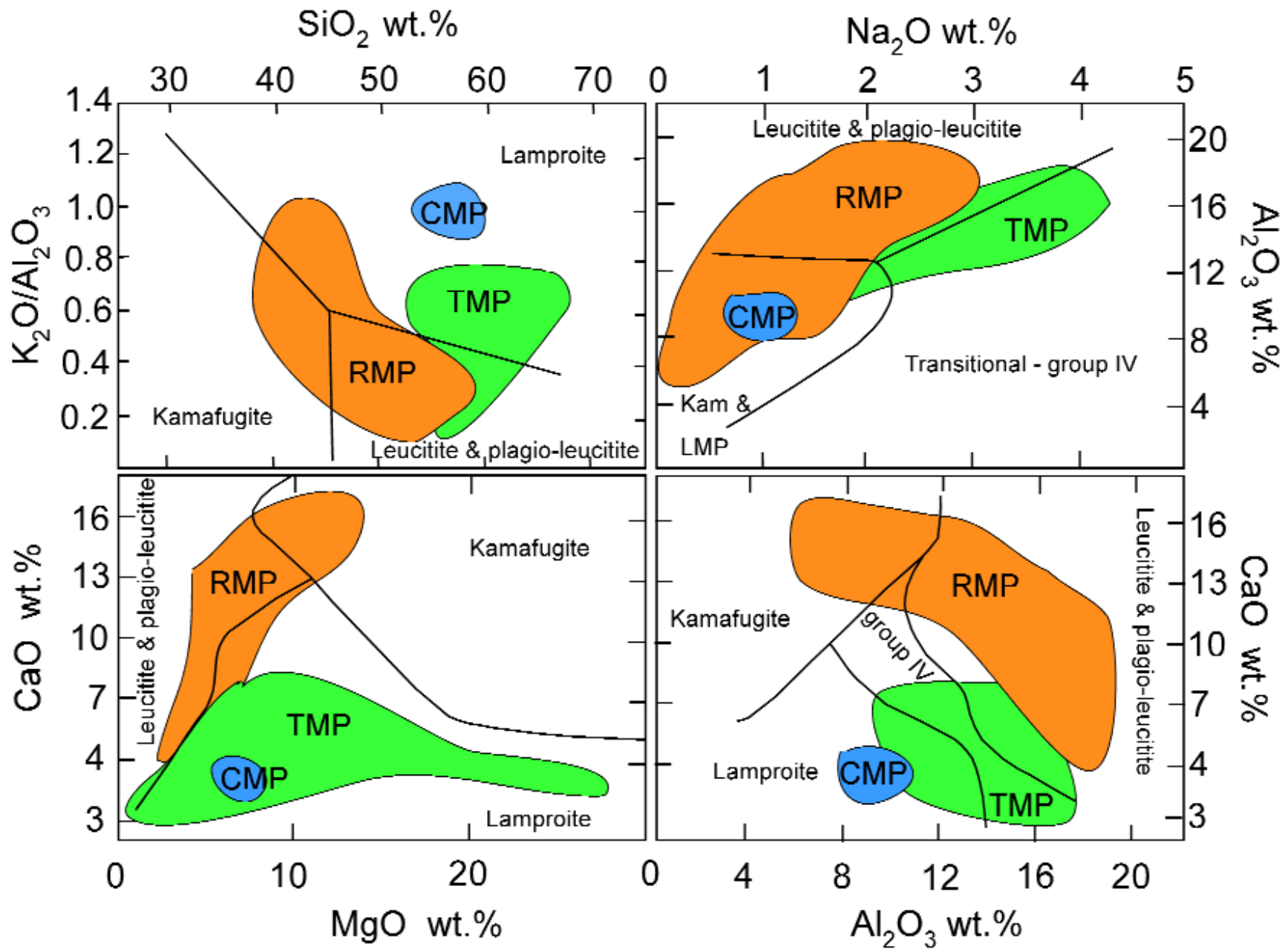

Fig. 4 - Chemical classification of Ultrapotassic volcanic rocks (redrawn after Foley et al., 1987) with reported the fields for Italian ultrapotassic igneous rocks. 
and combine them in a unique clan with a root name as an acronym of the African members: Katungite Mafurite - Ugandite. Kamafugite-like rocks are ultrapotassic but strongly silica and alumina undersaturated. According to Foley et al. (1987) kamafugite-like rocks are Mg-rich, alkaline, ultrapotassic volcanic rocks characterised by relatively low $\mathrm{SiO}_{2}, \mathrm{Al}_{2} \mathrm{O}_{3}$ and $\mathrm{FeO}_{\text {Tot }}$ but extremely high $\mathrm{CaO}$ and $\mathrm{Na}_{2} \mathrm{O}$ contents. Also, kamafugite-like rocks are feldspar-free, and dominated by kalsilite, nepheline, and sometimes leucite, with olivine, clinopyroxene, phlogopite, and melilite as the main mafic phases (Sahama, 1952, 1960; Gragnani, 1972; Yoder 1973, 1979; Cundari \& Ferguson, 1991; Conticelli \& Peccerillo, 1992).

The Roman-type rocks are leucite-bearing silica undersaturated and ultrapotassic (Fig. 3). A plethora of names has been used for this group of rocks, based on their type locality (e.g., vulsinite, ciminite, cecilite, vicoite, italite, Washington, 1906). Le Maitre et al. (2002) suggested a classification based on mineralogical and chemical parameters (Total Alkali Silica), thus basanite, tephrite, phonolitic tephrite, tephritic phonolite, and phonolite are the basic names modified with the leucite prefix, with leucitites among foidites (Conticelli et al., 2004, 2010a, 2015a; Peccerillo, 2005). All these rocks can be classified under groups names either leucitite or plagio(clase)-leucitite on the basis of the occurrence of modal plagioclase (Foley, 1992a). According to the definition of Foley et al. (1987) the leucitite and plagio(clase)-leucitite groups (i.e., Roman rocks) are made up of alkaline ultrapotassic volcanic rocks characterised by widely variable $\mathrm{MgO}$, with relatively low $\mathrm{SiO}_{2}$, and FeOTot, but relatively high $\mathrm{CaO}, \mathrm{Al}_{2} \mathrm{O}_{3}$, and $\mathrm{Na}_{2} \mathrm{O}$ contents (Fig. 2; Table 1). Leucite is ubiquitously present with plagioclase missing only in the most silica-undersaturated varieties. Olivine and high-Al clinopyroxene, leucite, and plagioclase, when present, are among the most abundant phenocrysts set in microcrystalline to cryptocrystalline groundmasses. Sanidine occurs as a phenocryst in the most differentiated varieties (Conticelli et al., 1987, 1991, 1997, 2010b; Perini \& Conticelli, 2002; Boari \& Conticelli, 2007).

The haüyne-bearing rocks are extremely silica undersaturated volcanic rocks characterised by high levels of both $\mathrm{K}_{2} \mathrm{O}$ and $\mathrm{Na}_{2} \mathrm{O}$ (De Fino et al., 1987; Beccaluva et al., 2002). Haüyne is also found as a phenocryst along with leucite and rarely nepheline (Melluso et al., 1996). These rocks are confined to the Lucanian Magmatic Province. They are found associated to melilite-bearing rocks and alvikite (Jones et al., 2000; D'Orazio et al., 2007).

All rocks with approximately 50 vol. \% of carbonate minerals can be classified as carbonatite. CalciumMagnesium- and Iron-carbonatite are divided on the basis of the main carbonate phase in the mode of the rock; namely calcite, dolomite, ankerite. Alvikite is a silica-rich calcium-carbonatite distinguished by Sövite on the basis of trace element content (Le Bas, 1999). There has been debate over the occurrence of primary 
carbonatites in Italy. Stoppa \& Woolley (1997) reviewed possible occurrences of carbonatites in Italy including also some rocks thought to be pyrometamorphic rocks due to either natural or anthropogenic combustion of marly sedimentary rocks (e.g., Stoppa, 1988; Melluso et al., 2003, 2005a, 2005b; Capitanio et al. 2004; Stoppa et al., 2005), in other cases some of them have been questioned as the result of carbonate syntexis resulting in a dilution of major and trace element contents, but not of CaO (Peccerillo 1998; Peccerillo, 2004, 2005b; Woolley et al., 2005). Unquestioned mantle-derived alvikitic rocks have been documented at Monticchio monogenetic field (e.g., Jones et al., 2000; D'Orazio et al., 2007).

The shoshonitic series (Peccerillo \& Taylor, 1976) is a magmatic sequence of volcanic rocks mildly enriched in potassium, with variably silica saturated varieties in the most evolved rocks. The rock types range from potassic trachybasalt (shoshonitic basalt) to trachyte, through shoshonite s.s. to latite. These rocks have variable enrichment in $\mathrm{K}_{2} \mathrm{O}$. No definitive boundary between ultrapotassic groups and shoshonitic series has been drawn on the $\mathrm{K}_{2} \mathrm{O}$ vs. silica diagram (Peccerillo \& Taylor, 1976); in some cases shoshonites are classified as ultrapotassic rocks (e.g., Conticelli et al., 2010b, 2011, 2015a) and they fall within the field of transitional group IV ultrapotassic rocks (Fig. 2) according to the classification scheme of Foley et al. (1987). In Italy this group of rocks was originally recognised by Appleton (1972) at Roccamonfina Volcano, distinguishing them as a low potassium series (LKS) from the high potassium series (HKS) represented by older leucitites and plagioleucitites. Later Civetta et al. (1981) renamed them as potassic series (KS) keeping the Appleton's (1972) name for the leucite-bearing terms. Conticelli \& Peccerillo (1992) interpreted the rocks belonging to this series as transitional (TRANS) from ultrapotassic series to calc-alkaline series. Conticelli et al. (2004) preferred the use of shoshonite the official names provided by IUGS (Le Maitre et al., 2002).

The high-K calc-alkaline and calc-alkaline series are defined on the basis of $\mathrm{K}_{2} \mathrm{O}$ contents with respect to silica (Peccerillo \& Taylor, 1976). They also match the chemical and mineralogical parameters provided by Arculus (2003). They are sub-alkaline rocks ranging from basalt to rhyolite, through basaltic andesite, andesite, and dacite (Le Maitre et al., 2002). The pre-fix high-K is added when needed according to the Peccerillo \& Taylor's (1976) scheme. These rocks are more represented within the ultrapotassic association of the Italian peninsula than previously though (Di Girolamo et al., 1976; Perini et al., 2000; Conticelli et al., 2004, 2009a,b, 2010a, 2011, 2015b; Boari \& Conticelli, 2007; Frezzotti et al., 2007; Boari et al., 2009a). 


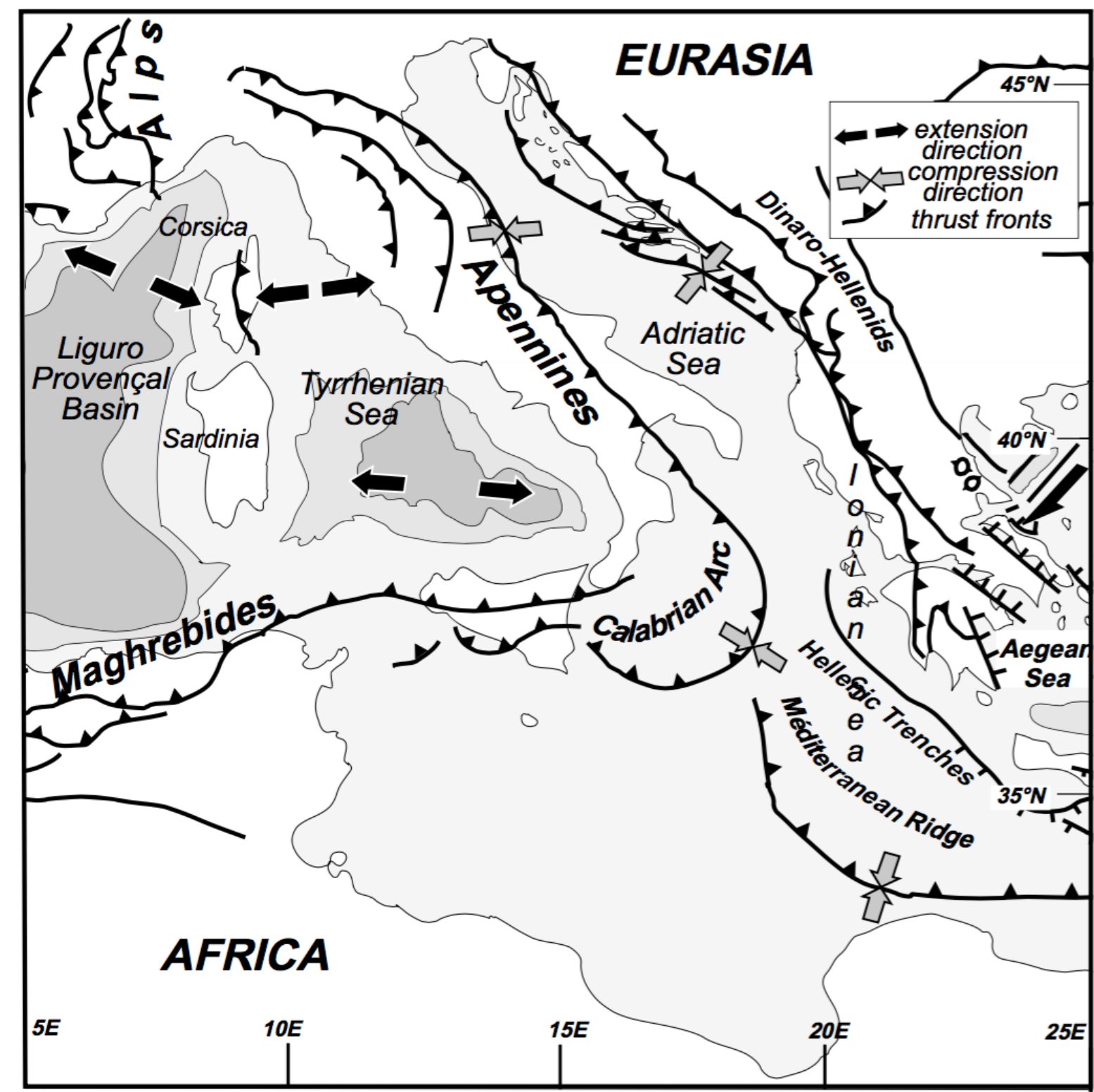

Fig. 5 - Geologic sketch map of the Central Mediterranean with reported the main arcuate orogenic belts (Apennine Maghrebide belt) and extensional back-arc basins (Liguro-Provençal and Tyrrhenian basins). From Mattei et al. (2004).

\section{The Geodynamic framework}

The present-day structure of the Central Mediterranean region derives from the convergence of Africa and Eurasia (Fig. 4), which over the Tertiary occurred at average $1-2 \mathrm{~cm} / \mathrm{yr}$, with a total of about $400-500 \mathrm{~km}$ (Dewey et al., 1989). During this time, the Ionian-Adriatic lithosphere continuously subducted westward and northwest underneath the Eurasia plate. This process led to the progressive closure of the intervening Mesozoic oceanic basins of the Tethyan domain, and formation of a complex arcuate orogenic belt (ApennineMaghrebide belt) and extensional back-arc basins (Liguro-Provençal and Tyrrhenian basin, Fig. 5; Dewey et al., 1989; Horvath \& Berckheimer, 1982). The subducting slab is still recognizible beneath the Calabrian arc, where deep seismicity is detected along a narrow ( $200 \mathrm{~km}$ ) and steep $\left(70^{\circ}\right)$ Benioff zone dipping north-westward down to about $500 \mathrm{~km}$. Continental collision is probably still active in the central-northern Apennines, where intermediate earthquakes occur down to $90 \mathrm{~km}$ (Selvaggi \& Amato, 1992; Carminati et al., 2005).

The convergence of Africa and Eurasia and the related subduction of the Ionian- 
Adriatic lithosphere resulted in the building of the Alpine-Apennine belts. The main geological evidence of this convergence is the deposition of thick siliciclastic deposits in the foredeep basins and the HP/LT metamorphism in the internal part of the orogenic wedge (Jolivet et al., 1998). The migration of the Apennine orogenic front is marked by the deposition ages of siliciclastic deposits. The onset of siliciclastic deposition occurred in northern Apennine during the Late Cretaceous in the Ligurian oceanic domain. These deposita were deformed during the Late Cretaceous to Early Eocene, forming a double vergent accretionary wedge that outcrops from Corsica Island to the Italian peninsula (Treves, 1984; Carmignani et al., 1994). From the Oligocene onwards, foredeep basins migrated eastward on the top of continental crust, adjacent to the passive margin of Apulia. Incorporation of these basins into the Apenninic orogenic wedge marked the subduction of Adriatic continental lithosphere underneath Europe. During the Neogene, the foredeep basins further migrated toward the Apulia foreland ahead of the eastward migrating orogenic front. Foredeep basins formed on top of progressively more external units, with an eastward migration to the Adriatic foreland during the Quaternary, where the foredeep deposition ceased (Cipollari \& Cosentino, 1995, and references therein). During the Quaternary the southeastward rollback of the subducting Ionian plate was expressed in the southern Apennines by progressive southeastward shifting (parallel to the longitudinal axis of the chain) of the Bradanic foredeep basin (Tropeano et al., 2002, and references therein) and of the Apenninic outer thrust front, which is presently located offshore, in the Ionian Sea (Doglioni et al., 1999 and references therein).

In the central-western Mediterranean, differential trench retreat of the Ionian-Adriatic slab caused the formation of the Liguro-Provençal and Tyrrhenian back arc basins (Malinverno \& Ryan, 1986; Lonergan \& White, 1997; Faccenna et al., 2001; 2004). The Liguro-Provençal spreading took place simultaneously with the eastward drift of the Corsica-Sardinia block, which rotated counter-clockwise about a pole located north of Corsica (e.g., Van der Voo, 1993; Speranza et al., 2002 and references therein). Rifting and drifting processes in the Corsica-Sardinia were related to the southeastward retreat of the subducting Ionian slab, and were accompanied by arc-related volcanism, which appeared first in Sardinia ( $32 \mathrm{My})$ and in Provençe and continued until 14 My in southwestern Sardinia (i.e., Beccaluva et al., 1985, 2013; Lustrino et al., 2004). After the end of the Corsica-Sardinia drifting, back-arc extension continued in the southern Tyrrhenian Sea. In this basin, oceanic crust formed diachronously in two sub-basins: between 4.3 and 2.6 Ma the Vavilov basin was formed, whereas the Marsili basin developed after <2 Ma (Marani \& Trua, 2002; Nicolosi et al., 2006). Seismic, structural and stratigraphic data on the on-shore western Calabria-Peloritani terrane (Mascle et al., 
1988; Mattei et al., 2002) suggest that rifting started along the western margin of the southern Tyrrhenian Sea (Sardinian margin) during Serravallian, and progressively migrated south-eastward in the Vavilov (late Messinian-Early Pliocene) and Marsili (Late Pliocene-Early Pleistocene) basins. In the northern Tyrrhenian Sea lithospheric extension caused the formation of Neogene sedimentary basins. N-S to NW-SE oriented extensional basins developed on the previously thickened Alpine crust in the hinterland, contemporary with flexural basins in the foreland (e.g., Kastens et al., 1988), which get younger eastward as well documented by the age of the infilling sedimentary sequences. In the westernmost Tyrrhenian sea these sedimentary sequences are Lower Miocene in age and are characterized by N-S trending east-dipping normal faults (Bartole, 1995) while they are Pleistocene in age in the Umbrian region, where extensional tectonics is presently active and most of the normal faults strike NW-SE and dip westward (Jolivet et al., 1998; Collettini et al., 2006).

\section{Present day tectonics and kinematics}

Satellite geodesy investigations, the distribution of seismicity, geological, structural and paleomagnetic data provide a framework for the recent tectonic evolution of Italian geodynamics, which is substantially different from that active during the Neogene and Pleistocene (until about $1 \mathrm{Ma}$ ). Subduction and backarc spreading are no longer active (D'Agostino \& Selvaggi, 2004; Goes et al., 2004; Mattei et al., 2007).

The GPS data show that in Italy the current convergence between Eurasia and Nubia (the African plate with the exception of the region east of the East African Rift) is about 5-6 mm/year and oriented NW (Fig. 6)(Sella et al., 2002; D'Agostino \& Selvaggi, 2004; Mattei et al., 2004). The study of earthquakes and tectonics, however, has recently suggested that the manner in which this convergence is absorbed along the margin between the two plates is extremely complex, given the coexistence of compressive and extensional deformation along a wide area stretching from North Africa to Greece, and affecting also the entire Italian peninsula (McKenzie, 1972; Goes et al., 2004). The existence of areas with low or no seismicity has suggested the possible presence of kinematically independent microplates between Eurasia and Africa. In particular, the distribution of earthquakes (Anderson \& Jackson, 1987) and recent geodetic data (Ward, 1994; D'Agostino and Selvaggi, 2004; Goes et al., 2004) show that the Adriatic region currently moves to NE respect to Eurasia, and it has an independent motion relative to both the Nubia and European plates (Fig. 6). 


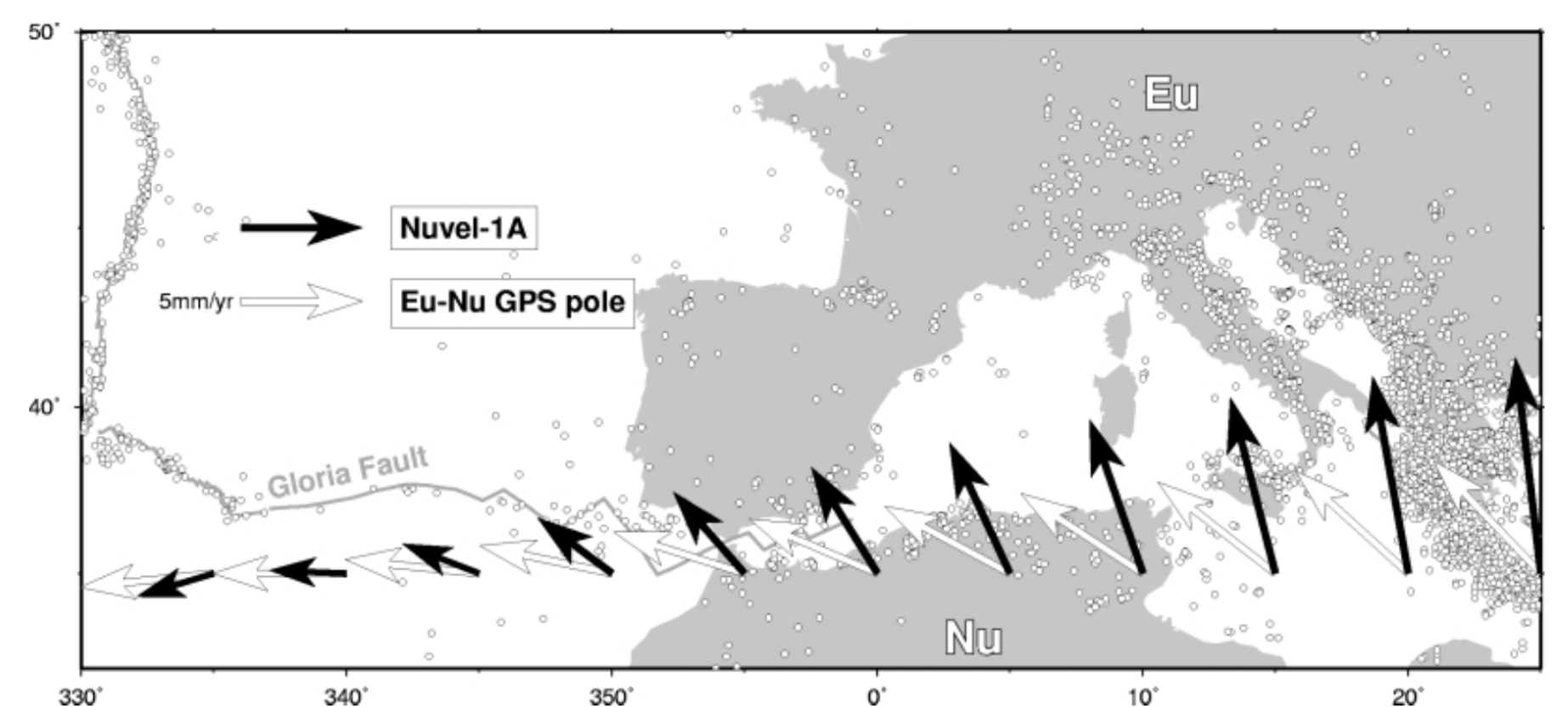

Fig. 6 - Convergence vector velocities predicted by the Nuvel-1A model and the REVEL GPS pole of rotation (Sella et al., 2002; D'Agostino \& Selvaggi, 2004). A significantly different convergence direction and magnitude are predicted by the two models in the Central Mediterranean suggesting a recent change in the kinematic conditions. Small circles are crustal earthquakes (depth $<50 \mathrm{~km}$ ) with $M>4$ occurred in the interval 1980-2003 from the USGS/NEIC catalogue (http://neic.usgs.gov/neis).

From Mattei et al., 2004.

These results are consistent with geological and paleo-magnetic data, which show a gradual deactivation of the compressional outer fronts of the Apennines and Sicily, the gradual decrease of the subduction processes in the Italian region and the end of the curvature processes of the Northern Apennines and the Calabrian Arc (Mattei et al., 2004; Cifelli et al., 2007; Mattei et al., 2007).

These data suggest that the convergence between Africa and Eurasia is currently absorbed by the motion of the Adriatic microplate, rather than by subduction of Adriatic-Ionian lithosphere (Fig. 7). At the same time geodetic data show that the Adriatic area is kinematically independent from the Apennine area, which shows velocity vectors oriented NNW respect to Eurasia, supporting the existence of active deformation in the axis of the chain already highlighted by the study of seismicity and geological analysis (e.g., Valensise \& Pantosti, 2001). Studies of deformation based on geodetic triangulation show that the Apennine region is currently subject to an extension rate of about 3-5 mm/year NE-SW oriented (Hunstad et al., 2003), which is consistent with the focal mechanisms and the distribution of the major historical and instrumental earthquakes. 


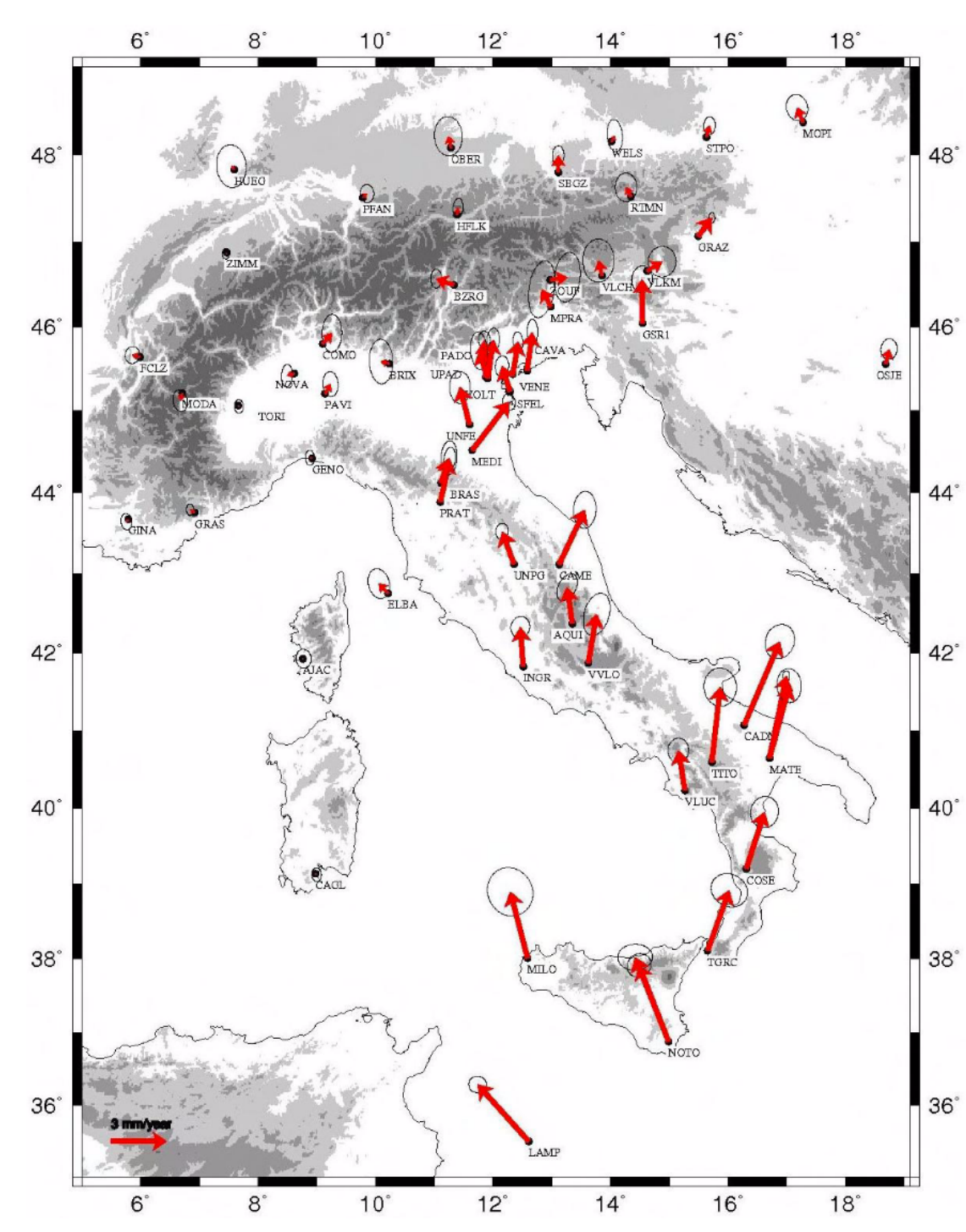

Fig. 7 - GPS velocities relative to Eurasia of continuous stations in Italy. Velocities relative to Eurasia defined from continuous GPS stations. Error ellipse represents the 95\% confidence interval (redrawn after D’Agostino \& Selvaggi, 2004; Mattei et al., 2008; Conticelli et al., 2010a).
D'Agostino et al. (2008), on the base of GPS observations and earthquake slip vectors, suggest that the kinematics of the Adriatic region is controlled by the presence of two microplates: Adria (corresponding with the northern Adriatic region) and Apulia (corresponding with the southern Adriatic, Ionian and Hyblean regions). The opposite rotations (counterclockwise for Adria and clockwise for Apulia) of these two microplates respect to Europe are able to explain the present-day deformation pattern in the central Adriatic region and represent the way in which the relative motion between Nubia and Eurasia is presently accommodated in the Central Mediterranean region.

\section{Structural and geological features of the extensional Tyrrhenian margin}

In the westernmost Northern Tyrrhenian Sea, where the Western Tyrrhenian (Corsican) Magmatic Province occurs (Fig. 1 ), the sedimentary sequences that infill the extensional sedimentary basins are Lower Miocene in age and are bounded by N-S trending, east-dipping normal faults (Bartole, 1995), whilst in the Apennine region they are Pleistocenic, and extension is presently active and most of the normal faults strike NW-SE.

In the Central Tyrrhenian margin, the onset of extensional tectonics can be dated at the Late Miocene because syn-rift sedimentary sequences have been recognised in extensional basins located between the Tolfa-Cerite-Manziana and Roccamonfina volcanoes (Figs 1, 4). In the Southern Tyrrhenian 
margin, south of the Roccamonfina area, extensional tectonics started more recently, with a similar eastward temporal migration. In this region the onset of the extension is marked by Late Pliocene syn-rift sedimentary marine deposits that crop out along the Tyrrhenian coast of the Neapolitan region. Extension later progressed toward the axis of the Apennine chain, where sedimentary basins are filled by lower-middle Pleistocene continental sequences (Cinque et al., 1993), and the largest ( $M>6.7$ ) historical and instrumental seismicity ever recorded occurred.

In Northern Apennines extensional tectonics is mostly controlled by NW-SE oriented, east-dipping low-angle normal faults and associated high-angle east-dipping normal faults. Low-angle normal faults gently dipping eastward, show evidence of present-day activity along the axial part of the Apennine chain, whereas their older equivalents now outcrop along the western part of the margin. Here, exhumed normal faults have been widely recognized in the Alpine metamorphic units in the Elba and Giglio Island, offshore Tuscany (Jolivet et al., 1998; Collettini et al., 2006).

Toward the south, the existence of low-angle normal faults is less evident and active extension is mainly given by high-angle normal faults, NW-SE oriented. In the Central Apennines, high-angle active normal faults dipping westward. Such faults show long-term activity, which is responsible for the formation of large intermontane extensional basins, infilled by Late Pliocene-Quaternary continental sedimentary sequences (D'Agostino et al., 2001). High-angle NW-SE oriented, west dipping, normal faults are especially evident along the axis of the Apennine chain. Conversely, toward the west normal faults are covered by Quaternary volcanic deposits and their existence has been recognized by means of geophysical investigations and deep boreholes drilled for geothermal research (Barberi et al., 1994).

In the Southern Apennines, the active normal faults are at a high-angle and oriented NW-SE dip either eastward or westward. Field observations and seismological data show that the Irpinia 1981 M = 6.5 earthquake occurred along a NW-SE oriented east-dipping normal fault (Westaway \& Jackson, 1984; Pantosti et al., 1993), whereas, some of the most important intermontane Quaternary extensional basins are bounded by NW-SE west dipping oriented normal faults.

All along the extensional Tyrrhenian margin an important role is exerted by transverse tectonic structures, NE-SW oriented, which either bound some of the major extensional sedimentary basins in the area, or represent the tectonic elements along which the main segments of the NW-SE oriented normal faults reverse their dip directions (Faccenna et al., 1994; Acocella \& Funiciello 2006; Barchi et al., 2007). In some cases NE-SW oriented faults also bound major 
NE-SW oriented extensional sedimentary basins (i.e., Baccinello-Cana, Cerite, Ardea, Garigliano), which formed parallel to the main, NE-SW oriented, stretching direction and play a major role in transfering extension to the different segments of the NW-SE oriented normal faults. The NE-SW normal fault system is particularly important along the western side of the extensional Tyrrhenian margin, whereas it is of minor importance within the axis of the Apennine chain, where extensional basins are NW-SE oriented. In particular, NE-SW tectonic lineaments control the location of Quaternary volcanoes all along the western Italian peninsula. Most of the Quaternary volcanoes formed where NW-SE normal faults intersect transverse tectonic lineaments, which represent a preferential structure for magma upwelling and fluid emissions (Funiciello \& Parotto, 1978; Acocella \& Funiciello, 2006).

Extensional tectonics along the Tyrrhenian margin of the Italian peninsula has produced significant crustal thinning, high heat flow, mantle fluid signatures, and a characteristic distribution of seismic activity. Crustal thickness has been recently defined in detail along a transect from Northern Corsica to the Adriatic Sea (Pialli et al., 1998; Collettini et al., 2006) using receiver functions from tele-seismic data (Piana Agostinetti et al., 2002; Di Bona et al., 2008). Results converge to show the upwelling of the Moho in the Tyrrhenian area, where Moho depth is about $22 \mathrm{~km}$, and a progressive westward thickening of the continental crust as far as the Apennine chain, with a maximum crustal thickness of about $35-38 \mathrm{~km}$ toward the Adriatic foreland. To the west, data indicate partial overlap between the deep Adriatic Moho and the shallower Tuscan Moho, with a mantle slice embedded between two crustal slices.

Heat flow is very high values all the Tyrrhenian border of the central-northern peninsula, from Tuscany to the Neapolitan area, but discontinuously distributed. Southern Tuscany and northern Latium have high heat flow $\left(>100 \mathrm{~mW} / \mathrm{m}^{2}\right)$, with localised peaks $\left(>600 \mathrm{~mW} / \mathrm{m}^{2}\right)$, which produce several geothermal fields, with the Larderello one being the most famous (Mongelli et al., 1991; Fig. 8). Toward the south-east, heat flow is drastically reduced within the Middle Latin Valley, the area between the Colli Albani and the Roccamonfina volcanoes, as a consequence of the presence of thick carbonate sedimentary sequences hosting huge karstic reservoirs that buffer heat flow to values lower than normal $\left(30 \mathrm{~mW} / \mathrm{m}^{2}\right)$.

It is also noteworthy that the presence of convective support to topography and strong attenuation of seismic waves consistently suggest that a positive thermal structure of the crust-mantle boundary is characteristic of a large region including the Apennine chain and its Tyrrhenian border from southern Tuscany to the Vulture area (Mele et al., 1997; D’Agostino \& McKenzie, 1999). 


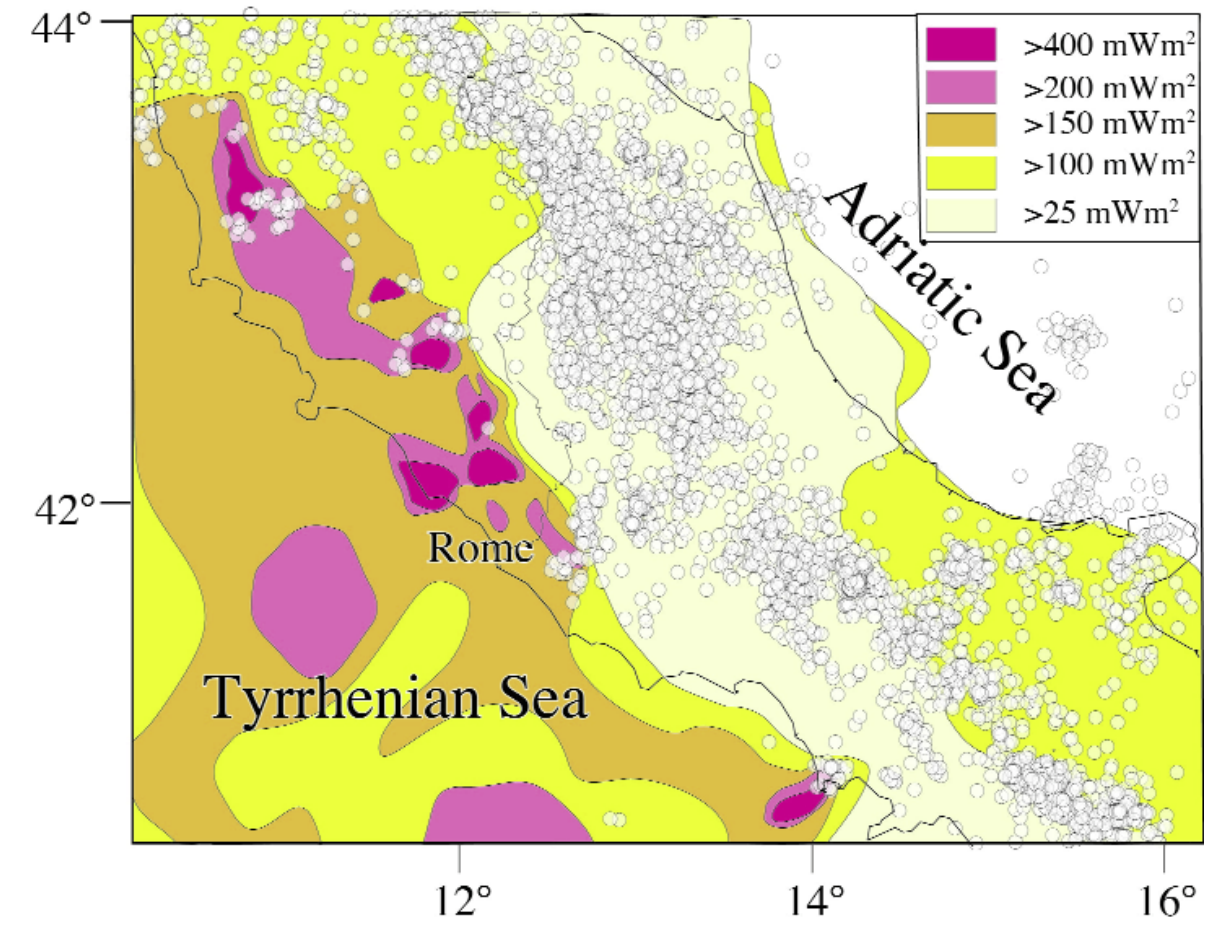

Fig. 8 - Heat flow and seismicity in Central Italy. Heat flow values are generally very high along the Central-Northern Tyrrhenian margin of the Italian peninsula (Mongelli et al., 1991). High values of heat flow correspond to a decrease in seismic activity, which is concentrated along very small areas corresponding to recent or active volcanoes or geothermal fields (from Conticelli et al., 2010a).
The extensional Tyrrhenian margin of the Apennine chain is the site of extensive $\mathrm{CO}_{2}$ degassing, mostly derived from a mantle source and representing a significant amount of the estimated global $\mathrm{CO}_{2}$ emitted from volcanoes (Collettini \& Barchi, 2002; Chiodini et al., 2004; Miller et al., 2004) which in some cases is related to Carbon recycling within the mantle (e.g., Frezzotti et al., 2009; Burton et al., 2013; Ammannati et al., 2016 and references therein).

The anomalous flux of $\mathrm{CO}_{2}$ decreases toward the axis of the Apennine chain. Here fluid overpressures, documented at depth by deep boreholes, suggest that $\mathrm{CO}_{2}$-rich fluids can be trapped by stratigraphic or structural seals and released to shallow reservoirs at hydrostatic fluid pressure, triggering the seismic events in the Apennine chain (Miller et al., 2004). Strong earthquakes have occurred along the axis of the Apennine chain, and represent the most important effect of active deformation in the Italian peninsula. In this region the extensional active stress field is NE-SW oriented, with extension rate of 2.5-3.0 mm/yr. Here, $M>6.5$ earthquakes cluster in the upper crust at depth between 5 and $12 \mathrm{~km}$ with extensional focal mechanisms, as shown by geodetic data (Hunstad et al., 2003) and borehole breakout results (Montone et al., 2004). Toward the Tyrrhenian margin seismicity decreases dramatically as heat flow increases. In this region, seismic activity is clustered at very shallow level and is mostly concentrated along the active volcanoes and geothermal fields of the area (Fig. 7). 


\section{Geochronology time of Italian Peninsula volcanism}

Krummenacher \& Evernden (1960) and Evernden \& Curtis (1965) reported the first pioneering K/Ar geochronological data on ultrapotassic rocks from Central-Southern Italy. Since then a large set of age data is available in scientific literature. Thise large data base, however, shows variable geological confidence due to variable accuracies and precisions shown by different laboratories that have performed the data, and sampling shows an uneven distribution on the various volcanic centers (e.g., Marra et al., 2004; Laurenzi, 2005 and references therein).

$\mathrm{K} / \mathrm{Ar}$ and ${ }^{40} \mathrm{Ar}-39 \mathrm{Ar}$ data constitute the bulk of the ages on the Italian ultrapotassic and associated igneous rocks. Other ages obtained by $\mathrm{Rb} / \mathrm{Sr}$, $\mathrm{U}$-Th disequilibrium, fission tracks are subordinate. ${ }^{14} \mathrm{C}$ dating is quite widespread on products younger than $50 \mathrm{kyr}$.

Technological progress has led to instrumental improvements that enable more precise analyses on very small samples, for conventional K/Ar and $40 \mathrm{Ar}-39 \mathrm{Ar}$ methods. Quite often published age data related to the same volcanic units disagree. This is particularly true for the older $\mathrm{K} / \mathrm{Ar}$ data.

There are many reasons for these discrepancies. K/Ar ages are in fact model ages, because an atmospheric initial isotopic ratio is assumed in their calculation, and if this is not the case the obtained "age" value is older than the true one. Other "wrong" ages likely derive from the use of altered mineral phases, as revealed by their non-stoichiometric $\mathrm{K}$ contents. A further possibility of biased younger $\mathrm{K} / \mathrm{Ar}$ ages is sor sanidines, which are difficult to melt completely (McDowell, 1983) leading to an underestimate of ${ }^{40} \mathrm{Ar}$ concentration. It is clear from the above consideration that ${ }^{40} \mathrm{Ar}-39 \mathrm{Ar}$ data, when available, will be preferred to $\mathrm{K} / \mathrm{Ar}$ data. In figure 5 the compilation of available data on igneous rocks of the Italian peninsula is used to show the succession of magmatic events, and then of the magmatic provinces, in Central Italy.

The earliest ultrapotassic event of lamproite-like activity, and associated shoshonitic and high-K calc-alkaline magmas (Fig. 9), took place in the Central Mediterranean during the Miocene along a narrow strip offshore from Ligurian basin to Cornacya, running along the eastern shores of the Sardinia-Corsica block (Fig. 1), defined Corsican Magmatic Province (Avanzinelli et al., 2009).

During the Pliocene, the magmatism migrated eastward in the Tuscan mainland, to give rise to the Tuscan Magmatic Province with the emplacement of scattered ultrapotassic magmatic rocks of lamproite-like ultrapotassic affinity associated in space and time with shoshonitic and high-K calc-alkaline rocks. This magmatic activity continued to the Early Pleistocene. 


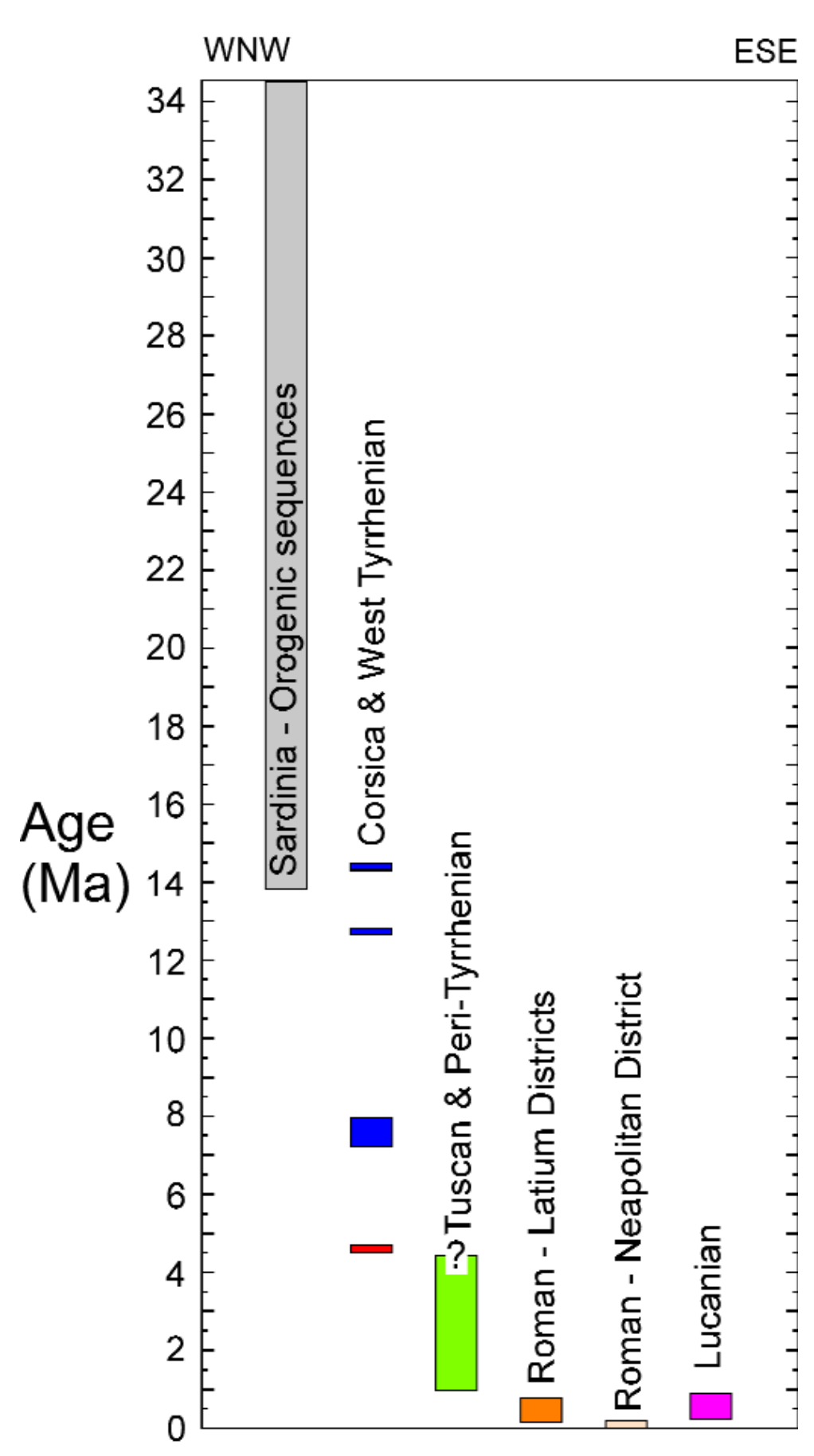

A very short time gap separates the Tuscan magmatic rocks from the younger leucititic products of the Roman Magmatic Province (Fig. 1 ). Indeed, the Roman province is characterised during the early phases of the magmatism (600-300 ka; Conticelli et al., 2010a, 2013, 2015a) by silica undersaturated ultrapotassic rocks dominated by leucite crystallisation with less sanidine and kalsilite. The Roman province shows a twofold age distribution with Latian volcanoes (districts) that ended their parossistic to lava emission at around $50 \mathrm{ka}$, whilst activity in the Neapolitan district (e.g., Somma-Vesuvius, Campi Flegrei, Procida and Ischia volcanoes) continued during the Holocene with last lava flow of 1944 AD.

Fig. 9 - Age distribution of ultrapotassic and related volcanic and subvolcanic rocks in Italy and surroundings (redrawn after Conticelli et al., 2010a). Age data are from the following papers: Evernden \& Curtiss (1965); Barberi et al. (1967, 1994); Borsi (1967); Borsi et al. (1967); Carraro \& Ferrara (1968); Nicoletti (1969); Hunziker (1974); Lombardi et al. (1974); Basilone \& Civetta (1975); Civetta et al. (1978); Bigazzi et al. (1981); Radicati et al. (1981); Cassignol \& Gillot (1982); Gillot et al. (1982); Metzeltin \& Vezzoli (1983); Pasquarè et al. (1983); Sollevanti (1983); Fornaseri (1985a,b); Laurenzi \& Villa (1985, 1987); Poli et al. (1987); Metrich et al. (1988); Savelli (1983, 1988); Ballini et al. (1989a, b); Villa et al. (1989, 1999); D'Orazio et al. (1991); Turbeville (1992); Cioni et al. (1993); Laurenzi et al. (1994, 2015); Laurenzi \& Deino (1996); Karner \& Renne (1998); Bellucci et al. (1999); Pappalardo et al. (1999); Brocchini et al. (2000, 2001); Giannetti \& De Casa (2000); Conticelli et al. (2001); De Vivo et al. (2001); Giannetti (2001); Karner et al. (2001a,b,c) ; Mascle et al. (2001); Marra et al. (2003, 2008); Rolandi et al. (2003); Deino et al. (2004); Cadoux et al. (2005); Freda et al. (2006); Florindo et al. (2007); Rouchon et al. (2008); Scaillet et al. (2008); Boari et al. (2009b); Cadoux \& Pinti (2009); Gasparon et al. (2009); Giaccio et al. (2009); Sottili et al. (2010); Lustrino et al. (2013) and references therein; Conte et al. (2016). 
In addition the Roman Province is characterised by larger magma volumes that built large stratovolcanoes. These are clustered in districts apparently at regular distance one from the other one (Mattei et al., 2010). The mean spacing of the volcanic districts, measured along the main 328-km-long NW-trending volcanic belt, is $41 \mathrm{~km}$ (Fig. 10). Among these volcanoes, however, the only one not showing silica-undersaturated leucititic rocks is the Monte Amiata Volcano, which probably was generated by hybrid magmas due to mixing between Tuscan and Roman end members (Conticelli et al., 2010a, 2015b, Marroni et al., 2015).

\section{NW}

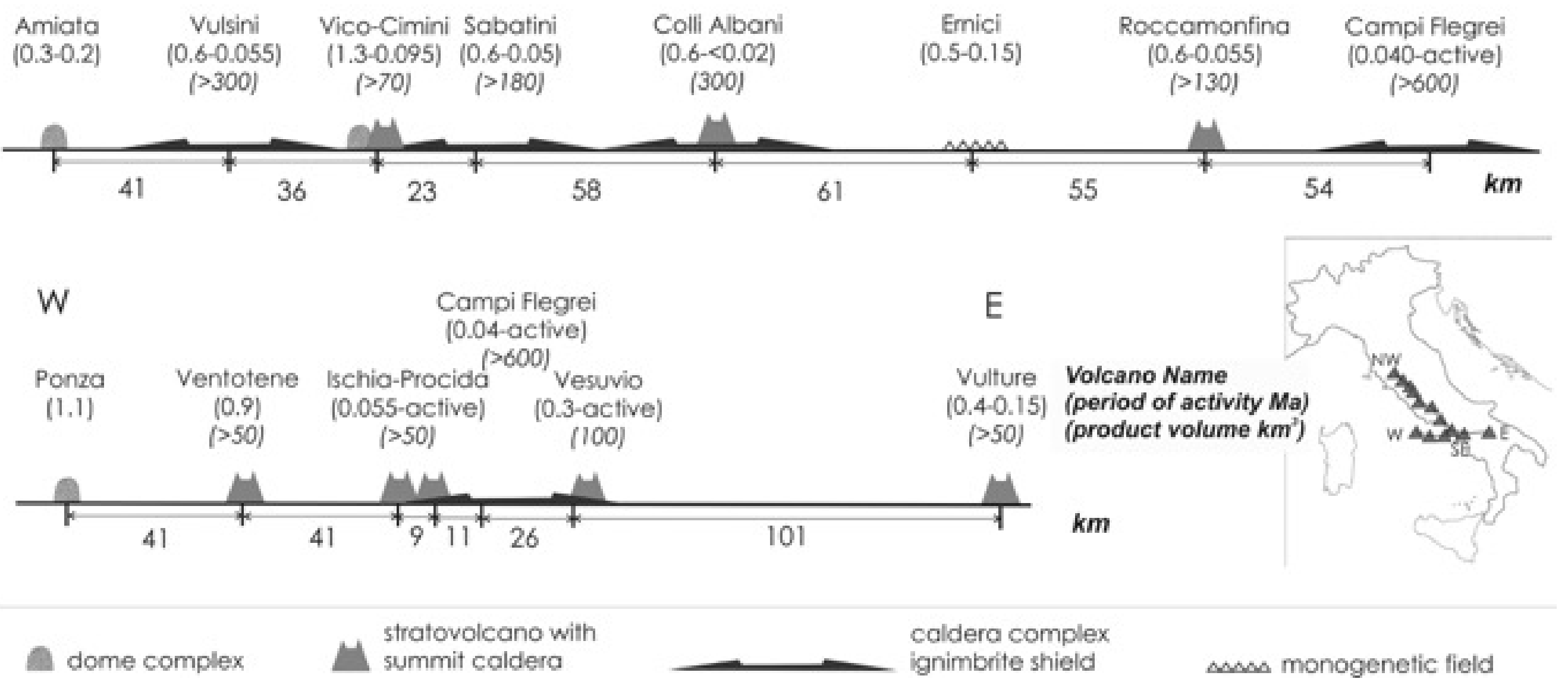

Fig. 10 - Mean spacing of alkaline potassic volcanic districts along the NW trend (Amiata-Campi Flegrei) and along the east-west trend (Ponza-Vulture Volcano). The two directions cross at Campi Flegrei volcano caldera (from Mattei et al., 2010). 


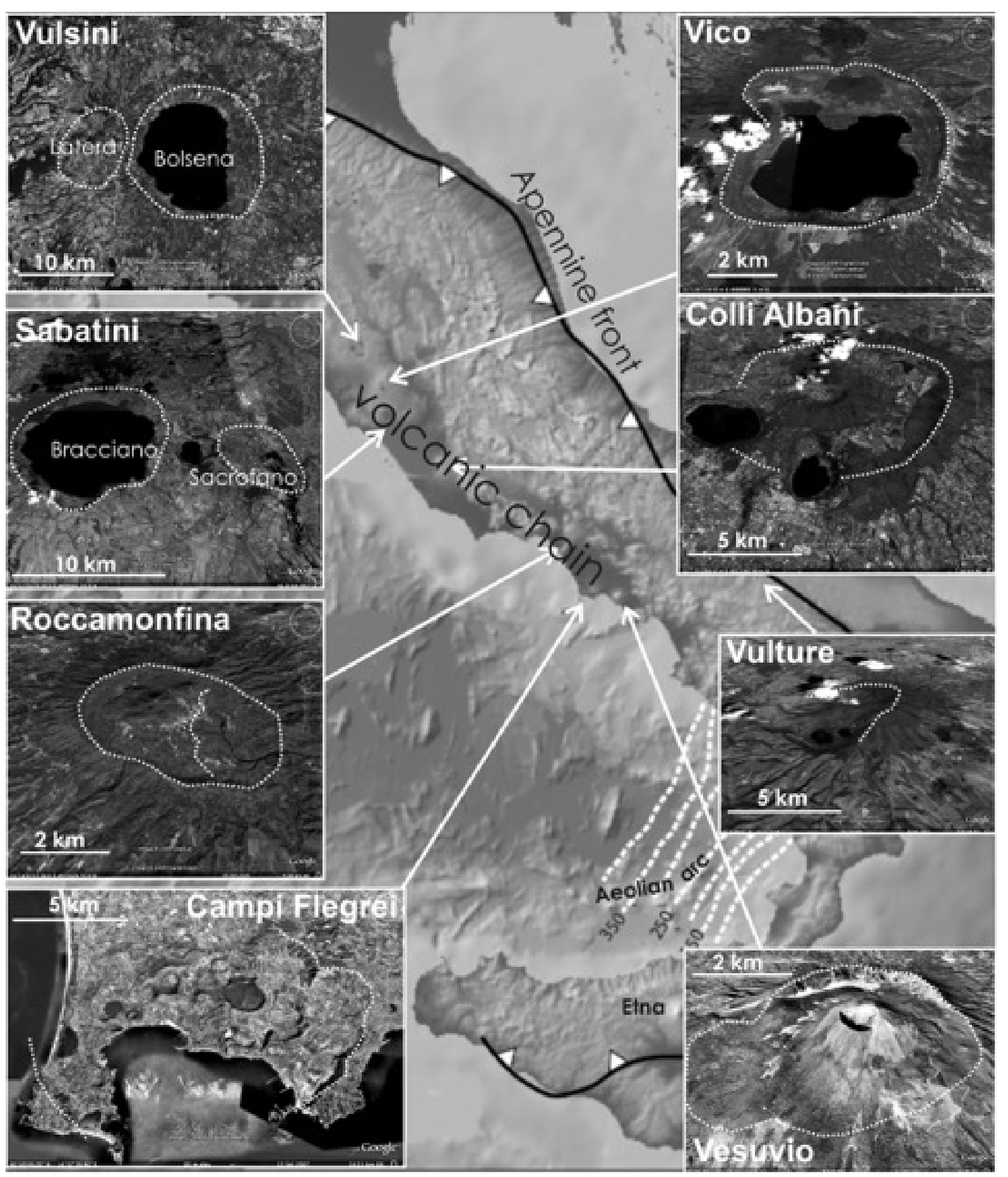

One major petrological and geochemical characteristic of the Roman volcanoes is the shift with time from leucititic to leucite-free magmatism (Avanzinelli et al., 2009; Boari et al., 2009a; Conticelli et al., 2013). This usually happens, with the exception of the Neapolitan volcanoes (Neapolitan district), after the formation of polygenic summit calderas with the present day morphology and size. Silica undersaturated leucititic magmas are volatile-rich, especially $\mathrm{CO}_{2}-$ rich, and triggered intermediate- to largevolume paroxysmal eruptions led the formation of poli-phase calderas and vast ignimbrite plateaus.

These complexes have been classified as alkaline caldera complexes (Giordano et al., 2006b; Giordano \& The CARG Team 2010) and are, from north to south in the Latian area, the Bolsena-Latera (Vulsini), the Bracciano-Sacrofano (Sabatini), the Vulcano Laziale (the early edifice of the Colli Albani volcano) and, in the Neapolitan district, the Campi Flegrei volcano (Fig. 11).

Fig. 11 - Localisation and morphology of the main on-shore volcanic districts and calderas of the Roman Magmatic Province (images from Google Earth). From Mattei et al., 2010. 
Intermittent effusive and explosive activity formed real stratovolcanoes such as, from north to south in the Latian area, Vico, Faete (the intracaldera edifice of the Colli Albani volcano), Roccamonfina, and Ventotene (mostly subaqueous), and in the Neapolitan area Ischia (mostly subaqueous), Procida (mostly subaqueous), and Somma-Vesuvius (Fig. 11). The latter volcanoes also erupted intermediate volume ignimbrites that formed small summit collapse composite calderas at Vico, Roccamonfina, Ischia, Somma-Vesuvius and Vulture. Ischia has the only resurgent caldera (Orsi et al., 1991; Acocella \& Funiciello, 1999).

One of the most relevant features of the Roman province is the twofold compositional, geochronologic and geographic characters of the Latian (e.g., Vulsini, Vico, Sabatini, Colli Albani, Middle Latin Valley, Roccamonfina districts; Fig. 1) and Neapolitan volcanoes (e.g., Ischia, Procida, Campi Flegrei and Vesuvius, Fig. 1). The former started their activity about at $600 \mathrm{ka}$ and erupted until the Holocene, with the last eruptions at ca. $40 \mathrm{ka}$ (Conticelli et al., 2010a). The latter started at about $300 \mathrm{ka}$ with historical eruptions in all volcanoes, the most recent one at Vesuvius on 1944 AD (see below).

This age division is also reflected in compositional data, because most of the volcanic rocks of the Neapolitan volcanoes, with exception of Vesuvius, are leucite-free similarly to the coeval post caldera rocks of the other Latian volcanoes (i.e., Roccamonfina, Middle Latina Valley, Colli Albani, Sabatini, Vico, Vulsini). However, one of the most striking compositional differences between Latian and Neapolitan volcanic rocks stands with the isotopic composition (Fig. 12).

\section{Origin of Italian magmatism}

The origin of the Italian potassic and ultrapotassic rocks and of their peculiar trace element and isotopic signatures has been extensively debated. The debate has focussed on two main possible genetic mechanisms: a) within-plate origin partial melting of an up-rising mantle plume (e.g., Vollmer \& Hawkesworth, 1981; Vollmer, 1989; Ayuso et al., 1998; Castorina et al., 2000; Gasperini et al., 2002; Bell et al., 2004, 2013); b) orogenic to post-orogenic partial melting of the sub-continental lithospheric metasomatised mantle at a destructive plate margin, with contributions from recycled sediments (e.g., Peccerillo, 1985, 1999, 2001, 2005a; Rogers et al., 1986; Beccaluva et al., 1991; Conticelli \& Peccerillo, 1992; Downes et al., 2002; Conticelli et al., 2004, 2007, 2015a,b; Bianchini et al., 2008).

Some of the authors suggesting a within-plate origin also point out the need for an increasing influence of an upper crustal geochemical component northward, although no convincing reasons have been provided to explain 

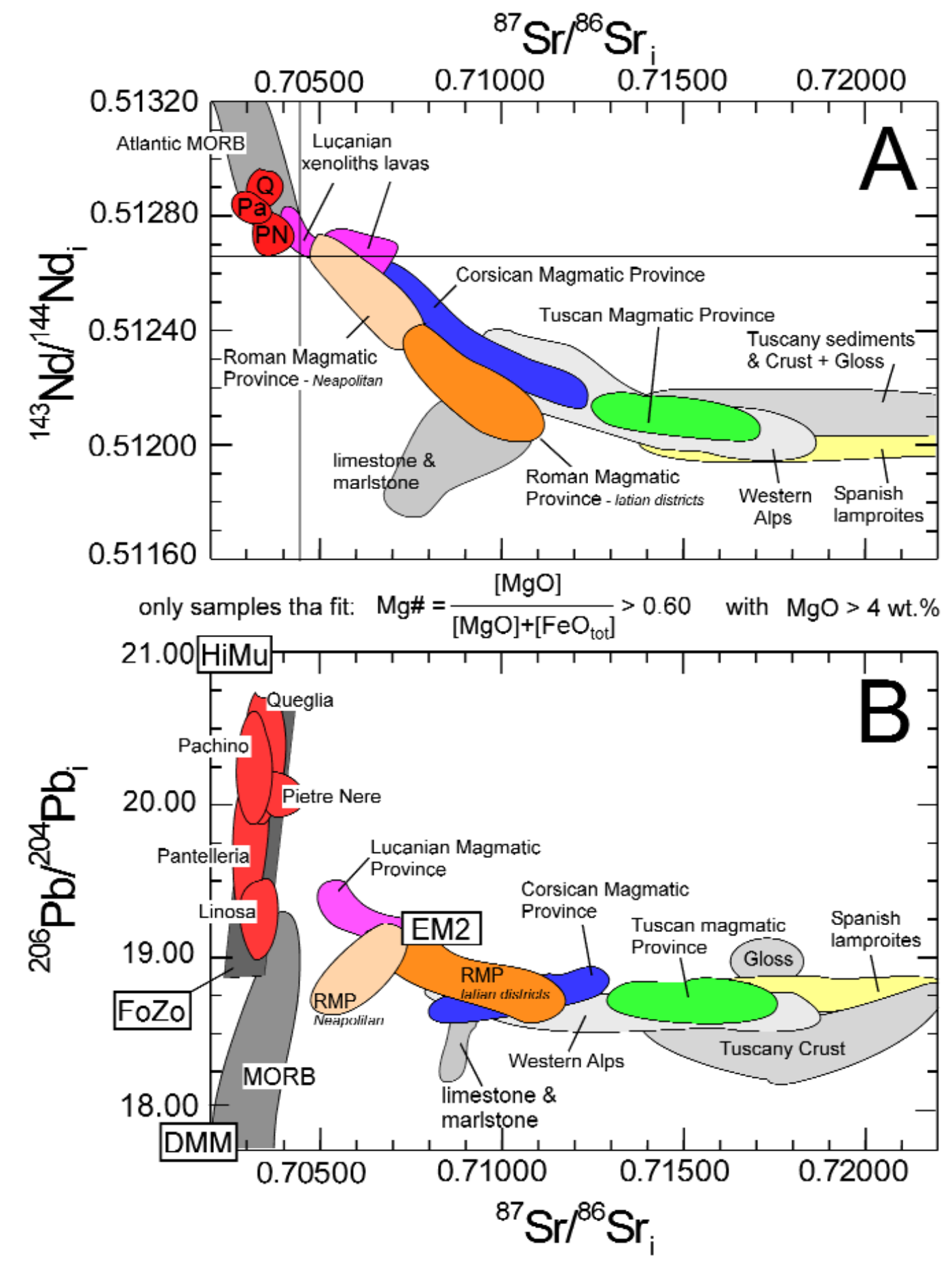

it in the frame of a within-plate, extensional geodynamic setting (e.g., Hawkesworth \& Vollmer, 1979; Vollmer, 1990; Gasperini et al., 2002; Bell et al., 2004). Indeed, in the within-plate 'plumerelated' model the crustal signature is generally attributed to shallow level magma assimilation. To explain the high radiogenic $\mathrm{Sr}$ and unradiogenic $\mathrm{Nd}$ (Fig. 12) of olivine-bearing high-Mg lamproite extremely high extent crustal assimilation is required (> 70 vol. \%). This high proportion of crustal assimilation is unlikely to occur at shallow

Fig. 12 - Plots of $143 \mathrm{Nd} / 144 \mathrm{Nd}_{\mathrm{i}}(\mathrm{A})$ and $206 \mathrm{~Pb} / 204 \mathrm{~Pb}_{\mathrm{i}}(\mathrm{B})$ vs. ${ }^{86} \mathrm{Sr} / 86 \mathrm{Sr}_{i}$ for mafic (Mg-\# > 0.60 and $\mathrm{MgO}>4$ wt. \%) Central Mediterranean ultrapotassic and associated rocks; Subscript ' $i$ ' indicates that isotopic values were age corrected, thus calculated back at the initial value of the crystallisation of magma. Mantle Zoo end members are from Stracke et al. (2005). Data are from Conticelli et al. $(1987,1991,1997,2002,2007,2009 a, 2009 b$, 2010a, 2010b, 2011, 2013, 2015a, b) Conticelli \& Peccerillo (1992), Orsi et al. (1995), Civetta et al. (1997), Ayuso et al. (1998), Conticelli (1998), D'Antonio et al. (1999a, b), Castorina et al. (2000), Mascle et al. (2001), Pappalardo et al. (1999, 2002a, b), Gasperini et al. (2002), Perini et al. (2000, 2003, 2004), Downes et al. (2002), Bell et al. (2004, 2013), Piochi et al. (2004), Cadeaux et al. (2005), De Astis et al. (2006), Peccerillo \& Martinotti (2006), Di Rienzo et al. (2007, 2011), D'Orazio et al. (2007, 2008), Owen (2007), Avanzinelli et al. (2008, 2012a, 2014), Prelević et al. (2008, 2010), Boari et al. (2009a, 2009b), Cadeaux \& Pinti (2009), Conte et al. (2016) and author's unpublished data. 
level without suffering extensive crystallization of mafic phases, and thus to led magma to complete crystallisation before achieving the required conditions. This would have decreased the $\mathrm{MgO}, \mathrm{Ni}$, and $\mathrm{Cr}$ contents of the mafic magma bringing it to the differentiated felsic side (Conticelli, 1998; Turner et al., 1999; Murphy et al., 2002). In fact, the most ultrapotassic rocks from each magmatic province (i.e. lamproites, kamafugites and lucitites), show contemporaneously the highest isotopic and geochemical crustal signature and the highest abundance in $\mathrm{MgO}$ and compatible trace elements. In addition these rocks have liquidus highly forsteritic olivine, which does not show textural features typical of extra olivine from cumulus processes. A proportion of assimilated crust higher than 40 vol. \% would rapidly freeze the magma, stalling its ascent and causing it to crystallise completely.

In summary, even a small amount of crustal contamination would result in rapid crystallization and fractionation of mafic minerals. $\mathrm{MgO}, \mathrm{FeO}, \mathrm{Ni}, \mathrm{Sc}$, and $\mathrm{Cr}$ contents would dramatic decrease in the contaminated magma with no further enrichment in $\mathrm{K}_{2} \mathrm{O}$ (Conticelli, 1998; Turner et al., 1999; Murphy et al., 2002).

In figure 13 is reported the co-variation of $176 \mathrm{Hf} / 177 \mathrm{Hf}_{i}, 187 \mathrm{Os} / 188 \mathrm{Os}_{\mathrm{i}}$, and $3 \mathrm{He} /{ }^{4} \mathrm{He}(\mathrm{R} / \mathrm{RA})$ vs. $87 \mathrm{Sr} / 86 \mathrm{Sr} r_{i}$ provides further evidence for interaction between a recycled crustal-derived component and an asthenospheric mantle end-member. A negative correlation between initial $\mathrm{Hf}$ and $\mathrm{Sr}$ isotopes is observed (Fig. 13A), with leucite-free ultrapotassic rocks (i.e., lamproites) showing the overlap with the field of sediments, similarly to other Western Mediterranean lamproites (i.e., Western Alps, Spain; Prelević et al., 2010). Leucite-bearing ultrapotassic rocks (i.e., kamafugites, leucitites) have higher $176 \mathrm{Hr} / 177 \mathrm{Hf}_{i}$ values, intermediate between those of the crustal and the mantle end-members (Fig. 13A). Young neapolitan rocks plot close to the mantle end-member suggesting the arrival in the mantle wedge of either an intraplate, through slab tear (Gasperini et al., 2002), or a massive fluid-like components (Avanzinelli et al., 2008).

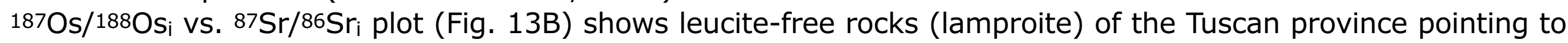
a crustal end-member, while the leucite-bearing rocks (kamafugites, leucitites) plots at lower values, but still consistently higher than typical upper mantle (e.g., Carlson, 2005). Osmium is more sensitive to shallow-crustal contamination processes than other isotopic system (e.g., Chesley et al., 2004; Chen et al., 2013). The scatter towards high 1870 s/1880s ratios observed in figure 13B can be ascribed to small amounts of shallow-level crustal contamination, although the overall isotopic trend shown cannot be such a process alone. Significant amount of recycled crustal material within the upper mantle is required for the genesis of lamproitic and kamafugitic magmas, which become diluted passing to post-leucitites of the Neapolitan district (Conticelli et al., 2007). 


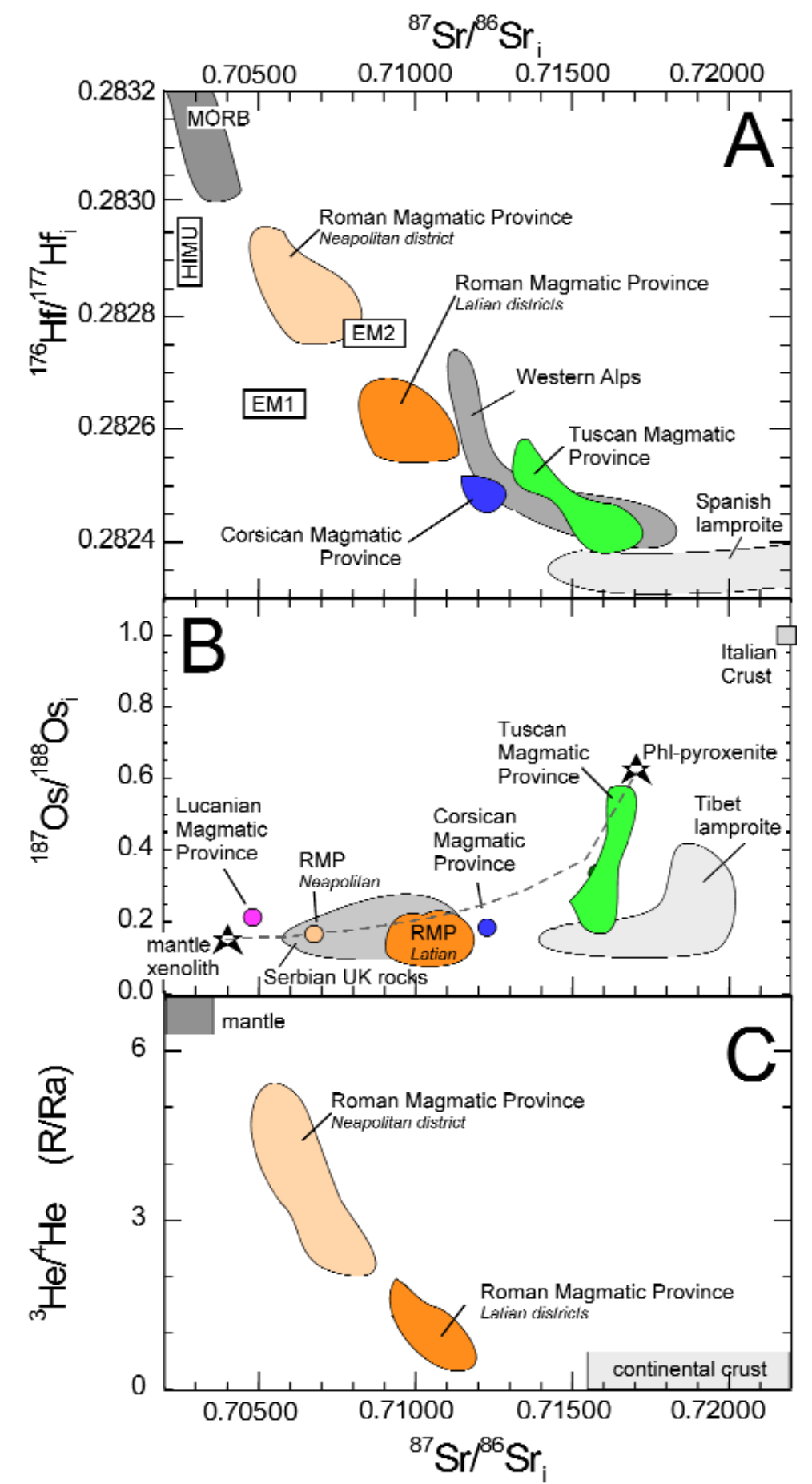

He isotopes of melt inclusions in olivine and clinopyroxene crystals from rocks of the roman rocks (leucitites and plagio-leucitites)(Fig. 13C) also indicate a recycled crustal component in the mantle source of magmas (Martelli et al., 2004).

Avanzinelli et al. (2008) reported a comprehensive study of U-Th disequilibria on the youngest Italian rocks with the aim of investigating the mechanism of source melting (Fig. 14). The authors excluded the possibility of the plume-related origin, in particular of a plume upwelling from a slab window located under the Neapolitan area, on the strength of significant $238 \mathrm{U}$-excess measured in the volcanic rocks of the Neapolitan district of the Roman Province. In fact, $238 \mathrm{U}$-excess is widely accepted as one of the key evidence of subduction-related magma genesis (e.g., Elliott et al., 1997, 2003; Hawkesworth et al., 1997). The occurrence of such excesses only in Neapolitan rocks is ascribed to the recent addition of a U-rich component requiring the occurrence of a fluid component, which is also expected to act as

Fig. 13 - Plots of $176 \mathrm{Hf} / 177 \mathrm{Hf} f_{i}(\mathrm{~A}), 187 \mathrm{Os} / 188 \mathrm{Os} \mathrm{s}_{\mathrm{i}}(\mathrm{B})$, and $3 \mathrm{He} / 4 \mathrm{He}(\mathrm{C})$ vs. ${ }_{86} \mathrm{Sr} /{ }_{86} \mathrm{Sri}$ for Central Mediterranean ultrapotassic and associated rocks; Subscript ' $i$ ' indicates that isotopic values were age corrected, thus calculated back at the initial value of the crystallisation of magma. The green curve in B represent mixing between a depleted mantle source with 3200 ppt of Os and ${ }_{187} \mathrm{Os} /{ }_{188} \mathrm{Os}=0.13$ (Walker et al., 1989) and a possible crustal component represented by an Italian crustal rocks reported in Conticelli et al. (2007) with 52 ppt Os and ${ }_{187} \mathrm{Os} /{ }_{188} \mathrm{Os}=1.004$. Data are from Gasperini et al. (2002), Conticelli et al. (2002, 2007, 2010), Martelli et al. (2004), Widom et al. (2004), Prelević et al. (2008, 2010, 2014), and Tommasini's unpublished data. Mantle Zoo end members are from Stracke et al. (2005). Redrawn after Conticelli et al. (2015a). 


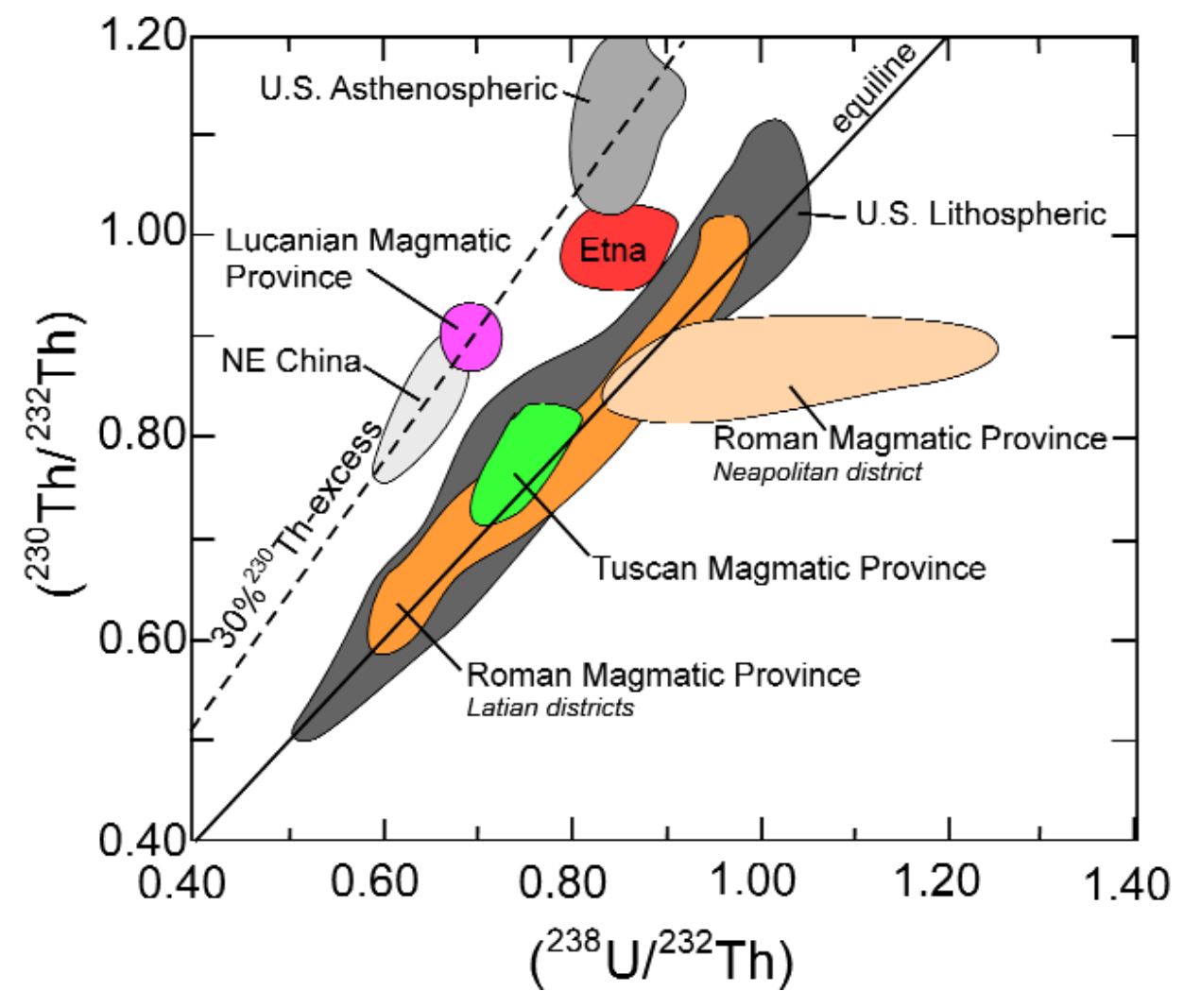

Fig. 14 - 230Th/232Th vs. (238U/232Th) equiline diagram. All activity ratios (in brackets) are age corrected (i.e. initial. Fields for within-plate continental alkalic volcanic rocks are reported for comparison and include: Etna (Condomines et al., 1995), NE China (Zou et al., 2003), US lithospheric (Asmeron \& Edwards, 1995; Reid ,1995; Reid \& Ramos, 1996; Asmeron, 1999; Asmeron et al., 2000), US asthenospheric (Asmeron \& Edwards, 1995; Asmeron, 1999; Asmeron et al., 2000). Redrawn after Avanzinelli et al. (2008).

a trigger for magmatism. The lack of any significant disequilibria in the Latian districts (Roman Magmatic Province) and Amiata rocks is also inconsistent with adiabatic melting of a deep-seated mantle plume, which would produce significant 230Th excess (Avanzinelli et al., 2008). Such excesses have only been measured in a sample from the Monticchio lakes volcanism, in the Lucanian Magmatic Province (Avanzinelli et al., 2008).

\section{Subduction-related metasomatism}

The isotopic charateristics discussed above match well with the incompatible trace element distributions ubiquitously shown by the volcanic rocks of each Italian magmatic province. It is generally thought that fractionation of High Field Strength Elements (HFSE) with respect to Large Ion Lithophile Elements (LILE) is typical of orogenic magmatic suites (e.g., Peccerillo, 1985; Hofmann, 1996, Hoefs, 2010) and that Pb peaks are generated by sediment recycling within the upper mantle (Avanzinelli et al., 2008). The relative immobility of incompatible high field strength elements and Th with respect to large ion lithophile ones in aqueous fluids has long been used to distinguish between the roles of fluids and melts during metasomatism (e.g., Hawkesworth et al., 1997; Elliott et al., 1997; Elliott, 2003; Kessel et al., 2005). Conversely, the budget of other trace elements such as Th, is controlled in arc rocks by sediment recycling (e.g., Elliott et al., 1997; Plank \& Langmuir, 1998; Plank, 2005; Tommasini et al., 2011). High Th concentrations, Th/Nb and Th/REE 
ratios in subduction-related volcanic rocks are interpreted as representative of recycled sediments. The comparison of these ratios with subducted sediments have suggested that the latter are recycled as melts (e.g., Elliott et al., 1997; Hawkesworth et al., 1997; Class et al., 2000; Elliott, 2003; Plank, 2005) enriched in Th and incompatible trace elements, but still depleted in HFSE, probably due to the occurrence of residual rutile during sediment partial melting (e.g., Elliott et al., 1997; Tommasini et al., 2007).

At sub-arc temperatures and pressures the physical distinction between fluids and melts is lost above the 'second critical end point of saturation' (e.g., Kessel et al., 2005; Hermann et al., 2006) where they converge to a 'supercritical liquid', but 'fluid'-like and 'melt'-like liquids can still be distinguished using the relative proportion of $\mathrm{H}_{2} \mathrm{O}$ and solute contents, depending upon the temperature of 'supercritical liquid' formation (e.g., Hermann et al., 2006).

Klimm et al. (2008) showed that the trace element budget of metasomatic agents released by basaltic subducting crust at at $2.5 \mathrm{GPa}$, regardless of whether they are 'fluids' or 'supercritical liquids', depends upon the solubility of accessory phases such as allanite and monazite (controlling REE and Th and $U$ ) and rutile (determining the $\mathrm{Ti}$ and $\mathrm{Nb}$ contents). At normal slab/mantle interface temperatures, these accessory phases are stabilised in the residuum during slab melting. This strongly sequesters REE, Th, (in allanite and/or monazite) and $\mathrm{Ti}$ and $\mathrm{Nb}$ (in rutile) from the metasomatic liquids.

The resulting metasomatic liquid is enriched only in the elements not hosted in the residual accessory phases ( $\mathrm{Cs}, \mathrm{Rb}, \mathrm{Ba}, \mathrm{K}, \mathrm{Pb}, \mathrm{Sr}$ and $\mathrm{U}$ over $\mathrm{Th}$ ), perfectly reflecting the widely accepted composition of the slab derived aqueous 'fluids'. With increasing temperature or/and pressure the metasomatic liquids incorporate higher amounts of solutes (i.e. 'melts'), and the solubility of allanite, monazite and rutile increases until they are eventually eliminated from the residue with Th, and REE released into the melts (Hermann, 2002; Kessel et al., 2005; Klimm et al., 2008). However, until over-saturated, allanite and rutile will completely control the REE, Th, $U$ (allanite) and $\mathrm{Ti}, \mathrm{Nb}$ (rutile) content of the sedimentary 'melts'. Similar conclusions have been reached by Skora \& Blundy (2010) starting from radiolarian clay-rich sediments.

Allanite and monazite have partition coefficients for LREE and Th much higher than those of heavy REE (HREE) and $U$; thus allanite-saturated 'melts' from recycled pelitic sediments would have lower LREE/HREE and higher $\mathrm{U} / \mathrm{Th}$ than their sedimentary protolith. If temperatures are high enough to keep the metasomatic liquids undersaturated in such minerals, then the Th, $U$ and REE can be released into the liquids and their trace elements contents and ratios will depend on other mineral phases. 
Cs Po BaTh U K TaNbLaCePbNd Sr P SmH Zr EU TI To Y YbLu

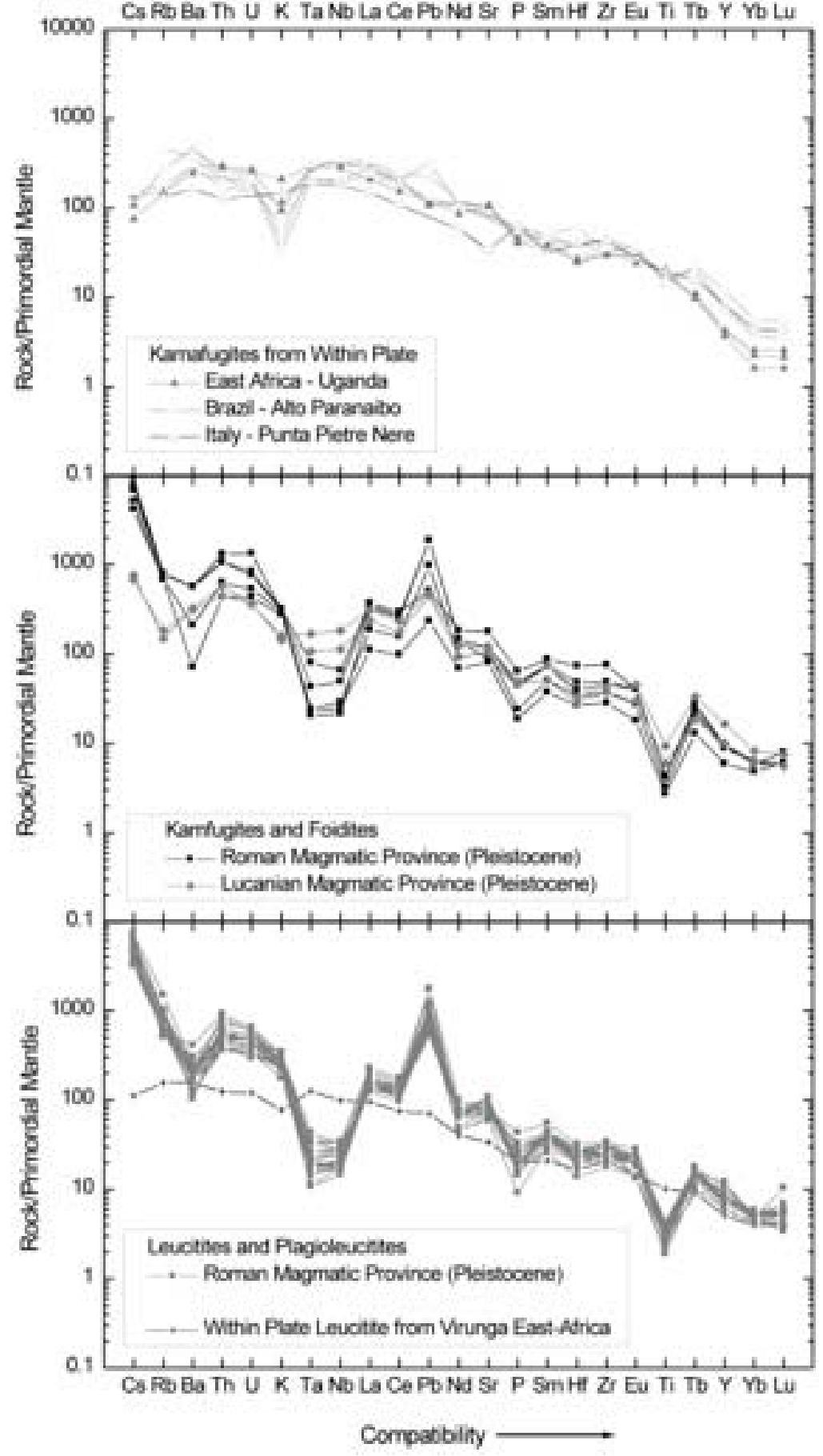

The high Th/U and LREE/HREE of most Italian rocks (with the notable exception of the Neapolitan district) suggest that the dominant metasomatic agent was a 'melt' generated at temperatures where rutile was stable. In this frame the high LREE/HREE of most Italian ultrapotassic and associated shoshonitic rocks has been ascribed to the role of garnet during sediment partial melting to produce the metasomatic 'melt' (Avanzinelli et al., 2009). This is consistent with the amount of residual garnet observed during experiments of melting in both basaltic crust (Kessel et al., 2005) and carbonate pelitic (Kerrick \& Connolly, 2005) sediments. The possibility of acquiring a garnet signature during by deep melting in the garnet stability field (i.e. metasomatised mantle source deep enough to stabilise garnet) was ruled out by Avanzinelli et al. (2009) on the basis of the lack 230Th excess (see also Asmerom, 1999).

The dominant role of sediment derived 'melts' does not exclude the involvement of 'fluids' generated at lower temperature, but

Fig. 15 - Patterns of incompatible trace elements normalised to the primordial mantle (Sun \& McDonough, 1989) for mafic ultrapotassic rocks $(\mathrm{Mg} \#>65 ; \mathrm{Ni}+\mathrm{Cr}>400 \mathrm{ppm})$ of the Roman Magmatic Province compared with the pattern of a leucite-bearing basanite from Virunga (Rwanda), kamafugites from Toro Ankole (Uganda), and ultrapotassic rocks from Alto Paranaiba (Brazil). Element order in the abscissa follows the increasing compatibility of the element according to Hofmann (1997). Data are from: this work; Conticelli et al. (1991, 1997, 2002); Conticelli \& Peccerillo (1992); Carlson et al. (1996), Tappe et al. (2003), and Perini et al. (2004). Note that within-plate ultrapotassic rocks (i.e., leucitite from Virunga; kamafugites from Brazil and Toro Ankole) have no negative spikes at $\mathrm{Ta}, \mathrm{Nb}$, and $\mathrm{Ti}$, and no positive spikes at $\mathrm{Th}, \mathrm{U}$, and $\mathrm{Pb}$, whereas within-plate kamafugites have a negative spike at $K$, which is not observed in Italian rocks (from Conticelli et al., 2007). 
simply diminishes their effect on the final composition of the metasomatised mantle source, given their smaller ability of carrying trace elements with respect to 'melts' (Hermann et al., 2006). In fact a widespread fluidlike component might have permeated the mantle source of Italian magmas in a more pervasive way than the melt-like metasomatism that generates the most enriched ultrapotassic products.

The role of metasomatic 'fluids' vs. 'melts' is evident in a Ba/Th vs Th/Nb plot (Fig. 16). A negative correlation is ubiquitous, but the various magmatic provinces define different trends. The widest range is shown by the volcanic rock of the Roman Magmatic Province, where a decrease in Th/Nb, coupled with increasing Ba/Th, is evident passing from the oldest and northernmost districts (i.e. Latian districts) to the youngest and southernmost one, which is the Neapolitan district. Leucite-free (i.e., shoshonite) volcanic rocks from the postcaldera and the most recent periods of the Roccamonfina and Middle Latin Valley volcanoes, the two Southernmost of the Latian districts of the Roman Province (above the 41st parallel; Fig. 1), show Th/Nb vs.

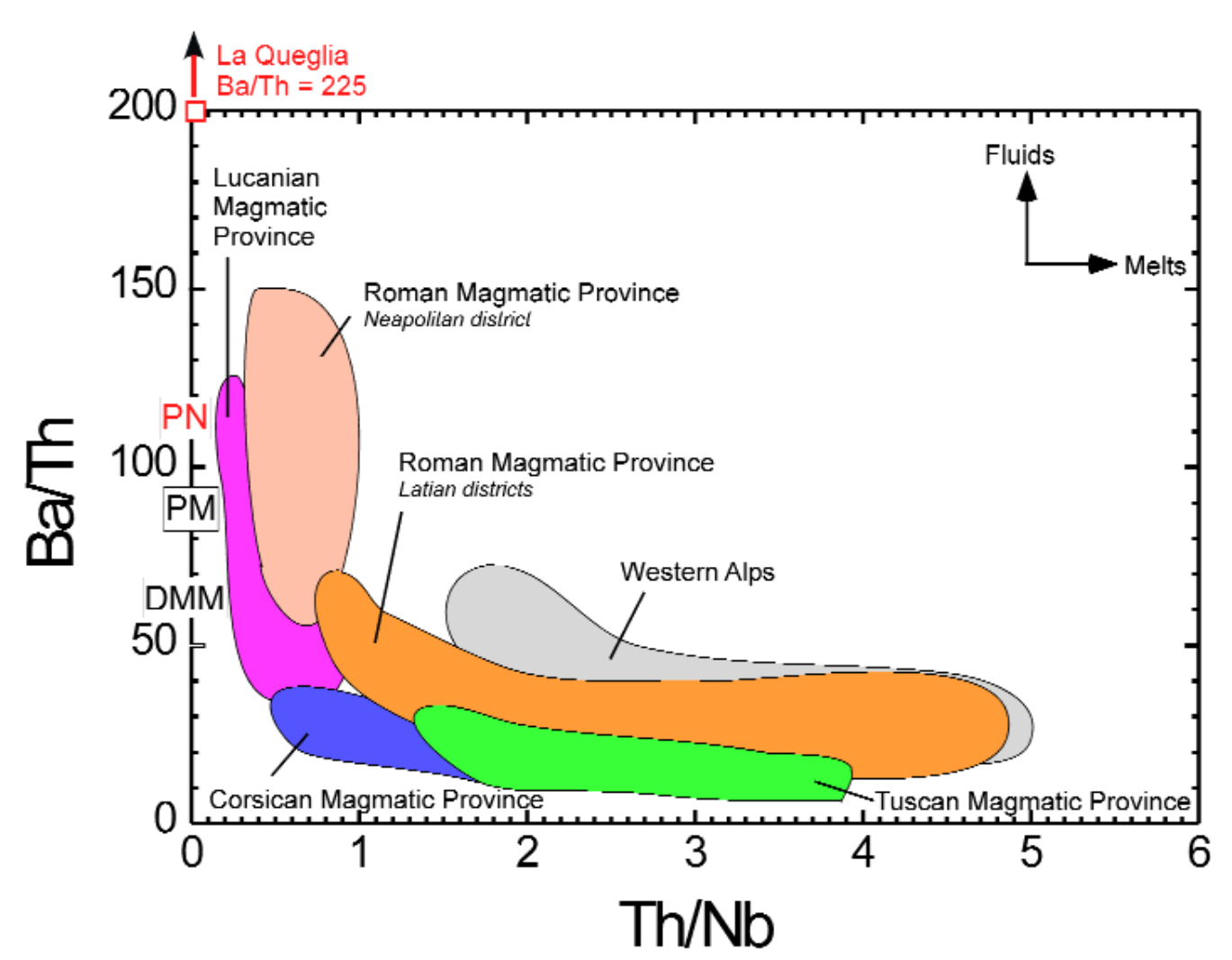
$\mathrm{Ba} / \mathrm{Th}$ values that fill the gap. The occurrence of significant $238 \mathrm{U}$-excess in volcanic rocks from the Neapolitan district (Avanzinelli et al., 2008) confirms a major role for a young (few ka, see Avanzinelli et al., 2008) fluid-like metasomatic component (i.e.

Fig. 16 - Ba/Th vs. Th/Nb for the Italian ultrapotassic rocks. Plotted rocks with $\mathrm{MgO}>4.5$ wt. \%. Data from Conticelli et al. (1987, 1991, 1992, 1997, 2002, 2004, 2007, 2009a,b, 2010a,b, 2011, 2013, 2015a, 2015b), D'Antonio et al. (1996, 1999a,b), Ayuso et al. (1998), Conticelli (1998), Pappalardo et al. (1999, 2002a,b), Perini et al. (2000, 2003, 2004), Beccaluva et al. (2002), Downes et al. (2002), Cadeaux et al. (2005), De Astis et al. (2006), Peccerillo \& Martinotti (2006), Di Rienzo et al. (2007), D'Orazio et al. (2007, 2008), Owen (2007), Prelević et al. (2008, 2010), Stoppa et al. (2008), Avanzinelli et al. (2008), Boari et al. (2009a, b), Cadeaux \& Pinti (2009), Melluso's unpublished data; Conticelli's unpublished data. Redrawn after Avanzinelli et al. (2009), and Conticelli et al. (2010a). 
allanite/monazite saturated); the position of the youngest products of Roccamonfina and Middle Latin Valley in figure 16, along with their vicinity in space and time to the Neapolitan district might indicate a role for such a fluid component also in these magmas.

An increase of $\mathrm{Ba} / \mathrm{Th}$ is also observed passing from ultrapotassic rocks (lamproites and minettes) to associated shoshonites and high-k calc-alkaline rocks within the products of the Tuscan Magmatic Province and Western Alps). As discussed above, this might suggest the presence of pervasive fluid-related metasomatism which is overshadowed by the recycled sediment melt component which dominates the geochemical composition of the most enriched magmas (see next section). The opposite occurs in the Western Tyrrhenian (i.e. Corsica Province). Ultrapotassic magmas from Sisco (Corsica) display low Th/Nb and Ba/Th values (Fig. 16), with the latter even lower than upper mantle values $(P M=82.2$, DMM $=48-60 ;$ Wood, 1979; Sun \& McDonough, 1989), with little HFSE/LILE fractionation. These characteristics suggest that the orogenic component in Corsica was significantly different than that responsible for the other provinces, less important or possibly even absent (Avanzinelli, 2009; Conticelli et al., 2009a).

In summary Italian ultrapotassic rocks, both leucite-free and -bearing, with the exclusion of the Sisco lamproite (Corsica), were generated in a lithospheric upper mantle enriched in $\mathrm{K}$ and incompatible elements by pelitic sediments recycled mostly as 'melts' (e.g., Conticelli et al., 2007, 2009a; Avanzinelli et al., 2008, 2009).

Further issues to be addressed are: i) the time-related and geographic transition from Tuscan lamproite-like ultrapotassic magmas (silica-saturated, leucite-free) to Roman kamafugitic/leucititic-type ones (silicaunderstaurated, leucite-bearing); ii) the temporal and geochemical sequence from ultrapotassic products to shoshonites and high-K calc-alkaline rocks within each magmatic province.

\section{Geodynamic scenario}

Ultrapotassic and associated shoshonitic to high-K calc-alkaline volcanic rocks of the Italian region have been produced from anomalously enriched upper mantle source following sediment recycling at a destructive plate boundary. Sediment-derived 'melts' represent the dominant metasomatic agent responsible for the establishment of a metasomatic vein network, but a more pervasive 'fluid'-like metasomatism is also present. The extreme enrichment in Th and the fractionated REE pattern of the erupted rocks suggests the presence of garnet in the residuum during the partial melting of the recycled sediments brought into the mantle through 
subduction and crustal delamination. This implies that temperatures during sediment partial melting were high enough to exhaust other accessory phases, such as allanite and/or monazite. These temperatures are higher than those generally expected at the slab/mantle interface, indicating that sediment melting occurred in the hot, central regions of the mantle wedge rather than at the slab/mantle interface. Large negative HFSE anomalies and fractionated REE patterns require both rutile and garnet in the residuum.

The first episode of magmatism occurred during the Oligocene within the Western Alps, and it was related to the Alpine collision. Lamproite-like ultrapotassic magmas were generated in association with shoshonitic, high$\mathrm{K}$ calc-alkalic and calc-alkalic magmas. Magmas were emplaced during the post-collisional stages of the Alpine chain. Peccerillo \& Martinotti (2006) provide evidence that the same metasomatic Alpine event also occurred in Corsica and Tuscany earlier Apennine orogenic activity started.

Reactivation of this old metasomatised should has promoted the partial melting and the formation of Corsica and Tuscan lamproites (Poli \& Peccerillo, 2016). The Sisco lamproite (Corsica) has a within plate signature that dominate over the orogenic ones, whereas the Tuscan lamproitic rocks have a slightly different isotopic signature with respect to the Western Alps (Conticelli et al., 2009a).

During the Tortonian, shoshonitic and high-K calc-alkaline rocks were emplaced along the western margin of the Tyrrhenian Sea (Fig. 17) possibly related to a westward dipping Apennine subduction zone (e.g., Doglioni, 1994; Faccenna et al., 1997, 2001, 2004; Jolivet et al., 1998; Doglioni et al., 1999; Rosembaum et al., 2002, 2008). Backward migration of the subducted slab and consequent isotherm relaxation triggered the generation of lamproitic magmatism in the Italian peninsula after the beginning of continental collision. Shoshonites and high-K calc-alkaline rocks followed the eruption of lamproites (Fig. 17) as a consequence of the increasing heat flow that melt of a larger portion of the mantle wedge, to the surrounding mantle becoming dominant with respect to metasomatised veins. Magmatism progressively moved eastward.

The metasomatic event was possibly not generated during the Apennine subduction but through several events of subduction of the Tethys Ocean beneath the European plate (i.e., Tommasini et al., 2011). During the upper Pliocene to lower Pleistocene the lamprotitic to shoshonitic magmatism furtherly migrated eastward with an arcuate distribution immediately behind the Apennine chain where post-orogenic extension started to produce NW-SE elongate basins (Fig. 17).

After a hiatus of several hundred thousand years, during the Middle Pleistocene (Fig. 17), magmatism shifted its composition from silica saturated and leucite-free to silica-undersaturated, with formation of kamafugitic to 

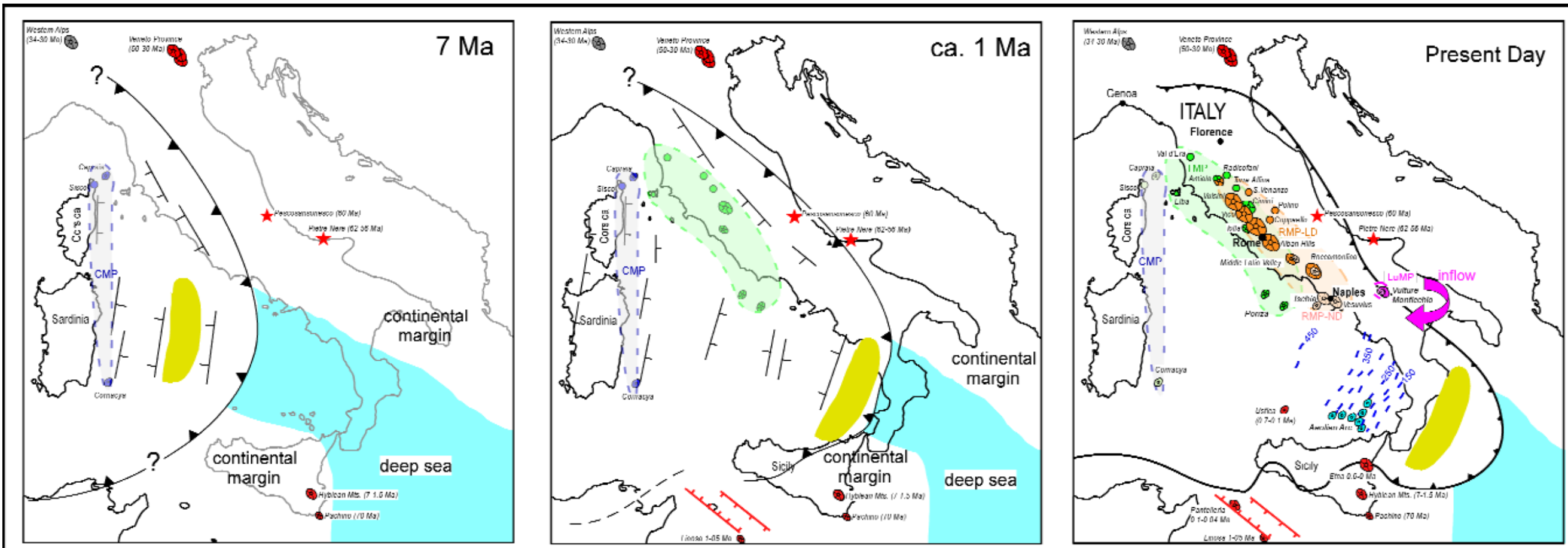

CMP Corsican Magmatic Province

I MP Tuscan Magmatic Province

RMP Roman Magmatic Province

LuMP Lucanian Magmatic Province
(9.) Volcanic districts (composite volcanoes)

Monogenetic volcano, dykes, hypabyssal body

(2) Aeolian Arc-calc-alkalic volcanoes
$250 \ldots$ _ Position and depth of present-day benioff zone

Cenozoic to present time Withinplate rocks
$\star$ external to Apennine-Tyrrhenian system
Forearc basin

Normal Faults

inflow from slab window

Fig. 17 - Schematic tectonic evolution of Central Mediterranean region from late Miocene to present time. Redrawn after Faccenna et al. (2004), Cifelli et al. (2007), Avanzinelli et al. (2009), Conticelli et al. (2010a).

plagioclase leucititic and leucititic magmas, which were erupted along the same plumbing system used by the late Tuscan magmas. In some cases hybridism between Roman and Tuscan magmas took place during the early phases of the Roman volcanism (e.g., Palaeo-Bolsena, Rio Ferriera formation at Vico, Morlupo volcanic rocks at Sabatian district), in other cases Roman magmatism reactivated old Tuscan magmatic reservoirs bringing hybrid rocks to form the Amiata volcano (e.g., Conticelli et al., 2015b; Marroni et al., 2016). 
The newly arrived magma was silica-undersaturated and was generated in response to the recycling of carbonate-rich pelitic sediments within the mantle wedge during last collisional phases. This carbonate-rich metasomatism produced phlogopite-bearing wehrlitic veins, which trigger partial melting under high $X_{\mathrm{co}}$, to give rise to kamafugites and leucitites (Conticelli et al., 2002, 2015a; Ammannati et al., 2016). A further eastward migration of magmatism occurred at the passage from Middle to Upper Pleistocene with the formation of kamafugitic magmatism in intra-apennine area (Fig. 17, Present day).

During the late Pleistocene asthenospheric mantle from the foreland started to inflow into the mantle wedge through a slab-tear located close to the Bradanic trough. Trace element ratios and isotopic values are consistent with the involvement of a within-plate mantle component similar to that of the asthenospheric mantle of the Adria microplate foreland.

The Lucanian Magmatic Province with the nested Vulture and Monticchio volcanoes is located at the extreme edge of the overriding plate, where the mantle wedge would have been reduced or absent. Toroidal inflow of hot asthenospheric material into the mantle wedge produced partial melting of the convecting mantle, which interacted with the small amount of metasomatised mantle wedge peridotite as recorded by Downes et al. (2002). This resulted in magmatic rocks with intermediate geochemical characteristics between orogenic and within-plate. Inflow is favoured by the south-eastward roll back and progressive fragmentation (i.e., detachment: Wortel \& Spakman, 2000) of the subducting plate which is now reduced and segmented into narrow tongues of the original slab (e.g., Wortel \& Spakman, 2000; Faccenna et al., 2004; Mattei et al., 2007; Rosembaum et al., 2008). The asthenosperic mantle flow through the tear within the subducted slab with time moved into the southern Italian mantle wedge. The motion of the asthenospheric mantle from the foreland into the mantle wedge is recorded by the less evident within-plate signature observed in the rocks of the Neapolitan volcanoes (e.g., Peccerillo, 2001; De Astis et al., 2006), and to a lesser extent by the sub-alkaline recent volcanic rocks of the Roccamonfina (Boari et al., 2009b; Conticelli et al., 2009b).

The location of the main tears are controlled by the presence of lateral heterogeneities in the subducting slab such as those represented by the transition from the Ionian oceanic lithosphere to the Apulia and Hyblean continental lithosphere. Such heterogeneities are also responsible for the bend of the Calabrian Arc. In the Vulture volcanic area, the presence of a lateral tear in the subducting slab is suggested by the differing behaviours of the foreland areas southeast and northwest of the volcano, corresponding to the transition from the thick carbonate Mesozoic succession of the Apulian platform to the transitional and basinal facies 
outcropping in the Gargano area. The beginning of magmatism at Vulture Volcano marks the vertical rupture of the subducted plate. In the Lucanian Magmatic Province this scenario is also supported by a 230Th-excess measured in a sample from the Monticchio Lake maars, suggesting an important role for adiabatic melting in an up-welling asthenospheric mantle source (Avanzinelli et al., 2008, 2012).

On the basis of the time of occurrence of the within-plate component we suggest that the slab-tear below the Vulture Volcano formed before the middle Pleistocene, indeed the early Vulture volcanic products, which are as old as $0.7 \mathrm{Ma}$, show the presence of the within-plate component. However, the northward slab-tear opening occurred significantly later. Indeed the ultrapotassic magmatism during the Middle Pleistocene at Roccamonfina was not affected by this component. The within plate component appears in this volcano at about $0.35 \mathrm{Ma}$. Since then the within-plate component has invaded the Neapolitan mantle wedge.

Eventually, during the Holocene a further metasomatic agent arrived in the Neapolitan region and produced the U-Th isotopic characteristics of the Vesuvius, Ischia and Campi Flegrei magmas (Avanzinelli et al., 2008). The U-Th disequilibria require the addition, shortly before the eruption of the magmas of the Neapolitan district $(<10 \mathrm{ka})$, of a U-rich component, which has affected neither the Latian district of the Roman Magmatic Province nor the Monticchio lakes volcanic products of the Lucanian Magmatic Province (Avanzinelli et al., 2008). 


\section{Day 1: Somma-Vesuvius Volcano}

\section{Roman Province: The Neapolitan District}

The Neapolitan district is the southernmost cluster of volcanoes of the Roman Magmatic Province, just south of the 41st parallel, and comprises four main volcanic edifices: Ischia, Procida, Campi Flegrei and Somma-Vesuvius volcanoes (Fig. 18). Most of the Neapolitan district volcanoes developed during the Upper Pleistocene with intense volcanic activity over the Pleistocene-Holocene boundary

The Neapolitan District

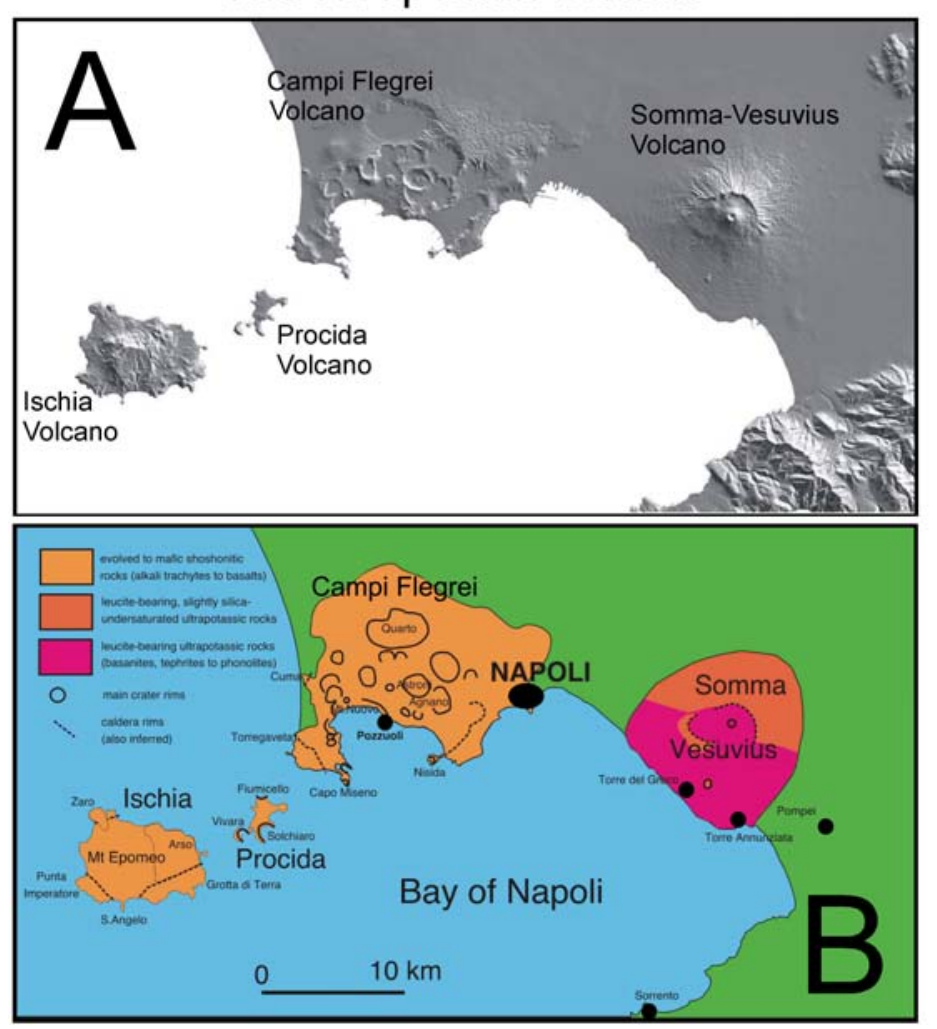

Fig. 18 - Digital Elevation Model (A) and geological sketch map of the Neapolitan district (Roman Magmatic Province; B).
(Brocchini et al., 2001; De Vivo et al., 2001; Deino et al., 2004), as well as several important historical eruptions (e.g., Ischia, Campi Flegrei, Vesuvius; e.g., Santacroce, 1987; Rosi \& Sbrana, 1987). A wealth of data regarding the recent phases of activity of these volcanoes is available, but we know less about the Middle Pleistocene history of the Neapolitan volcanoes, because most of it is buried by Holocenic volcanic activity, or are below the sea level. Shoshonitic volcanic products dominate over leucite-bearing ultrapotassic rocks. In addition, in most of the Neapolitan volcanoes the silica-undersaturated ultrapotassic rocks are completely missing in the geological record, with the exception of Somma-Vesuvius, where they appear after a long period characterised by either leucite-free or -poor volcanic rocks (Conticelli et al., 2004, 2010a; Peccerillo, 2005a).

On the basis of subsurface data from drill cores in the Campanian Plain, Cinque et al. (1993) indicate that the southern part of the plain was above sea level during the Middle Pleistocene when the older potassic and ultrapotassic rocks of the district were erupted (330 ka; Brocchini et al., 2001). The volcanic rocks cover an area as large as the entire Campanian Plain, and some tephra horizons that originated from the largest eruptions of the Campi Flegrei and Ischia volcanoes can be found throughout the Mediterranean basin and over. The 
geological evolution of the Campanian Plain, and its relationships with Neapolitan volcanic activity were studied in detail (Brancaccio et al., 1991; Cinque et al., 1993). The volcanic complexes are made up mainly of pyroclastic rocks with subordinate lava flows.

\section{Somma-Vesuvius Volcano}

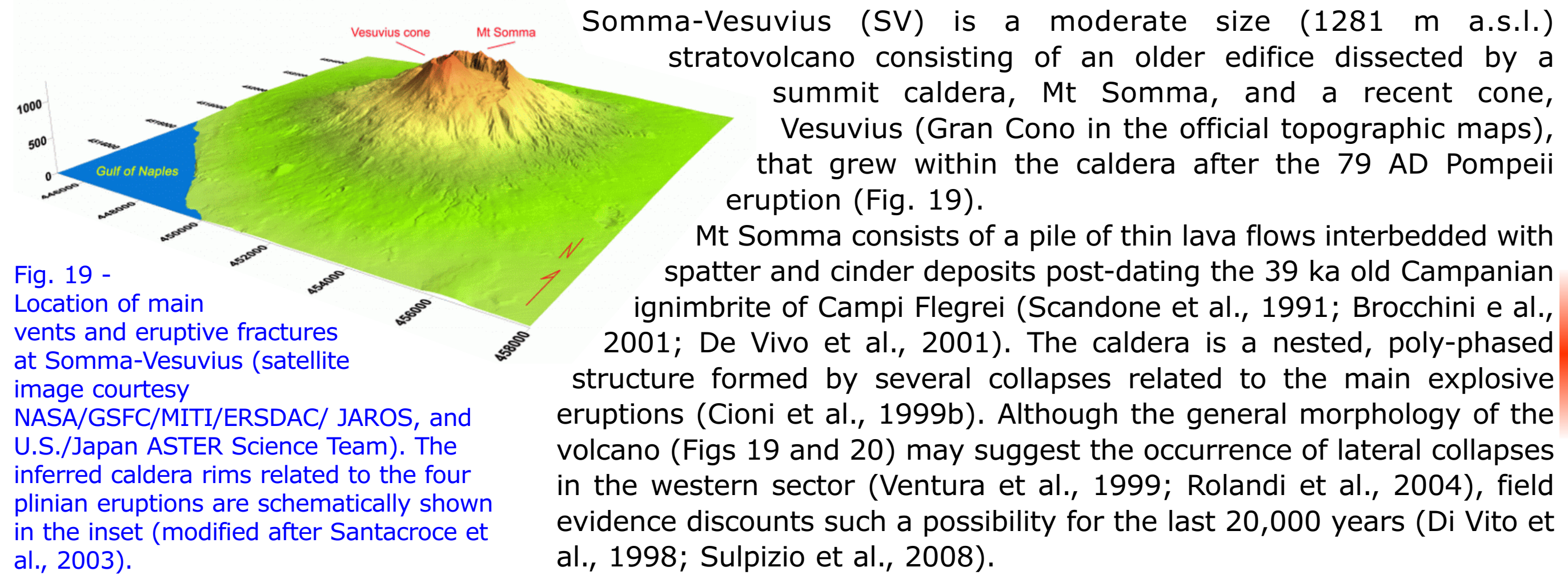

About 22 ka ago, the mainly effusive activity of Mt Somma abruptly changed into largely explosive activity (Fig. 21). At least four high-magnitude plinian eruptions occurred, staggered with minor events. The first plinian event, the "Pomici di Base" eruption, ejected trachytic to latitic magmas (Bertagnini et al., 1998; Landi et al., 1999) and was followed, after about $3 \mathrm{ka}$, by the Greenish pumice sub-plinian eruption, characterised by a very similar magma composition (Cioni et al., 2003). A few latitic lava flows and cinder cones from lateral vents are interlayered with the products of these eruptions (Santacroce, 1987; Di Renzo et al., 2007). In the following 16 ka three other plinian events occurred, each preceded by variably long repose periods: Mercato pumice eruption 

(8.9 ka, phonolite; Rolandi et al., 1993a; Cionitet
1999b; Mele et al., 2011), Avellino pumice eruption (3.9 ka, phonolite - tephriphonolite; Lirer et al., 1973; Rolandi et al., 1993b; Cioni et al., 2000; Sulpizio et al., 2011a, b), and Pompeii pumice eruption (79 AD, phonolite tephriphonolite; Lirer et al., 1973; Sigurdsson et al., 1985; Cioni et al., 1995).

Scattered pumice-bearing deposits of minor explosive events crop out in between the Greenish pumice and the Mercato pumice deposits, and between the latter and the following Avellino pumice (Santacroce \& Sbrana, 2003). Activity became more frequent after the Avellino pumice, with at least 8 explosive eruptions and some lava flows which preceded the 79 AD Pompeii pumice eruption (Andronico \& Cioni, 2000; Di Renzo et al., 2007).

The Vesuvius cone began to form after $79 A D$, growing discontinuously during periods of open conduit activity, which possibly occurred in the I-III centuries, V-VIII
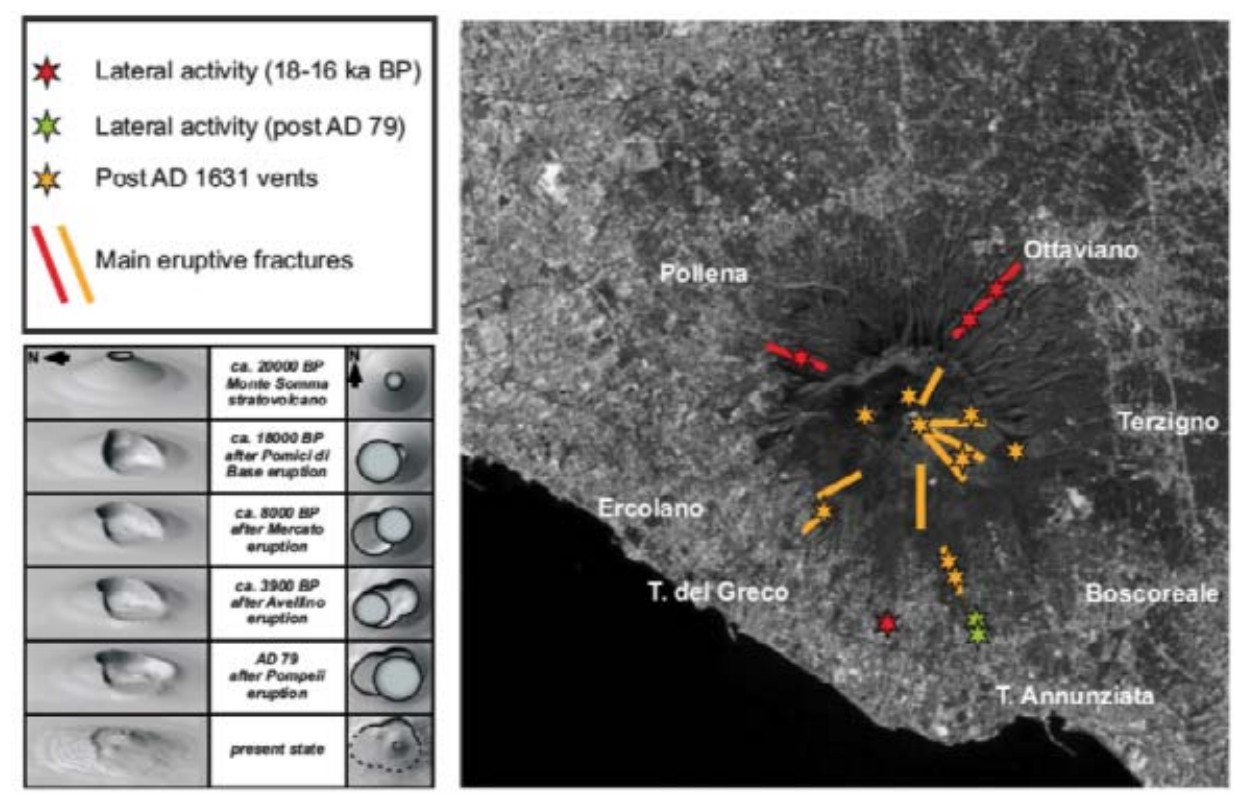

Fig. 20 - Location of main vents and eruptive fractures at Somma-Vesuvius (satellite image courtesy NASA/GSFC/MITI/ERSDAC/ JAROS, and U.S./Japan ASTER Science Team). The inferred caldera rims related to the four plinian eruptions are schematically shown in the inset (modified after Santacroce et al., 2003). centuries, X-XII centuries and in 1631-1944. Highintensity, explosive eruptions sporadically occurred, the two largest being the subplinian events of 472 AD (also known as Pollena eruption) and 1631 AD. The most recent period (1631-1944) was characterised by summit or lateral lava effusions and semi-persistent, mild explosive activity (small lava fountains, gases and vapour emission from the crater) interrupted by pauses lasting from months to a maximum of seven years. The activity of this period has been subdivided in 18 "cycles", each closed by a more intense, explosive-effusive, polyphase eruption ("Final Eruption"; Carta et al., 1981; Santacroce, 1987; Arrighi et al., 2001).

The eruptive vents of the largest eruptions possibly occupied slightly eccentric positions with respect to the Somma cone as evidenced by the shape of the caldera and the dispersal of the products (Fig.19). Vent position migrated irregularly with time inside the present caldera. Lateral activity was minor and, starting from the 79 AD, the few 


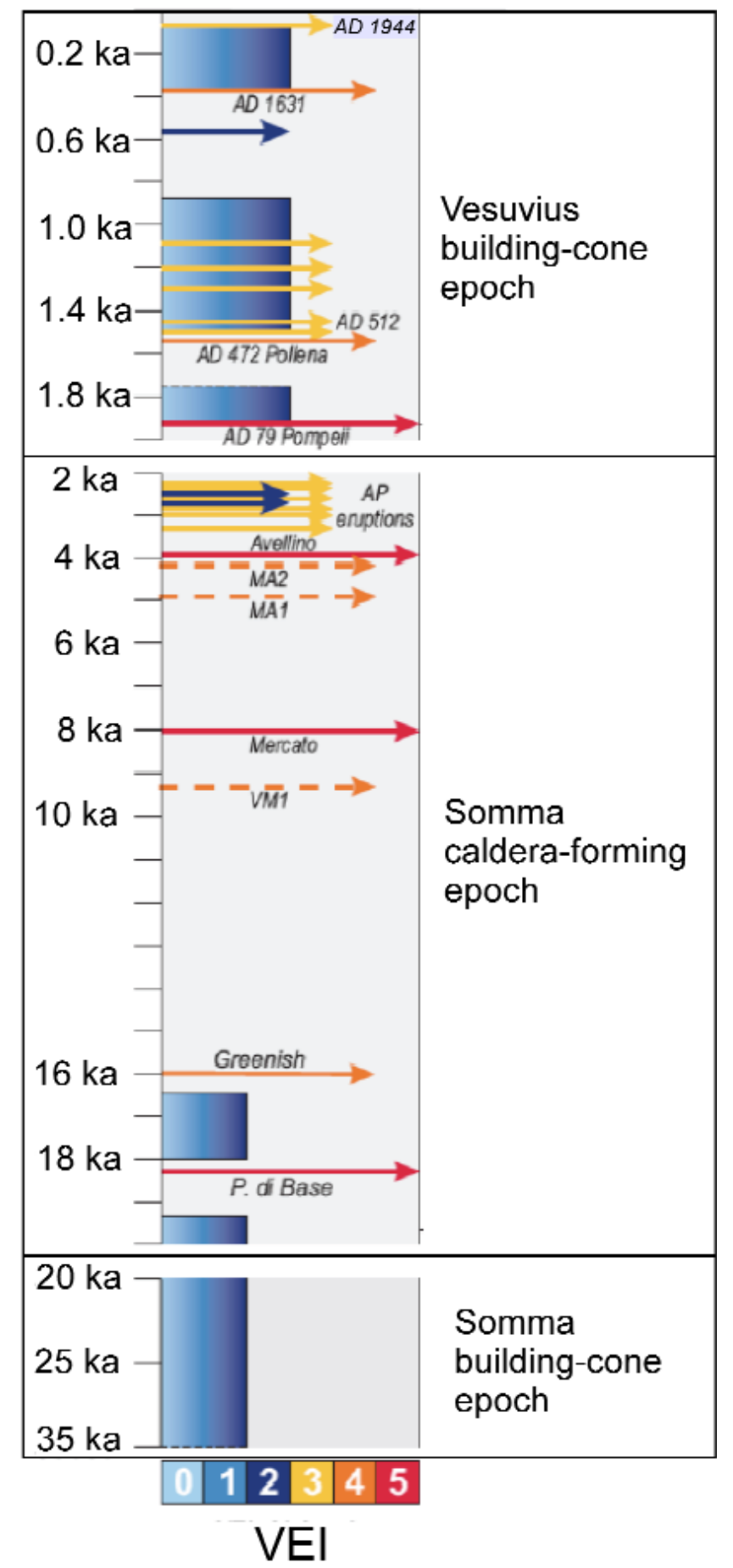

Fig. 21 - Chronogram of the Somma-Vesuvius activity. Arrows indicate explosive eruptions with length and colour according to the estimated VEI (Volcanic Explosivity Index). Blue strips show recorded or inferred periods of persistent mild strombolian and effusive activity, punctuated by VEI 2-3 explosive eruptions. Orange-dashed arrows mark eruptions of uncertain source. Breaks in the chronogram mark changes of time-scale (modified after Cioni et al., 2008).

eruptive fissures that did form were confined to the western and southern sectors of the volcano. (Cortini \& Scandone, 1981; Santacroce, 1987; Acocella et al., 2006).

\section{Magma composition}

The Somma-Vesuvius products display, with very few exceptions, a potassic to ultrapotassic character in the sense of Carmichael (1967), exhibiting a wide variability from nearly silica-saturated (normative nepheline $<5 \%$ ) to silica-undersaturated (leucite-normative), although no strongly silica-undersaturated rocks are found in the Neapolitan district (larnite-normative). According to these features Joron et al. (1987) and Ayuso et al. (1998) used the age and the degree of silicasaturation to distinguish three different groups of rocks: 1) slightly silicaundersaturated, older than the Mercato eruption (35 to $18 \mathrm{ka}$, pale orange field in Fig. 22); 2) mildly silica-undersaturated, from the Mercato to the Pompeii (79 AD) eruptions (10 to $2 \mathrm{ka}$; orange field in Fig. 22); 3) highly silica-undersaturated, younger than Pompeii eruption (red fields in Fig. 22). Variations in the content of some major and trace elements as well as element/element ratios (e.g. Th/Ta and $\mathrm{Nb} / \mathrm{Zr}$ ) are consistent with this division (Cioni et al., 1997; Ayuso et al., 1998), although the general incompatible trace element patterns remain similar among rocks of these three periods of activity (Fig. 22). 

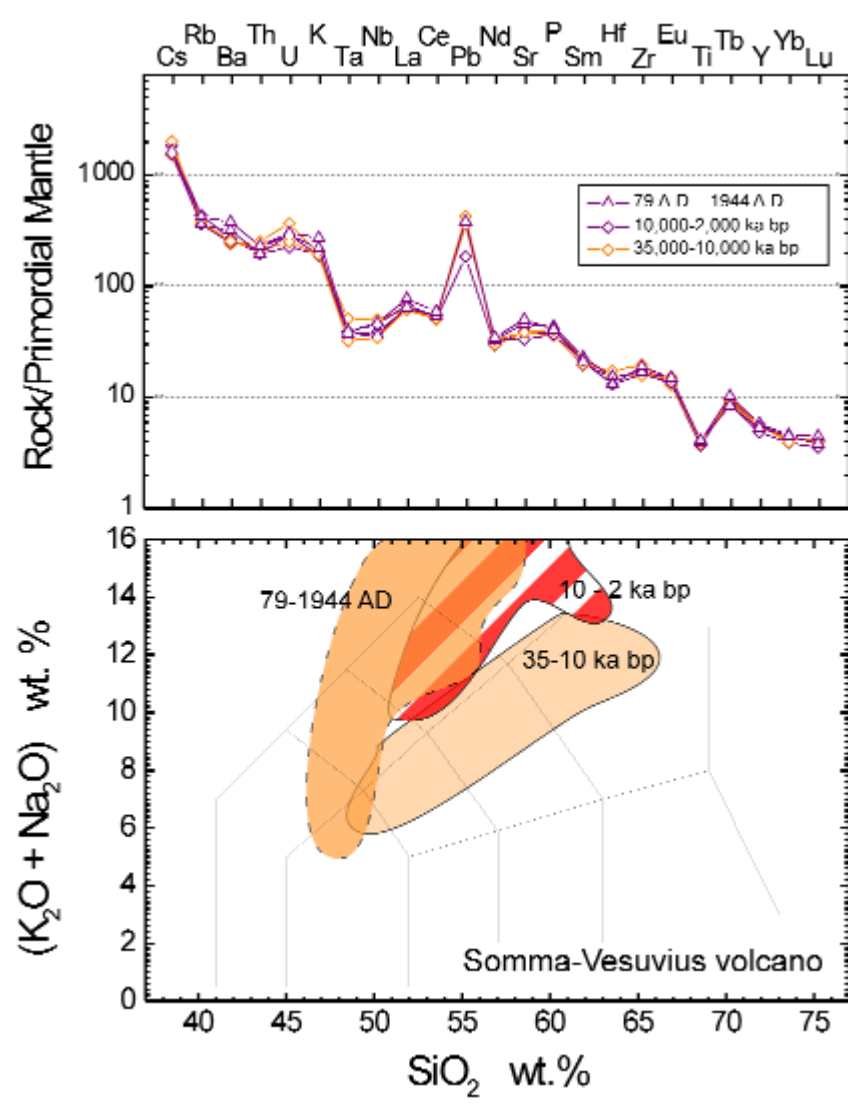

Fig. 22 - Total Alkali Silica classification diagram (Le Maitre et al., 2002) for Somma-Vesuvius volcanic rocks of the last $35 \mathrm{ka}$. Data from Santacroce et al. (1983, 1993, 1994); Joron et al. (1987), Civetta et al. (1991), Civetta \& Santacroce (1992); Villemant et al. (1993); Cioni et al. (1997); Ayuso et al. (1998); Conticelli et al. (2002, 2007, 2015a); Di Renzo et al. (2007); Avanzinelli et al. (2008); Conticelli's unpublished data, Melluso's unpublished data. Redrawn after Cioni et al. (2008) and Conticelli et al. (2010a).
Isotopic variations, however, although showing relatively wide ranges $(87 \mathrm{Sr} / 86 \mathrm{Sr}=0.70699$ to $0.70803 ; \delta 180=7.3$ to $10.2 \%$; $206 \mathrm{~Pb} / 204 \mathrm{~Pb}=$ 18.947 to $19.178 ; 207 \mathrm{~Pb} / 204 \mathrm{~Pb}=15.617$ to $15.769 ; 208 \mathrm{~Pb} / 204 \mathrm{~Pb}=$ 38.915 to $39.435 ; 143 \mathrm{Nd} / 144 \mathrm{Nd}=0.51228$ to 0.51251 , Ayuso et al., 1998; Avanzinelli et al., 2008; Conticelli et al., 2015a, and references therein) do not follow this threefold division.

Previous papers (Civetta \& Santacroce, 1992; Santacroce et al., 1994; Cioni et al., 1997) have shown that the compositional variability of Vesuvius magmas resulted (at least for the last $4 \mathrm{ka}$ ) from magma evolution processes reflecting irregularly spaced periods of open and obstructed conduit conditions of a plumbing system, and characterised by the constant presence of shallow magma chambers, periodically supplied by discrete, deep, mafic magma batches (see following section). The compositional spectrum found in melt inclusions indicates that none of the compositions found among igneous rocks at Somma-Vesuvius are truly primitive (Marianelli et al., 1995). A change from trachy-basaltic to tephritic occurred between the AP1 and 79 AD eruptions, reflecting in the changes recorded by highly evolved magmas (from trachyte and phonolite to leucititic phonolite). Magma recharge to the shallow reservoirs together with carbonate assimilation and "mixing and mingling with previously contaminated magmas at shallow depths and/or by entrapment of crystal mush generated during previous magma storage in the crust" has been proposed by Piochi et al. (2005) to explain the change in composition with time of Vesuvius magmas.

1) Slightly silica-undersaturated (to saturated) magmas (light orange field in Fig. 22) are made up by most of the scoriae and feeding dikes of the Somma, the lavas of parasitic cones of Lagno di Pollena (Fig. 20), and by the two older large eruptions related to Somma-Vesuvius activity: the subplinian, 19,000 yr B.P. "Greenish Pumice" and the 
Plinian, 22,000 yr B.P. "Pomici di Base". These last two eruptions are trachytic and highly evolved with higher silica and lower alkali contents with respect to those of the Somma strombolian activity. As a whole the geochemical features of these rocks are coherent with evolutionary trends of trachy-basaltic liquids initially driven by crystallization of mafic phases and plagioclase and later involving K-feldspar fractionation.

2) Mildly silica - undersaturated magmas (red strips field in Fig. 22) are represented by the pyroclastic products of three Plinian eruptions (79 AD "Pompeii", 3,900 yr B.P. "Avellino" and 8,900 yr B.P. "Mercato") and at least six other explosive eruptions that occurred between the Avellino and Pompeii events (AP1 to AP6 of Andronico \& Cioni, 2002). In contrast to the Mercato deposits, which are characterised by a strong compositional homogeneity all along the whole eruptive sequence, the products of the other eruptions of this group present significant compositional variations, from the most evolved products at the base to the least evolved toward the top. The Mercato and Avellino eruptions (first-erupted white pumice) produced the most evolved products of Somma-Vesuvius Volcano ( $\mathrm{CaO}<2.0 \%, \mathrm{Nb}>100 \mathrm{ppm} ; \mathrm{Zr}>700 \mathrm{ppm}$ ).

3) Silica - undersaturated magmas (orange field in figure 22) are represented by the overall products erupted after the 79 AD Pompeii eruption. The most relevant geochemical features of these rocks are their lower silica and higher alkali contents with respect to rocks with comparable evolution from the older two groups, as well as their very high $\mathrm{Sr}$ and $\mathrm{Ba}$ contents. These features are consistent with evolutionary trends (mostly fractionation within a periodically supplied magma chamber) of tephritic liquids dominated by crystallization of leucite and mafic minerals, and characterized by minor role of plagioclase and the absence of $\mathrm{K}$-feldspar fractionation.

Magma chambers

The presence of magma chambers at crustal levels at Somma-Vesuvius Volcano is strongly suggested by the occurrence, in many of the past plinian and subplinian eruptions, of thermometamorphic and skarn ejecta of carbonatic nature (Barberi \& Leoni, 1980). Cioni et al. (1997) suggested that magma chambers associated with these eruptions had different volumes, ages and compositional layering, and were all located within the carbonate basement, at a pressure of about 150-200 MPa (Cioni et al., 1997; Cioni, 2000). These magma chambers were fed by discrete, deep, mafic magma batches (possibly $5-10 \times 10^{6} \mathrm{~m}^{3}$ with a magma supply rate in the range $1-5 \times 10^{6} \mathrm{~m}^{3} \mathrm{y}^{-1}$, Santacroce et al., 1994). The change from potassic trachy-basalt to tephrite, which occurred during the period between the Avellino and the Pompeii pumice eruptions, accompanies the important compositional change recorded by highly evolved magmas (phonolite to leucititic phonolite). 
During the 1631-1944 period, characterised by persistent activity under open conduit conditions, a shallow reservoir ( $<3 \mathrm{~km}$ depth; Fulignati et al., 2004, 2005) was continuously tapped through effusive and mild to violent strombolian activity. The periodic arrival in the shallow reservoir of mafic magma from a deeper region is recorded in the thermal and compositional history of high-T crystals (Cioni et al., 1997; Marianelli et al., 2005). Data from fluid and melt inclusions (Belkin \& De Vivo 1993; Marianelli et al., 1999, 2005; Fulignati et al., 2004) reveal the polybaric evolution of the erupted products, suggesting an 8-12 km deep provenance for tephrite to phonolitic-tephrite magmas feeding the shallow reservoirs. Magma transfer to the shallow system resulted in eruptions whose dynamics episodically induced the nearly complete emptying of the reservoir. Activity resumed after short quiescent periods, possibly reflecting the time needed for the restoration of the shallow plumbing system. The present quiescence, lasting since 1944, departs from this pattern, and a generally accepted conclusion is that the 1944 AD eruption marked the transition to obstructed conduit conditions.

The present state of the volcano has been investigated through active seismic (Zollo et al., 1998; Auger et al., 2001; Del Pezzo et al., 2006), teleseismic (De Gori et al., 2001), magnetotelluric (Di Maio et al., 1998; Patella \& Mauriello, 1999) and integrated (gravity, magnetic and self-potential data, Iuliano et al., 2002) tomographies. All these data show a high velocity anomaly below the crater area, extended down to 5-6 km and interpreted as a rigid, high density residue left by the crystallisation of magma filling the shallow plumbing system and "plugging the chimney" (Iuliano et al., 2002). However, the spatial resolution of all tomographic methods performed at Vesuvius does not exceed $300-500 \mathrm{~m}$, being unable to reveal the presence of high aspect ratio, prolate (cigar-like) magma bodies with volume $<0.1-0.2 \mathrm{~km}^{3}$. All these data seem to rule out the presence of a large magma chamber at the same depth as those, in the past, characterised the reawakening of the volcano. A possible zone of magma accumulation is suggested by seismic data at 8-10 km depth (Auger et al., 2001; 11-15 km according to De Natale et al., 2006), mainly constrained by reflected-converted seismic waves. This depth is roughly consistent with the pressure estimated for the mafic melts feeding shallow magma chambers during open periods (Marianelli et al., 1995, 2005) and with the experimental petrology results of Scaillet et al. (2008b).

The record of the explosive activity

The pyroclastic products of Somma-Vesuvius have been widely studied in the past. In the most recent geological map of the volcano (Fig. 23) more than 40 explosive events have been distinguished, recording 
complex activity characterised by eruptions with a variable Volcanic Explosivity Index (VEI) as well as by very different eruption styles. A review of published data and of a large dataset of unpublished stratigraphic and compositional data was used by Cioni et al. (2008) to address the problem of classification of the different types of eruption and to discuss the general behaviour of the volcano in terms of time frequency of the events, magnitude vs. intensity relationships, and intensity vs. length of the repose time.

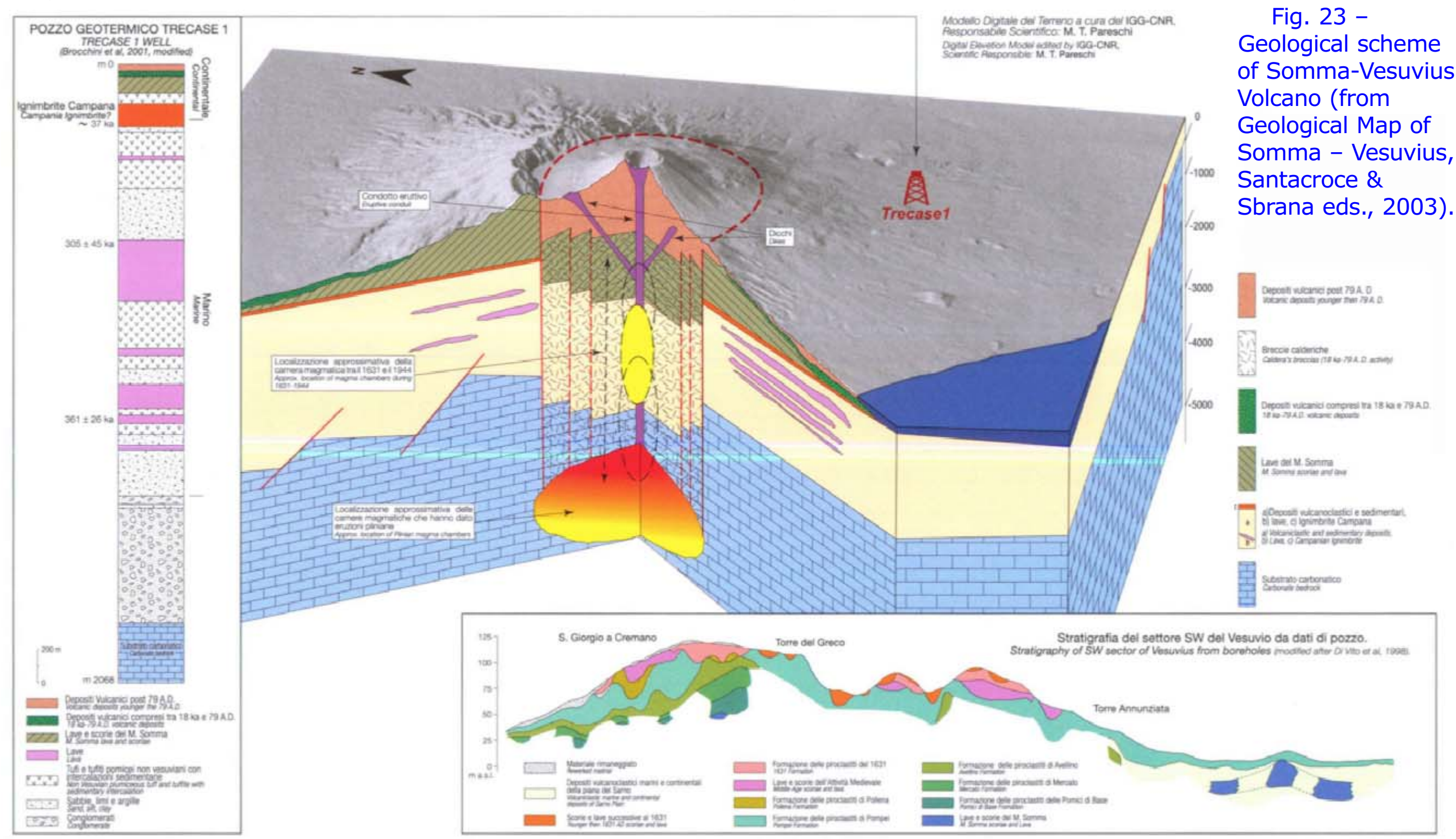


The wide spectrum of eruption styles, as recorded in the pyroclastic successions, can be divided in a set of eruption types each characterised by specific eruptive parameters:

- plinian eruptions

- subplinian eruptions (further subdivided in subplinian I and subplinian II)

- violent strombolian eruptions

- ash emission events

- prolonged mild strombolian activity

The distinction between the different types can be made both on the general features of their deposits and on the physical parameters estimated from the deposits themselves (see table below).

\begin{tabular}{|c|c|c|c|c|c|c|c|c|c|c|c|}
\hline Eruption Type & $\begin{array}{c}\text { Repose } \\
\text { (yr) }\end{array}$ & $\begin{array}{l}\text { Volume } \\
\mathbf{k m}^{3}\end{array}$ & VEI & $\begin{array}{l}\text { Peak MDR } \\
\left(\mathrm{kg} \mathrm{s}^{-1}\right)\end{array}$ & $\begin{array}{l}\text { Col. } \\
\text { Height } \\
(\mathbf{k m})\end{array}$ & PDC & Composition & $\begin{array}{c}\mathrm{SiO}_{2} \\
\text { (wt. \%) }\end{array}$ & $\begin{array}{l}\text { alkali } \\
\text { (wt.\%) }\end{array}$ & $\begin{array}{c}\mathrm{H}_{2} \mathrm{O} \\
\text { (wt.\%) }\end{array}$ & $\begin{array}{l}\mathrm{CO}_{2} \\
\mathrm{ppm}\end{array}$ \\
\hline \multirow{2}{*}{ Plinian } & \multirow{2}{*}{$10^{2}-10^{3}$} & \multirow{2}{*}{$10^{0}-10^{1}$} & \multirow{2}{*}{5} & \multirow{2}{*}{$10^{7}-10^{8}$} & \multirow{2}{*}{$>20$} & \multirow{2}{*}{ yes } & trachyte & $54-61$ & $8-13$ & no data & no data \\
\hline & & & & & & & phonolite - tephriphonolite & $54-62$ & $11-16$ & $5-6$ & $0-1000$ \\
\hline Sub-Plinian I & $10^{2}$ & $10^{-1}-10^{0}$ & 4 & $10^{7}$ & $15-20$ & yes & $\begin{array}{l}\text { tephriphonolite - } \\
\text { phonotephrite }\end{array}$ & $48-52$ & $8-16$ & $\begin{array}{c}2.5 \\
\text { (felsic) } \\
<5 \\
\text { (mafic) }\end{array}$ & $\begin{array}{l}0-100 \\
1000\end{array}$ \\
\hline Sub Plinian II & $10^{2}$ & $10^{-2}-10^{-1}$ & 3 & $10^{6}-10^{7}$ & $10-15$ & minor & $\begin{array}{l}\text { tephriphonolite - } \\
\text { phonotephrite }\end{array}$ & $48-54$ & $8-11$ & no data & no data \\
\hline Violent Strombolian & $10^{1}-10^{2}$ & $10^{-3}-10^{-1}$ & $3-2$ & $10^{5}-10^{6}$ & $5-10$ & $\begin{array}{c}\text { minor } \\
\text { avalanching }\end{array}$ & tephrite - phonotephrite & $48-52$ & $6-12$ & $2-5$ & $0-3500$ \\
\hline $\begin{array}{l}\text { Continuous ash } \\
\text { emission }\end{array}$ & $10^{1}-10^{2}$ & up to $10^{-}$ & $3-2$ & $<10^{5}$ & $<5$ & no & $\begin{array}{l}\text { tephriphonolite - } \\
\text { phonotephrite }\end{array}$ & $49-51$ & $9-12$ & $1-2$ & $0-1000$ \\
\hline Mild Strombolian & $10^{0}-10^{1}$ & $10^{-3}$ & 2 & & & no & tephrite - phonotephrite & $47-49$ & $7-11$ & no data & no data \\
\hline
\end{tabular}

The Frequency of the events is shown in the chronogram of Fig. 21, which depicts a volcano characterised by important changes in its eruption frequency, magnitude and intensity. These changes are also associated with the changes in magma composition in terms of alkali and silica content (Fig. 22). There is no simple relationship between eruption age and type. However, most of the eruptions with VEI $\leq 3$ are present in the activity of the last 3.9 ka. The four Plinian events (and the related phases of caldera collapse) have occurred at time intervals whose length decreases with age, from the 13 ka separating the "Pomici di Base" and Mercato eruptions to the 2.5 ka interval between the Avellino and Pompeii eruptions (the intervals are derived from the calibrated ages of the eruptions, as given in Santacroce et al., 2008). In addition, following the "Avellino Pumice" eruption, an increase in the frequency 
of activity occurred, with several explosive eruptions of lower magnitude and intensity punctuating the interval between the Avellino and Pompeii events. After 79 AD Pompeii eruption the activity increased its frequency, and the stratigraphic record shows periods of open-conduit activity alternating with pauses interrupted by explosive events. On the whole, the magnitude of the eruptions has been roughly decreasing with time while, since 3.9 ka BP, their frequency has been increasing.

The difference in the number of events before and after the Avellino pumice eruption poses some questions about the reliability and completeness of the stratigraphic record. However, the reconstructed sequence of the SommaVesuvius pyroclastic activity has to be considered as a nearly complete picture of explosive activity of the volcano, not suffering any major bias related to intrinsic incompleteness of the dataset, at least for VEI $>3$ explosive activity.

Data of magnitude and intensity of Somma-Vesuvius are now available for about 20 explosive eruptions. The peak Mass Discharge Rate (MDR, in $\left.\mathrm{kg}^{*} \mathrm{~s}^{-1}\right)$ and the volume $\left(\mathrm{V}\right.$, in $\left.\mathrm{km}^{3}\right)$ can be used as proxies for intensity and magnitude respectively, as suggested in Pyle et al. (2000). When plotted (Fig. 24), the two parameters exhibit a power law correlation, with an $\mathrm{R}$ coefficient of 0.55 . With these data, however, a sigma-shaped curve can also be fit (Fig. 24). The main problem in establishing a correlation is actually related to the gap existing for intermediate values of magnitude and intensity ( $\mathrm{V}$ between $10^{-2}$ and $10^{-1}$ $\mathrm{km}^{3}$, MDR between $10^{4}$ and $10^{6} \mathrm{~kg}^{*} \mathrm{~s}^{-1}$ ). On a general basis, it can be assumed that intensity increases with magnitude up to the category of plinian eruptions. It is worth noting, however, that this correlation does not hold for the four plinian eruptions.

The volume vs. MDR diagram of figure 24 represents a first attempt to systematize the past $20 \mathrm{ka}$ of activity of the volcano. Possible problems on the data can be related to:

- The plotted intensity values refer to the peak MDR, a value not representative of the whole eruption, especially for long-lasting, unsteady events;

- Eruption rate is difficult to estimate for those eruptions characterised by pyroclastic flow activity, during which the flow rate could be higher than that estimated for the convective plinian column;

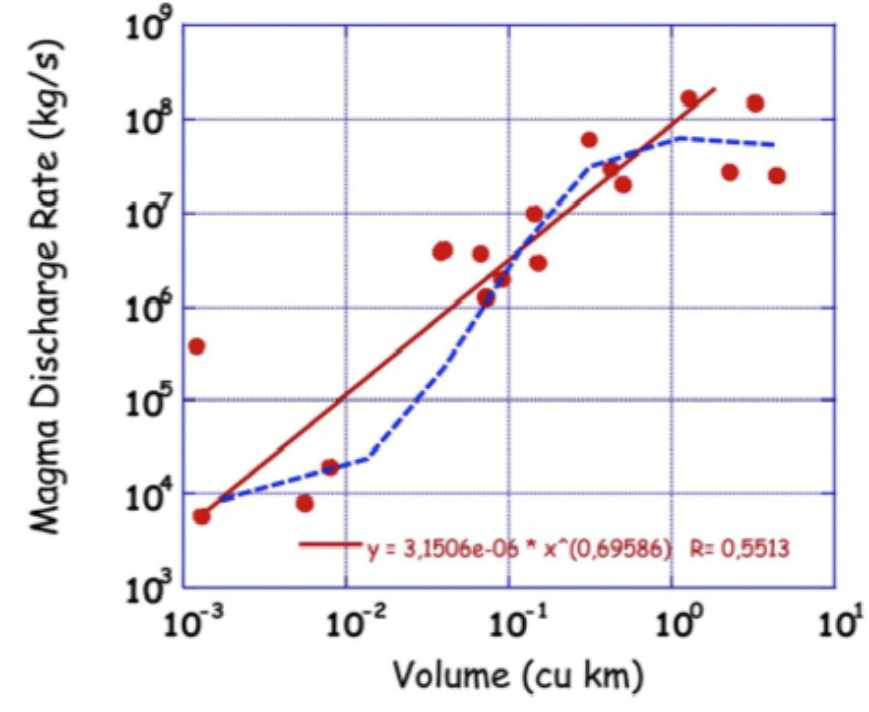

Fig. 24 - Log-log diagram showing volume vs. Peak MDR (as proxies for magnitude and intensity respectively) of selected eruptions of SommaVesuvius. 
- Volume estimation especially suffers from problems related to the quantification of the distal products with respect to the proximal and medial products, which are easily recognisable and measurable (Bonadonna et al., 1998). This resulted in a different distribution error depending upon the style of the eruption, being the error on high-intensity eruptions larger than that for low-intensity ones.

Magnitude vs. Repose time - The systematic revision of the data on past activity provides further information

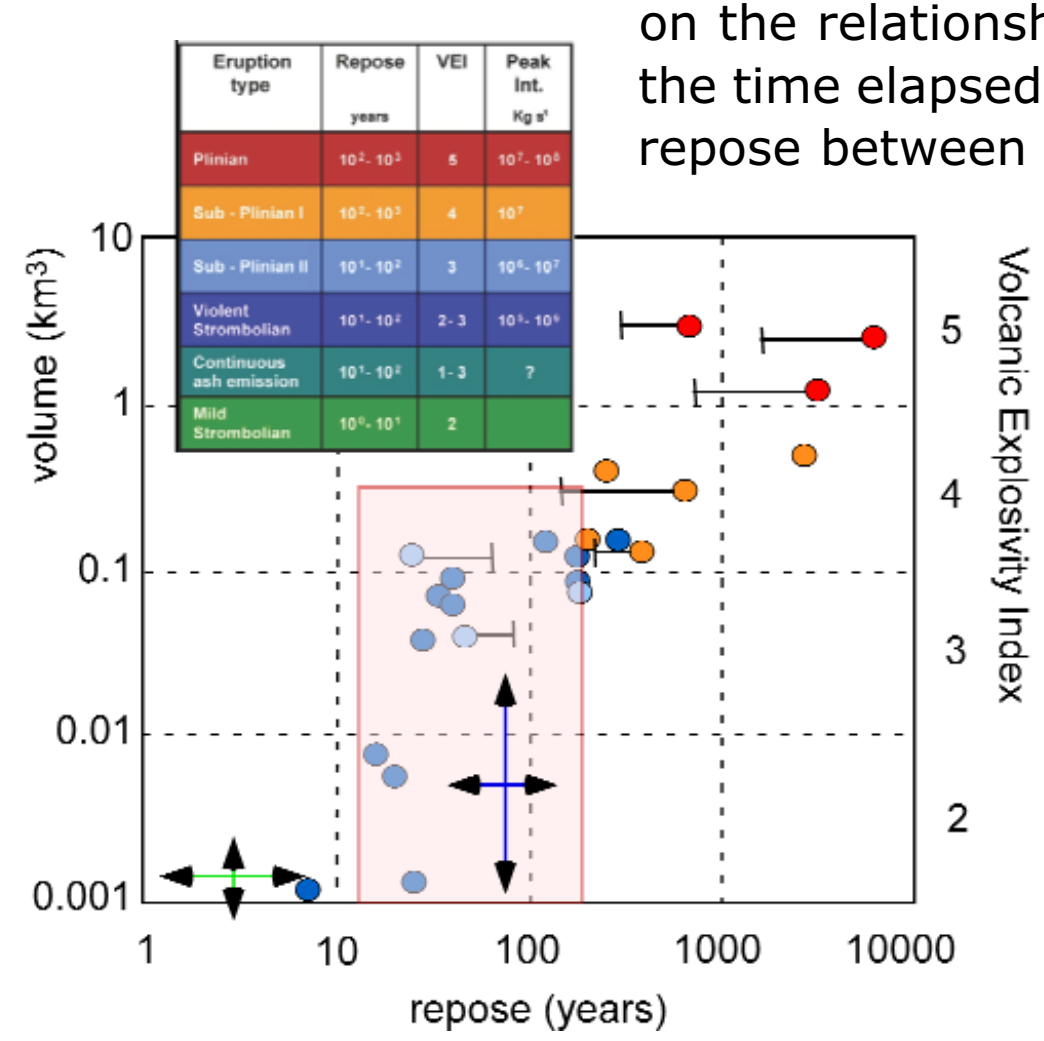

Fig. 25 - Apparent repose vs. magnitude of the eruption of the Somma-Vesuvius. The main physical parameters associated to each eruption type are shown in the inset. The red dashed window shows that a large variability in eruptive styes is associated to repose times of the order of 100 years, similar to the present one (redrawn after Cioni et al., 2008). of the products, the deposits of several eruptions have been unequivocally recognized, and the repose time before each eruption is represented by the difference in age between two overlapping deposits. In this case, we should speak in terms of "apparent repose time", as it is highly probable that in the case of activity characterised by variable intensity of the eruptions, only some of these events, e.g. those with VEI $>2$, are clearly recorded in the stratigraphic sequence. Conversely, when a set of historical data from direct observation is available, it is possible to deal with a "real" repose time. In the case of Somma-Vesuvius, this can be done for the post 1631 AD period, during which the activity of the volcano was clearly dominated by open conduit conditions and characterised by decade-lasting eruptive periods with mild to low intensity effusive and explosive phases often culminated in larger, violent strombolian eruptions. To compare the length of repose time between eruptions during these different periods we consider in both cases an "Apparent repose time", which is the difference between the age of two consecutive eruptions whose deposits can be detected in the field. Using this methodology, the periods of 
open conduit conditions result in a sequence of a few major events with a VEI not lower than 2.

A positive correlation between the length of repose and magnitude of the eruption is clearly indicated by the data reported in figure 25. This was interpreted by Santacroce (1983) as evidence of a roughly constant deep magma feeding to a shallower magma storage system. As already discussed, there is scatter between the size of an eruption and its intensity, introducing a larger uncertainty when looking at the possible correlation between repose and eruption style. The length of the apparent repose is well correlated with eruption size for the most intense eruptions (plinian and subplinian I), while the correlation is poorer for eruptions of intermediate size and intensity (Fig. 25). In particular, a large variability in the magnitude and eruption style of the past eruptions is apparent for a window of repose time from dozens to hundreds of years.

\section{The Stops of the 1 st day}

The itinerary starts from Naples taking the pay-tool highway "A3". Take the Exit at Torre del Greco and then follow, immediately out of the highway, the signs to the summit of Monte Vesuvio. Then you will drive along the southern slopes of Somma-Vesuvius and inside the Mt Somma caldera. Climb along the Vesuvius slopes up to the crater
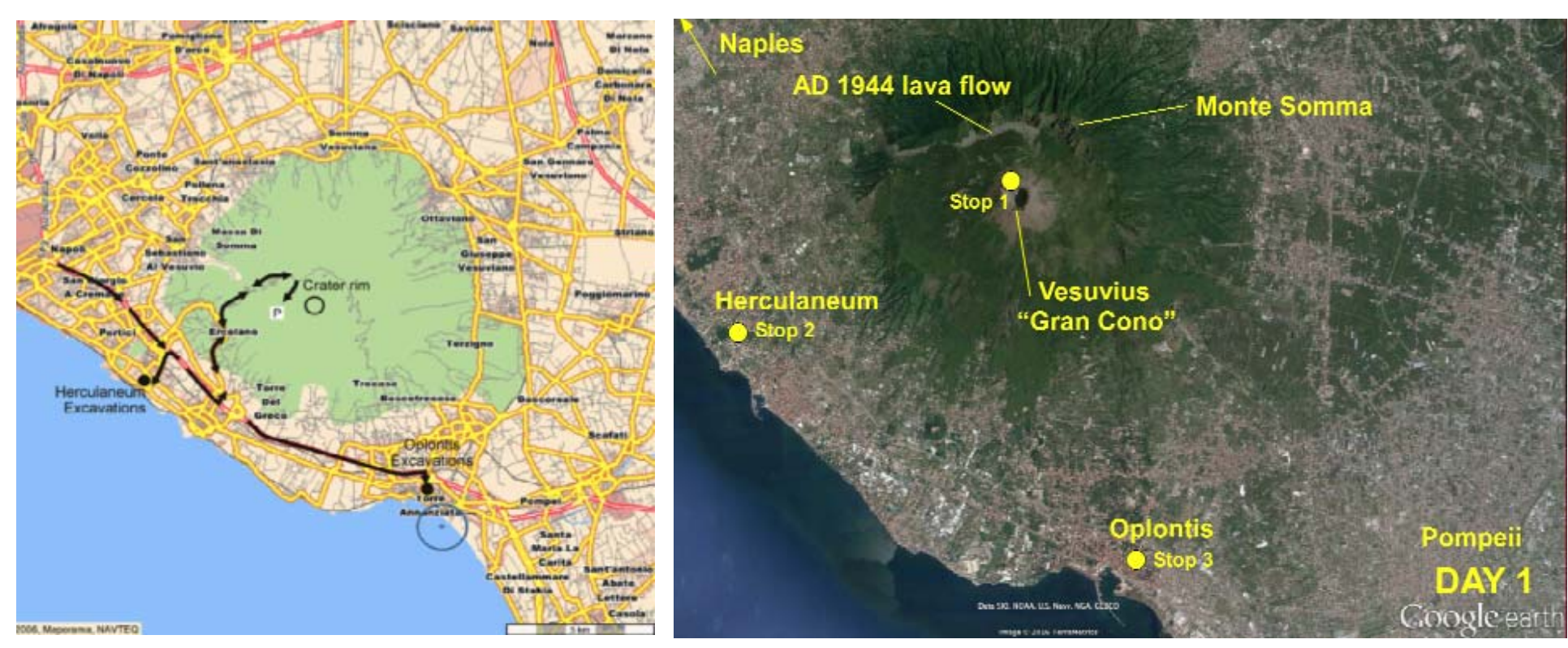

Fig. 26 - Maps showing the location of the three stops at Somma-Vesuvius Volcano and the main routes around the volcano. rim. The second part of the day will be dedicated to the visit of two archaelogical sites, the Villa di Poppea in Oplontis, and the Herculaneum excavations (Fig. 26). During the visit to the two sites, destroyed by the 79 AD Pompeii eruption, you will address the main problems related to Vesuvius explosive activity, and the different effects on inhabited areas related to pyroclastic fallout and pyroclastic flow activity. 


\section{STOP 1.1: the Somma caldera and the Vesuvius crater}

The last part of the main road to the crater runs inside the Somma-Vesuvius caldera, a polyphase depression formed by repeated collapses following the main plinian and subplinian eruptions (Fig. 20). The caldera walls, made up mostly by scoriae and lapilli of the early Somma activity, are steep (Fig. 27) and cut by dykes (Fig. 28), which are difficult to be attributed to one of the three epochs of activity although most of the parasitic vents belong to the Somma epoch and were possibly fed by these dikes.

The Valle dell'Inferno, the annular depression separating the caldera walls from the Vesuvius cone, is partially filled by the lava flow of the last eruptive event of the volcano, occurred on March 1944 AD.

Once left the vehicles on the main square in front of the entrance of the footpath to the crater, at $1014 \mathrm{~m}$ a.s.I., a light hike through a pathway within the red and grey scoriae of the last 2,000 years of activity drive to the edge of crater.

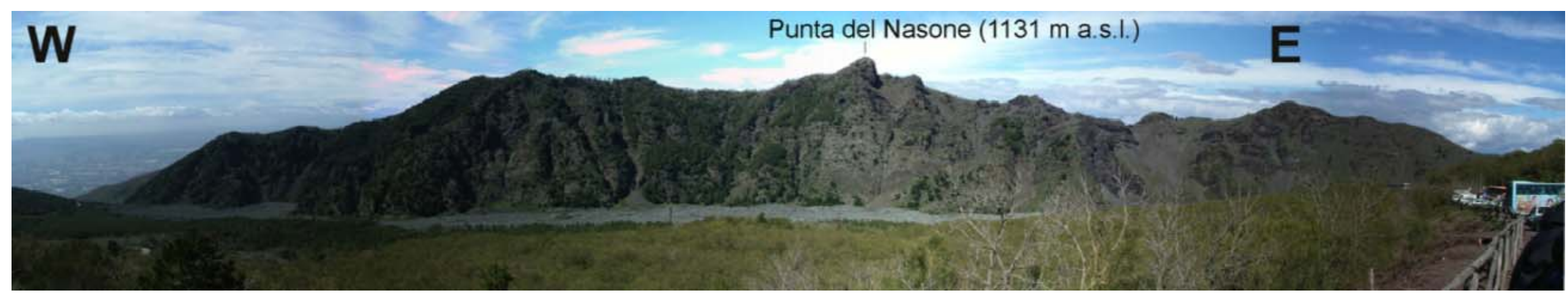

Fig. 27 - Panoramic view of the Somma polygenetic caldera. The grey strip at the base of the caldera walls is the 1944 lava flow (Photo: R. Cioni).

At the fourth turn of the track $\left(40^{\circ} 49^{\prime} 37^{\prime \prime} \mathrm{N}-14^{\circ} 25^{\prime} 36^{\prime \prime} \mathrm{E}\right)$ the lookout offers the unique opportunity to observe the vent at the base of the Vesuvius cone from which the main tongue of the 1944 AD lava flows poured out. Once reached the western rim of the Vesuvius crater (i.e., Gran Cono), at 1150 m. a.s.I. (4049'21"N $14^{\circ} 25^{\prime} 21^{\prime \prime} \mathrm{E}$ ) it is possible to observe the inner side of crater (Fig. 29).

The current crater formed as a consequence of the destruction of the lava platform, and possibly of a small collapse, which occurred during the last explosive phases of the 1944 AD eruption. 
The sequence of thin lava flows, representing the different phases of lava platform formation, is well visible on the steep northern and eastern inner walls of the current crater. This left a much wider crater (part of the rim is still visible) which was slowly filled with lava until 1944, when a central conelet was approximately at the height of the north-west rim. On top of the rim there is a thick lava flow (1944 AD) covered by scoriae and lapilli of the last phase of the eruption. To the East an apparent fracture is visible, which actually marks

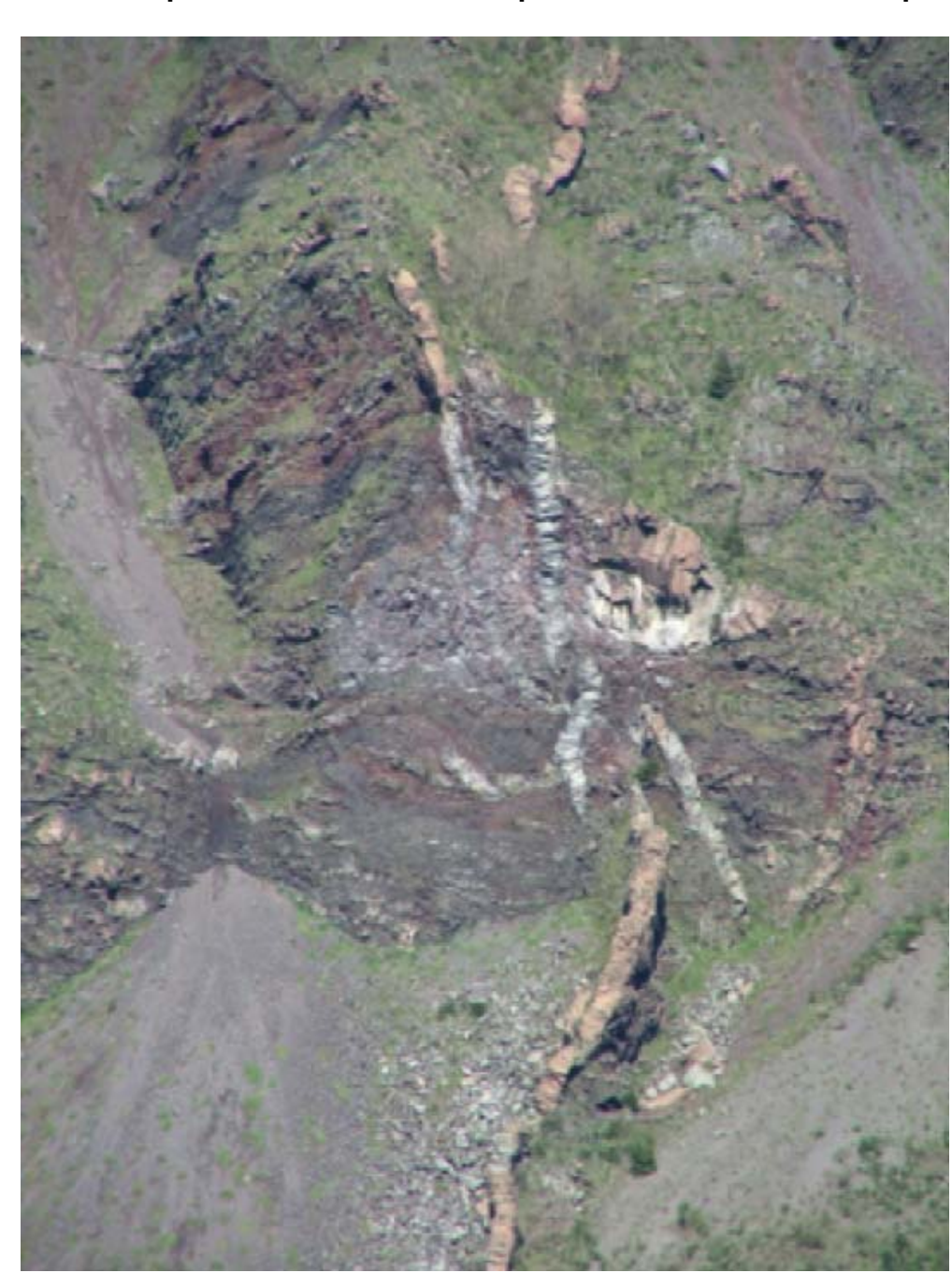

Fig. 28 - Dikes cutting the internal wall of the Somma polygenetic caldera rim (Photo: R. Cioni). the contact between the lava flows of the 1913-44 AD crater and those of the 1872-1906 AD crater.

Further on along the rim of the crater, one can observe the whole extent of the southern part of the volcano and, during days with good visibility, it is possible to see the entire gulf of Naples, from the Sorrento peninsula to Cape Miseno, Procida and Ischia, as well as the ancient town of Pompeii destroyed by the famous 79 AD eruption.

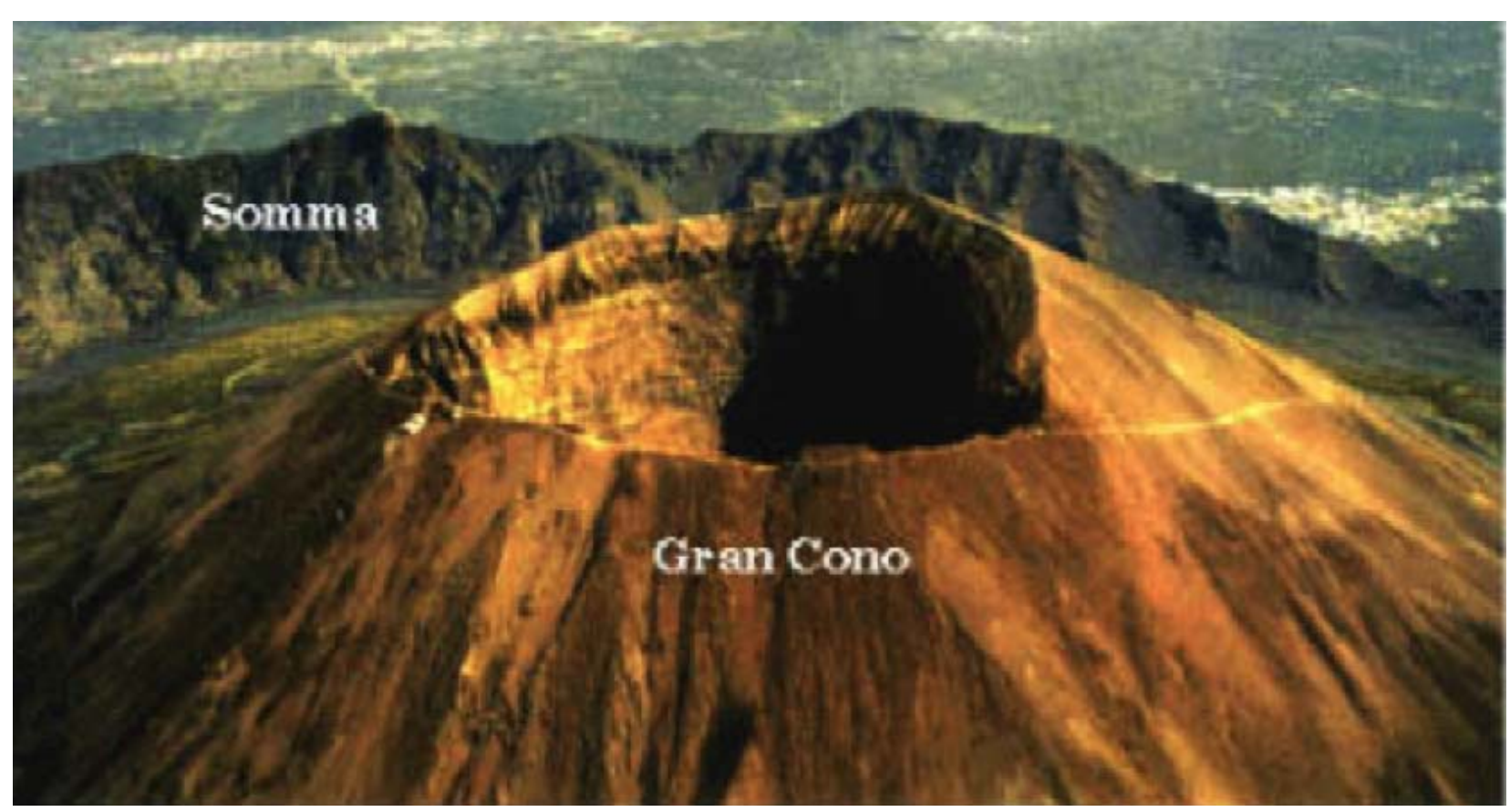

Fig. 29 - View from SW of the Vesuvius cone and the Somma caldera. http://vulcan.fis.uniroma3.it/vesuvio. 
On the way down to present day Pompei town, some kilometres away, you will encounter the modern Torre Annunziata village that was built over the ancient Oplontis, covered by the pyroclastic deposits of the 79 AD Pompeii eruption. The Villa di Poppea (the Emperor Nero's wife) is the most important archaeological excavation at Oplontis $\left(40^{\circ} 45^{\prime} 27^{\prime \prime} \mathrm{N}-14^{\circ} 27^{\prime} 08^{\prime \prime} \mathrm{E}\right)$. The Villa di Poppea was destroyed by the pumice fallout of the plinian $79 \mathrm{AD}$ eruption. Along the exterior of the Villa, there is a nearly complete sequence of the fallout deposits and of the pyroclastic flows related to partial column collapses which repeatedly occurred during the plinian phase of the eruption (Fig. 30).

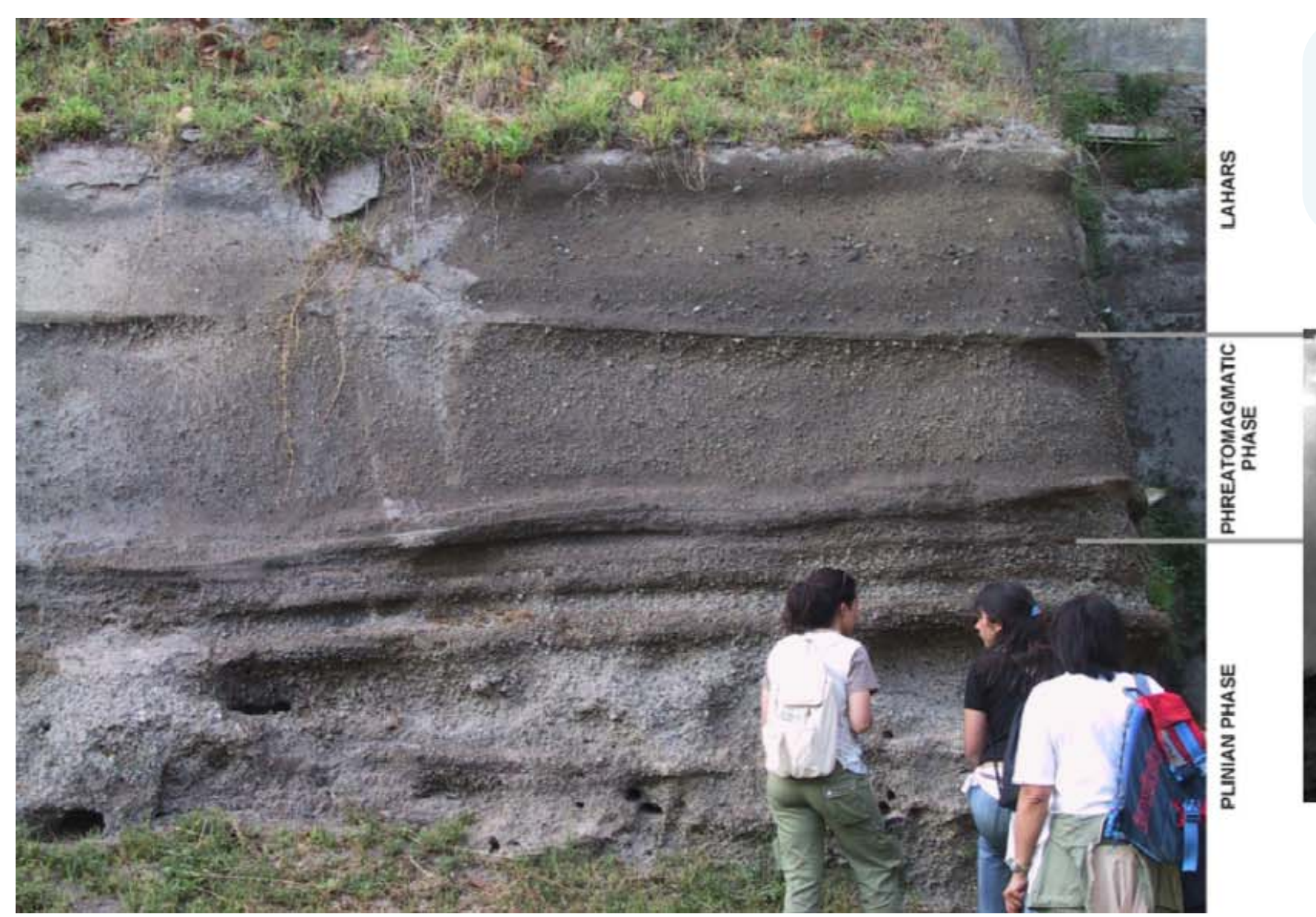

Fig. 30 - At left hand side, the pyroclastic sequence of $79 A D$ eruption at Oplontis excavations. Below, The summit cone-let on a lava platform filling the summit crater in the '30ties (http://vulcan.fis.uniroma3.it/vesuvio).

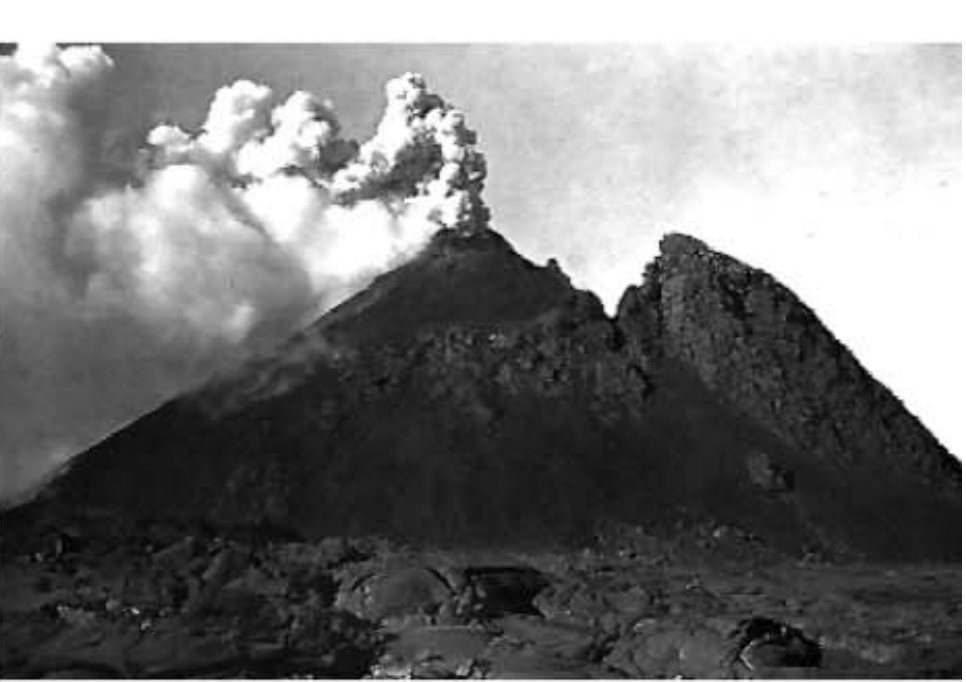




\section{The 79 AD Pompeii eruption}

On 24 August $79 A D$, Vesuvius erupted violently, depositing ash and pumice (1.5 km DRE, Cioni et al., 1999) downwind for thousands of kilometers and dispersing Pyroclastic Density Currents (PDC) radially around the volcano (c. $0.30 \mathrm{~km}^{3} \mathrm{DRE}$, Cioni et., al 1999) that destroyed and buried several Roman towns (Fig. A). Sigurdsson et al. $(1982,1985)$ proposed a chronological scheme for the eruption based on the eyewitness accounts of Pliny the Younger. This scheme was incorporated into a stratigraphic framework by Cioni et al., (1992; 1995), who divided the deposits into eight eruption units and three phases: the opening phreatomagmatic phase (EU1), the Plinian magmatic phase (EU2 and EU3), and the final phreatomagmatic, caldera-collapse phase that was accompanied by progressively increasing involvement of external water (EU4 to EU8). Over the course of the eruption, first white phonolitic pumice (EU1 and EU2), then gray tephri-phonolitic pumice (EU3-EU8), were erupted. The presence of these two different juvenile compositions has been interpreted as evidence of syn-eruptive magma-mixing in a zoned chamber (e.g., Sigurdsson et al., 1990; Cioni et al., 1995; Marianelli et al., 1995; Cioni, 2000). In this model, the white pumice is derived from the uppermost portion of the reservoir which contained a phonolitic magma with moderate compositional and isotopic layering. The gray pumice has been interpreted as the product of variable amounts of syneruptive mingling and mixing between this phonolitic melt and a crystal-poor, homogeneous, phono-tephritic magma that never erupted in an unmodified state. The influence of mixing during the eruption is seen in the $\mathrm{MgO}$ and $\mathrm{Sr}$ contents of the erupted pumice (Figs $\mathrm{Bc}, \mathrm{Bd}$ ). During the caldera-forming phase, variable amounts of cognate crystal-rich material were incorporated from the collapsing walls of the chamber and residual

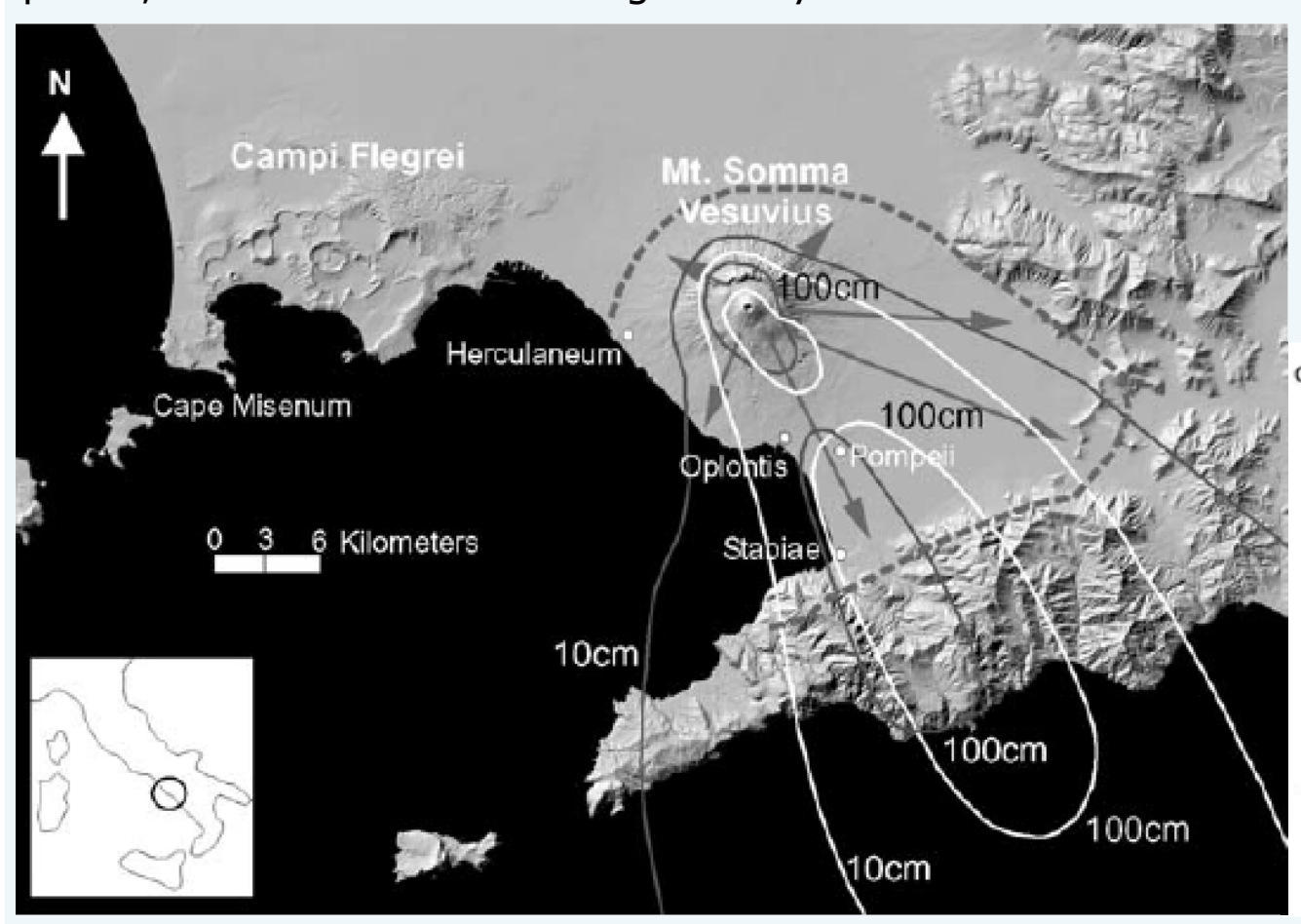
small pockets of phonolitic magma were tapped from near the roof of the chamber (Cioni et al., 1995).

Left: Dispersion of fall EU2 (white lines) and EU3 fall deposits (grey lines). Dashed grey line represents the area invaded by EU4-7 pyroclastic flows (from Gurioli et al., 2005).

Below: schematic merged stratigraphy of the $79 \mathrm{AD}$ eruption cropping out in the southern sector of Vesuvius along the main dispersal axis of the Plinian fall-out (grey arrow in the map beside (from Gurioli et al., 2005)
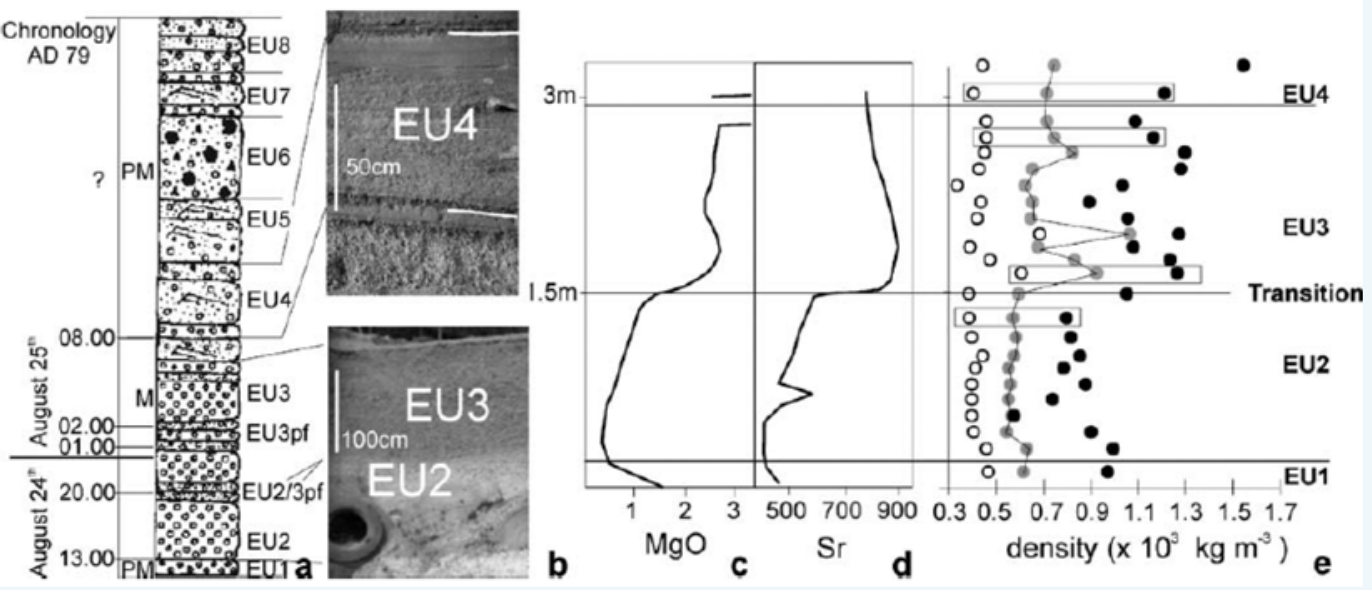
The ancient city of Herculaneum $\left(40^{\circ} 48^{\prime} 22^{\prime \prime} \mathrm{N}-14^{\circ} 20^{\prime} 57^{\prime \prime} \mathrm{E}\right)$ is only $7 \mathrm{~km}$ west-south-west of the current crater of Vesuvius (Fig. 31). The ancient town was buried under $20 \mathrm{~m}$ of pyroclastic deposits produced during the 79 AD eruption. The archaeological excavation brought to light only a small portion of ancient Herculaneum because most of it is still under the new town of Ercolano.

According to legend, the town was founded by Hercules, hence the name Herculaneum was originally a Greek city showing the typical orthogonal scheme of roads, NS and EW directed

Fig. 31 - The Monte Somma and the Vesuvius cone (Gran Cono) on the back of the Herculaneum excavations from the waterfront (Photo: R. Cioni).

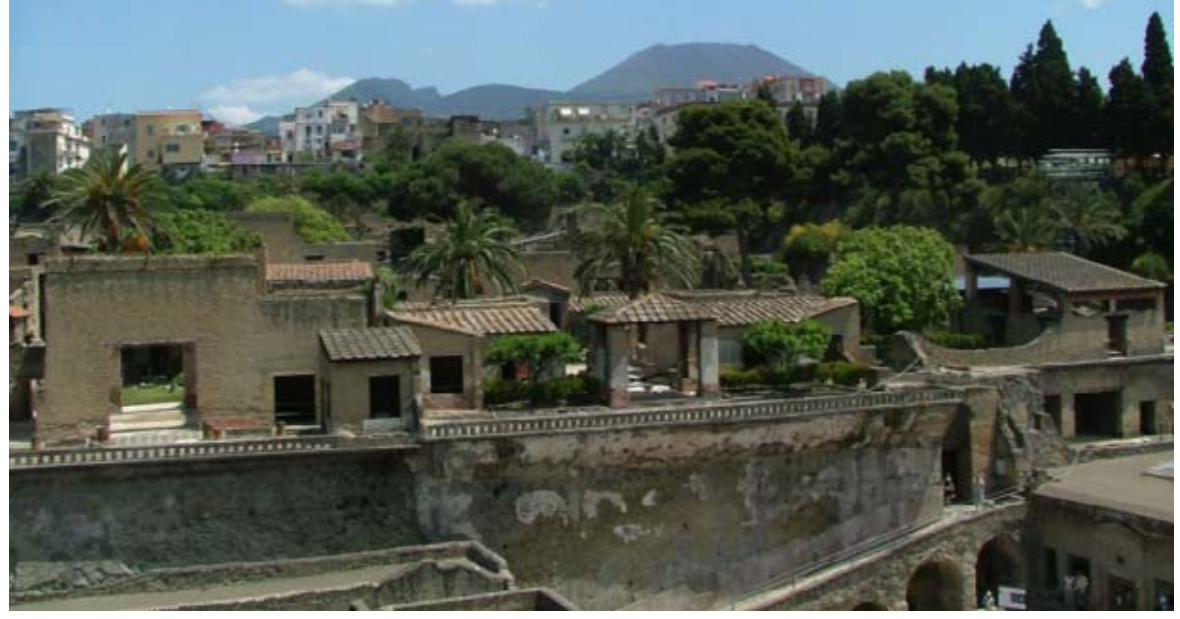
(respectively "cardo" and "decumanus") forming equal city blocks ("insulae"). In Roman times the town was a prosperous and luxurious seaside resort was situated on a hill or headland in front of the sea.

Herculaneum was mainly buried under the deposits of pyroclastic density currents, as the town, although very close to the volcano, was outside the main dispersal fan of the fallout deposits (see notes above).

Herculaneum was reached by a dilute pyroclastic flow (EU2/3pf) related to the white-grey pumice transition, 7 hours after the onset of the Plinian phase (Cioni et al., 2000). This flow caused the death of the inhabitants, even though archaeological evidence suggests only limited damage to buildings (Sigurdsson et al., 1985). Two pumice-rich pyroclastic flows (EU3pf1 and EU3pf2), deriving from the partial and final collapse of the Plinian eruptive column, respectively, followed during the night of 25 August.

The largest pyroclastic density current (EU3pf2) totally destroyed and partially buried the town. After 8:00 AM on 25 August, the passage of several phreatomagmatic pyroclastic currents caused the demolition of stillstanding walls and total burial of the town.

As pyroclastic density currents flowed across terrains with significant topographic obstacles, they developed flow variations, which affected not only the loci of deposition but also the depositional facies. This behaviour can be seen in the excavated area of Herculaneum (Fig. 32), where the currents were separated selectively by the presence of the town buildings. 


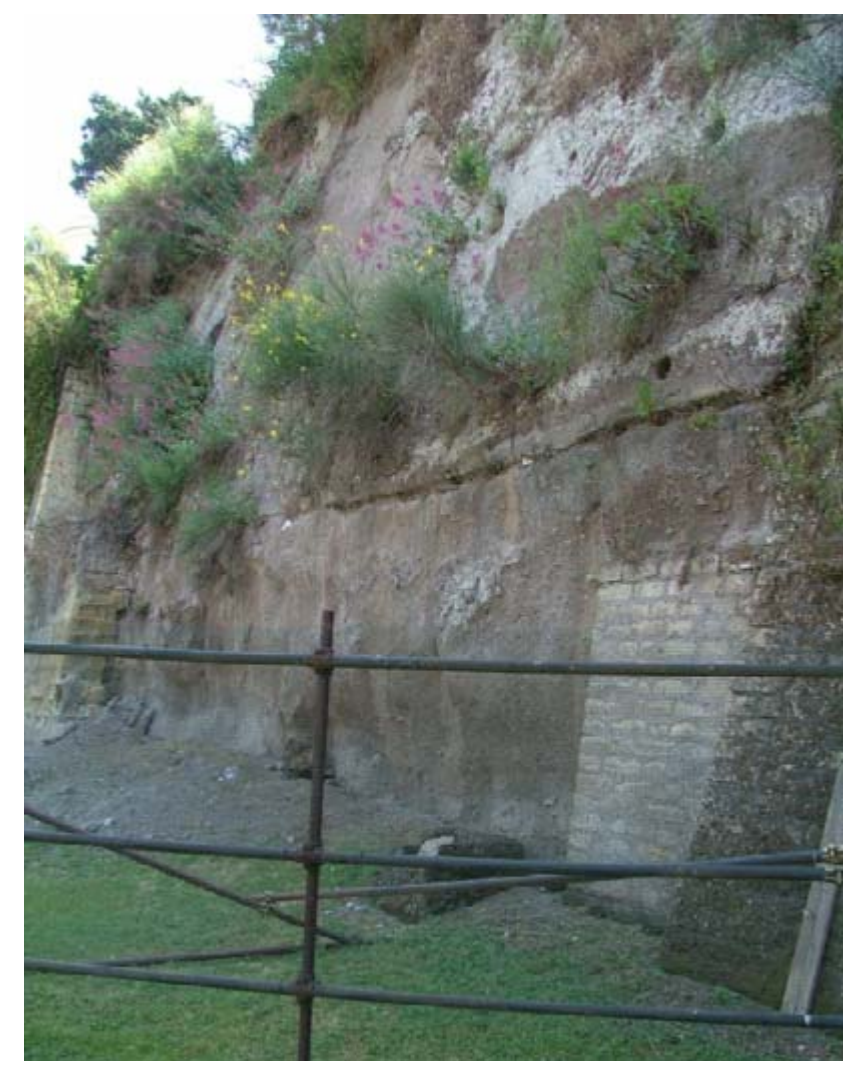

Fig. 32 - The pyroclastic flow deposits, of the 79 AD Pompeii eruption, visible along the eastern excavations walls of the Hercolaneum archaeological site (Photo: R. Cioni).

Facies analysis on PDC deposits reveals both lateral and vertical variations from massive to stratified deposits, which can be related to the combined effects of flow dynamics and local irregularities of the substratum at centimetre or metre scales.

These topographic irregularities enhanced turbulence and allowed rapid transition from non-turbulent to turbulent transport within the flow. Fabric data from these deposits, both from roof tile orientations and anisotropy magnetic susceptibility (AMS) analyses, suggest that the pyroclastic density currents were strongly affected by the presence of buildings. These obstacles probably caused deflection and separation of flows into multiple lobes that moved in different direction.

The figure below illustrates the general stratigraphy of the main cliffs bordering the excavations.

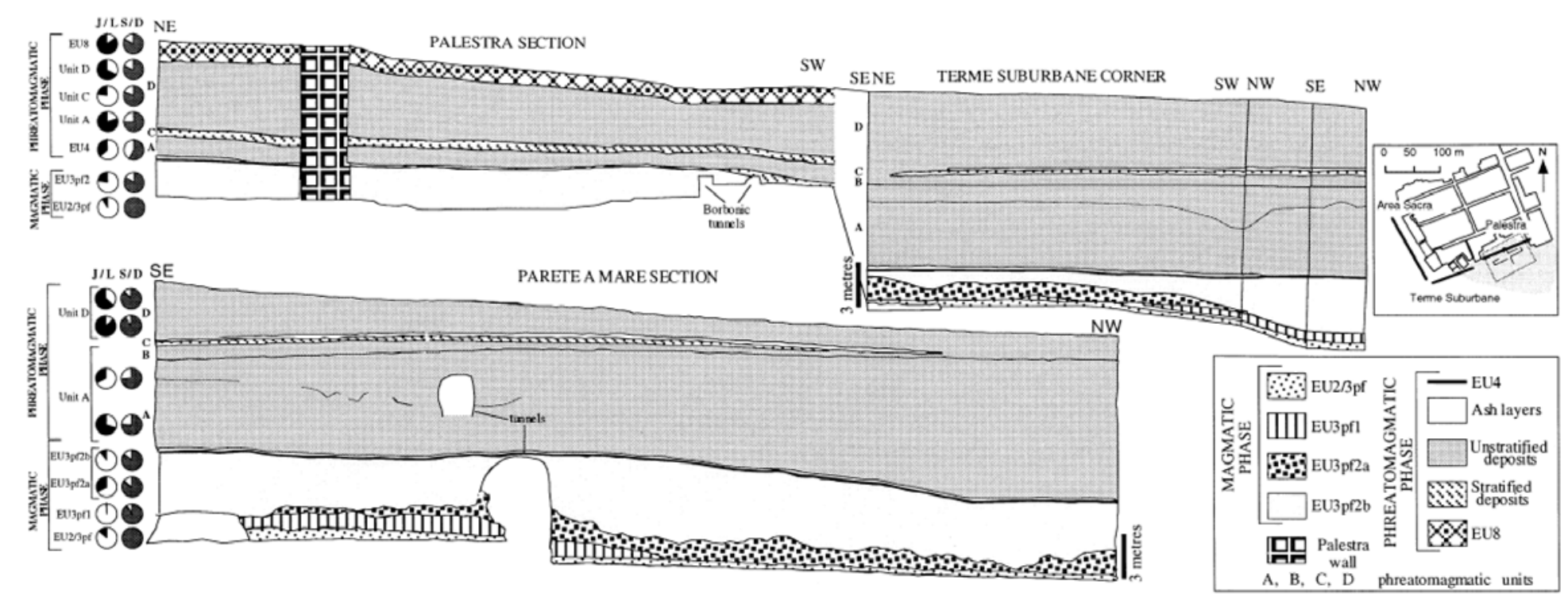

Fig. 33 - Sketch of the stratigraphic relations of the $79 \mathrm{AD}$ pyroclastic flows along the "Palestra", "Terme suburban" corner and "Parete a Mare" inside the archaeological excavations of Herculaneum. Bold lines in the small map at right indicate location of the excavated walls. Ornaments are used to differentiate among flow units. On the left are indicated the component data of the flow units. $\mathrm{J} / \mathrm{L}=$ juvenile/lithic ratio; S/D = lithic from shallow or surficial sources/lithic from deep sited sources (from Gurioli et al., 2002). 


\section{Day 2: Campi Flegrei and Roccamonfina Volcano}

The Campi Flegrei volcanic field (Fig. 28), including Procida and Vivara islands, is a volcanic area formed by small volcanic edifices and several monogenetic volcanoes, in the form of tuff rings, tuff cones and rarely cinder cones and lava domes, cropping out outside, on the borders of, and within a large polygenetic caldera formed by the eruptions of the Campanian ignimbrite and the Neapolitan yellow tuff (e.g., Armienti et al., 1983; Di Girolamo et al., 1984; Rosi \& Sbrana, 1987; Orsi et al., 1992, 1995, 1996, 1999; Cole \& Scarpati, 1993; Di Vito et al., 1999; De Vivo et al., 2001; Ort et al., 1999, 2003).

The oldest volcanic activity is represented by the pre-Campanian ignimbrite deposits, which are found as loose remnants cropping out outside and on the borders of the Campanian ignimbrite caldera and date back to $\sim 80$

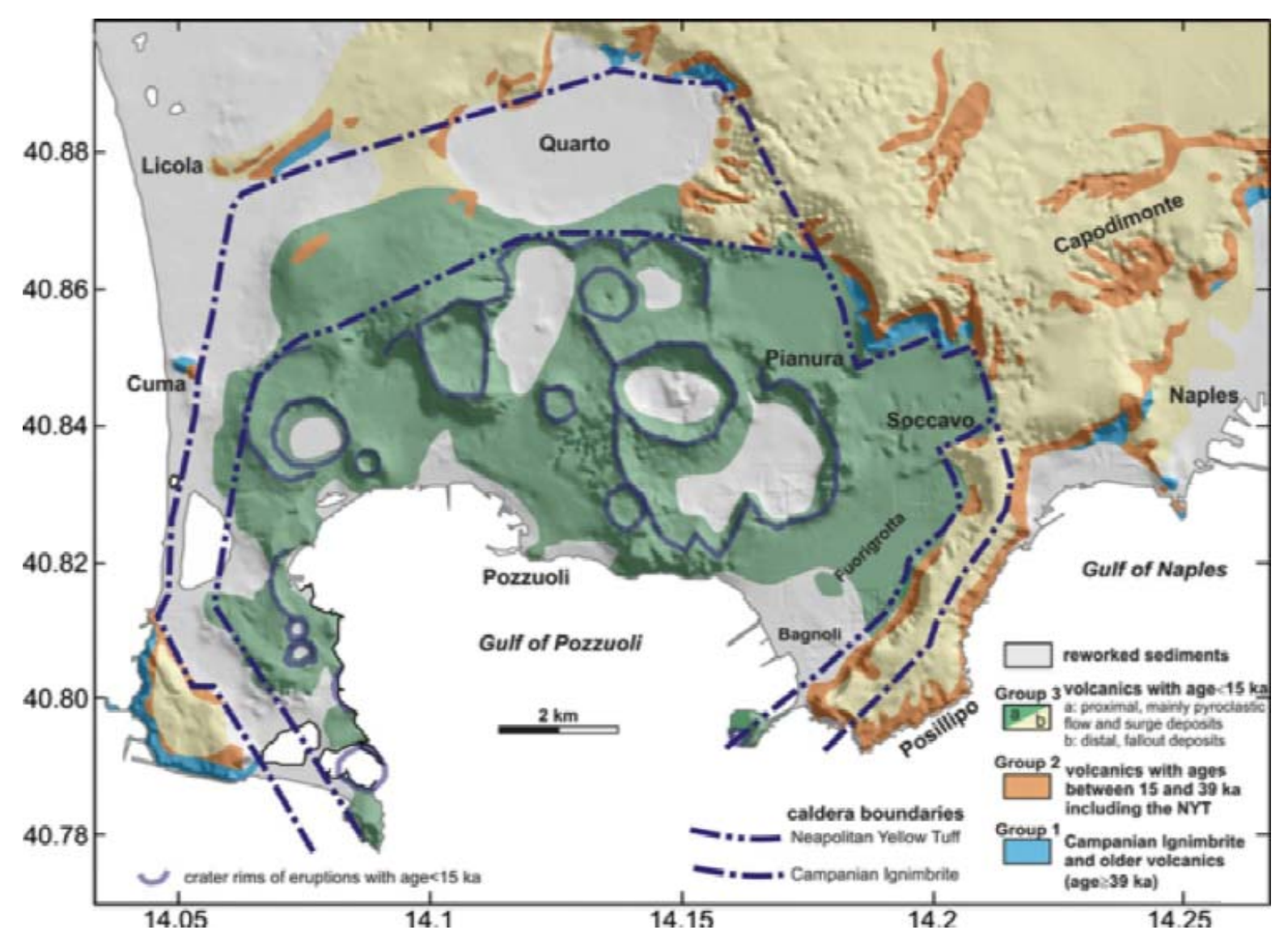

ka (Pappalardo et al., 1999; Scarpati \& Perrotta 2012). Other ignimbritic deposits in the Campanian Plain date back to $\sim 21 \mathrm{ka}$ (De Vivo et al., 2001) and 29 ka (Rolandi et al., 2003). Between 80 and 40 ka there was scattered and monogenetic activity including the cinder cone and associate lava flow of San Martino, the tuff cones of Miliscola and Vitafumo (Monte di Procida), the lava domes of Cuma and Punta Marmolite (north of Quarto plain), the tuff cones of the city of Naples (i.e., Corso Vittorio Emanuele, Monte Echia, and Capodimonte; e.g., Rosi \& Sbrana, 1987; Scarpati \& Perrotta, 2012).

Fig. 34 - Geological sketch map of the Campi Flegrei Volcano (modified after Vitale \& Isaia, 2014). 
The first large volume eruption is represented by the Campanian ignimbrite eruption (Fisher et al., 1993; Rosi et al., 1996: ca. 300 km³ of dense rock equivalent magma - hereafter D.R.E.), whose proximal products are found at the sites of Procida, Monte di Procida, Giugliano, Quarto, Cuma, Camaldoli and San Martino, associated to the related pyroclastic deposits (e.g., Breccia Museo, Piperno, Fig. 35). The Campanian ignimbrite eruption occurred at about $40 \mathrm{ka}$. Indeed, several age data have been published ( $\sim 37 \mathrm{ka}$, Deino et al., 2004; 39 ka, De Vivo et al., 2001; 38 ka, weighted average of 10 samples in Fedele et al., 2008). Intense volcanic activity occurred after the formation of the Campanian ignimbrite caldera, with the formation of pyroclastic deposits from several volcanic centers.

A second large eruption dates back at 15 ka (Deino et al., 2004) with the emplacement of the Neapolitan yellow tuff (Cole \& Scarpati, 1993; Wohletz et al., 1995), which has been estimated to at $40 \mathrm{~km}^{3}$ D.R.E. (Orsi et al., 1992; Scarpati et al., 1993).

The most recent volcanic activity occurred within the Neapolitan yellow tuff caldera and on its borders, dates back to 1538 AD with the eruption of Monte Nuovo (e.g., de Vita et al., 1999; Isaia et al., 2004; D'Oriano et al., 2005). At present, only fumarolic and bradyseismic activity is ongoing.

\section{Compositions of Campi Flegrei products}

The Campi Flegrei and Procida volcanic rocks are predominantly of pyroclastic nature and vary in composition from shoshonitic basalts,

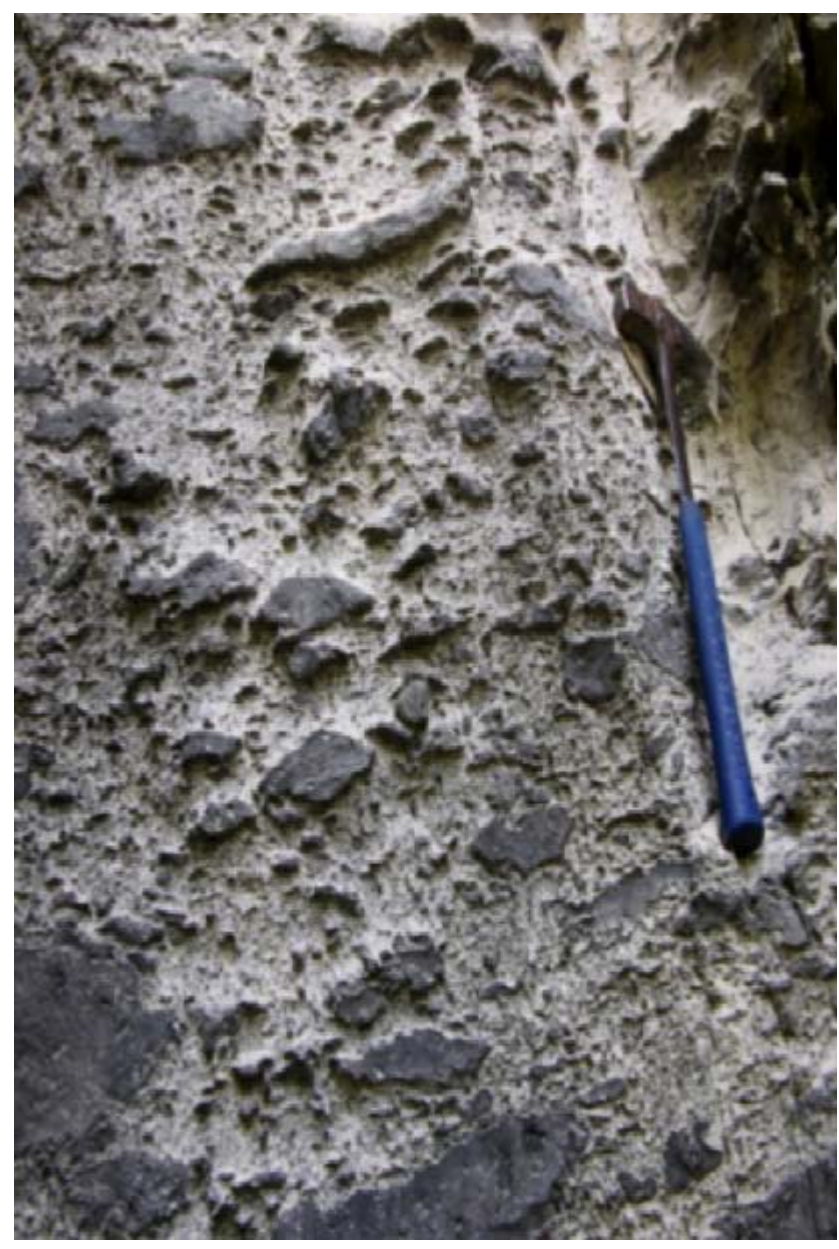

Fig. 35 - Grey welded tuff facies (Piperno) of Campanian ignimbrite (loc. Pianura, Naples; Photo: R. Isaia). through latites, to trachytes and trachyphonolites (Fig. 36), belonging to the shoshonitic series (Fig. 36); some trachyphonolites are weakly peralkaline (e.g., Armienti et al., 1983; Villemant, 1988; Beccaluva et al., 1990; Civetta et al., 1991b; Melluso et al., 1995; Pappalardo et al., 1999a, 2002; D'Antonio et al., 1999b; Conticelli et al., 2004, 2010a; Paone, 2004; Peccerillo, 2005). The most mafic primitive compositions are present at Procida volcano as lava clasts within phreatomagmatic eruptions and scoriae from monogenetic activity (e.g., D'Antonio et al., 1999a; De Astis et al., 2004; Fedele et al., 2006). 
Primitive compositions are rarely found in the mainland within the Campi Flegrei Volcano, where magmas resides for long time within magma chambers being therefore affected by extreme differentiation processes involving fractional crystallisation, magma mixing, and crustal contamination (e.g., Civetta et al., 1991b, 1997; Pappalardo et al., 2002).

The majority of the Campi Flegrei volcanic rocks are trachytes and trachyphonolites (Fig. 36), including the chemically zoned Campanian ignimbrite and Neapolitan yellow tuff products (e.g., Scarpati et al., 1993; D'Antonio et al., 1999a, Fedele et al., 2008). Evidence of interaction between mafic and evolved magmas is clearly seen in most pyroclastic eruptions (Fedele et al., 2008), and is more frequent in the latest stage of activity ( $<15 \mathrm{ka})$, where less evolved compositions are frequently found (Fig. 37).

The mafic rocks have phenocryst assemblages mainly of Fo-rich olivine, hosting chromian-spinel inclusions, Mg-rich clinopyroxene, and Ca-rich plagioclase. Latites have more Na-rich plagioclase, with clinopyroxene, phlogopite, magnetite phenocrysts and microlites, whereas trachytes have the typical assemblage $\mathrm{K}$ - to Na-rich sanidine, Na-plagioclase, Fe-rich clinopyroxene, Fe-rich amphibole and several accessoriy phases, with additional groundmass or microphenocryst of sodalite \pm nepheline. Mixed phenocryst assemblages are found in lava domes and pyroclastic rocks (e.g., Fedele et al., 2008).

Incompatible, primordial mantle normalised, trace element patterns of the mafic volcanic rocks from Campi Flegrei and Procida have mild enrichment with smooth fractionation of large ion lithophile with respect to high field strength elements (Fig. 36). Ta and Nb troughs are smooth compared to other Roman

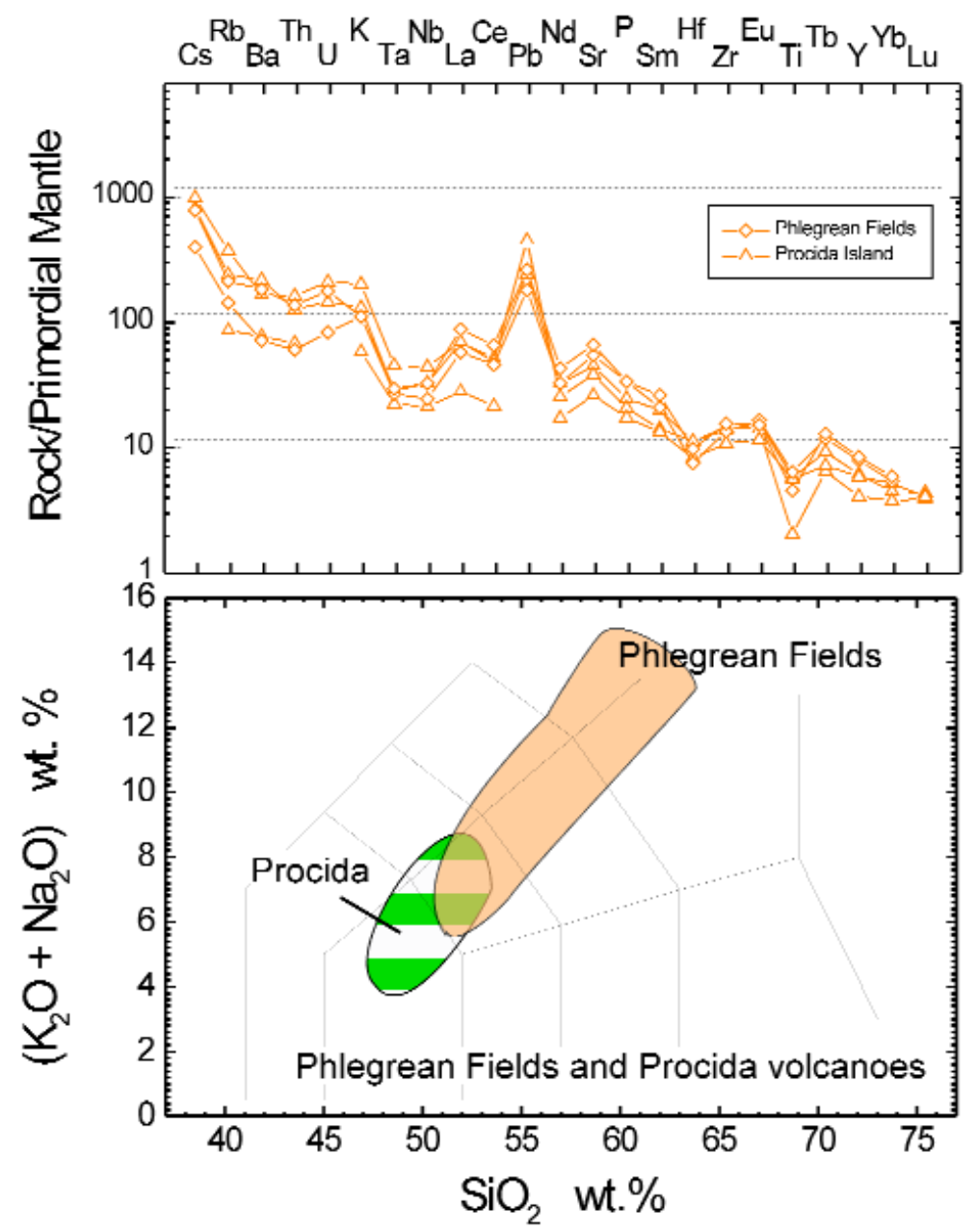

Fig. 36 - Classification and geochemical characteristics of the Campi Flegrei and Procida volcanic rocks. A) Total Alkali-Silica (TAS) classification diagram (Le Maitre, 2002). B) Incompatible trace element patterns for mafic volcanic rocks normalised to the primordial mantle values of Sun \& McDonough (1989). Data from Pappalardo et al. (1999, 2002), D'Antonio et al. (1999b), Fedele et al. (2006, 2008, 2016), Avanzinelli et al. (2008). 


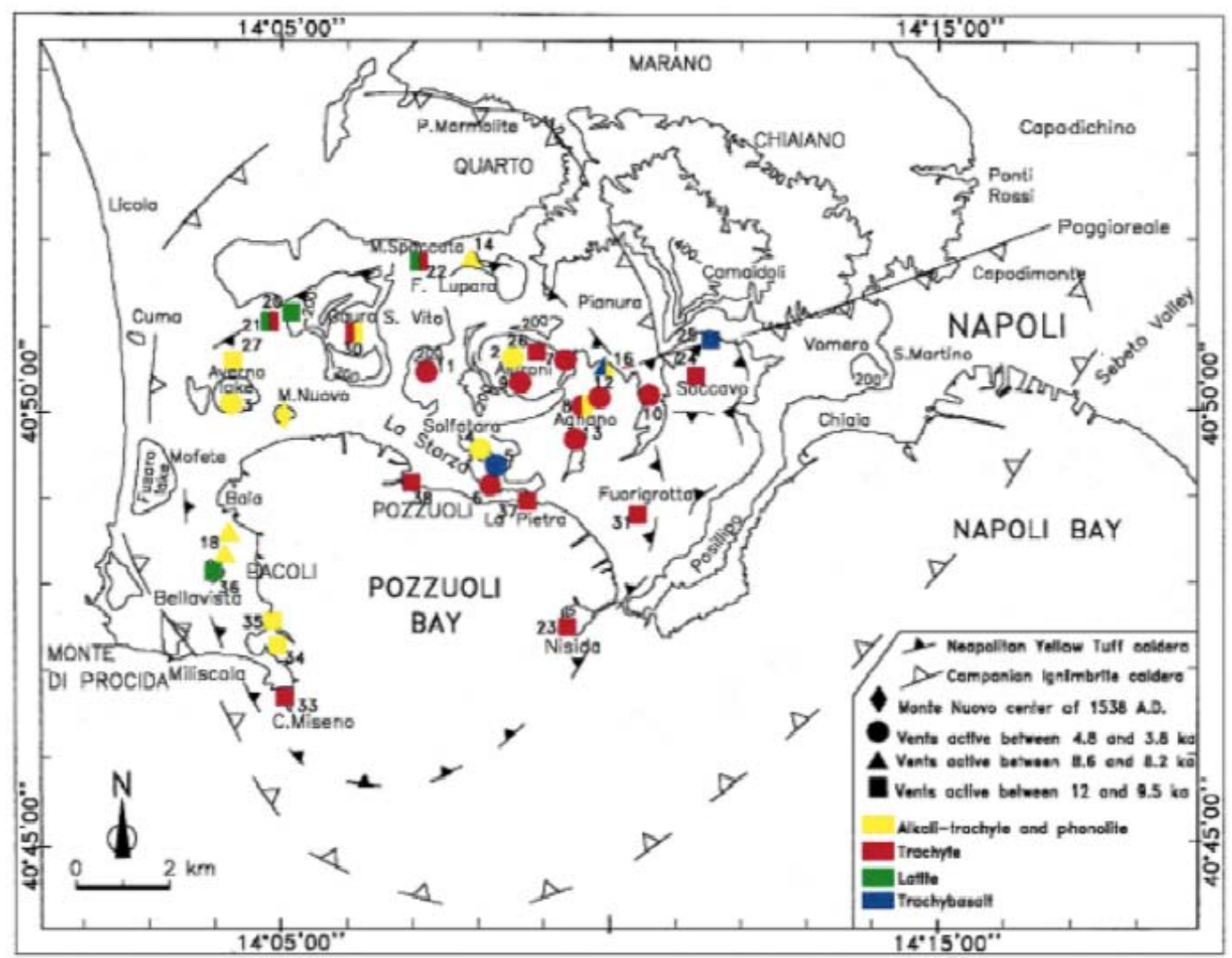

Fig. 37 - Map showing the relationships between location of vents active during the three epochs of Campi Flegrei activity in the past $15 \mathrm{ka}$ and the compositions of the erupted magma (from

D'Antonio et al., 1999b).

and crudely stratified upper portion. Pyroclastic density-currents, which controlled the Campanian ignimbrite emplacement over an area of about $30,000 \mathrm{~km}^{2}$ (Fig. 37), show homogeneous sedimentological characteristics in medial and distal areas (10-80 km from the vent)(Fisher et al., 1993).

More than $300 \mathrm{~km}^{3}$ of magma and volcanic ash were emitted during this eruption, with tephra extending eastward into Russia (Fig. 32; Giaccio et al., 2008; Costa et al., 2012; Smith et al., 2016). The Campanian ignimbrite shows a limited compositional variability of pyroclastics from trachytic to trachyphonolitic (eg. Melluso et al., 1995; Civetta et al., 1997; Signorelli et al., 1999; Pappalardo et al., 2002; Marianelli et al., 2006; Giaccio et al., 2008). In

volcanoes. The Ba trough is absent, whereas the $\mathrm{Hf}$ trough is more pronounced (Fig. 36). It is important to note, as for the Neapolitan district, the relatively low $U$ and Th abundances with respect to the other Italian ultrapotassic and related igneous rocks, with also peculiar U/Th ratios (Avanzinelli et al., 2008).

The record of paroxysmal activity and magma chambers

At Campi Flegrei volcano two large eruptions occurred, which gave rise to the Campanian ignimbrite and the Neapolitan yellow tuffs, respectively.

The Campanian ignimbrite sequence includes a basal Plinian fallout deposit overlain by pyroclasticdensity currents deposits, which in proximal areas are intercalated by densely welded ignimbrite (Piperno; Fig. 35) and lithic-rich breccia units ("Museum Breccia"). The basal Plinian deposit (Rosi et al., 1999), dispersed towards the East, consists of a well-sorted and reversely-graded lower portion, followed by a well- to poorly-sorted DOI: 10.3301/GFT.2017.01 


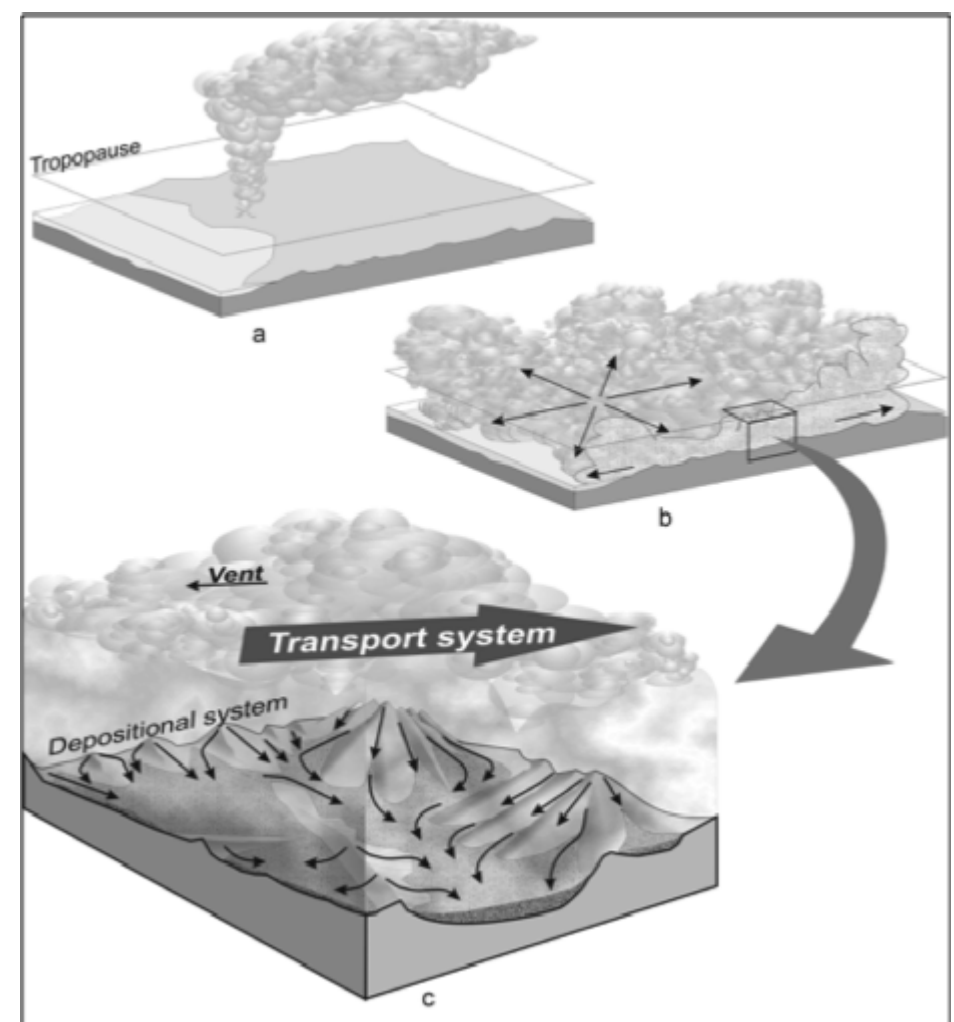

Fig. 38 - Phases of the Campanian ignimbrite eruption ( $a, b)$ and model for pyroclastic density currents transportation and depositional system (c). a) Plinian sustained eruption column; b) expanding pyroclastic density currents; c) block diagram showing the movement of the pyroclastic density currents over the palaeotopography. Large arrow indicates the flow direction of the dilute transport regime current, smaller arrows indicate the gravity flows (from Fedele et al., 2003).

particular, Civetta et al. (1997) investigated the geochemistry of pyroclastic density currents (PDC) deposits and described three main compositional groups, not systematically arranged according to the stratigraphy of the deposits, but distinguished according to their areal distribution and distance from the vent. In terms of major element compositions, the difference among these groups is mainly in their $\mathrm{K}_{2} \mathrm{O} / \mathrm{Na}_{2} \mathrm{O}$ ratio and the relative abundance of $\mathrm{CaO}, \mathrm{Fe}_{2} \mathrm{O}_{3}, \mathrm{MgO}$ and $\mathrm{Cl}$. The study of the interstitial glasses and melt inclusions of the Campanian ignimbrite fallout and breccia deposits (Signorelli et al., 1999; Marianelli et al., 2006) indicates a similar compositional variability. Analyses of the breccia museum unit, outcropping in the western sector of the Campi Flegrei, revealed a stratigraphic arrangement of this compositional variability parallel to an upward increase of the less evolved products (Melluso et al., 1995), a connection that was later recognised by Pappalardo et al. (2002) in another proximal sequence of the Campanian ignimbrite at Ponti Rossi, East of the Campi Flegrei. As a whole, the variability in the Campanian ignimbrite rock composition indicates that this eruption was fed by a trachytic magma chamber which included two chemically different magmatic layers: a more evolved upper magma layer, and a less evolved lower layer (e.g. Civetta et al., 1997).

The magma chamber that fed the Campanian ignimbrite eruption was located between 6 and $8 \mathrm{~km}$ depth (Marianelli et al., 2006), and its partial depletion led to the formation of the Campi Flegrei caldera (Fig. 38). The caldera margins have been the subject of various interpretations in recent literature (e.g., Rosi \& Sbrana 1987; Orsi et al., 1996, 2004; Perrotta et al., 2006; Acocella et al., 2008) that differ mainly in the definition of the eastern sector of the collapsed area, with particular reference to the inclusion or exclusion of the city of Naples in the area affected by the collapse. Some authors (Lirer et al., 1987; Rolandi et al., 2003) exclude the formation of a caldera in relation to 


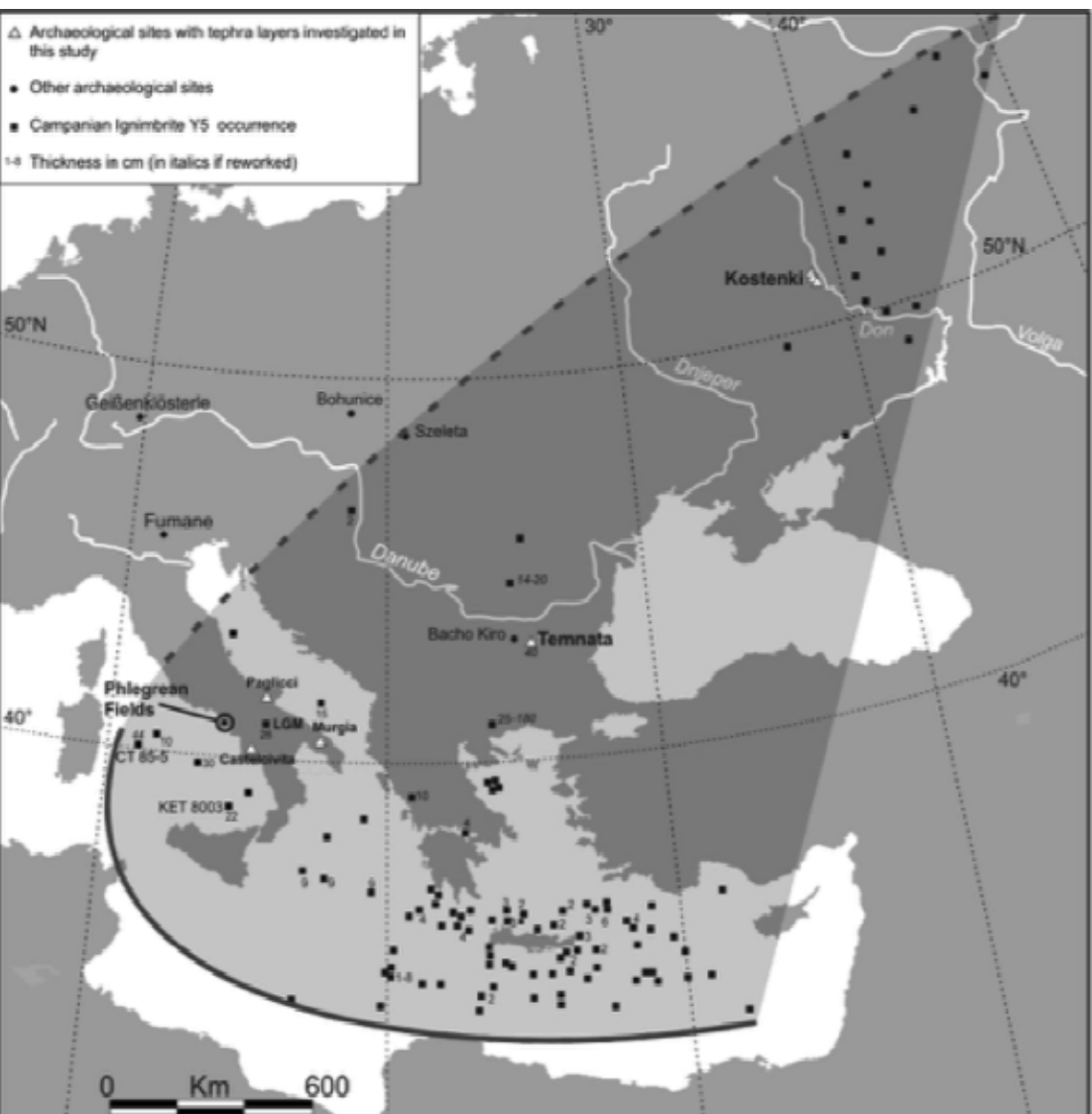

Fig. 39 - Distribution of the Campanian ignimbrite distal tephra layer (above) and of its intermediate-proximal deposits (below) with superimposed isopachs of the Plinian fallout unit (details and complete references in Fedele et al., 2003, and Giaccio et al., 2008). The sites of the analysed tephra samples are shown. Inset: generalised columnar section of the Campanian ignimbrite in proximal areas, with its distinctive units and related $40 \mathrm{Ar} / 39 \mathrm{Ar}$ ages as reported by De Vivo et al. (2001)(from Giaccio et al., 2008).

the Campanian ignimbrite eruption, suggesting that the caldera formation occurred at around $15 \mathrm{ka}$, associated with the eruption of the Neapolitan yellow tuff (Deino et al., 2004).

The Neapolitan yellow tuff eruption was the last large eruptive event in the history of Campi Flegrei Volcano. The eruption was a phreatoplinian to phreatomagmatic event that erupted about 40 km³ (D.R.E.) of magma (Orsi et al., 1992; Scarpati et al., 1993). The volcanic products of this eruption cover an area of about $1,000 \mathrm{~km}^{2}$. The main flow units of the Neapolitan yellow tuff are generally zeolitised (Fig. 40), and they were exploited, with some
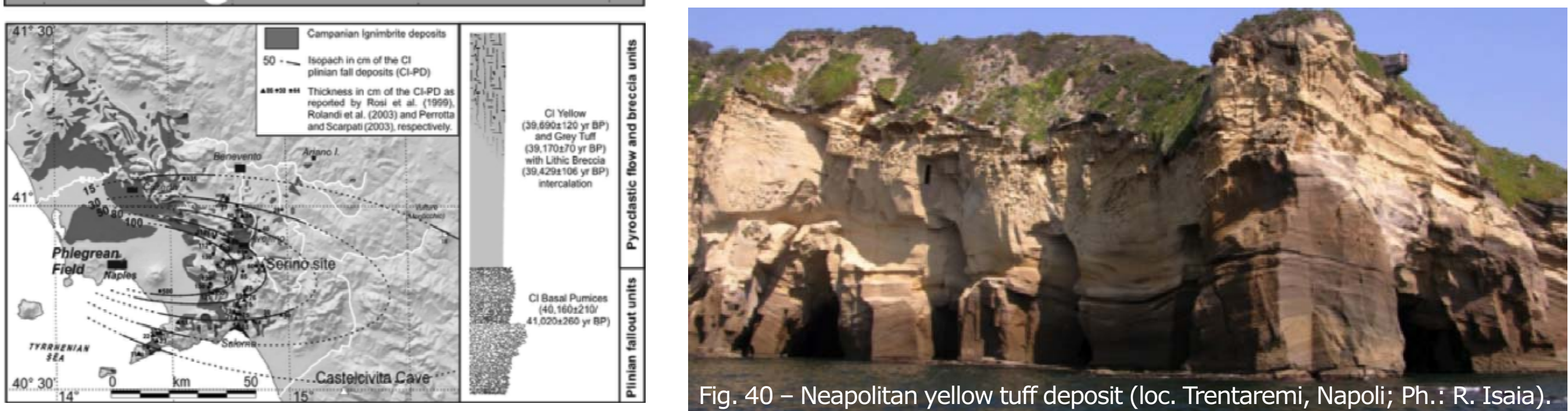
quarries still in activity, as building stones for most of the buildings of the city of Naples. The Neapolitan yellow tuff sequence was divided into a lower member (LM) and an upper member (UM), on the basis of textural characteristics, dispersal of tephra, and occurrence of an angular unconformity.

The lower member is a pyroclastic flow emplaced by the largest known trachytic phreato-Plinian eruption. Its thickness varies from $11 \mathrm{~m}$ in the most proximal exposures, to $85 \mathrm{~cm}$ at Sant'Angelo in Formis, at the foot of the Apennine chain, $35 \mathrm{~km}$ from the vent area.

The characteristics of the upper member are those typical of a phreatomagmatic eruption. Its thickness varies from about $100 \mathrm{~m}$ in the Quarto Plain, to about $7 \mathrm{~m}$ in the Caserta Plain, some $40 \mathrm{~km}$ north of the vent.

The composition of the Neapolitan yellow tuff juvenile products varies from latite to alkali trachyte (Orsi et al., 1995; Pappalardo et al., 2002). They are crystals-poor ( $<3 \%$ by volume), with a population made of sanidine, plagioclase, clinopyroxene, biotite, and magnetite, in order of decreasing abundance. Accessory apatite is rarely found. Mineral chemistry indicates the chemical disequilibrium with whole rock as also suggested by the occurrence of labradoritic plagioclase in trachyte (Civetta et al., 1997). The magma chamber was composed of three discrete layers: an upper alkali trachyte, an intermediate trachyte and a lower alkali trachyte to latite magmas separated by compositional gaps (Orsi et al., 1995). The Neapolitan yellow tuff eruption led to a further collapse of Campi Flegrei caldera (Orsi et al., 1992; Scarpati et al., 1993), whose margins are exposed only along the eastern edge of the Bagnoli plain, along the Coroglio cliff (Fig. 34). With this relatively large eruption, the Campanian ignimbrite caldera was probably reactivated with further collapse occurring in the center (Orsi et al., 2004).

The post-caldera activity

Following the eruption of the Neapolitan yellow tuff, volcanic activity renewed within the caldera through tens of eruption centres (Fig. 41) that gave rise to 70 volcanic eruptions, at

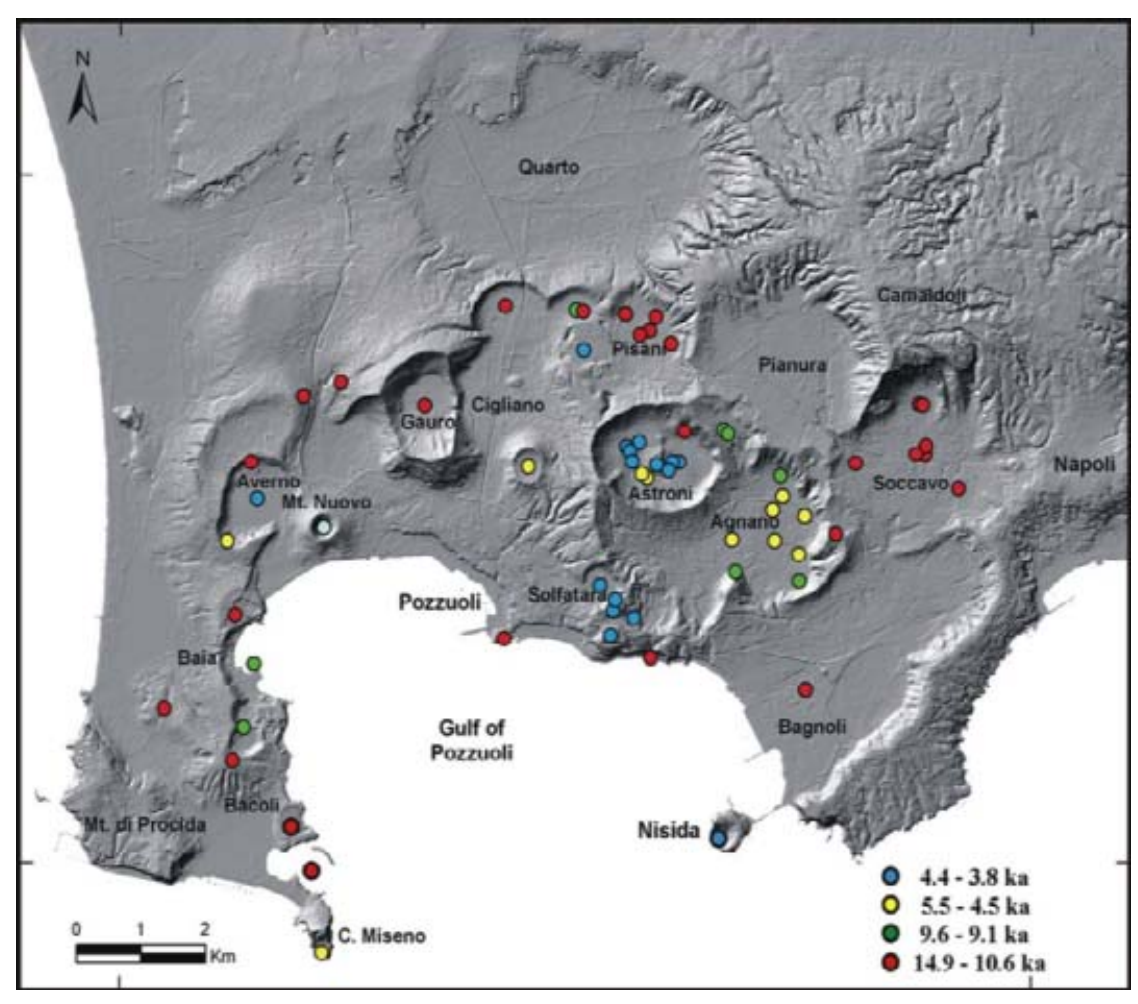

Fig. 41 - Location of the eruptive vents of the last 15 ka within the Campi Flegrei caldera (from Isaia \& Smith, 2013). 
least. The location of vents has changed over time (Fig. 41), most recently being concentrated in the central-eastern part of the caldera, with respect to the western sector (Isaia et al., 2009; Vilardo et al., 2010). Simultaneous eruptions in the two different sectors of the caldera have also occurred: i.e. from the Solfatara and Averno volcanoes (Isaia et al., 2009).

The volcanism was mainly concentrated in discrete periods alternating with periods of quiescence of variable length (Fig. 42; Di Vito et al., 1999; Isaia et al., 2009). The eruption of Monte Nuovo in 1538 AD represents the last eruption of the post-caldera activity.

The post-caldera activity of the Campi Flegrei Volcano was mainly characterised by mild explosive eruptions with subordinate effusive events. During the last 15,000 years there have been only two high-magnitude eruptions characterised by Plinian phases: the "Agnano Pomici-Principali" and the "Agnano-Monte Spina" (Di Vito et al., 1999; De Vita et al., 1999). The eruptive events of medium and low magnitude were dominant.

During this phase the variability of the energy involved is indicated by the different areal distribution of deposits and by the different volumes of magma emitted involved. Indeed, only few eruptions of the post-Neapolitan yellow tuff (post-NYT) discharged in the atmosphere a volume of magma $>1 \mathrm{~km}^{3}$ (Orsi et al., 2004; Di Renzo et al., 2011). Evaluation of magma volume involved in the Campi Flegrei post-caldera activity is generally underestimated due to the lack of proximal deposits for many of the recognised eruptions. Indeed the lack of proximal deposits does not allow the tephrostratigraphical correlation with layers found in many palaeoenvironmental archives across the Mediterranean and thus the exact reconstruction of the volume of the material emitted (Smith et al., 2011).

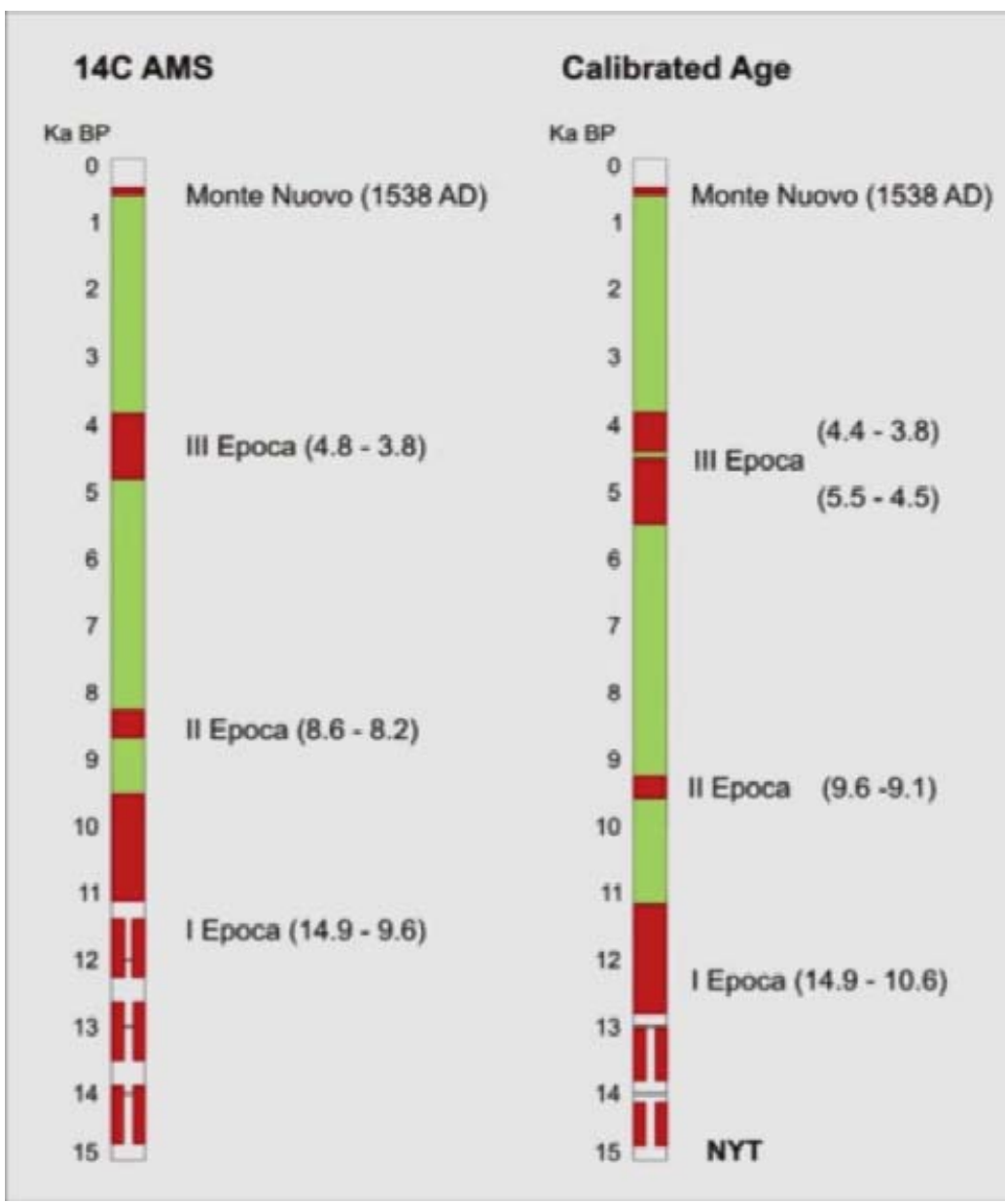

Fig. 42 - Chronostratigraphyc scheme of the volcanism younger than $15 \mathrm{ka}$ at the Campi Flegrei caldera (from Isaia \& Smith, 2013). 
Indeed, the largest post-caldera ( $>15 \mathrm{ka}$ ) eruption that involved a D.R.E. volume of magma $>>0.1 \mathrm{~km}^{3} \mathrm{dispersed}$ ash over wide areas. Deposits of these eruptions (Fig. 43) indicate that they had phases that were either subplinian to plinian with eruption columns that extended well into the stratosphere. The plinian and subplinan

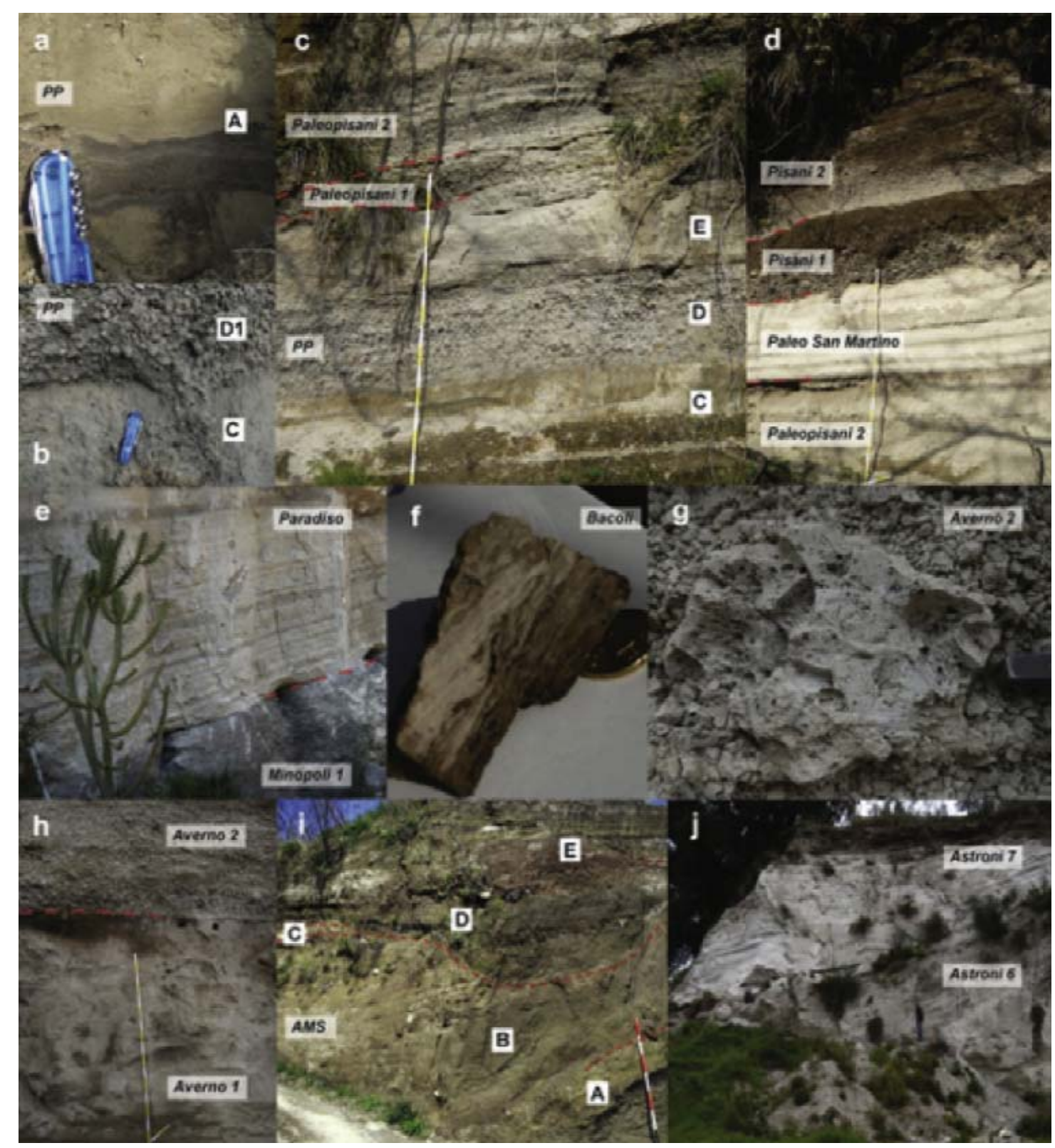
column were generally widespread toward EastNortheast, while low height columns laid down fallout deposits in variable directions.

Fig. 43 - Typical proximal deposits of the post-NYT eruptions. (a) and (d) outcrop near the NNW caldera margin. Eruption deposits (italics in transparent boxes) and units are labelled. (a) PP unit A with coarse violet ash at the base and finer ash above. (b) PP phreatomagmatic (C) and magmatic (D1) fallout units. (c) The upper PP units. E comprises PDC deposits followed by Paleopisani 1, a $25 \mathrm{~cm}$ pumice lapilli unit, and Paleopisani 2, which comprises alternating beds of fine ash and lapilli (staff with $10 \mathrm{~cm}$ increments for scale). (d) Paleo San Martino fine phreatomagmatic ash with acceretionary lapilli is overlain by the coarser pumice units of Pisani 1 and Pisani 2. (e) Coarse clast supported deposits that comprise the Minopoli 1 tuff cone are overlain by Paradiso, poorly sorted phreatomagmatic fallout unit. (f) Mingled Bacoli clast in the deposits (coin for scale). (g) Averno 2 vesicular pumice blocks (part of hammer for scale); and (h) the finer phreatomagmatic Averno 1 deposits below the magmatic pumice lapilli and block unit of Averno 2. (i) AMS with units labelled. An unconformity overlies unit C, a phreatomagmatic ash with accretionary lapilli, which often is completely eroded. (j) Astroni 6 pyroclastics with person for scale. The pyroclastic currents that dominate the photo are underlain and overlain by fallout units (from Smith et al., 2011). 


\section{Ground deformation and bradyseism}

The Campi Flegrei caldera was characterised by ground deformation, which resulted in a total uplift of more than $100 \mathrm{~m}$ in its central part during the last 10,500 years. The main epoch of volcanism was preceded by resurgence episodes resulting in meters to tens of meters of uplift (Di Vito et al., 1999; Isaia et al., 2009) in response to magma movements at depth. Several decades before the Monte Nuovo eruption, ground uplift attained several meters (e.g., Dvorak \& Gasparini 1991; Morhange et al., 2006; Guidoboni \& Ciuccarelli, 2011).

Following the 1538 eruption, Campi Flegrei entered a phase of subsidence that continued until 1950 (Del Gaudio et al., 2010). Recently, slow ground movement (bradyseism) occurred in this area, with two major bradyseismic crises (1970-72 and 1982-84, Fig. 44) accompanied by hundreds of earthquakes and $3.5 \mathrm{~m}$ of ground uplift (Barberi et al., 1984), forcing the partial evacuation of the town of Pozzuoli. Different episodes of 'micro-uplift' with maximum displacements of few tens of $\mathrm{cm}$ occurred in the last 30 years and are currently underway. Many geophysical and geochemical data on the dynamics of the unrest episodes have been produced and discussed (e.g., Orsi et al., 1999; Battaglia et al., 2006; Bodnar et al., 2007; Vilardo et al., 2010; Chiodini et al., 2012). The migration of either magmatic or hydrothermal fluids as trigger of the unrest is still debated as is the structural pattern that favours the degassing and deformation of the caldera. Widespread fumarolic and hydrothermal activity, the historic eruption of Monte Nuovo, and the recent bradyseismic crises, are the main volcanic phenomena indicating that magmatic system of the Campi Flegrei remains active.

In an active volcanic system

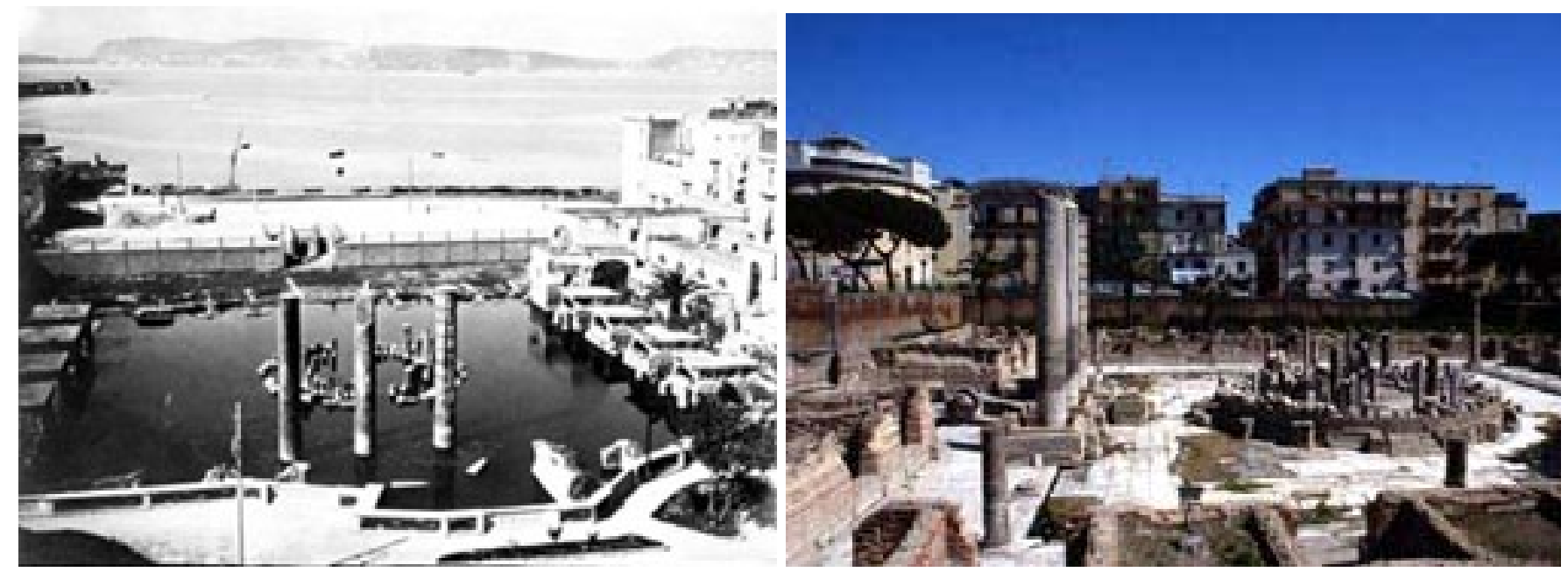

Fig. 44 - The Serapeum invaded by seawater (left) completely dry (right), earlier and later of the 1980-1982 crisis, respectively (http://www.ov.ingv.it/ov/it/campiflegrei/storia-eruttiva.html). 
characterised by high frequency explosive activity alternating with long rest periods, variable vent opening area and unrest crises without eruptions, a volcanic hazard assessment and zoning for the expected hazards are fundamental for volcanic risk mitigation strategies. The Department of Civil Defence released an emergency plan draft that included a vent opening area map and a risk map for the area exposed to the highest probability of pyroclastic currents, indicated as the Red Zone. The Red Zone of Campi Flegrei includes ten neighbourhoods of Naples (e.g., Bagnoli, Fuorigrotta, Pianura, and Soccavo), the town of Pozzuoli, the entire towns of Bacoli, Monte di Procida, and Quarto and part of the Giugliano and Marano Municipalities. About 500,000 people living in the Red Zone will have to be evacuated when the warning level is reached.

\section{The Stops of the morning of the $2^{\text {nd }}$ day}

The morning of the second day will be spent in the Campi Flegrei to observe the caldera and the post-caldera activity and bradyseism. The Stops allow us to observe some of the main volcanic structures giving the opportunity to illustrate and discuss the history of the Campi Flegrei Volcano, the ground deformation dynamics, and to focus the possible future scenario and the risk related to a resumption of the eruptive activity. The map of figure 45 shows the location of the field trip Stops, containing also, as stop 3, the Pozzuoli harbour and Serapeo site where this Field Trip around the volcanoes of Central Italy started.

Fig. 45 - Maps showing the location of the three Stops at Campi Flegrei Volcano and the main roads around and within the caldera.

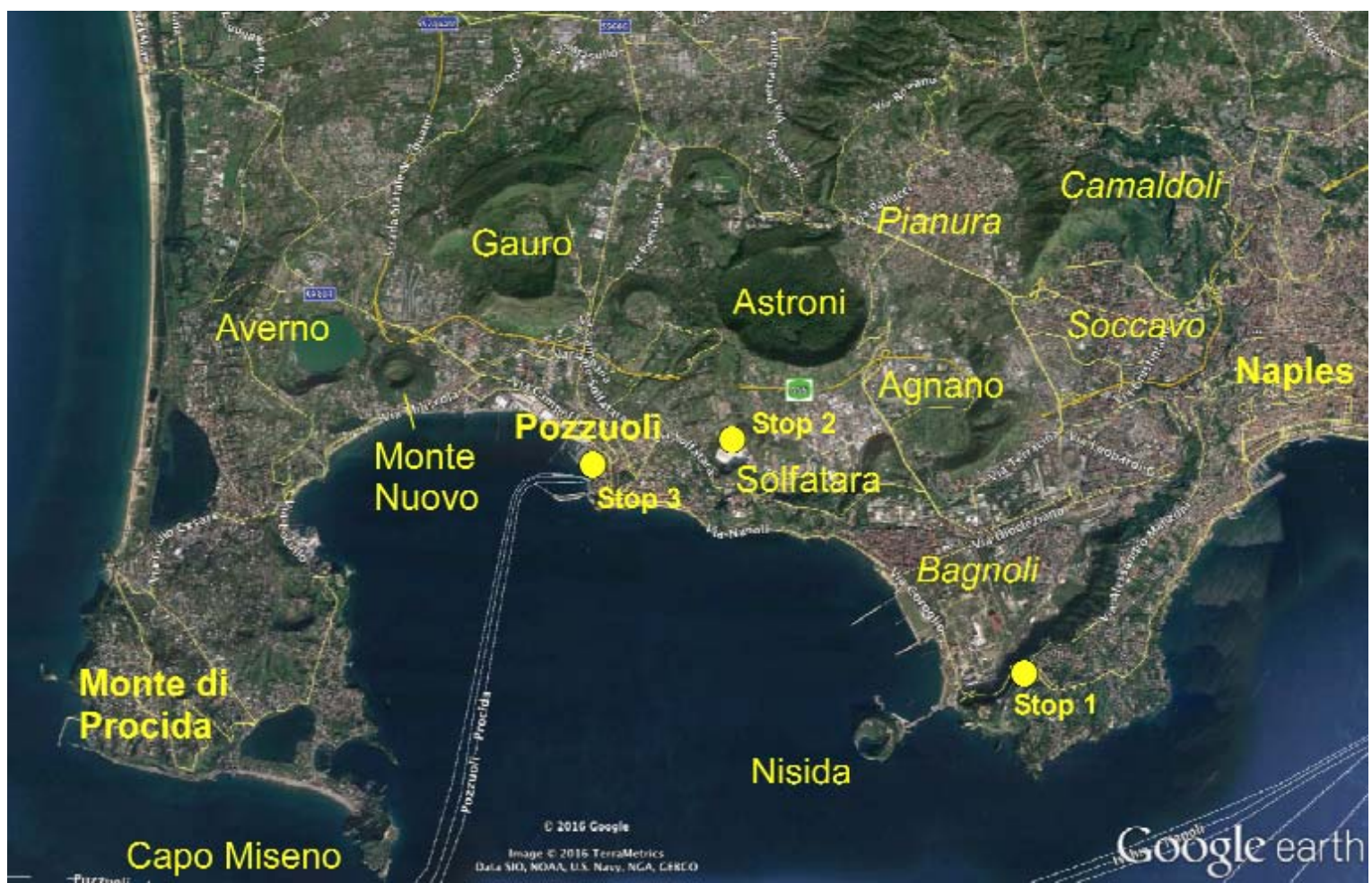


You will drive up to the Posillipo hill, a volcanic high that divide downtown Naples from Fuorigrotta neighborhood. You will stop in front of the main gate of the Posillipo garden $\left(40^{\circ} 48^{\prime} 37^{\prime \prime} \mathrm{N}-14^{\circ} 11^{\prime} 01^{\prime \prime} \mathrm{E}\right)$. From this site is possible to have a general view of the Campi Flegrei caldera (Figs 45 and 46). Towards the North there is the Camaldoli hill, whose slopes are constituted of thick successions of pyroclastic deposits that date at about $50 \mathrm{ka}$. The high-angle slope, which forms the top of the Camaldoli hill, represents the edge of the Campi Flegrei caldera and along the cliff a thick sequence of the Campanian ignimbrite is exposed.

The Campanian ignimbrite eruption formed the Campi Flegrei caldera and definitely changed the landscape of a large part

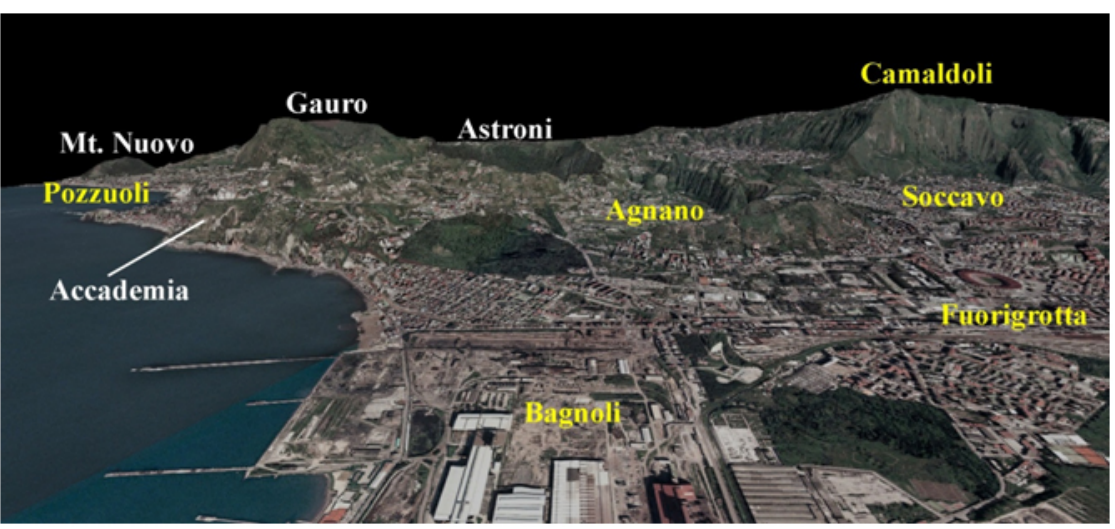

Fig. 46 - Overview of the Campi Flegrei caldera seen from the Posillipo Hill (courtesy of G. Vilardo "Laboratorio di Geomatica e Cartografia", Osservatorio Vesuviano, INGV). of the Campania Plain, which became "Campania Felix" for the ancient Romans. In the upper part of the Camaldoli scarp (Fig. 46) are the yellowish tuff deposits laid down by the second largest eruption of the volcano: the Neapolitan yellow tuff (NYT). Note that the Camaldoli hill is the highest point of the Neapolitan-Phlegraean area (434 m a.s.I.).

Looking toward the inner part of the caldera the typical landscape of a large volcanic field characterized by several monogenetic volcanic centres ranging from cinder cone (e.g. Monte Nuovo) to tuff cones (e.g., Gauro), tuff rings (e.g., Astroni, Solfatara) and lava domes (e.g., Accademia, Olibano) can be noted. These volcanic edifices, in many cases, are only partially preserved due to subsequent explosive activity that partially destroyed previous volcanic edifice and erosion process mainly by sea-water, which in some cases have formed marine terraces (e.g. La Starza, Pozzuoli) or coastal plains as the Bagnoli area just below the lookout point. It is worth noting that the Stop 1 stands along the only visible scarp related to the collapse occurred during the Neapolitan yellow tuff eruption.

Looking towards the west, one can have a view of the central volcanic vents of the caldera with the hill bordering the Agnano plain and the Astroni tuff ring. The former results from a volcano-tectonic collapse 
during the Agnano-Monte Spina eruption. The Astroni tuff ring (Fig. 47) is a well preserved elliptical edifice, with axes of about 2 and $1 \mathrm{~km}$, formed during the most recent epoch of activity of the Campi Flegrei caldera (Di Vito et al., 1999, Isaia et al., 2009). Isaia et al. (2004), on the basis of a stratigraphic study, have defined for the Astroni tuff-ring seven depositional units, delimited by either thin paleosols or erosional unconformities. The eruption vents, although confined in the present crater, migrated from NW to SE. The volcano grew at the north-western edge of the Agnano-Monte Spina volcano-tectonic collapse through the seven eruptions followed each other at very short time intervals. The sequence of very close eruptions makes the Astroni tuff-ring peculiar in the recent history of the caldera. Therefore, the definition of its history is important in order to understand one of the past phenomenons of the caldera, relevant to forecast its future behaviour. Behind the Astroni and Gauro monogenetic volcanoes, looking toward the south-west are the Averno-Capo Miseno alignment of tuff cones and tuff rings, which marks the western margin of the Neapolitan yellow tuff caldera. Beside the town of Pozzuoli is the Monte Nuovo cinder cone formed during the only hystorical eruption of the caldera.

The general view of the Campi Flegrei caldera structure highlights how large and densely populated districts of Naples are developed entirely inside the caldera and contemporaneously to have an idea about the work that has to be done to mitigate and manage the volcanic risk in this area. At the same time the overall appearance of the caldera allows us to make an immediate comparison in terms of structure and morphology with the other active Somma-Vesuvius Volcano.

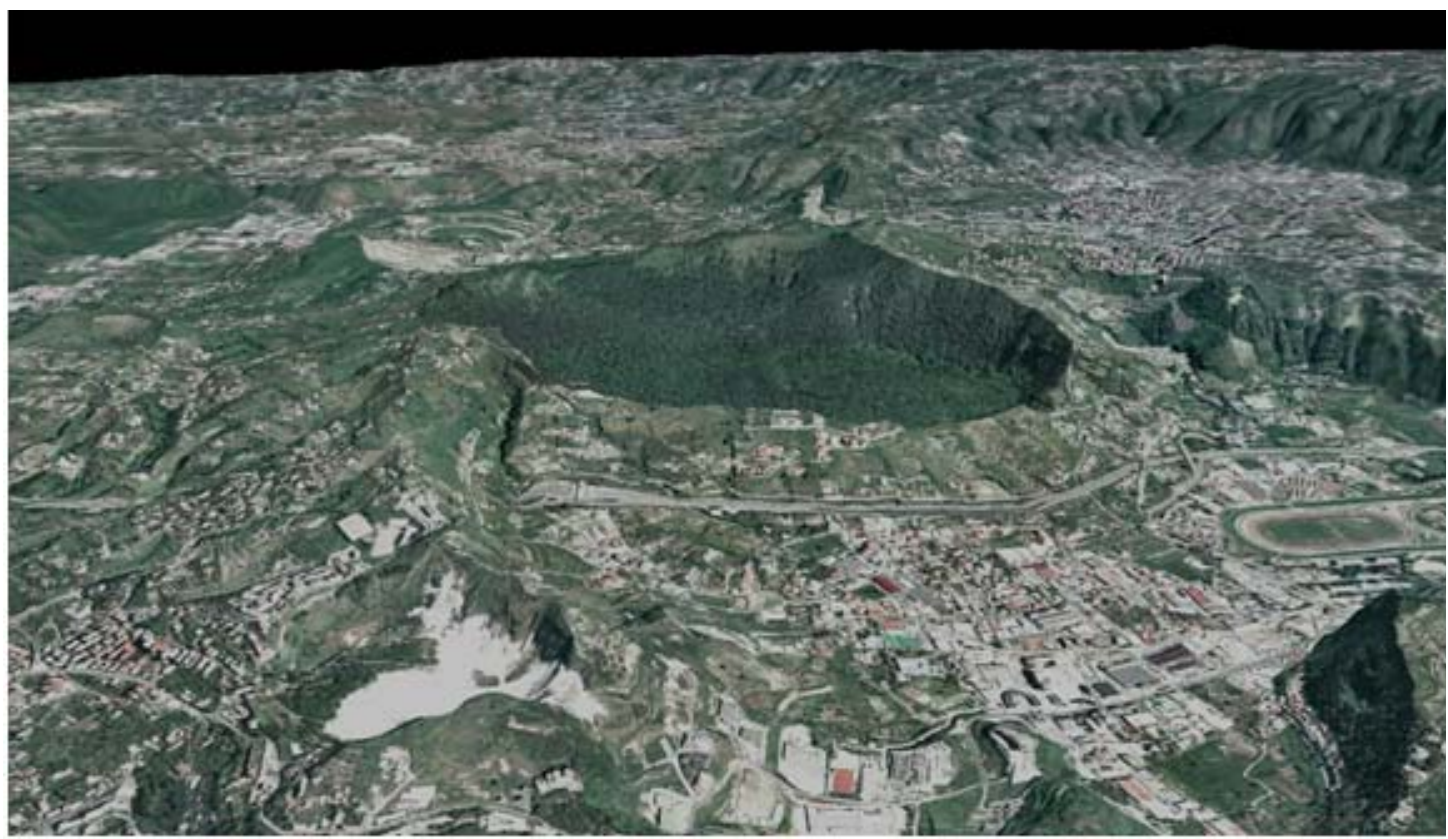

Fig. 47 - Air view of the Astroni tuff-ring from the south (courtesy of G. Vilardo "Laboratorio di Geomatica e Cartografia", Osservatorio Vesuviano, INGV). 
STOP 2.2: the volcanic and hydrothermal activity in the volcano Solfatara

The "volcano Solfatara" (Fig. 48), located in the central sector of the Campi Flegrei caldera $\left(40^{\circ} 49^{\prime} 40^{\prime \prime} \mathrm{N}-14^{\circ} 08^{\prime} 08^{\prime \prime} \mathrm{E}\right)$, is one of the most recent volcanic edifices with an age of about 4,200 years BP. The Solfatara volcano, about $2 \mathrm{~km}$ EastNortheast of Pozzuoli, is characterised by a subrectangular $(0.5 \times 0.6 \mathrm{~km})$ crater, shaped by prevailing NW-SE and SW-NE trending faults (Isaia et al., 2015).

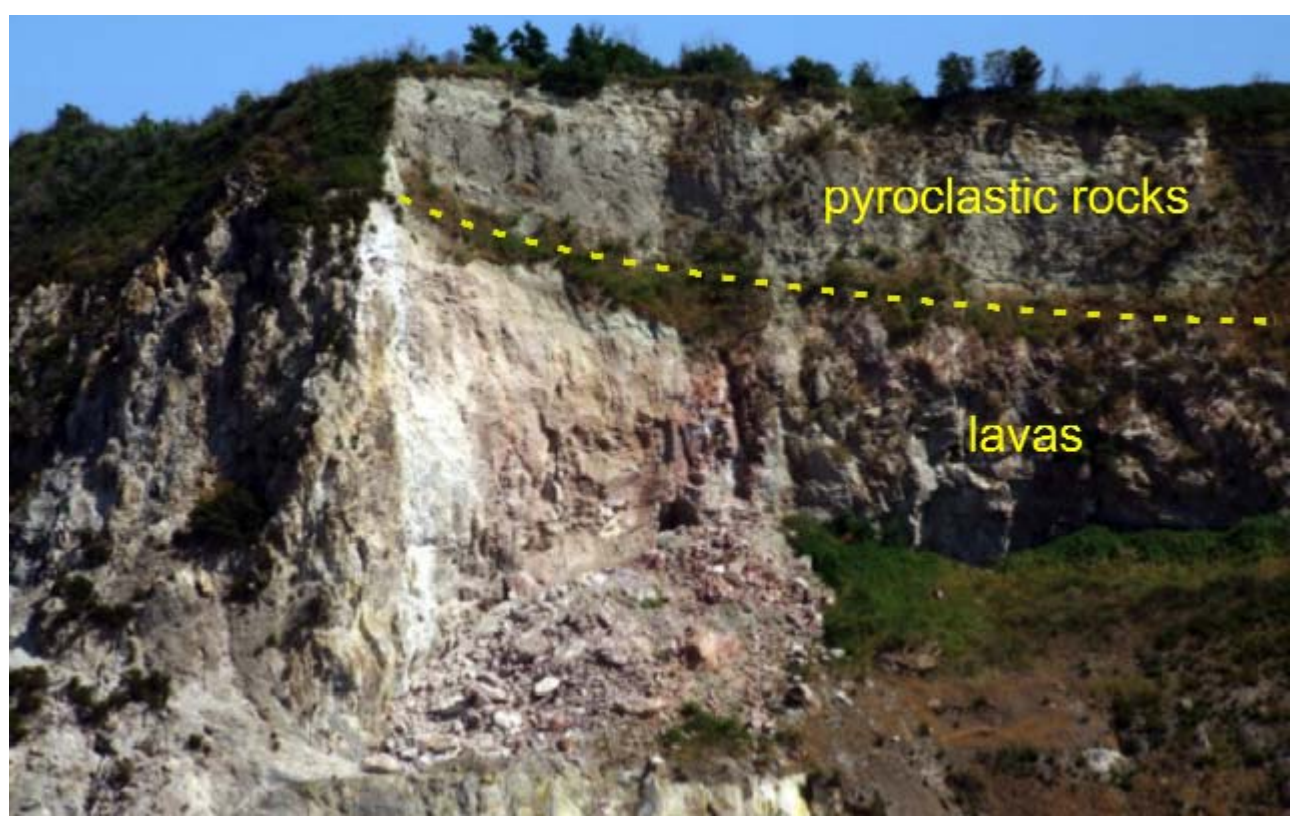

Fig. 49 - Sequence of volcanic rocks exposed along the eastern inner wall of the crater of Solfatara crater within the Phlegrean Field caldera (Photo: R. Isaia).

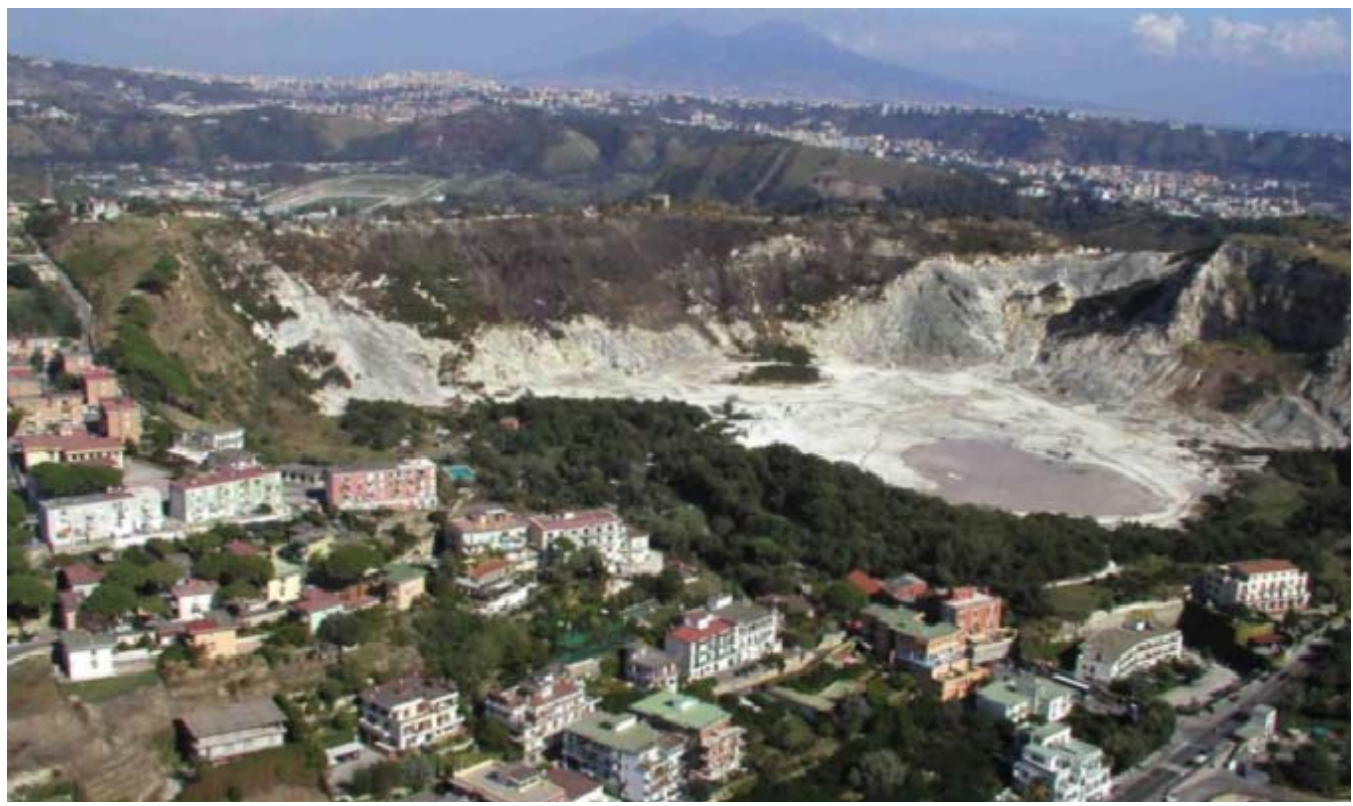

Fig. 48 - Air view of the Solfatara tuff ring.

The Solfatara tuff maar volcano after the emplacement of the Monte Olibano exogenous lava dome, successively covered by the Olibano phreatic eruption and the Accademia exogenous lava dome emplacement. Olibano pyroclastic flows have a limited areal dispersion and overlain the Olibano lavas (Fig. 49). The eruptive activity of Solfatara was mainly characterised by phreatic and phreato-magmatic explosions and minor magmatic phases, with generation of pisolitic surges and minor ash fallout deposits. The latter consisting mainly of massive, coarse to fine, whitish ash beds in the lower part and 
an alternating fine-to-coarse ash layers (Fig. 50), with lenses rich in large lava blocks in the proximal areas. A thin fallout deposit dispersed to the NE up to around seven $\mathrm{km}$ from the eruptive center, was associated with Solfatara crater.

The crater of the Solfatara has been the site of an intense hydrothermal activity (Fig. 51) since Greek times. It is the most impressive manifestation of the present hydrothermal activity of the caldera, which includes both focused vents, with a maximum temperature of about $160^{\circ} \mathrm{C}$ (Bocca Grande fumarole), and large areas of hot steaming ground. The average molar composition of the fluids is $\mathrm{H}_{2} \mathrm{O}$ about 82 wt. $\%, \mathrm{CO}_{2}=17.5$ wt. $\%, \mathrm{H}_{2} \mathrm{~S}=$ 0.13 wt. $\%$ with minor amounts of $\mathrm{N}_{2}, \mathrm{H}_{2}, \mathrm{CH}_{4}$ and $\mathrm{CO}$.

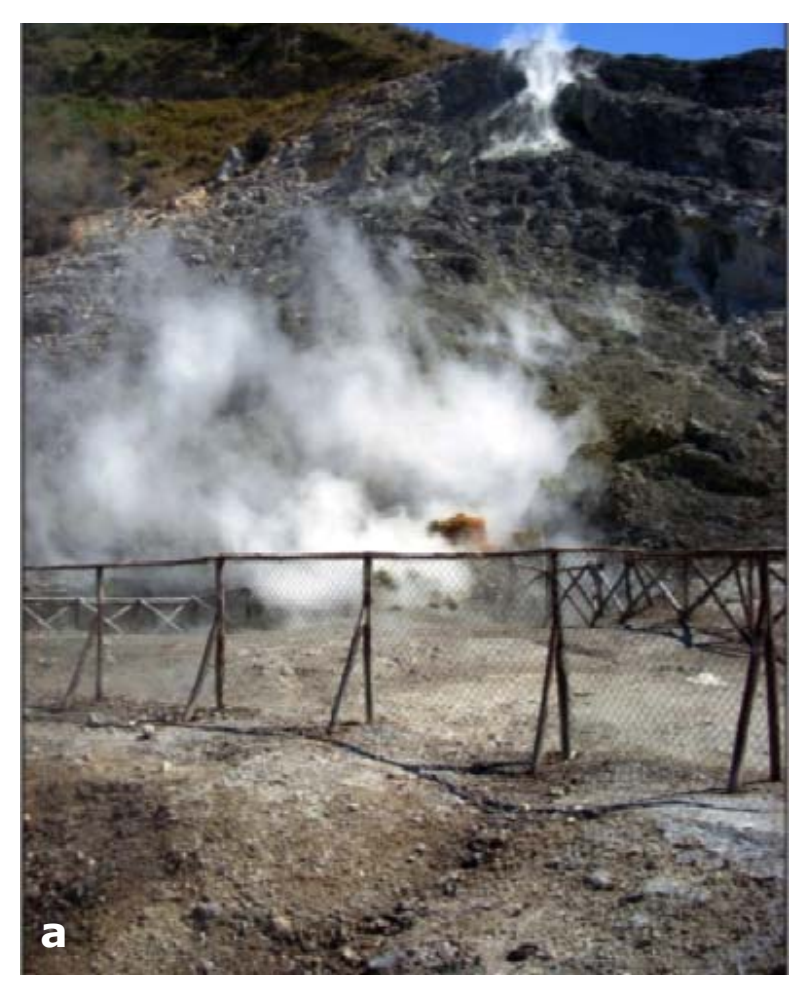

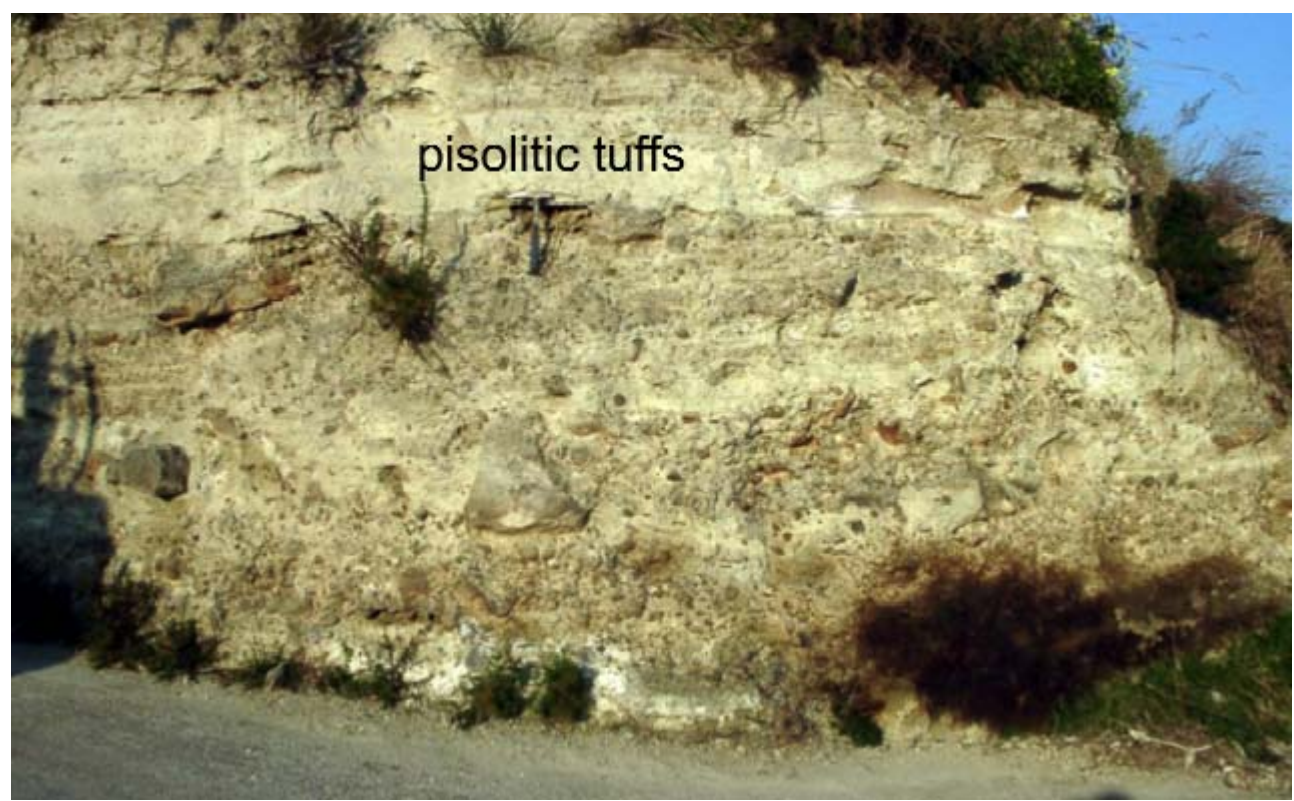

Fig. 50 - Sequence of alternating deposits of pisolitic surge and ash fall along the northern inner wall of the of the Solfatara crater within the Campi Flegrei caldera (Photo: R. Isaia).
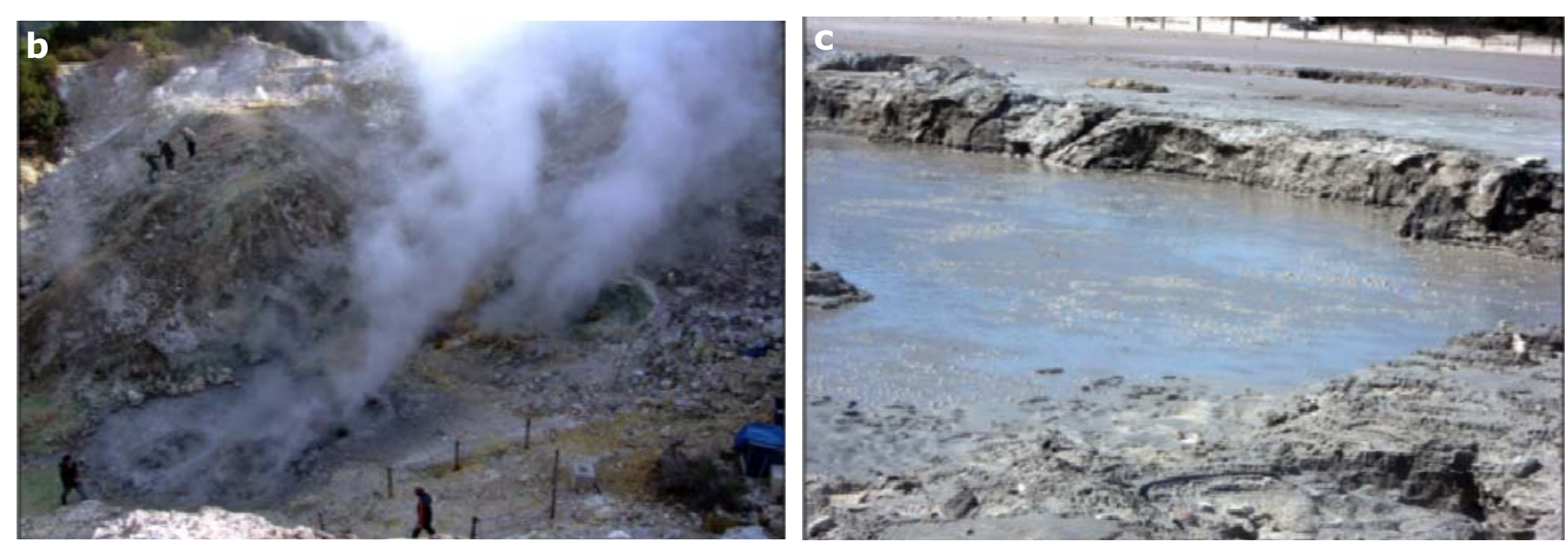

Fig. 51 - (a) and (b) Fumarolic and hydrothermal vents in the crater of Solfatara; (c) Pisciarelli fumarole (Photos: R. Isaia). 
The isotopic compositions of $\mathrm{H}_{2} \mathrm{O}, \mathrm{CO}_{2}$ and He suggest the involvement of magmatic gases in the feeding system of the fumaroles (Chiodini et al., 1997). The original magmatic gases have been condensed by an aquifer system as suggested by the absence of the soluble acid gases $\mathrm{SO}_{2}, \mathrm{HCl}$ and $\mathrm{HF}$, typical of the high-T volcanic gas emissions. Boiling of this aquifer(s) generates the Solfatara fumaroles. At present the Solfatara is the main object of the geochemical surveillance of the caldera. In particular both the chemical compositions of the fumarolic fluids and $\mathrm{CO}_{2}$ fluxes from the soil of the crater are monitored. The Solfatara volcano is an example of low energy eruption dynamics. It allows us to understand the influence of tectonic structures in generating different volcanic morphologies. Also the geochemical activity and its geochemical monitoring is clearly shown at Solfatara.

\section{STOP 2.3: the Serapeum and the bradyseism}

The ground deformation is a particular sign that reveals the breath of a volcanic active area. Historical documentary sources report that slow movement of the ground in the area of Campi Flegrei is a well-known phenomenon since Roman times. In the Baia area several Roman age buildings are now under the sea due to continuous subsidence of central-western sector of the caldera. In addition, there are documentary sources reporting a consistent uplift of the ground in the area of the ancient Roman harbour of Averno before the 1538 AD eruption, which brought to the build-up of the Monte Nuovo cinder cone. The uplift started at least 30 years before the eruption and constantly increased with the approach of the eruptive event. The marine regression that occurred arose disputes on the attribution of ownership of new lands emerged from the sea, until the eruption started and covered all new lands.

The most famous example that helps to reconstruct the slow ground deformation (bradyseism) in the Campi Flegrei Volcano is the so called Serapeum (i.e., Temple of Serapis) of Pozzuoli $\left(40^{\circ} 49^{\prime} 35^{\prime \prime} \mathrm{N}-14^{\circ} 07^{\prime} 15^{\prime \prime} \mathrm{E}\right)$. The Serapeo, located few tens of meters inland at Pozzuoli, was first supposed to be a temple devoted to the Egyptian god Serapis, from which the name. Only at the beginning of the last century it was recognized as a marketplace. Excavation of the monument began in 1750, by order of Charles of Bourbon the king of Naples, in an area called "the vineyard of the three columns" because three marble columns were coming out of the ground. After excavation, the columns showed lythodomes holes up to $7 \mathrm{~m}$ above the floor of the monument, testifying the maximum subsidence of the area (Fig. 44).

The first scholar to analytically set the problem of how the columns of the Temple of Serapis were perforated by lithodomes was the abbot Scipione Breislak in the eighteen century. Indeed, he believed that such 
phenomenon had occurred either as the result of the sea level variations, or to changes in the level of the ground (Giudicepietro \& D'Auria, 2013).

Since then the Temple of Serapis became the object of several study and measurements of the ground uplift and lowering in the Campi Flegrei. Intense comparative measurements of benchmarks located into the Temple of Serapis and along the Pozzuoli promenade, nearby the "Rione Terra" area starting on 1905 allow the definition of the continuous experimental curve of the ground deformation of the Pozzuoli area through the entire twentieth century (Fig. 52), through the bradyseismic crisis of 1980-82 AD (Del Gaudio et al., 2010). In figure 52 the variation of the elevation in meters with respect the sea level from 1905 AD (green line) of both Serapeum floor and topographic benchmark, respectively, is reported. It is noteworthy the strong correlation existing between the values of the benchmark (red stars) and the values of the Serapeum floor (blue dot) that argue for a an elevation related with a general slow uplift of the entire Pozzuoli area rather than an eustatic variation.

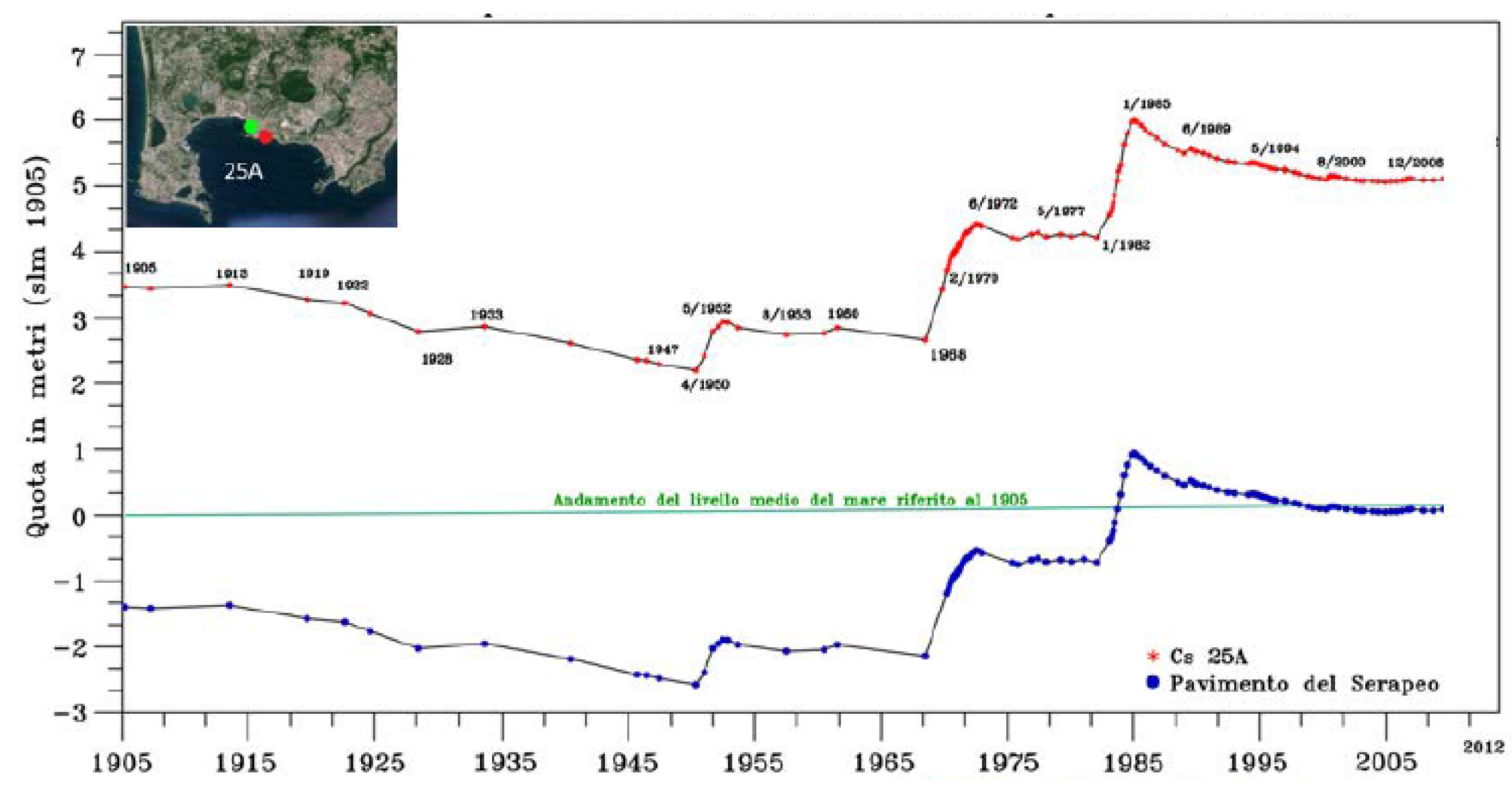

Fig. 52 - Elevation changes of the floor level in Pozzuoli measure at the "Serapeum" and at the benchmark BM 25A, sited along the promenade near the "Rione Terra". On horizontal axis years from 1905 to 2012 $A D$ are reported. Green and red dots in the inset are the position of the Serapeum and of the benchmarck, respectively (from Giudicepietro \& D'Auria, 2013). 


\section{Roman Province: the Latian Districts}

The Latian volcanic districts of the Roman Magmatic Province (Avanzinelli et al., 2009) occupy the central portion of the Italian peninsula from nothern Campania to Southern Tuscany, and they are from South to North (Fig. 53): the Roccamonfina Volcano, the Middle Latin Valley volcanic field, the Colli Albani Volcano, the Sabatini volcanic field, the Vico Volcano and the Vulsini volcanic field, the latter made up by the coalescence of three large volcanic edifices (i.e., Bolsena, Montefiascone and Latera volcanoes). The Latian volcanic centres have been active coevally during the Pleistocene and presently most of them are quiescent rather than extinct. The Latian districts of the Roman Magmatic Province overlay the older volcanic rocks belonging to the Tuscan Magmatic Province (Fig. 53). The volcanism of the Latian Districts began at about $760 \mathrm{ka}$ and continued to the

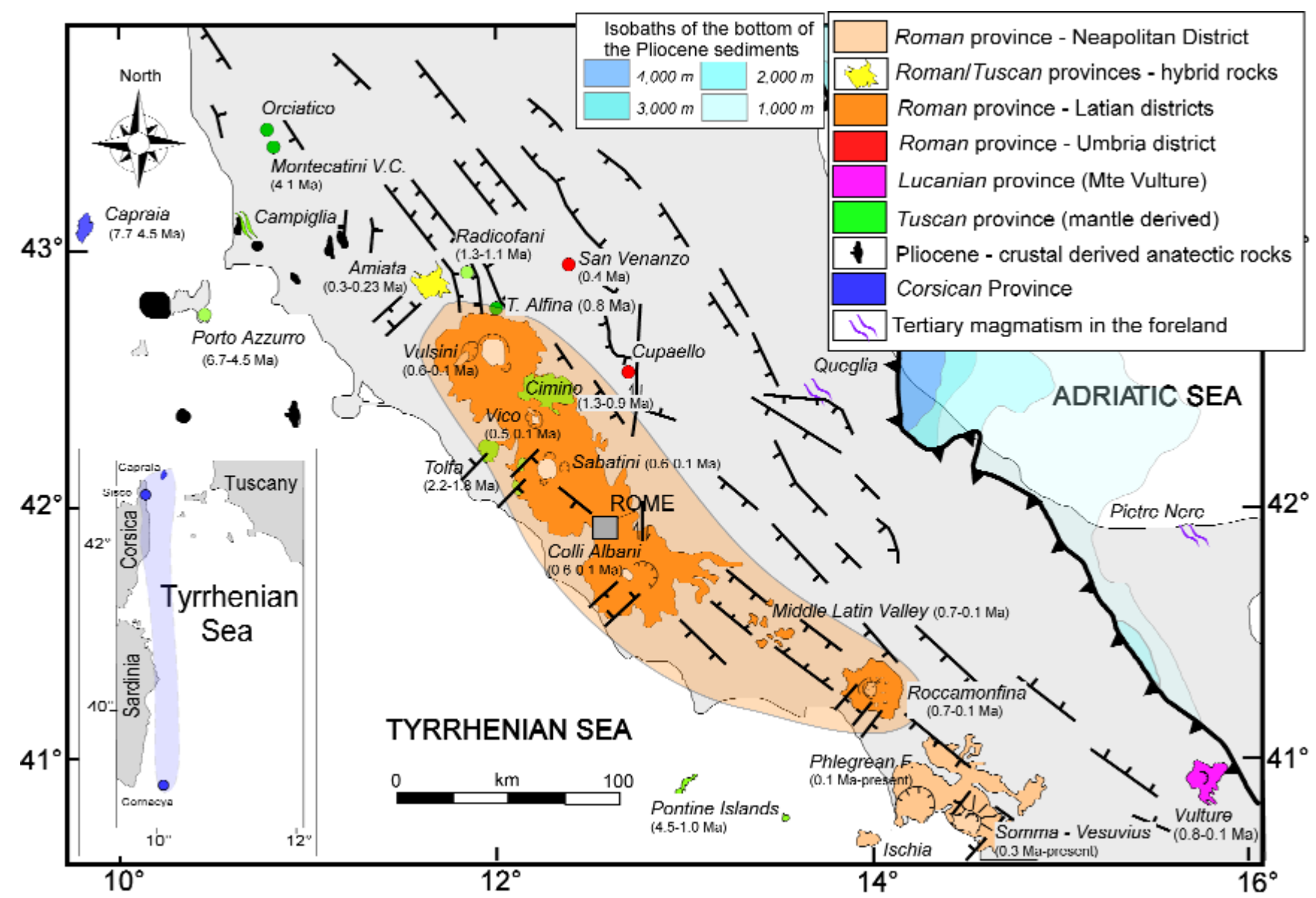
end of the Pleistocene (Florindo et al., 2007; Conticelli et al., 2010a), with a maximum production of volcanic rocks between 400 and $200 \mathrm{ka}$. The volcanic activity of the Latian Districts partially overlaps with that of the volcanoes of the Neapolitan district (Fig. 9; Conticelli et al., 2010a).

Fig. 53 - Distribution of Plio-Pleistocene ultrapotassic igneous rocks and associated shoshonites and calc-alkaline rocks from Eastern Tyrrhenian Sea and Italian Peninsula (Corsican, Tuscan, Roman and Lucanian Magmatic Provinces). Neapolitan, Latian and Umbrian districts of the Roman Magmatic Province are also distinguished. Redrawn after Conticelli et al. (2010a, 2013, 2015a). 
On the basis of petrographic data the Latian volcanic districts are mainly made up of leucite-bearing ultrapotassic magmas, in some cases preceded by hybrid Tuscan-Roman magmas, as in the cases of early activity at Vulsini, Vico, Sabatini volcanoes, and the entire activity of Amiata, and followed by less alkaline leucite-bearing and leucite-free shoshonitic volcanic rocks in the post caldera activity. The leucite-bearing ultrapotassic magmas are dominant over the late leucite-free magmas (i.e., shoshonitic to calc-alkaline magmas; Avanzinelli et al., 2009, and references therein).

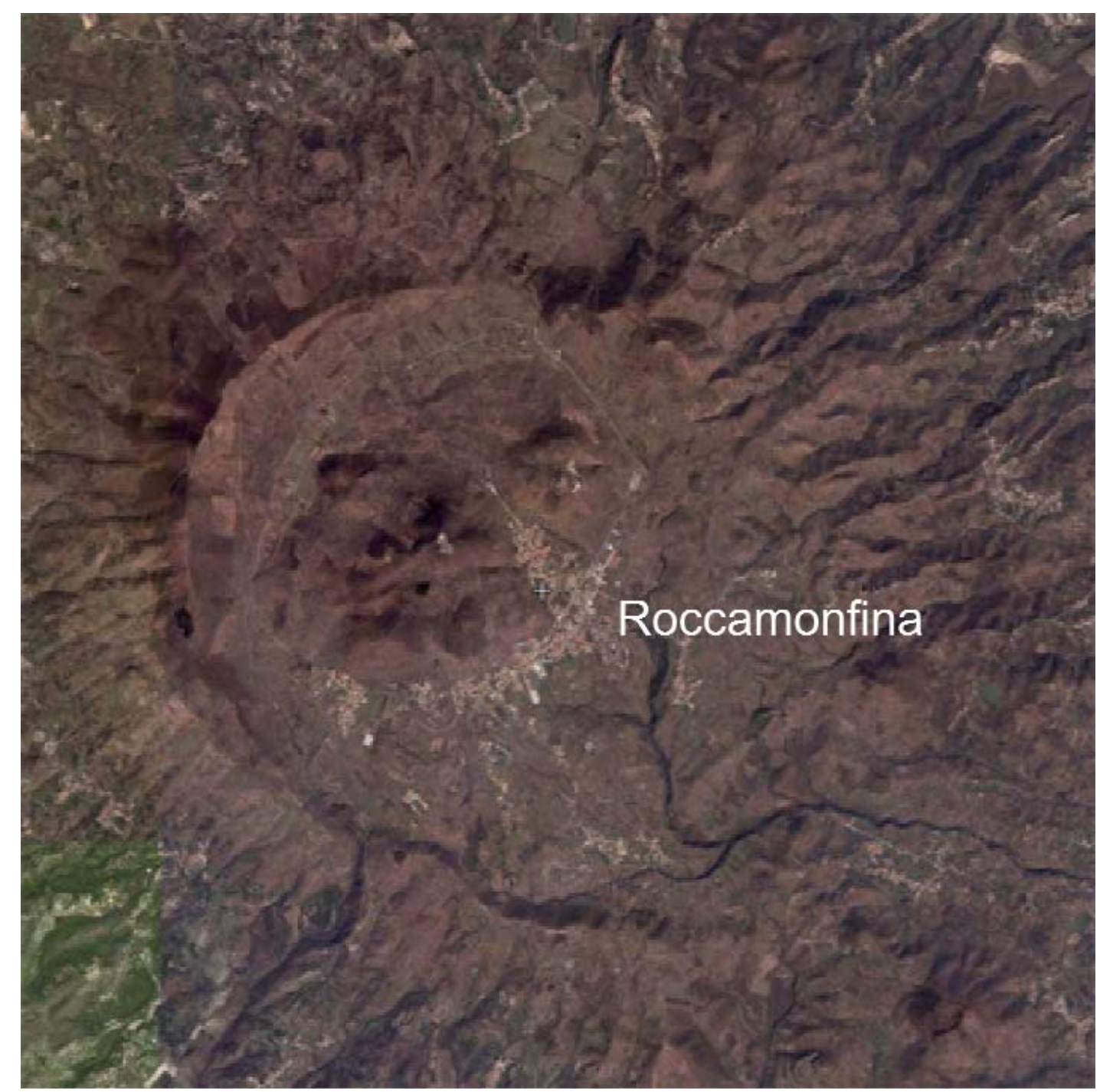

\section{Day 2 (continue): Roccamonfina Volcano}

Roccamonfina is a stratovolcano characterised by sector collapses and an apical central caldera (Fig. 42; Cole et al., 1992; De Rita \& Giordano, 1996; Giannetti, 2001; Rouchon et al., 2008). It belongs to the Roman Magmatic Province (Washington,

Fig. 54. Satellite image of Roccamonfina volcano. The strato-cone is cut at the top by the poly-phased summit caldera, which shows a well defined semi-circular rim to the west, due to a major sector collapse event occurred at ca. 400 ka (De Rita \& Giordano, 1996), and a more irregular rim to the East, due to the coalescence of other three main collapses (Cole et al., 1992; De Rita \& Giordano, 1996; Giannetti, 2001). The upper slope of the strato-cone is made of leucite-bearing lavas older than $400 \mathrm{ka}$, which are covered downslope by the main ignimbrites, emplaced between 385 and ca. 230 ka (Giannetti \& Luhr, 1983; Luhr \& Giannetti, 1987; Cole et al., 1993; Giordano 1998a,b; Giannetti \& DeCasa 2000). Post-caldera activity is characterised by emplacement of coalescent NE-trending leucite-free domes and lava flows are between 300 and $155 \mathrm{ka}$ (Conticelli et al., 2009b). 
1906; Peccerillo, 2005; Conticelli et al., 2009b; Avanzinelli et al., 2009), it is the southeasternmost volcanic centre of the Latian districts, and was the first volcano in which a "low potassium series" accompanying leucitebearing ultrapotassic rocks was recognized (Appleton, 1972).

The Roccamonfina Volcano is located at the intersection of a NE-SW extensional graben with regional NW-SE and N-S tectonic lineaments (Fig. 55), which cut the Mesozoic-Cenozoic Apennine carbonatic sequences (e.g., Giordano et al., 1995; De Rita \& Giordano, 1996). The volcanic succession lies on marine to continental sedimentary deposits that fill the NE-SW Garigliano graben (Watts, 1987; Giordano et al., 1995).

The Roccamonfina Volcano is made up of lavas and pyroclastic rocks erupted in three main phases of activity (Fig. 56; De Rita \& Giordano 1996; De Rita et al., 1998; Rouchon et al., 2008), which started at about 590 ka (Ballini et al., 1989a).

The first phase (stratocone building phase - Roccamonfina synthem) was dominated by emplacement of leucite-bearing lavas interbedded with deposits of mild explosive eruptions both from the central volcano and

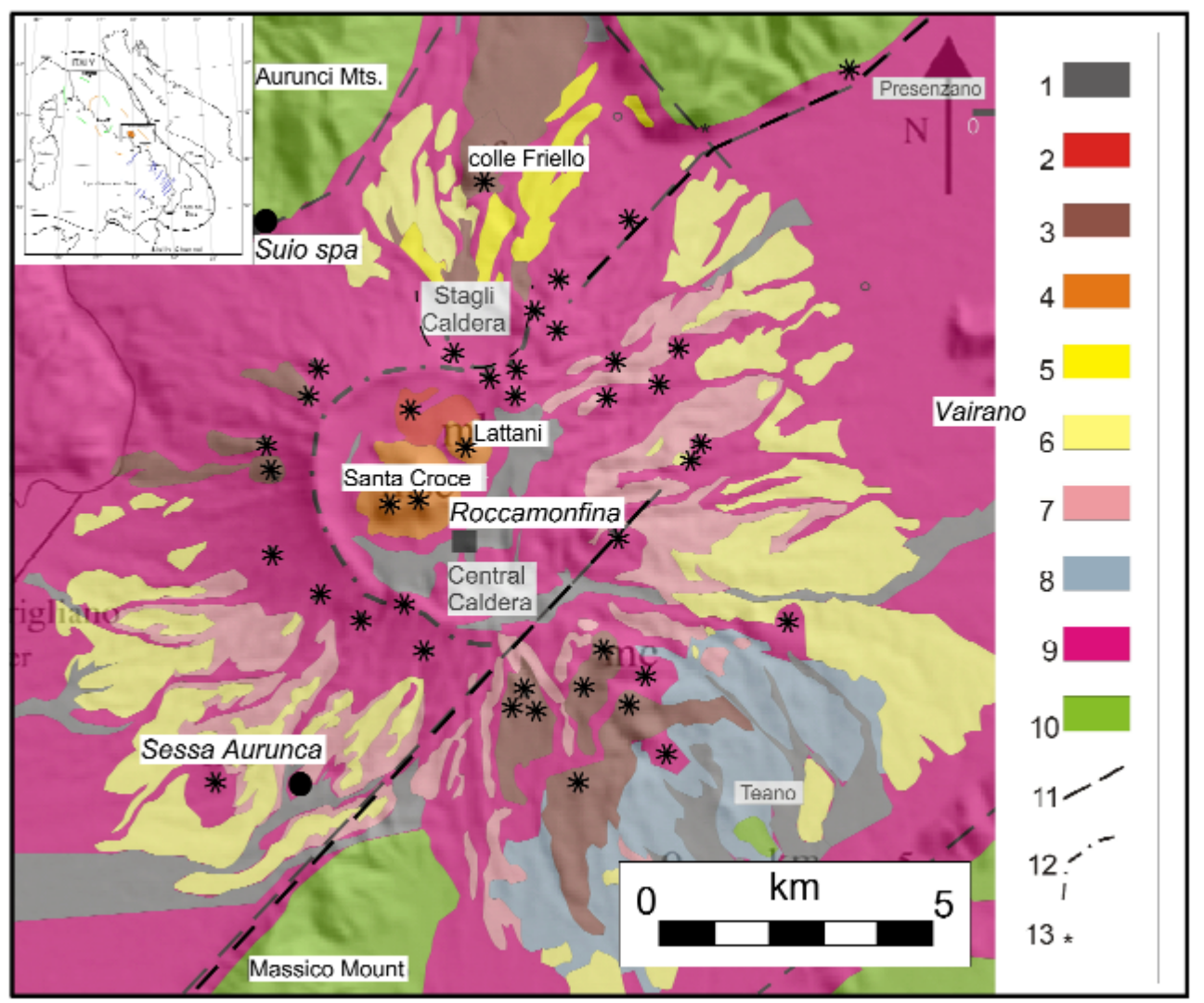
from parasitic monogenetic centres (Figs 55, 56). The volcanic rocks emitted have leucititic to plagio-leucititic affinities (former HKS of Appleton, 1972), ranging form

Fig. 55 - Geological sketch map of the Roccamonfina volcano. Legend: 1 - Campanian ignimbrite (erupted from Phlegrean Field); 2-5 Late phase of post-caldera activity (Vezzara synthem; 15550 ? ka); 2 - HKCA final lavas; 3 - Shoshonitic mafic lava and pyroclastic rocks from monogenetic centers; 4 - Shoshonitic domes; 5 - Yellow trachytic tuff; 6-8 - Early phase of post-caldera activity (Riardo synthem; 385-230 ka); 6 - White trachytic tuffs; 7 - Teano pyroclastic succession; 8 - Brown leucitic tuff; 9 Precaldera activity leucite-bearing lava and pyroclastic rocks (Roccamonfina synthem; 630-385 ka); 10 - Mesozoic-Cenozoic pre-orogenic carbonate-terrigenous succession; 11 - Main extensional faults; 12 - caldera rim; 13 - scoria cones. Boxed numbers refer to stop locations for this field itinerary (after Giannetti, 1964; De Rita \& Giordano, 1996; Giordano et al., 1998a, b; Conticelli et al., 2009b). 


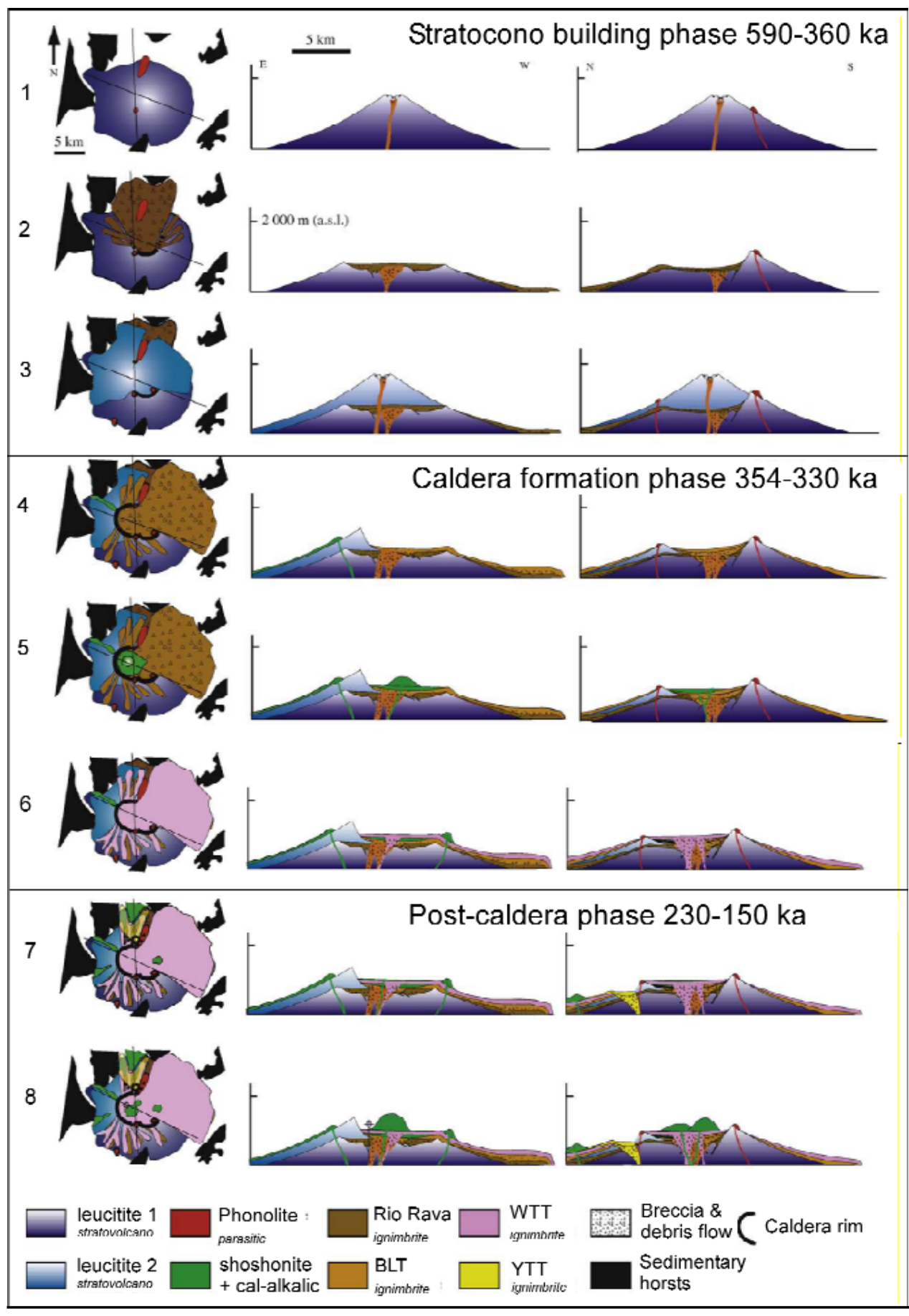

Fig. 56 - Reconstruction of the Roccamonfina Volcano history. Stratocone building period: 1) Pre-Rio Rava plagio-leucititic lavas and tephra of the stratovolcano; 2) Post-Rio Rava collapsed structure; 3) Pre-BLT plagioleucititic strato-volcano. Calderaforming period: 4) Post-BLT collapsed structure; 5) Pre-WTT construction stage; 6) Post-WTT. Post-caldera period: 7) PostYTT; 8) intracaldera dome and lava emplacements. (Redrawn after Rouchon et al., 2008).

basanite to phonolite (Fig. 57), made of olivine, clinopyroxene, leucite, plagioclase, Ba-phlogopite, apatite, Ti-magnetite, and minor amphibole, with sanidine and rare sodalite as accessory phase. A lateral sector collapse (Rio Rava ignimbrite) of the stratocone at $440 \mathrm{ka}$ formed a large horse-shoe shaped depression open to the East (De Rita \& Giordano, 1996; Rouchon et al., 2008), but leucite-bearing volcanic activity did not end and continued with the building up of a new stratocone, which almost completely covered the old volcano-tectonic depression (Di Girolamo et al., 1991; De Rita \& Giordano, 1996; Giannetti, 2001).

The second period of activity (caldera-forming period Riardo synthem; De Rita \& Giordano, 1996), was characterised by intermediate volume (1-10 $\left.\mathrm{km}^{3}\right)$ plinian eruptions, with the eruption of five main, caldera-forming ignimbrites, which are known, in stratigraphic order, as the brown leucitic tuff (BLT) and the succession of the white trachytic tuffs (WTTs) 
Fig. 57 - Classification and geochemical characteristics of the Roccamonfina volcanic rocks. A) Total Alkali-Silica (TAS) classification diagram (Le Maitre, 2002). B) Incompatible trace element patterns for mafic volcanic rocks normalised to the primordial mantle values of Sun \& McDonough (1989). Data from Ghiara et al. (1973) Ghiara \& Lirer (1977), Hawkesworth \& Vollmer (1979), Vollmer \& Hawkesworth (1981), Rogers et al. (1985); Giannetti \& Luhr (1983), Luhr \& Giannetti (1987), Conticelli \& Peccerillo (1992); Giannetti \& Ellam (1994); Conticelli et al. (2002, 2007, 2009b), Rouchon et al. (2008).

(Giannetti \& Luhr, 1983; Luhr \& Giannetti, 1987; Ballini et al., 1989b; Cole et al., 1992, 1993; De Rita et al., 1998; Giordano 1998a,b; Giannetti \& De Casa, 2000). The pyroclastic units have variable compositions from phonolitic to trachytic. Recent K/Ar and 40Ar-39Ar ages of the brown leucitic tuff converged at $350 \mathrm{Ma}$ (Fig. 57; Rouchon et al., 2008; Scaillet et al., 2008). The white trachytic tuffs succession ranges between 320 and 230 ka (Giannetti \& De Casa, 2000; Ballini et al., 1989a; Rouchon et al., 2008). The largest compositional range is observed among the juvenile clasts of the brown leucitic tuff, which may include the effect of weathering (Giannetti \& Masi, 1989). The white trachytic tuffs fall well within the trachytic field (Fig. 56).

The third and last period was post-caldera activity, which was characterised by dome to monogenetic volcanism (e.g., cinder cones, dome, and lava flows) within the caldera, along its edge and on the flanks of the Roccamonfina stratocone (Figs 55-56). Geochronologic data performed on the rocks of this period do not allow to deliver the exact age of lava flows that originated from a fracture on the western flank of Monte Santa Croce Dome and flowed down the middle of the caldera at the foot of Monte Lattani dome. Monte Santa Croce dome yielded the youngest ages found at Roccamonfina (K/Ar, 160 ka, Radicati et al., 1988; 150 ka, Rouchon et al., 2008). Samples from cinder, scoria cones and lava flows on the caldera rim and external to the caldera range between 330 ka (Casale Robetti; 40Ar-39Ar; Conticelli et al., 2009b, 2010a) and 270 Ma (Colle Friello;

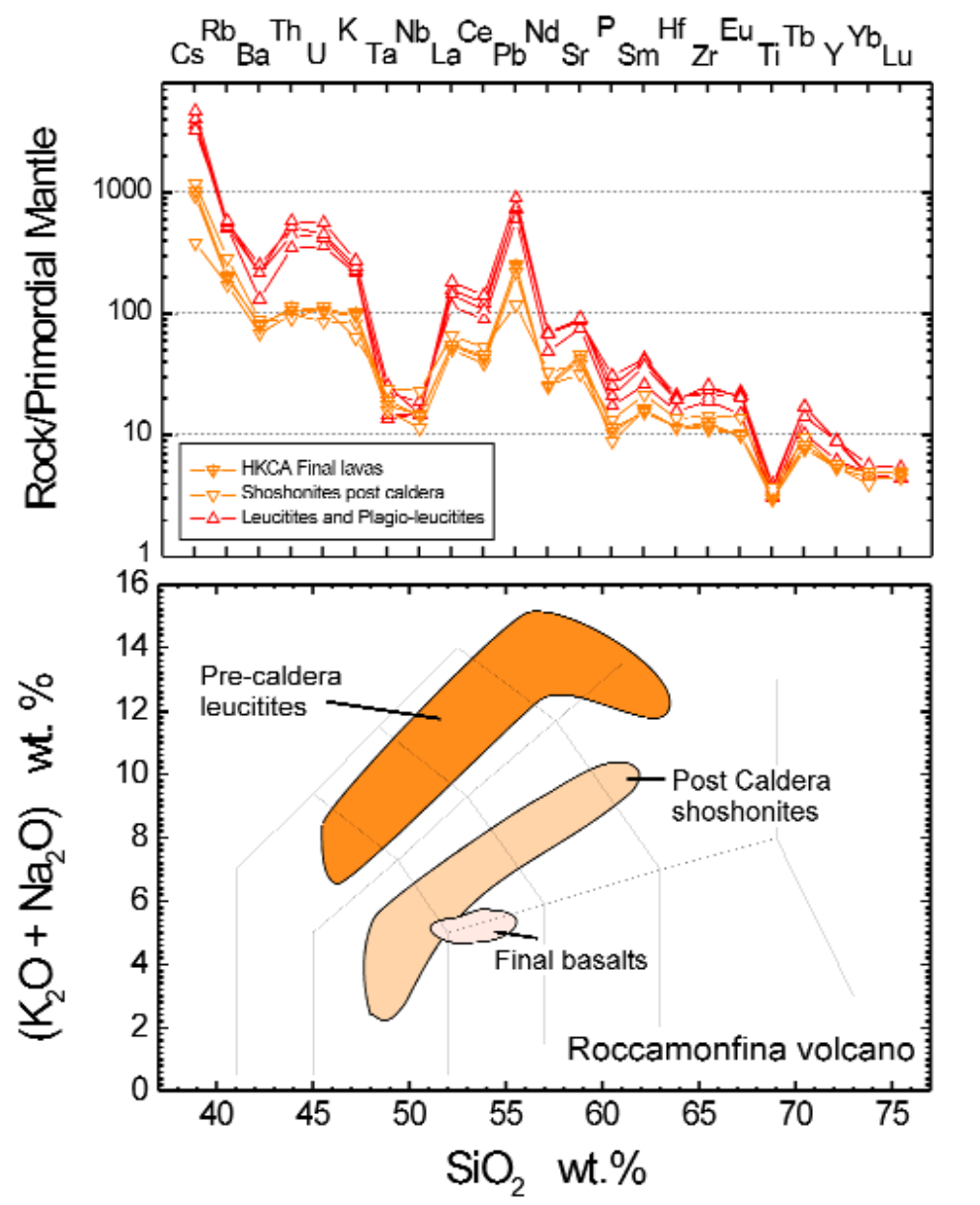

81 
$\mathrm{K} / \mathrm{Ar}$, Rouchon et al., 2008). Post caldera volcanic rocks are leucite-free (Fig. 58) mostly with shoshonitic affinity. Santa Croce and Lattani mounts are two intracaldera domes aligned along a NE-SW trend. The youngest leucite-free lava flows, which have been vented from a fracture on a flank of Monte Santa Croce dome, have revealed compositional variations pointing to the HK-calc-alkaline field (Conticelli et al., $2009 \mathrm{~b}$ ).

\section{Leucite-bearing pre-caldera activity}

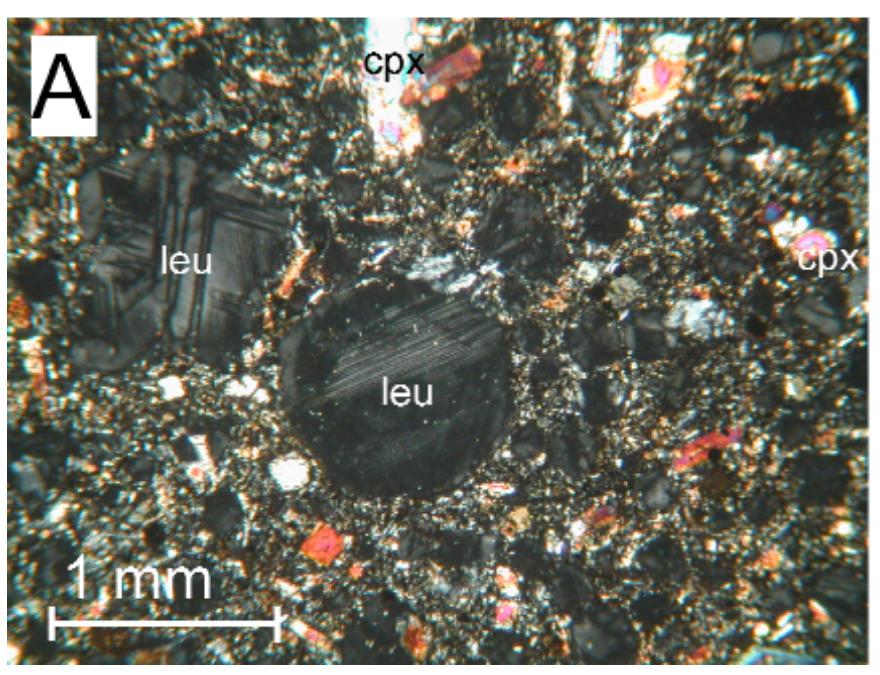

\section{Leucite-free} post-caldera activity

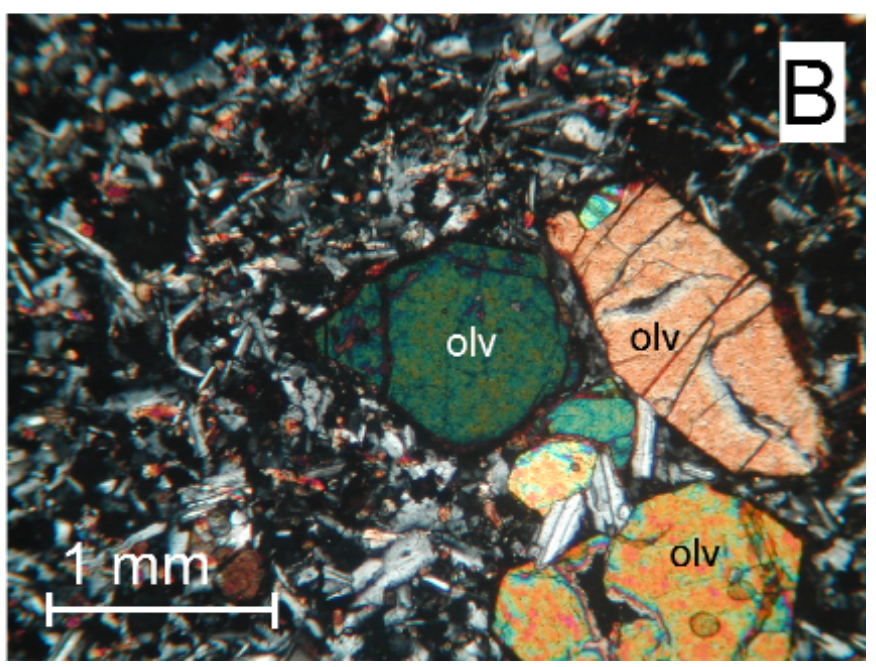

Fig. 58 - Thin sections of preand post-caldera lavas. Note the occurrence in A of leucite (leu) phenocrysts set in a microcrystalline groundmass made of clinopyroxene $(\mathrm{cpx})$, plagioclase, and leucite. Thin section of trachybasalt from Monte Santa Croce lava flows with olivine phenocrysts set in an intersertal groundmass made of plagioclase, clinopyroxene and olivine (B).

Beccaluva et al. (1991) pointed out that ultrapotassic rocks cropping out below the 41st parallel display clear differences in trace element distribution with respect to those from above this parallel. The Roccamonfina Volcano, is just few degree North of the $41^{\text {st }}$ parallel and ultra-potassic leucite-bearing rocks have incompatible trace element distribution similar to that of the other Latian districts. The post-caldera shoshonitic rocks from Roccamonfina have instead significantly lower LILE with respect to any other Roman rocks and in particular to the other post-caldera shoshonites of the northernmost Latian districts. In this regard the Roccamonfina postcaldera rocks display trace element similarities with rocks from the Neapolitan district and to a lesser extent with those from Lucanian Magmatic Province (Conticelli et al., 2009b). The leucite-bearing pre-caldera ultrapotassic rocks have no significant compositional differences with other Roman volcanic rocks of the Latian districts. In summary, composition of magmas at Roccamonfina changes with time due to the arrival of a new metasomatic component in its source. 
The Stops of the afternoon of the 2 nd day

You will reach the Roccamonfina area from the Campi Flegrei driving through the main paytool highway "A1" (E45 European classification) direction towards Rome, taking the exit at Caianello, then follow signs to Roccamonfina. Once reached the village you will leave it in direction of the "Madonna dei Lattani" sanctuary. The Roccamonfina village is built within the main central caldera at the foot of the two Santa Croce and Lattani domes.

Fig. 59 - Location of stops of the afternoon of the second day at Roccamonfina Volcano. Dashed line shows the limit of the calderas.
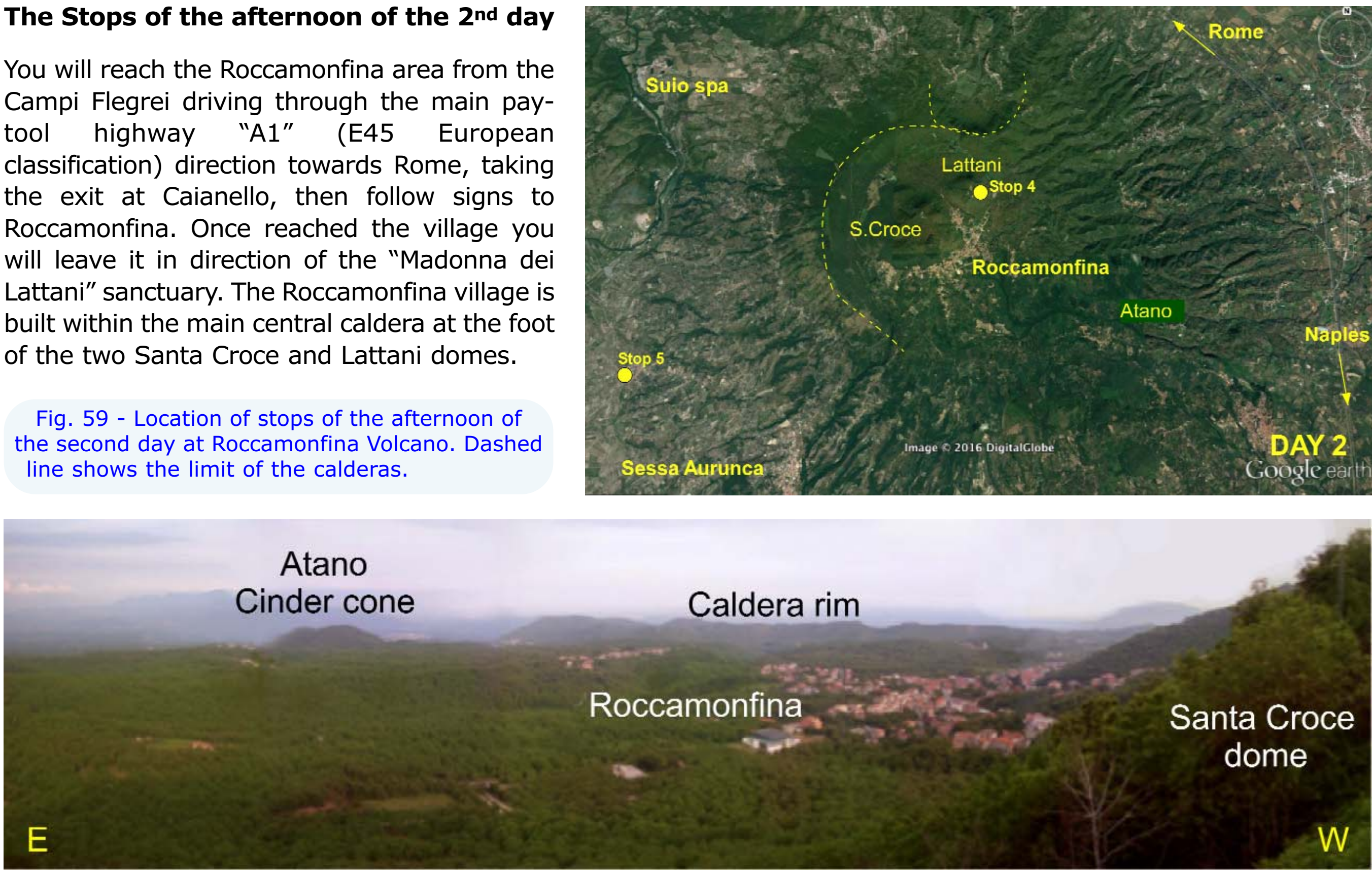

Fig. 60 - Lookout toward the Roccamonfina central caldera from the Santa Maria dei Lattani Monastry (Photo: G. Giordano). 


\section{STOP 2.4: Monte Lattani and the post-caldera activity}

Santa Croce and Monte Lattani are two main intracaldera domes that were built at around $155 \mathrm{ka}$. The domes are aligned along a NE-SW trend that projects across and outside the main summit collapse caldera (Fig. 55), identifying a major tectonic trend that controlled the whole history of Roccamonfina Volcano and parallels the main Garigliano graben. The domes are endogenous, and paleo-caldera volcaniclastic lake sediments are found uplifted along the outer slopes of the dome. The dome lava is latitic in composition, grey in colour and porphyritic. The mineral assemblage is made of Sd + Plg + Cpx + Bio[resorbed] + Opaques with accessory apatite, titanite and perrierite.

The beauty of this location and the majesty of its panorama inspired the construction of a Sanctuary on the Madonna dei Lattani $\left(41^{\circ} 18^{\prime} 10^{\prime \prime} \mathrm{N}-13^{\circ} 59^{\prime} 06^{\prime \prime} \mathrm{E}\right)$ built on the Lattani dome, at $805 \mathrm{~m}$ a.s.I., in the XVth century. The Sanctuary terrace faces East, and from there the shape and main features of the collapse calderas at the summit of Roccamonfina Volcano can be observed. The nearby Apennines can also be seen across the caldera rim.

STOP 2.5: Sessa Aurunca, the calderaforming ignimbrites $\left(41^{\circ} 15^{\prime} 02^{\prime \prime} \mathrm{N}-\right.$ $13^{\circ} 55^{\prime 2} 22^{\prime \prime} \mathrm{E}$ )

The slopes of the southwestern sector of the volcano are covered by the succession of ignimbrites that characterised the activity of the volcano between 385 and $230 \mathrm{ka}$, during which five main ignimbrites

Fig. 61 - Distribution of WTTs Cupa flow unit on the SW slope and its location with respect to the caldera of Roccamonfina. Measured stratigraphic sections are used to correlate the radial crosssection (from Giordano, 1998).

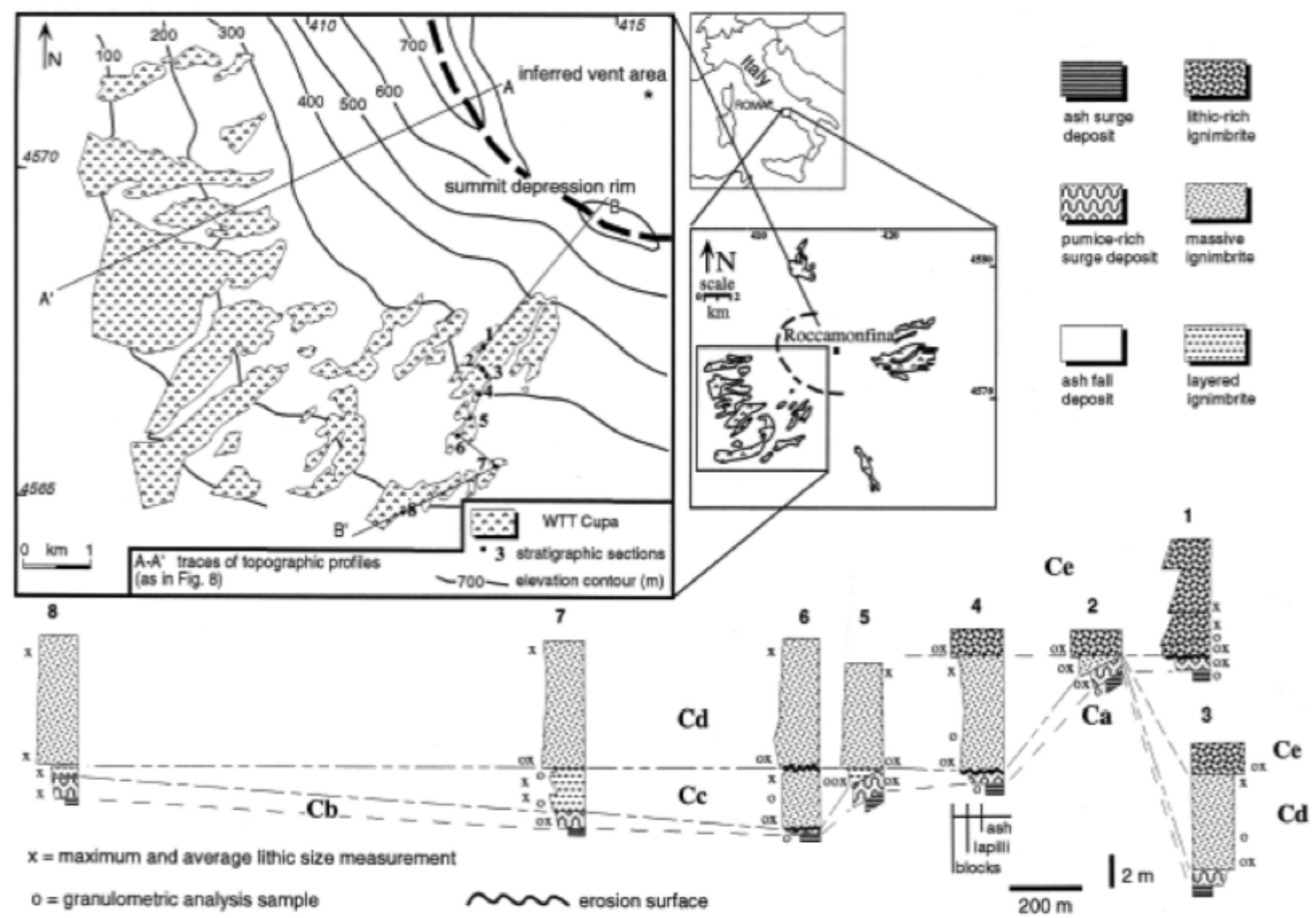


were emplaced (Fig. 61), from older to younger, the brown leucitic tuff (BLT), and the succession of four white trachytic tuffs (Giordano, 1998a): the WTT Cupa, the WTT Aulpi, the WTT S. Clemente and the WTT Galluccio. The ignimbrites are characteristically underlain by pumice lapilli fall deposit, largely dispersed to the E-SE, and their lithofacies range from massive and chaotic lapilli-tuff, to faintly stratified. The thicknesses usually exceed $10 \mathrm{~m}$, although the time interval between each caldera-forming eruption, on average $30 \mathrm{ka}$, allowed significant re-incisions of the palaeovalley network (Fig. 62), so that successive ignimbrites are usually valley confined and laterally juxtaposed to the previous ones. For this reason, the succession of the WTTs has been long believed to be made of just one main unit. Co-ignimbrite lithic breccias, which include a significant proportion of syenite blocks, are common in the BLT, the WTT Cupa and the WTT Galluccio that are also the largest in volume, estimated between 1 and $10 \mathrm{~km}^{3}$ each; hence these ignimbrites represent the best candidates for the major collapses at the summit caldera.

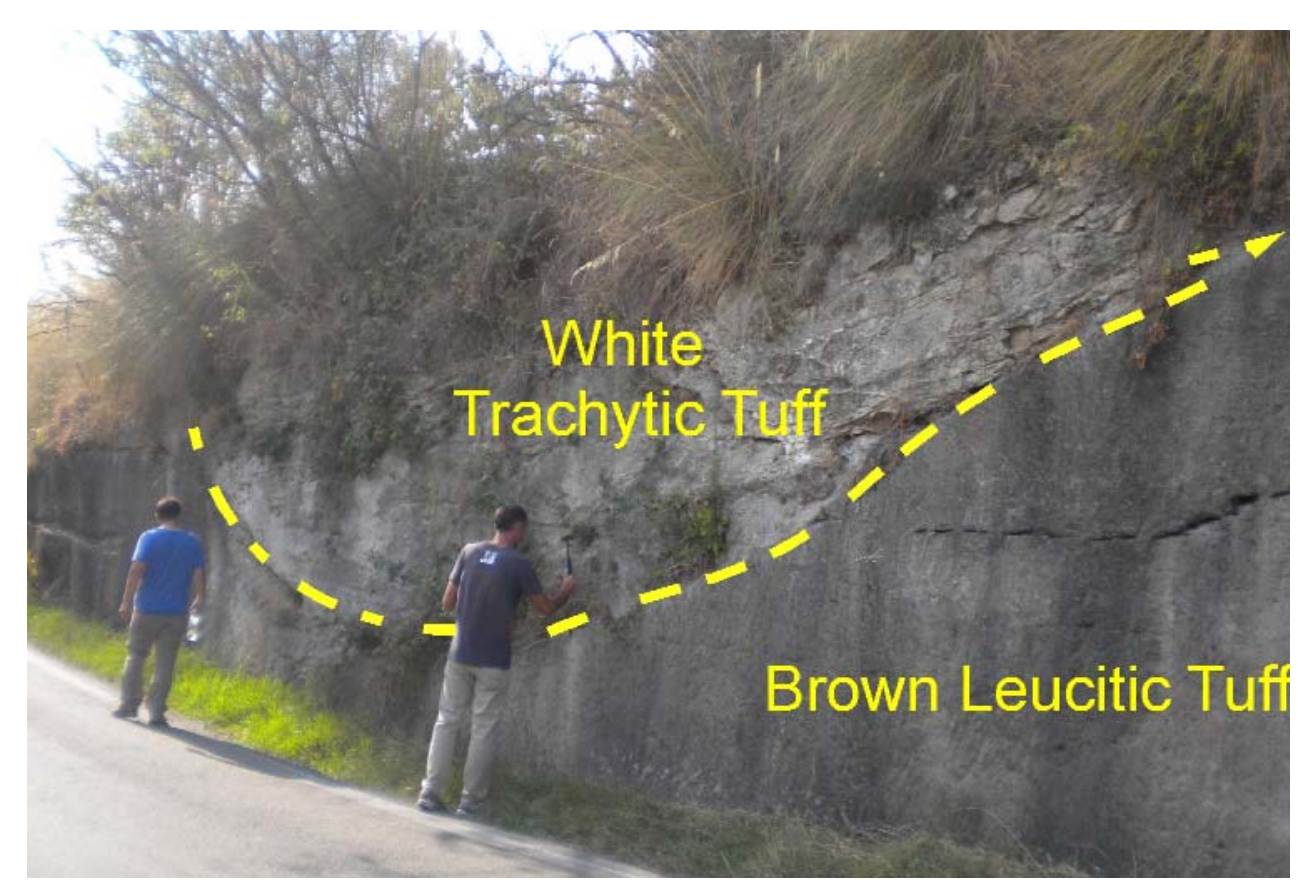

Fig. 62 - South-West slope of the Roccamonfina Volcano nearby Sessa Aurunca village. Channel excavated within the BLT; The main caldera forming ignimbrites at Roccamonfina Volcano were erupted between 400 and $230 \mathrm{ka}$. The lower ignimbrite is known as brown leucitic tuff (BLT) and is made of largely zeolitised massive and chaotic units that along the SW flank of Roccamonfina Volcano are covered by the succession of the white trachytic tuffs (WTTs). The photo shows a well exposed erosional contact between the BLT, at the bottom, and the first of the WTT ignimbrites known as WTT Cupa. The large $\mathrm{U}$-shaped unconformity indicates that the erosion was largely due to the erosive power of the earliest WTT Cupa pyroclastic density currents (Photo: S. Conticelli). 


\section{Day 3: Colli Albani Volcano}

The Colli Albani Volcano is a quiescent volcano located to the South-Est of Rome (Giordano et al., 2006a, 2010, and references therein). Its volcanic activity started at approximately 600 ka (Karner et al., 2001a,b,c; Marra et al., 2009; Soligo \& Tuccimei 2010, and references therein). Both explosive and effusive products are remarkably undersaturated and ultrapotassic $\left(\mathrm{K}_{2} \mathrm{O}=7-10\right.$ wt.\%; $\mathrm{K}_{2} \mathrm{O} / \mathrm{Na}_{2} \mathrm{O}=3-8$; Trigila 1995; Boari et al., 2009a; Conticelli et al., 2010a, b). Geochemical and petrological studies indicate that the largest influence on the Colli Albani magma chemistry is associated with the mantle source regions, where different degrees of partial melting of metasomatic veins and surrounding mantle peridotite control the observed magma composition (Boari et al.,

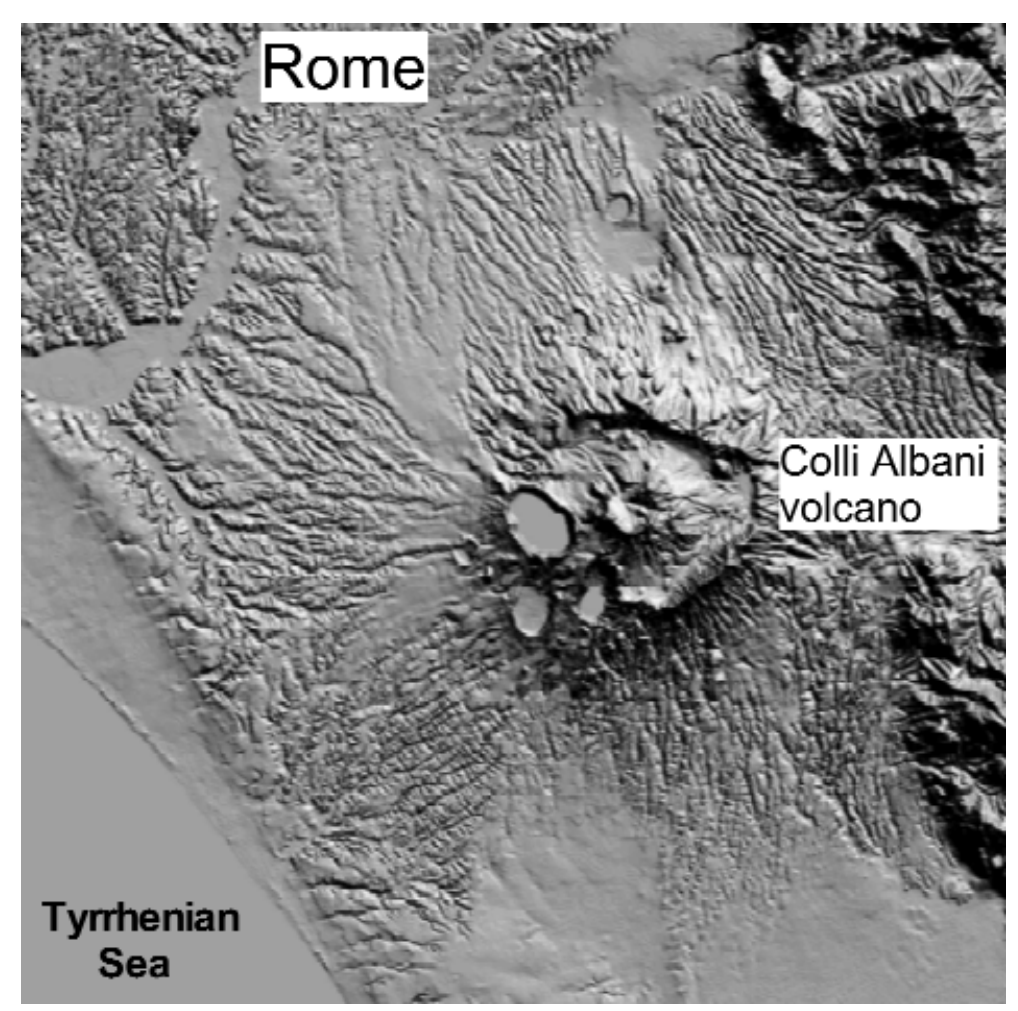

Fig. 63 - Digital Elevation Model of the "Colli Albani" Volcano. 2009a; Conticelli et al., 2010a,b). Differentiation and crustal assimilation also played a role at shallow magma chamber level (Freda et al., 1997, 2008; Dallai et al., 2004; Gaeta et al., 2006, 2009, 2011; Giordano et al., 2006; Boari et al., 2009b; Sottili et al., 2009; Di Rocco et al., 2012).

In spite of its very silica poor compositions $\left(\mathrm{SiO}_{2}\right.$ between $43 \mathrm{wt}$. \% and 54 wt.\%), the volcano displays several features identical to felsic volcanoes, including low aspect ratio ignimbrites tens of cubic kilometres in volume, and a related central, polyphased collapse caldera about $10 \mathrm{~km} \times 10 \mathrm{~km}$ in morphological diameter (Fig. 63). The shape of the caldera is controlled by the structural setting of the substrate (Funiciello \& Parotto, 1978; De Rita et al., 1995; Giordano et al., 2010).

The Colli Albani Volcano is located at the intersection of NW- and NEtrending fault systems (Fig. 53; Faccenna et al., 1994; Giordano et al., 2006). Gravimetric surveys indicate the occurrence in the subsurface of the NW-trending structural lows and highs of the Mesozoic-Cenozoic carbonatic and terrigenous succession, which constitutes the substratum of the volcano down to a depth of 5-6 km (Di Filippo \& Toro, 1980; Funiciello \& Parotto, 1978). Recent results from 3D 
techniques of inversion of earthquake-wave arrival times in this area indicate the presence of a cooling magma body beneath the volcano at depths between 6 and $18 \mathrm{~km}$ (Chiarabba et al., 1994; 2010). The most recent Holocene activity of the volcano was dominantly phreatic, involving catastrophic uprise and outflows of the Albano maar lake up until Ancient Roman times (Funiciello et al., 2003; De Benedetti et al., 2008). The volcano presently shows signs of unrest such as frequent shallow seismicity of low or very low magnitude ( $M \leq 3.5$ ), local uplift and significant degassing (Chiarabba et al., 1997; Carapezza et al., 2003, 2007, 2012).

\section{Eruptive history}

The volcano is made of several superposed edifices, each characterised by a distinctive morphology, dominant eruptive style, magma chemistry and erupted volumes. The recognised edifices are, from oldest to youngest: the Vulcano Laziale caldera complex, the Tuscolano-Artemisio ring-fracture system, the Faete intracaldera stratovolcano, the Via dei Laghi maar complex (Figs 64 and 65).

Fig. 64 - Schematic Geological Map of the Colli Albani Volcano (Giordano et al., 2010a); Legend: 1, 2) alluvial deposits; 3) travertine; 4) Tavolato formation; 5) Albano maar; 6) Nemi maar; 7) other maars; 8) subplinian fall deposits; 9) lower Faete succession; 10) upper Faete succession; 11) Tuscolano Artemisio (T.A.) scoria cones; 12) T.A. welded scoria; 13) T.A. lavas; 14, 15) Pantano Borghese scoria and lavas; 16, 17) Santa Maria delle Mole scoria and lava; 18, 19) plateau lavas and ignimbrites; 20) Sabatini volcanic products; 21 , 22) sedimentary sequences; 23) caldera rim; 24) cinder cones; 25) maars; 26) inferred caldera rim.

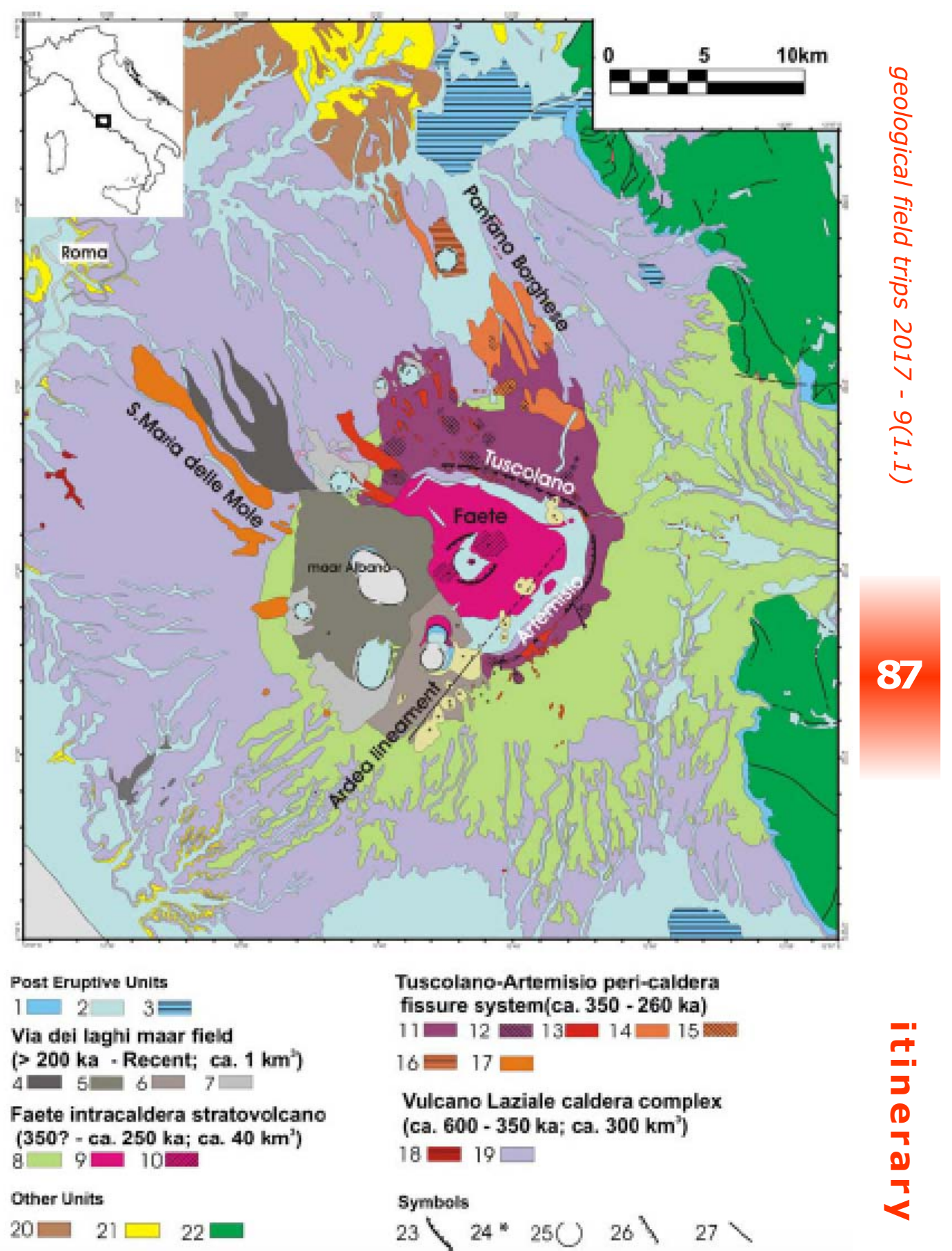




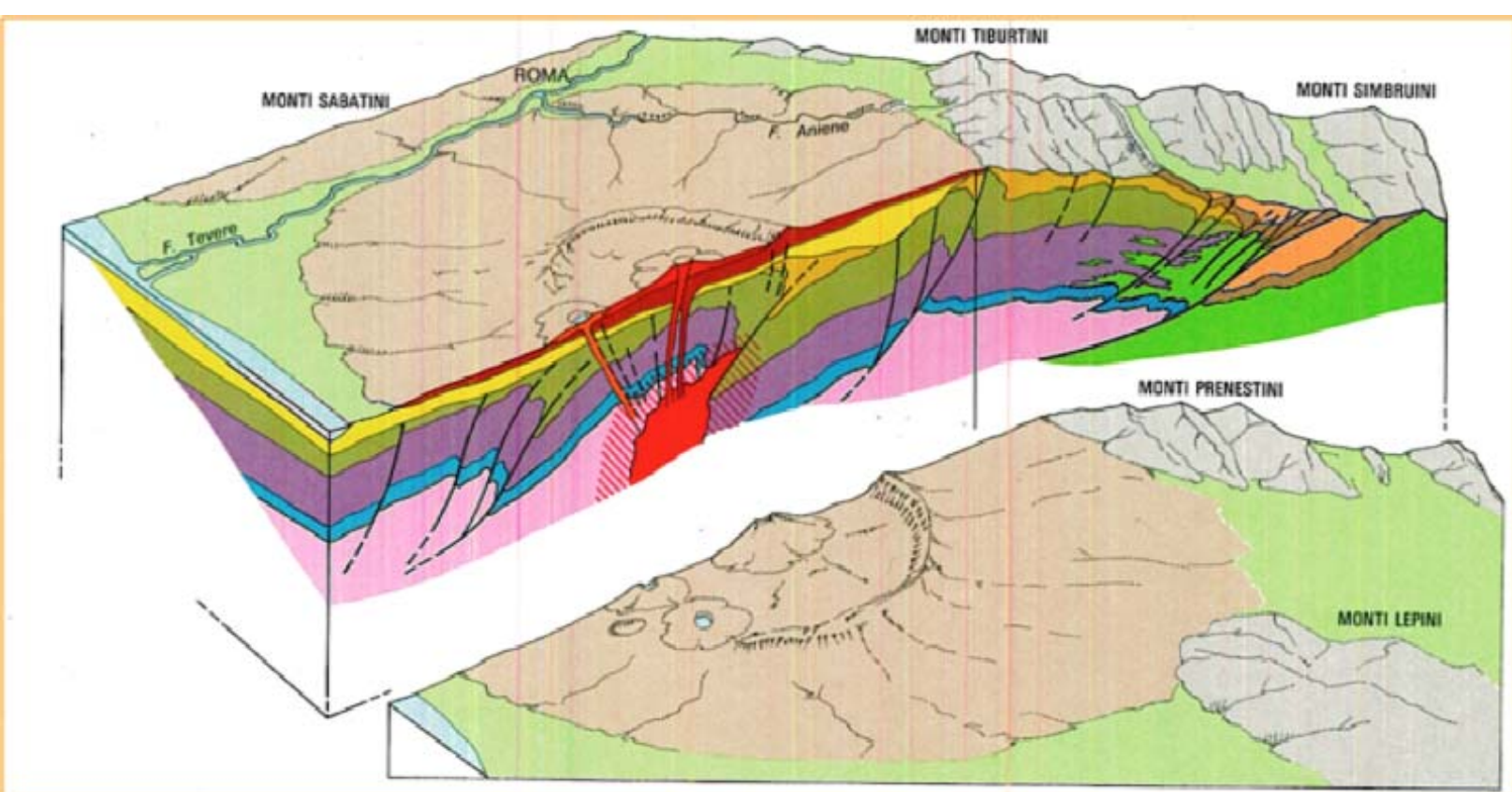

Fig. 65 - Interpretative block diagram of the Colli Albani Volcano and its substrate (courtesy of M. Parotto).
Vulcano Laziale caldera complex

The Vulcano Laziale caldera complex is characterised by an ignimbrite shield, more than $2000 \mathrm{~km}^{2}$ wide, circularly distributed around the central caldera (Fig. 64). It was formed by the vertical aggradation of the largest low aspect ratio ignimbrites erupted from the Colli Albani, interbedded with scoria fall deposits, lava flows and volcaniclastic deposits, for a compound volume of ca. $280 \mathrm{~km}^{3}$ (Diano et al., 2010). The ignimbrites form a gently sloping $\left(2^{\circ}-5^{\circ}\right)$ plateau, inclined outward from the central caldera. The ignimbrites were erupted between $>561 \mathrm{ka}$ and $355 \mathrm{ka}$ (Karner et al., 2001a). The lower ignimbrites (Trigoria unit, Tor de' Cenci unit, Palatino unit, Casale del Cavaliere unit) display distinctive phreatomagmatic features, such as abundant ( $>70$ vol.\%) blocky shaped fine ash and ubiquitous presence of accretionary lapilli, related to interaction with an early caldera lake, within the "Pisolitic Tuffs succession" (De Rita et al., 2002; Giordano et al., 2010). By contrast, the upper ignimbrites (i.e., pozzolane nere, pozzolane rosse and Villa Senni ignimbrites) are typically 10-80 m thick scoria and ash flow deposits. Detailed descriptions of most of these ignimbrites can be found in several papers (Fornaseri et al., 1963; Giordano \& Dobran, 1994; De Rita et al., 1995; Freda et al., 1997, 2011; Palladino et al., 2001; Watkins et al., 2002; Giordano et al., 2006a, 2010; Vinkler et al., 2012). Extensive lava flows interbedded within the main ignimbrites formed large plateaux such as the Vallerano and the San Vittorino lavas (ca. 460 ka; Karner et al., 2001a).

The Faete intracaldera stratovolcano and the Tuscolano-Artemisio ring-fracture system

After the last caldera-forming eruption at 355 ka (Villa Senni ignimbrite), the volcano dramatically changed its volcanic style and feeding system, with the arrival to the surface of largely degassed magmas along several different 
pathways. Lavas of the post-caldera period have been dated between 0.35 and $0.15 \mathrm{Ma}$ (Karner et al., 2001b, Marra et al., 2003). Five main sectors of post-caldera volcanic activity have been recognised (Giordano et al., 2006a, 2010; Boari et al., 2009a) and produced ca. $40 \mathrm{~km}^{3}$ of erupted products, dominantly lavas and strombolian deposits (Fig. 64): i) the Monte delle Faete, which is the intracaldera stratovolcano ( $944 \mathrm{~m}$ a.s.I.); ii) the Tuscolano Artemisio ringfracture system, which is made of coalescent scoria cones and lava flows aligned along circum-caldera fractures; iii) the NW-trending Pantano Borghese monogenetic alignment, external to the caldera rim on the NE sector of the volcano (Fig. 66); iv) the NW-trending Santa Maria della Mole monogenetic alignment, which is external and parallel to the caldera rim on the $\mathrm{W}$ sector of the volcano; $\mathbf{v}$ ) the NE-trending Monte Due Torri-Ardea monogenetic alignment, which extend almost radially away from the Southwestern caldera margin.
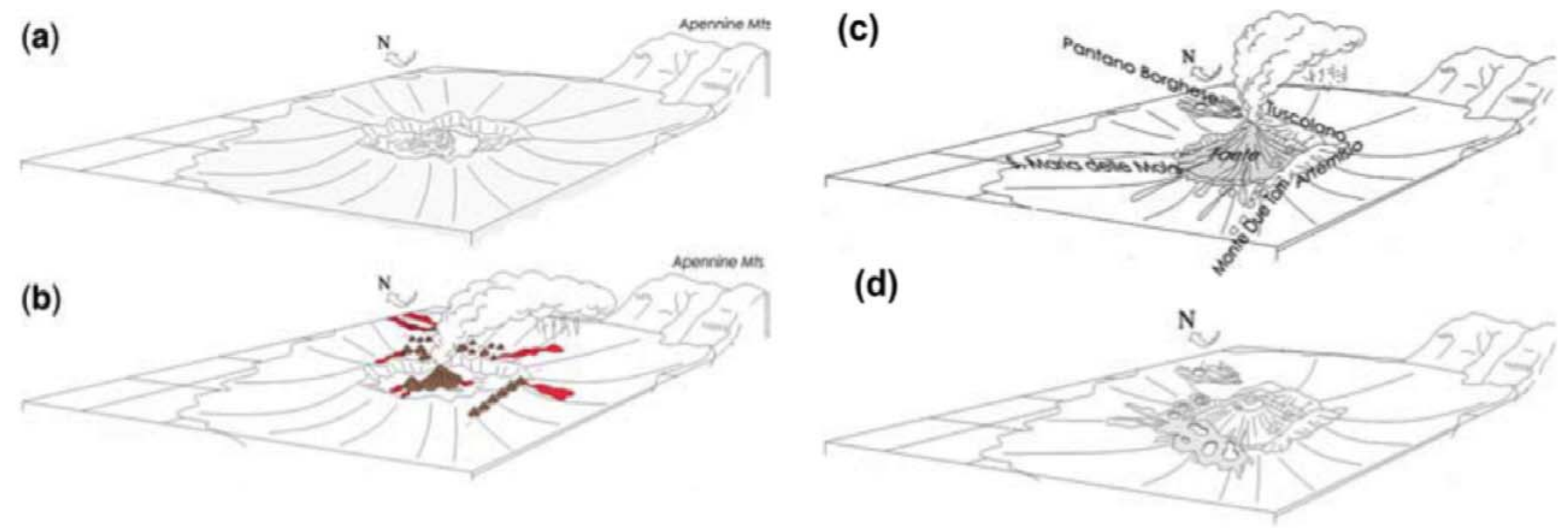

Fig. 66 - Reconstruction of the Vulcano Laziale caldera complex (600-355 ka). a) Immediately post-collapse the volcano was characterized by the collapsed caldera and the ignimbrite outflow sheet. b) During inter-ignimbrite periods (i.e. post-caldera to each major eruption), the volcano was characterized by peri-caldera and extracaldera fissure eruptions (scoria cones and lava flows), as well as by the formation of intracaldera volcanoes with both effusive and explosive style; $\mathbf{c}$ ) this reconstruction also, of course, refers to the post-Villa Senni caldera collapse ( $<355 \mathrm{ka}$ ) and is therefore relevant to the Tuscolano-Artemiso peri- and extra-caldera fissure system, as well as the Faete intra-caldera stratovolcano; d) the most recent activity was confined to the west of the ring-fracture system dominated by phreatomagmatic eruptions, which produced the Via dei Laghi maar complex $(<200 \mathrm{ka})$. 
Via dei Laghi maar complex

The Via dei Laghi maar complex includes all products related to the mostly phreato-magmatic eccentric activity, which has characterised the Colli Albani activity since approximately 200 ka (Funiciello et al., 2003, 2010; Freda et al., 2006; De Benedetti et al., 2008; Giordano et al., 2010). It is made by several overlapping maars, located along the western and northern slope of the volcano (Fig. 63). The maars of Valle Marciana, Pantano Secco, and Prata Porci are monogenetic, whereas those along the western slope of the volcano (e.g., Albano, Ariccia, Nemi) are poligenetic. There are also scoria cones and tuff cones interbedded with the maar deposits. The localisation of the maars can be related to the presence, at relatively shallow depth (below 1-2 $\mathrm{km}$ ), of the geothermal aquifer of the Ciampino carbonatic horst (Funiciello \& Parotto, 1978). Furthermore, the significant reduction of the total erupted volumes (about $1 \mathrm{~km}^{3}$ ) may have favoured the realisation of higher water-magma ratios and the efficiency of the interaction.

Chemical and petrographic characteristics of Colli Albani rocks

The most striking feature of the Colli Albani rocks is their silica-undersaturated character, which is stronger than other leucitites and plagio-leucitites of the Roman Province, their higher contents of $\mathrm{MgO}, \mathrm{CaO}$ and incompatible trace element (Fig. 66), and the lack of extremely differentiated rocks such as phonolites and trachy-phonolites. The latter is also true for ignimbrites, which have chemical compositions never exceeding tephritic-phonolite (Conticelli et al., 2010b); some of them (i.e., pozzolane rosse, pozzolanelle) show phonolitic tephrite and tephrite compositions as well (Fig. 66). These features are the major difference with other Roman volcanoes of the Latian districts, where ignimbrites have invariably phonolitic to trachyphonolitic compositions. Such mafic chemical characteristics of the magmas involved in Colli Albani ignimbritic eruptions were thought to represent a problem due to the possible lack of volatiles necessary to trigger paroxysmal eruptions (Freda et al., 1997, 2011). To tackle this issue, carbonate syntexis has been suggested to supply the needed $\mathrm{CO}_{2}$ to trigger paroxysmal eruptions (e.g., Freda et al., 2007; Iacono Marziano et al., 2007, 2008; Gaeta et al., 2009), although such a process would have enriched the $\mathrm{CaO}$ and dramatically diluted the $\mathrm{MgO}$ and incompatible trace element contents of the magmas (Peccerillo, 1998, 2004, 2005b), features that are not observed in Colli Albani rocks (Boari et al., 2009a). Sedimentary carbonate assimilation has been widely discussed by several authors who found in some specific cases evidence to support it, but in other cases questioned this differentiation process (e.g. Boari et al., 2009a; Peccerillo et al., 2010; Conticelli et al., 2010b). 
The extreme enrichments of $\mathrm{MgO}, \mathrm{CaO}, \mathrm{K}_{2} \mathrm{O}$, and related incompatible elements brought the Colli Albani magmas to have lower silica activity and alumina saturation than other Roman ones, so that they were able to crystallise melilite and other REE-rich accessory minerals, and instead to prevent crystallisation of plagioclase and K-feldspar (Federico et al., 1994; Conticelli et al., 2010b).

Leucite is among the most abundant phenocrysts in pre-caldera pyroclastic rocks and in the Monte delle Faete lavas and pyroclastic rocks, whereas it is confined in the groundmasses of pre-caldera plateau melilititic lavas, and post-caldera ones. Clinopyroxene is a ubiquitous phenocryst, often showing complex zoning (Aurisicchio et al., 1988; Gaeta et al., 2006). Olivine is confined to the most mafic pre- and post-caldera lavas and, like in all other ultrapotassic volcanoes, it has euhedral chromite inclusions. In the groundmass beside minerals found as phenocrysts, Ba-phlogopite, Ti-magnetite, nepheline, Ca-Fe olivines and apatite are also found (e.g., Gaeta et al., 2000; Conticelli et al., 2010b; Melluso et al., 2010). Åkermanitic melilite crystals are confined to the groundmasses of most silica undersaturated foidites of the pre- and post-caldera periods. The Capo di Bove (e.g., cecilite, Washington, 1906) and the Osa foidites are the best examples among postcaldera lavas. Melanite garnet, gehlenitic melilite and Al-spinel are typical minerals of skarn ejecta (Federico \& Peccerillo, 2002) and they are found as xenocrysts in pyroclastic rocks of the Via dei Laghi hydromagmatic activity (Conticelli et al., 2010b).

The spiderdiagram normalised to primordial mantle (Fig. 67) shows significant differences between mafic MgO-rich magmas from pre- to post-caldera activity. Indeed, pre-caldera leucititic and melilititic magmas

Fig. 67 - Classification and geochemical characteristics of the Colli Albani volcanic rocks. Bottom: Total Alkali-Silica (TAS) classification diagram (Le Maitre, 2002); Top: spiderdiagrams for mafic volcanic rocks normalised to the primordial mantle values of Sun \& McDonough (1989). Data from Fornaseri \& Scherillo (1963); Laurenzi (1980); Peccerillo et al. (1984); Ferrara et al. (1985); Francalanci et al. (1987); Trigila (1995); Freda et al. (1997, 2006); Palladino et al. (2001); Conticelli et al. (2002, 2007, 2010b); Gaeta et al. (2006); Giordano et al. (2006a); De Benedetti et al. (2008); Boari et al. (2009a).
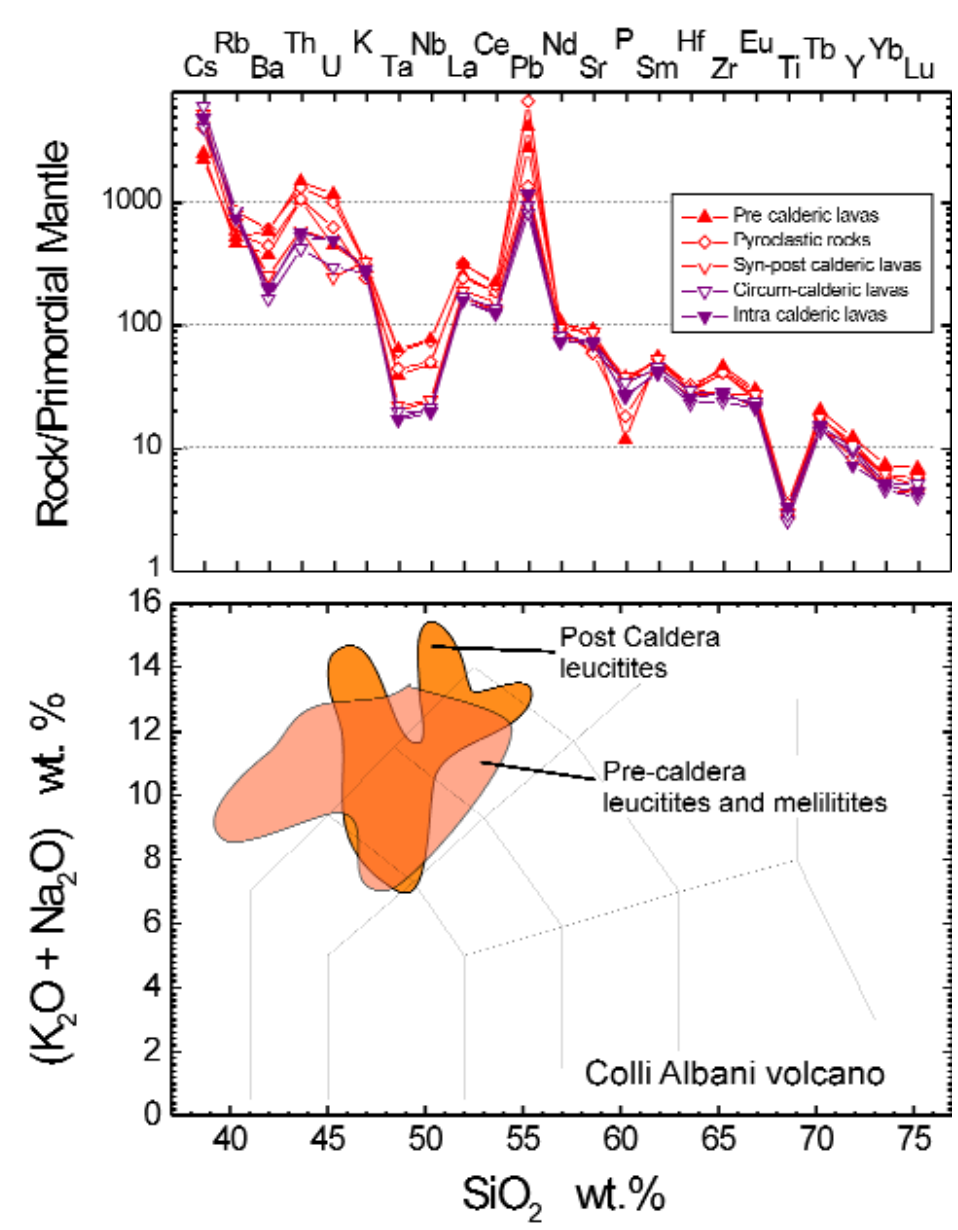
show smaller troughs at $\mathrm{Ba}$, and $\mathrm{Hf}$, with respect to post-caldera ones. In addition differences in LIL elements total abundances are also observed (Fig. 67). Boari et al. (2009a) explained these characteristics as due to a different supply of magma from a slightly different mantle source. Pre-caldera magmas should were produced by smaller degrees of partial melting of a veined metasomatised upper mantle with respect to magmas that feed the postcaldera activity of Colli Albani volcano.

\section{The Stops of the 3rd day}

The Colli Albani, at South, and the Sabatini volcanic field, at North, encircled the city of Rome in a hug of death and life. Both volcanic districts are quiescent and still show geophysical and geochemical activities and the City of Rome is built on the products generated by their paroxysmal eruptions. Historical records reports

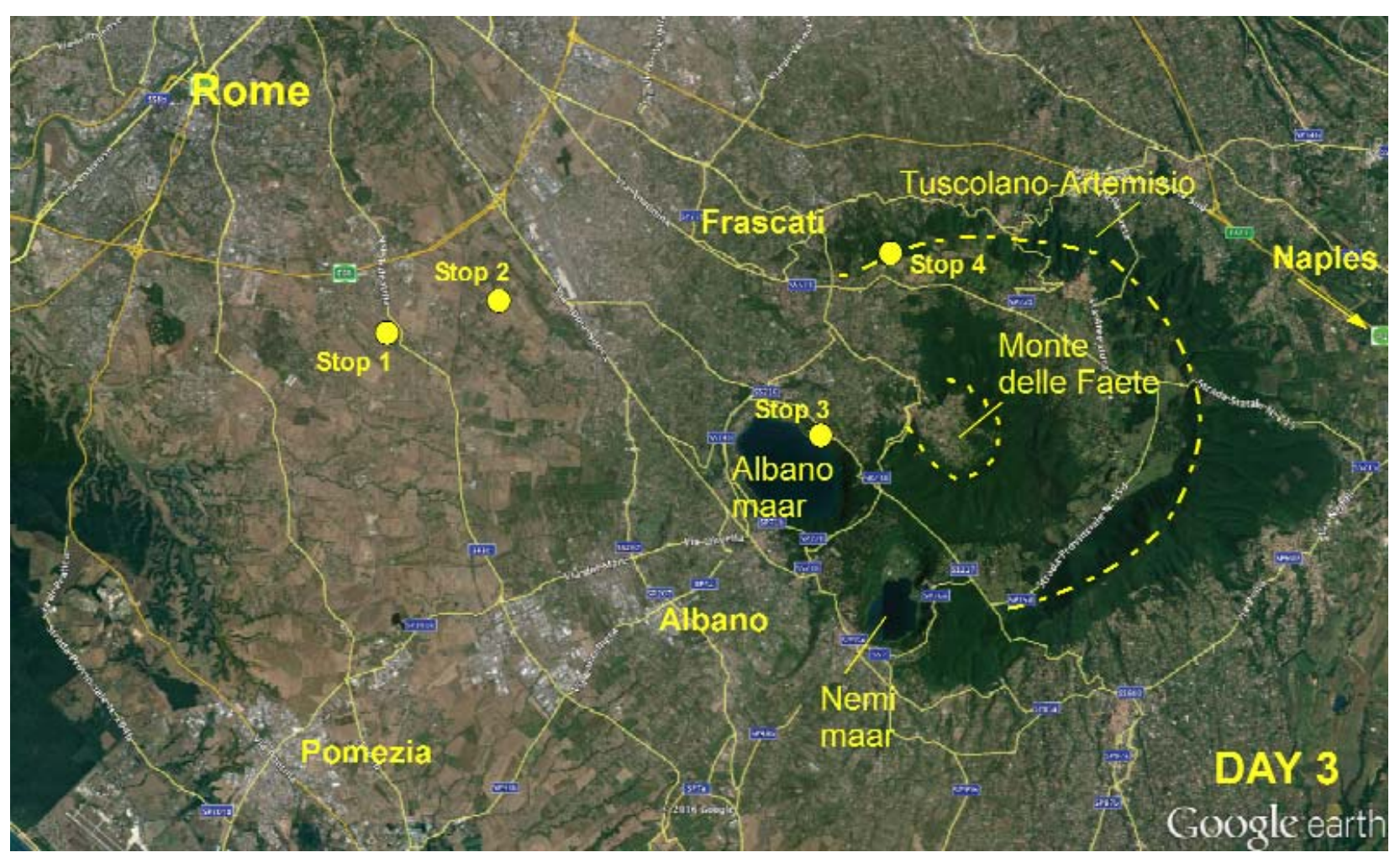

Fig. 68 - Locations of the stops of the third day at Colli Albano Volcano. Dashed line show the limit of the calderas Topographic base from "Google earth". events of death due to poisonous volcanic gas. At the same time the two volcanoes supplied to Romans fertile lands, water and building stones. Colli Albani is only few km South East of Rome, and you will drive through the A1 highway directly to Rome. In figure 68 the Stops of the day are shown.

\section{STOP 3.1: Vallerano quarry to observe the melilite-bearing pre-caldera lavas}

In the Vallerano site $\left(41^{\circ} 47^{\prime} 13^{\prime \prime} \mathrm{N}-12^{\circ} 28^{\prime} 53^{\prime \prime} \mathrm{E}\right)$, at the southern periphery of the city of Rome and in the NW sector of the Colli Albani Volcano there is an old quarry from which lavas were extracted, crushed and used to DOI: 10.3301/GFT.2017.01 
form a bed for roads or railroads. These lavas (i.e., Vallerano lavas) form a vast plateau with a volume of at least $2 \mathrm{~km}^{3}$ (De Rita et al., 1995). The main macroscopic lithofacies of the lava varies from dark to pale grey, is massive but locally vesicular, and aphyric to sub-aphyric with glassy to microcystalline groundmass enclosing rare phenocrysts of leucite (up to $7-8 \mathrm{~mm}$ in diametre) and subordinate clinopyroxene (2-3 $\mathrm{mm}$ ). In the Vallerano locality, up to 2-m-thick scoriaceous autobreccia covers the coherent facies of the lava. The maximum thickness is $30 \mathrm{~m}$, and its chemical composition is K-foiditic (Boari et al., 2009a; Conticelli et al., 2010b). Reliable age determinations suggest 460 ka (Karner et al., 2001a).

\section{STOP 3.2: the ESMAN (ex IMATER) quarry, the caldera-forming ignimbrites}

The ex IMATER quarry (Fig. 69) is located $8 \mathrm{~km}$ to the NW of the Colli Albani caldera rim and is one of the best places of to see the entire "Pozzolane Succession", which comprises the main caldera-forming ignimbrite sheets that are, from older to younger, the pozzolane rosse ignimbrite (RED), the pozzolane nere ignimbrite (PNR), and the Villa Senni eruption (VSN), which is made by two distinct flow units, the tufo lionato (VSN1, Fig. 70) and pozzolanelle ignimbrites (VSN2, Fig. 70; Giordano \& Dobran, 1994; Freda et al., 1997, 2011; Watkins et al., 2002; Vinkler et al., 2012; Giordano et al., 2006a, 2010; Funiciello \& Giordano, 2010). Ar-Ar ages are 460 ka, 407 ka and 355 ka

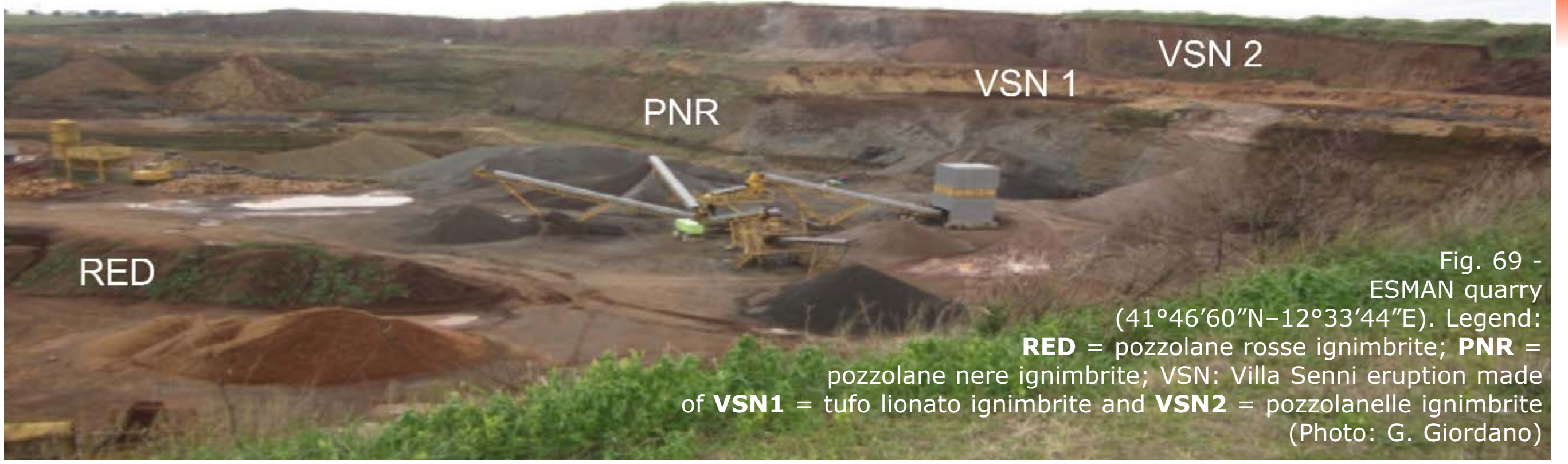




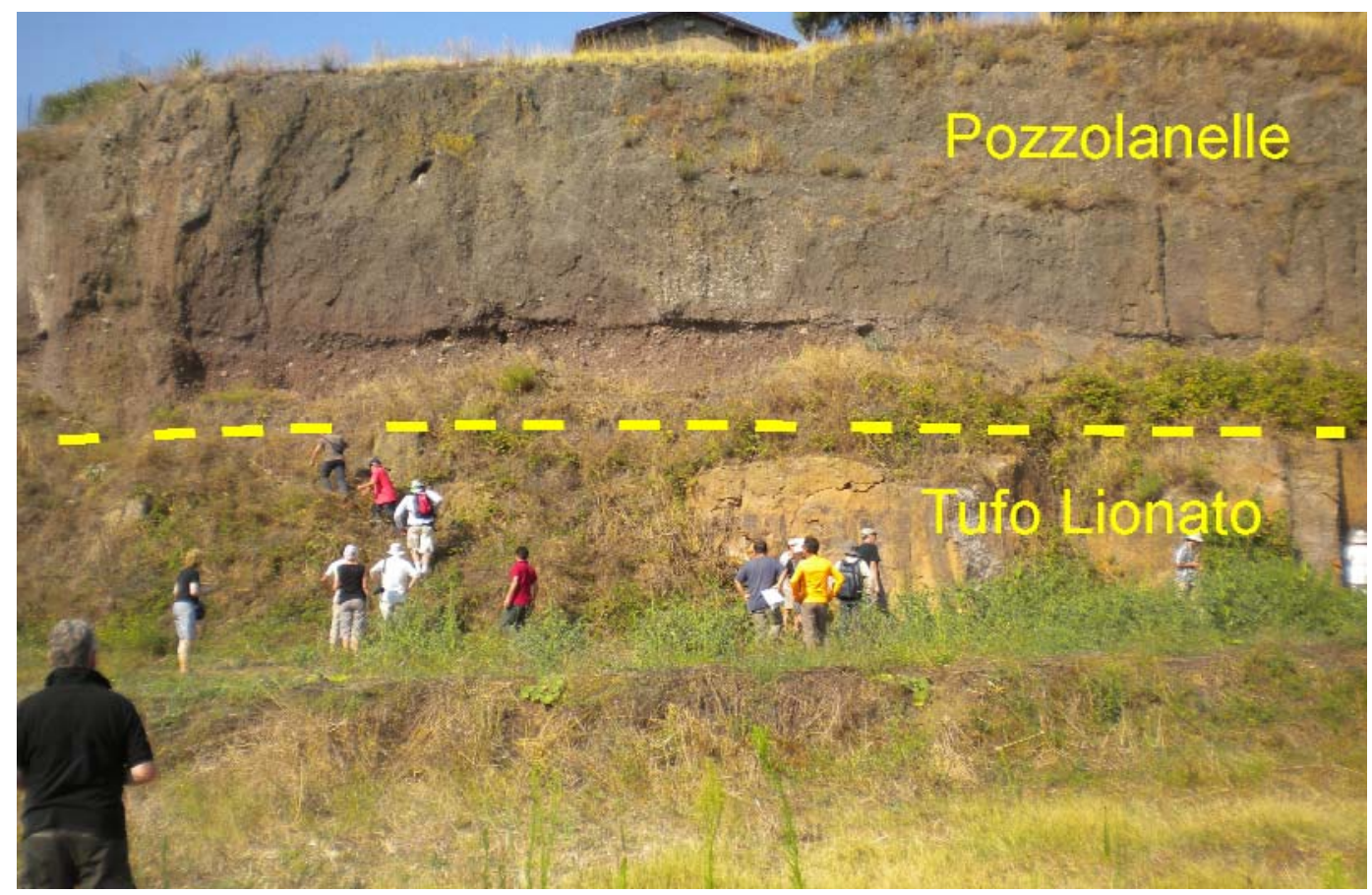

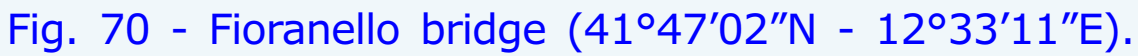
The outcrop show the contact between the bottom and top ignimbrites of the "Villa Senni" eruption: VSN1 = tufo lionato ignimbrite; VSN2 = pozzolanelle ignimbrite. Note that the pozzolanelle ignimbrite laid on its co-ignimbritic breccia.

(Photo: S. Conticelli).

respectively (Karner et al., 2001a) with an average recurrence time of ca $50 \mathrm{ka}$. D.R.E. volumes for these units are $63 \mathrm{~km}^{3}$ (RED), $15 \mathrm{~km}^{3}$ (PNR), and $28 \mathrm{~km}^{3}$ (VSN), respectively, with estimated VEI ranging between 6 and 7 (Giordano et al., 2010).

Chemical compositions range from tephrite (RED and upper VSN) to tephritic-phonolite (PNR and lower VSN) (Fig. 67), with juvenile fragments typically dark, poorly vesicular, variably porphyritic scoria and spatter clasts. These characteristics make these ignimbrites unique, and raise questions about the available models for magmatic fragmentation and extraction of large volumes of magma during caldera forming eruptions. A detailed textural study of the two main ignimbrites that form the Villa Senni eruption suggests that low-silica and lowviscosity magmas can increase their bulk viscosity during eruption due to extensive and fast microlite (dominantly leucite and pyroxene) nucleation and growth (Vinkler et al., 2012).

The "Pozzolane" units have been quarried since Roman times, providing construction material to ancient Rome and triggering one of the most important discoveries in human history, that of hydraulic cement (i.e. cement that solidifies in wet environments) made from mixing the pozzolana (grounded pyroclastic rocks or lapilli) with cement made by baked limestone powder.

\section{STOP 3.3: Albano maar succession}

At mid day you will stop on the shore of the Albano lake $\left(41^{\circ} 45^{\prime} 31^{\prime \prime} \mathrm{N}-12^{\circ} 40^{\prime} 14^{\prime \prime} \mathrm{E}\right)$ to observe the youngest centre of the monogenetic volcano, still potentially active, have lunch by the lake, and ... swimming! 
The Albano maar is the youngest centre of the Colli Albani Volcano. The crater is ellipsoidal, with the longest axis $3.5 \mathrm{~km}$ (Fig. 71). The maar is uncommon, being formed by at least seven phreatomagmatic eruptions interbedded by paleosols. The time interval spans between ca. $70 \mathrm{ka}$ and $<29 \mathrm{ka}$. Bathymetry shows its polygenetic nature, with a funnel-shaped pipe at present occupied by the deepest crater lake in Europe (ca. $170 \mathrm{~m}$ deep; Anzidei et al., 2008). The Albano phreatomagmatic succession is best exposed along the Via del

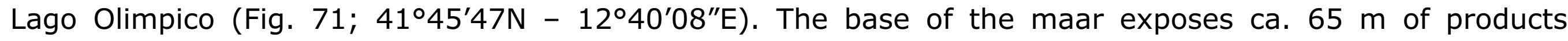
belonging to the Faete stratovolcano with alternating lava and stratified scoria lapilli beds. At places the Albano phreato-magmatic products have flowed back inside the crater reaching the present lake level (Porreca et al., 2003, 2008). The phreato-magmatic succession starts at $360 \mathrm{~m}$ a.s.l. with deposits typically alternating massive and stratified ash layers, with almost ubiquitous abundance of sedimentary (carbonates, shales), metamorphic (marbles), metasomatic (skarn) and intrusive xenoliths (De Benedetti et al., 2010), which give the typical macroscopic "salt and pepper" aspect from which these rocks, largely utilised as building stones since Roman age, obtained their local name: "peperino".

During the Holocene, Albano lake has been the site of dramatic oscillations of lake level and overflows up to Roman times (Funiciello et al., 2003, 2010; Giordano et al., 2002; De Benedetti et al., 2008). Romans dug a tunnel-outflow for the lake in 398 BC after a dramatic overflow, to regulate the lake level $70 \mathrm{~m}$ below the lowest threshold of the crater rim.

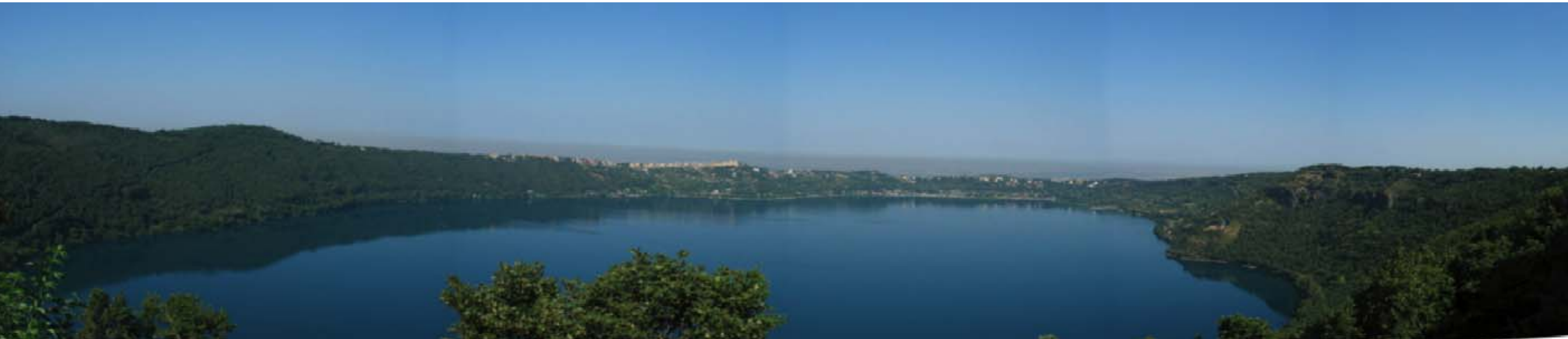

Fig. 71 - View of the Albano maar, from the road that the crater rim (Photo: G. Giordano). 


\section{STOP 3.4: Tuscolo rim and the caldera}

West of Frascati village you will reach the edge of the caldera $\left(41^{\circ} 48^{\prime} 17^{\prime \prime} \mathrm{N}-12^{\circ} 42^{\prime} 04^{\prime \prime} \mathrm{E}\right)$ overviewing the inner portion of the caldera with its intracaldera stratovolcano: the Monte Faete (Fig. 72). In addition it is possible to observe the structural control of the ring fault system on the caldera colapse and the proximal outcrops of the ignimbrites of the "Villa Senni" eruption.
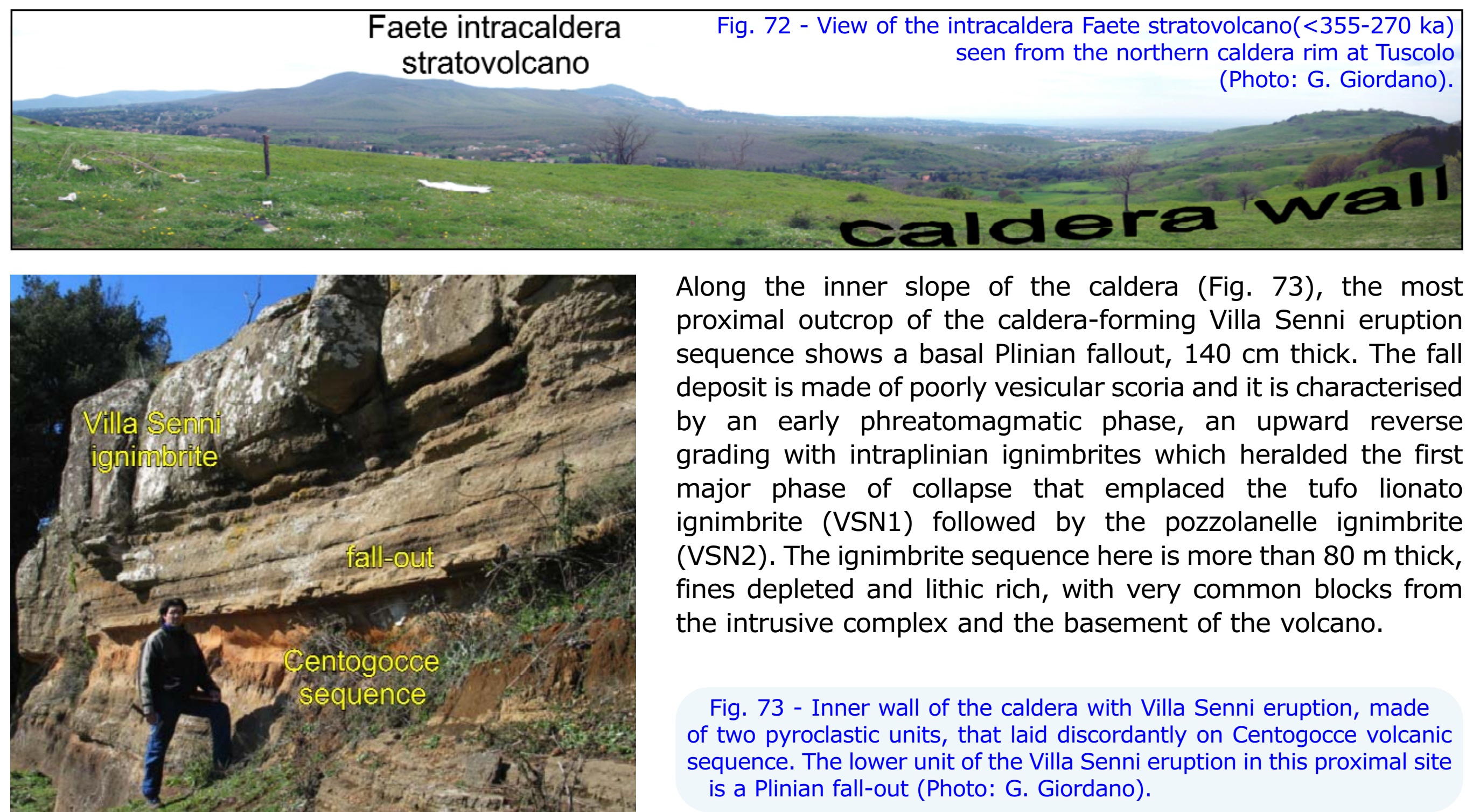

Along the inner slope of the caldera (Fig. 73), the most proximal outcrop of the caldera-forming Villa Senni eruption sequence shows a basal Plinian fallout, $140 \mathrm{~cm}$ thick. The fall deposit is made of poorly vesicular scoria and it is characterised by an early phreatomagmatic phase, an upward reverse grading with intraplinian ignimbrites which heralded the first major phase of collapse that emplaced the tufo lionato ignimbrite (VSN1) followed by the pozzolanelle ignimbrite (VSN2). The ignimbrite sequence here is more than $80 \mathrm{~m}$ thick, fines depleted and lithic rich, with very common blocks from the intrusive complex and the basement of the volcano.

Fig. 73 - Inner wall of the caldera with Villa Senni eruption, made of two pyroclastic units, that laid discordantly on Centogocce volcanic sequence. The lower unit of the Villa Senni eruption in this proximal site is a Plinian fall-out (Photo: G. Giordano). 


\section{Day 4: Cimino and Vico nested volcanoes}

On the basis of morphological, geological, and mineralogical data the Monte Cimino and Vico volcanoes (Fig. 74) represent two distincts edifices active in different times but fed by the same plumbing system (e.g., Sabatini, 1912; Perini, 1997; Perini et al., 1997, 2000, 2003, 2004; Conticelli et al., 2010a, 2013, 2015a; Peccerillo, 2005a). According to Peccerillo et al. (1987) the Monte Cimino volcanic complex, active during the Early Pleistocene, belongs to the Tuscan Magmatic Province (see next paragraph on the fifth day) whilst the nested and younger Vico stratovolcano, active during the Late Pleistocene, belongs to the Roman Magmatic Province (Fig. 74).

The Cimino volcanic complex is the older edifice of the Cimino-Vico area, with an evolution through four main phases (Conticelli et al., 2013) occurred in a short time span from $1.35 \pm 0.08$ to $0.94 \pm 0.20$ Ma (e.g., Evernden \& Curtiss, 1965; Nicoletti, 1969; Borghetti et al., 1981; LaBerge, personal communication; Fig. 74c).

The Cimino Volcano is made up by: i) an initial alignment of trachydacitic to trachytic cryptodomes along a NW-SE trend (autoct. "peperino delle alture"), parallel to the horst and graben structures that furrow the Italian peninsula in the region between the Apennine chain and the Tyrrhenian shoreline (Fig. 53); ii) two welded pyroclastic flow units, produced probably when the activity concentrated in the central part of the original (autoct. "peperino tipico"); iii) lava flows of the Monte Cimino cone; iv) final mafic lava flows unit (Fig. 75; e.g., Mittempergher \& Tedesco, 1963; Mattias \& Ventriglia, 1970; Micheluccini et al., 1971; Puxeddu, 1971; Lardini \& Nappi, 1987; Perini et al., 2003; Cimarelli \& De Rita, 2006a, b; LaBerge et al., 2006, 2008; Conticelli et al., 2013).

After a hiatus of some hundreds of thousands of years, renewal of volcanic activity occurred in the area at 450 ka few kms to the southwest of the Monte Cimino. The Vico volcanic district belongs to the Roman Magmatic Province (e.g., Washington, 1906; Conticelli et al., 2004, 2010a; Avanzinelli et al., 2009) and consists of a single Pleistocene volcanic edifice built in the form of a conic stratovolcano cut by a summit polygenetic caldera (Mattias \& Ventriglia, 1970; Perini et al., 1997, 2004). Post-caldera activity, subordinate in volume, occurred both within and on the edge of the caldera (Fig. 74B; Perini et al., 1997, 2004). The Vico Volcano developed within the NW-SE 

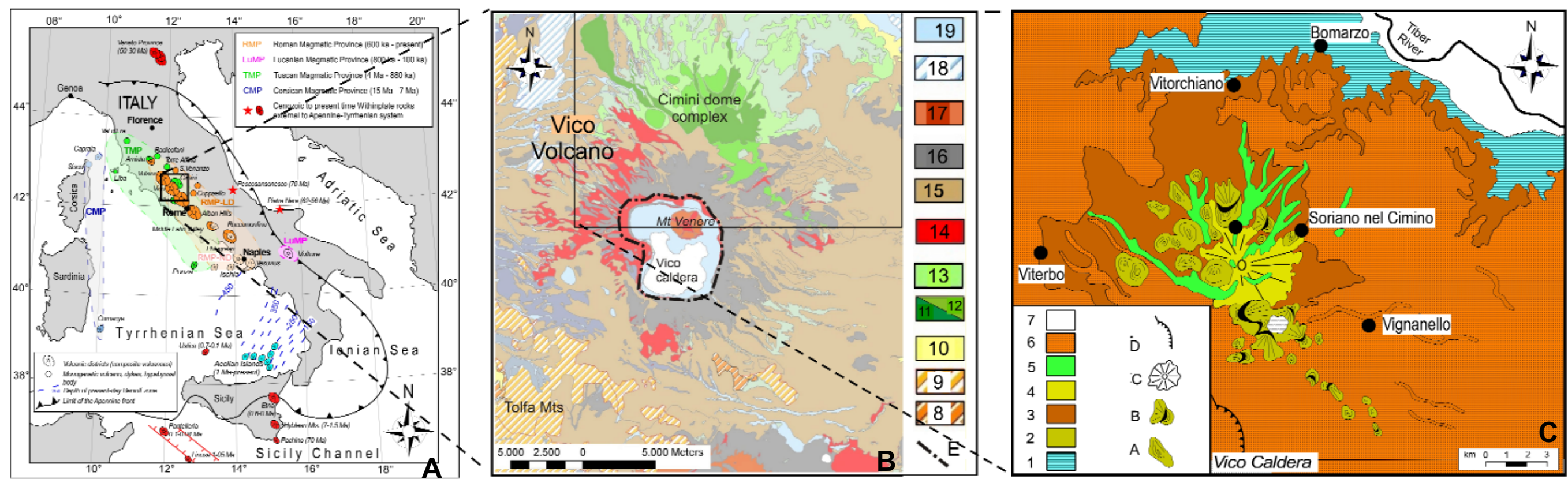

Fig. 74 - A) sketch map of the distribution of the Italian volcanism with framed the Cimini and Vico nested volcanoes; B) geological sketch map of the Vico Volcano (Roman Province) with framed the area blow up in C; C) geological sketch map of Monte Cimino Volcanic complex (Tuscan Province).

Legend C: 1) sedimentary substratum; 2) domes and lava flows of the Ist Cimino phase; 3) pyroclastic flows of IInd Cimino phase; 4) latitic to trachitic lava flows of the IIIrd Cimino phase; 5) olivine latitic to shoshonitic lava flows of the IVth Cimino phase; 6) leucitebearing Vico volcanic rocks (Roman Province); 7) Quaternary fluvial deposits. Legend B: 8) Macigno flysch; 9) allochtonous flysch; 10) Pliocene-Pleistocene marine sediments; 11) Cimino final lavas; 12) latitic to trachytic Cimino domes; 13) trachydacitic Cimino ignimbrite; 14) tephrite to leucitite Vico lavas; 15) trachyphonolitic Vico ignimbrites; 16) "Carbognano" phreatomagmatic ignimbrite; 17) post caldera scoria cones and lavas; 18) travertine; 19) Holocene alluvial and lacustrine deposits. (redrawn after Perini, 1997;

Perini et al., 1997, 2004; Conticelli et al., 2007, 2010a; 2013, 2015a).

Siena-Radicofani and Paglia-Tevere extensional basin (Barberi et al., 1994), and it almost covers completely the older Monte Cimino volcanic complex sharing with it the deep plumbing system and some shallow level magmatic reservoirs, as testified by the interaction between silica-saturated and -undersaturated magmas of the Vico proto-volcano (e.g., Rio-Ferriera phase; Perini, 1997; Perini et al., 1997, 2000, 2003, 2004). 


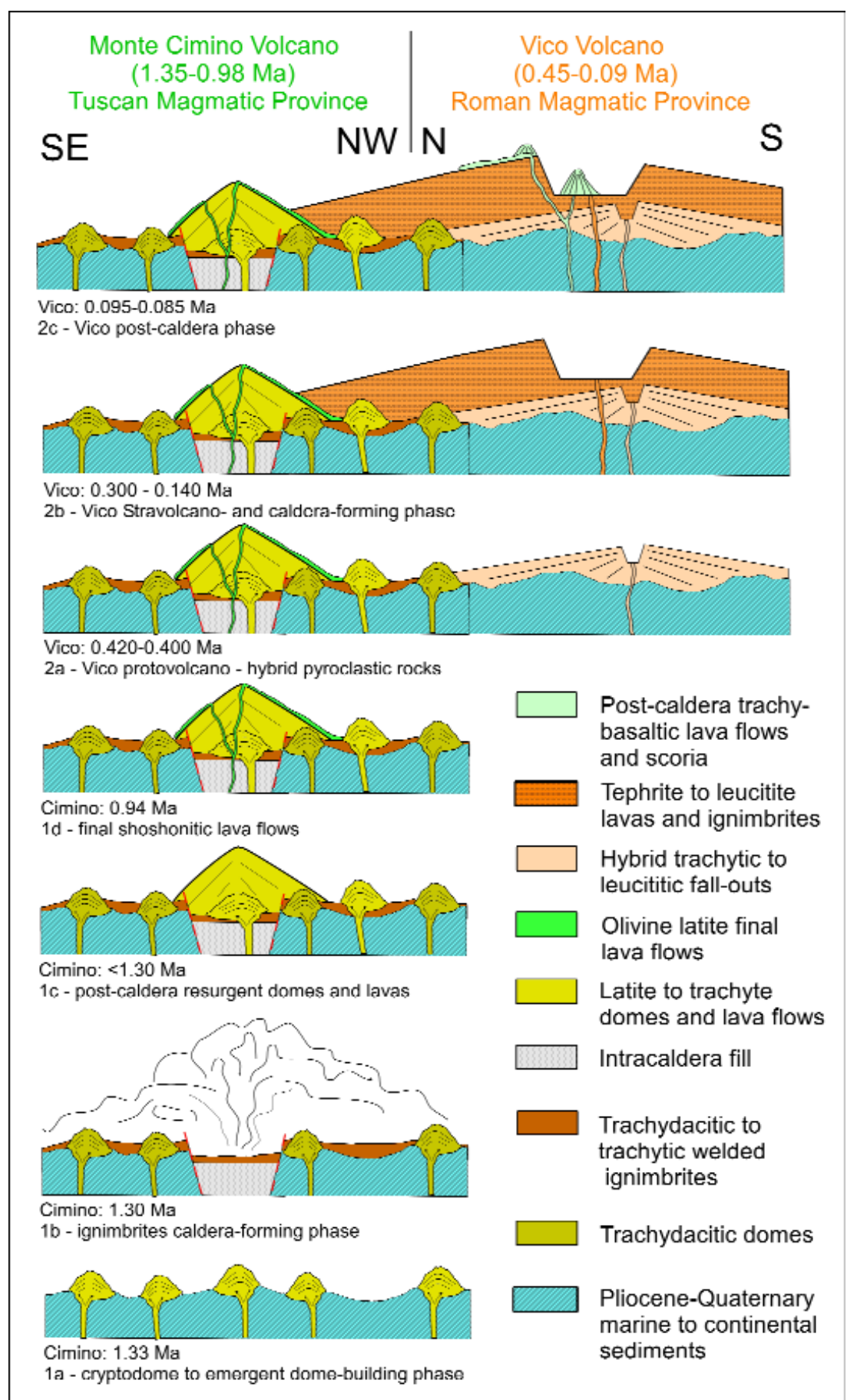

The activity of Vico Volcano is divided into three main phases (Fig. 75): the Rio Ferriera, the Lago di Vico, and the Monte Venere phases (Perini et al., 1997, 2004). The early activity, during the Rio Ferriera phase (1st), produced pyroclastic fall-out with subordinate pyroclastic flow units and lavas (Cioni et al., 1987; Barberi et al., 1994; Perini et al., 1997, 2000). The begin of this phase is marked by the emplacement of the basal Plinian fall-out at about $420 \mathrm{ka}$, and later lavas and pyroclastic fall at about 400 ka (Sollevanti, 1983; Barberi et al., 1994). All K/Ar model ages older than 420 ka (Nicoletti, 1969) are clearly biased.

Fig. 75 - Geological sketch section through the Monte Cimino (1.3-0.9 $\mathrm{Ma})$ and Vico (0.45-0.05 Ma) nested volcanoes. Monte Cimino Volcano: the 1 st phase of activity was characterised by the emplacement of trachytic to trachydacitic lava domes along a NW-SE alignment and of two ignimbrite units. Highly polymerisation and gas contents of magmas brought some domes to outburst; the $2^{\text {nd }}$ phase was characterised by the emission of lava flows from the Monte Cimino centre, accumulating in the form of an exogenous large cone made by coalescent domes and massive lavas with latitic to trachytic compositions; the 3rd phase was characterised by outpouring, from the top and fractures along the flanks of the Monte Cimino cone, of low viscosity mafic lavas (Conticelli et al., 2013). Vico stratovolcano: the 1st phase of activity (Rio Ferriera) built up a flat protovolcano characterised by a volcanic sequence made up by pyroclastic fallout units and minor lavas with increasing leucite and decreasing sanidine content upsection; the 2nd phase (Lago di Vico) was characterised by the built up of the main volcanic edifice through the piling up of leucite-bearing lava flows, and successively by the formation of the polygenetic apical caldera through four large ignimbritic eruptions; The 3rd and post-caldera phase (Monte Venere) was characterised by a strong reduction of volumes of magma erupted, to form intra- and peri-caldera cinder cones and lava flows mainly with a leucite-free shoshonitic composition (redrawn after Conticelli et al., 2013). 
The Lago di Vico phase (2nd) was initially characterised by the eruptions of abundant lava flows and subordinate pyroclastc products (300-260 ka; Sollevanti, 1983; Laurenzi \& Villa, 1987; Barberi et al., 1994). Voluminous leucitebearing lava flows were emplaced ( 50 km3; Bertagnini \& Sbrana, 1986; Perini et al., 1997, 2004). Villemant \& Fléhoc (1989) reported a K/Ar age of $180 \mathrm{ka}$ and a U-Th isochron age of $210 \mathrm{ka}$ for the final episode of the stratovolcano-building period. The late period of the Lago di Vico phase was characterised by four ignimbrite-forming paroxysmal eruptions each of them followed by a calderic collapse resulting in the $8 \mathrm{~km}$ wide polygenetic Vico caldera with its typical asymmetric morphology (Figs 74B, 76)(Perini et al., 1997, 2004). The four eruptions brought to the emplacement of the "Farine", "Ronciglione" (160 ka), "Sutri" (autoct. "tufo rosso a scorie nere", $150 \mathrm{ka}$ ) and "Carbognano" (140 ka) ignimbrites (e.g., Sollevanti, 1983; Laurenzi \& Villa, 1987; Barberi et al., 1994; Perini, 1997; Perini et al., 1997, 2004; Bear et al., 2009a, b).

The Monte Venere phase ( 3 rd $)$ took place after the polygenetic summit caldera reached the present day shape and morphology (Fig. 76), and comprises the undated "tufi finali" formation, several monogenetic cinder cones and few lava flows. The Monte Venere itself is an intra-caldera cinder cone that rose from the caldera bottom almost as high as the caldera walls. Three other cinder cones are found along the northern caldera rim from Poggio Nibbio to Poggio Varo (Fig. 74B) and from a fracture between these two cinder cones a small shoshonitic lava flow was vented and it flowed down both into the caldera and the external flank of the volcano (Perini et al., 1997, 2004). K/Ar dating of Monte Venere s.s. rocks yield ages between 95 and 85 ka (Laurenzi
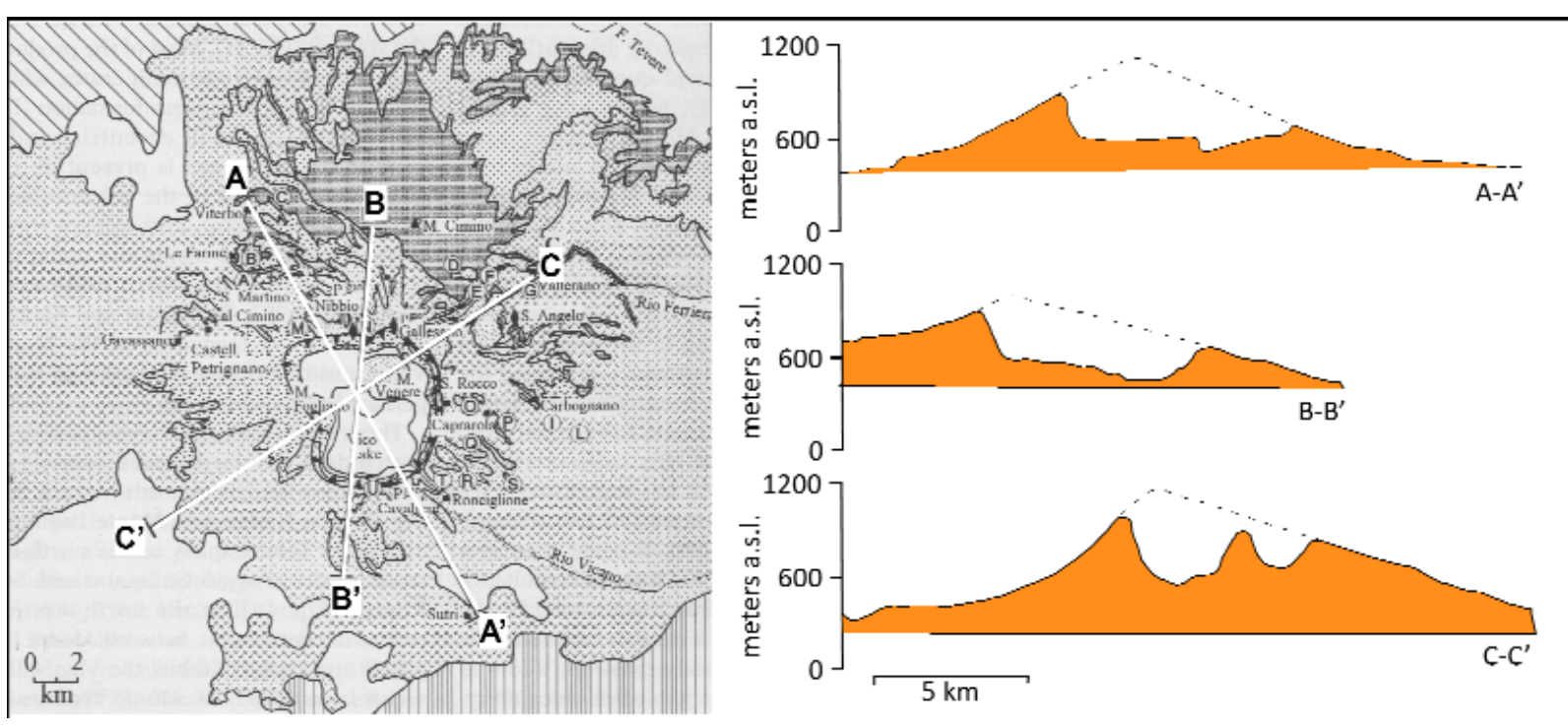

\& Villa, 1985; Villemant \& Fléhoc, 1989); a $40 \mathrm{Ar}-39 \mathrm{Ar}$ age, equal within error to the $\mathrm{K} / \mathrm{Ar}$ ones, was obtained for scoriaceous deposits found in a drill from the Vico lake sediments (Magri \& Sadori, 1999; Laurenzi, unpublished data).

Fig. 76 - Left: Geological sketch map of the Vico volcano with reported the tracks of each topographic profile. Right: Profiles of Vico Volcano caldera with interpretation of the original morphology of the stratovolcano prior to caldera collapses after ignimbrite eruptions. 
Composition of volcanic rocks of Cimino and Vico volcanoes

Monte Cimino volcanic rocks are invariably leucite-free ranging with time from trachydacite (1a), to trachyte (1a), latite (1b), olivine-latite (1c) and shoshonites (1d), with interstitial glasses of ignimbrites and trachydacitic early domes ranging in composition from rhyolite to trachydacite (Fig. 77). Sanidine megacrysts are frequently found in the trachydacite, trachytes and latites, whilst in olivine-latites large sanidine is clearly a xenocryst in isotopic disequilibrium with the bulk (Perini et al., 2003). Shoshonite and olivine latites have sub-aphyric to slightly porphyritic textures with euhedral to skeleton olivine phenocrysts set in a groundmass made of sanidine, clinopyroxene, plagioclase, opaques and accessory apatite and phlogopite. Latite, trachyte, and trachydacite have strongly porphyritic textures with euhedral sanidine megacrysts, and plagioclase,

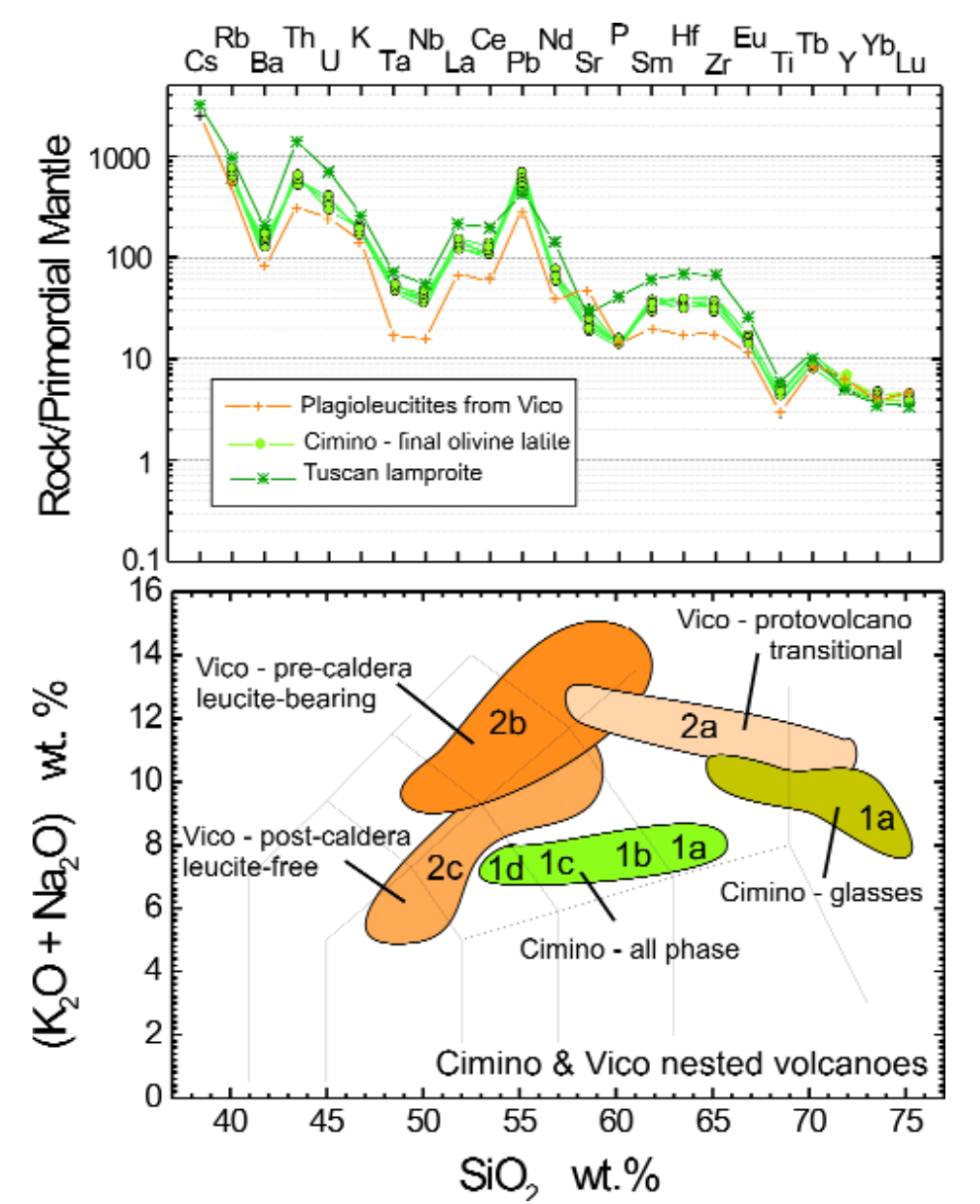
orthopyroxene, biotite, sanidine and clinopyroxene phenocrysts. Microphenocrysts of plagioclase, orthopyroxene, biotite, ilmenite, apatite and zircon, together with variably amount of glass, form the groundmass of these rocks (Conticelli et al., 2013).

The pyroclastic rocks and lavas of the first phase of Vico Volcano (Rio Ferriera sequence) have a mild potassic nature. They range in composition from phonolite to trachyte, trachydacite and rhyodacite (Fig. 77). Large sanidine phenocrysts are also found, but they are not in equilibrium with Vico magmas, corroborating the hypothesis that Rio Ferriera formations represent hybrid rocks due to magma mixing between Cimino magmas that stagnated at shallow depth and newly arrived ultrapotassic silica-undersaturated leucite-bearing Roman magmas (Perini et al., 2000, 2003). The second period of activity (Lago di Vico sequence) was dominated by plagioclase-leucititic lava

Fig. 77 - Bottom: classification diagram for rocks of the Monte Cimino volcanic complex and of the Vico stratovolcano (TAS after Le Maitre et al., 2002). Top: spiderdiagram for incompatible trace elements normalised to primordial mantle values (Sun \& McDonough, 1990). Torre Alfina lamproite is reported for comparison. (Source of data: Conticelli, 1998; Conticelli et al., 2002, 2007, 2013; Gasperini et al., 2002; Perini et al., 2003). Cimino glasses are EPMA analyses of interstitial glass from Monte Cimino volcanic rocks of first two phases of activity. 
flows and pyroclastic rocks, ranging in compositions from leucite-bearing phonolitic tephrite to leucite-bearing phonolite, passing through tephritic-phonolite (Fig. 77). Alkali and especially potassium loss after syndepositional leucite and glass transformation in pyroclastic rocks is observed also at Vico Volcano, similarly to what observed for other rocks of the Roman Province. The post caldera activity (Monte Venere sequence) shows a clear bimodal petrologic affinity. Leucite-bearing tephrite are found in the Monte Venere scoria and lavas, whilst leucite-free olivine latite (Poggio Nibbio lavas) and olivine trachybasalts (Poggio Nibbio scoria) are erupted along the northern rim of the caldera (Fig. 77; Perini et al., 1997, 2004).

Incompatible trace element, normalised to primordial mantle, of Cimino and Vico rocks shows similar HFSE to LILE fractionation, although small differences are observed at $\mathrm{Sr}, \mathrm{Ta}, \mathrm{Hf}, \mathrm{Sm}$ and $\mathrm{Zr}$, with deep troughs at $\mathrm{Ta}, \mathrm{Nb}$, and $\mathrm{Ti}$, and peaks at $\mathrm{Th}$ and $\mathrm{Pb}$ (Fig. 77). These patterns closely resemble subduction-derived calc-alkaline igneous rocks (Peccerillo 1985; Conticelli \& Peccerillo, 1992; Perini et al., 2000, 2004; Conticelli et al., 2007, 2013).

\section{Stops of the morning of the 4th day}

You will reach the Cimino and Vico clustered volcanoes from Orte, where you will leave the A1 paytoll freeway from Rome, driving along the SS675 highway. Immediately left Orte the highway rise to the top of a plateau made of the pyroclastic flows of the two volcanoes. Sometimes travertine rocks are visible along the highway while driving to Viterbo. You will leave the SS675 highway at the Vitorchiano, you turn left on the SP25 in the direction of Soriano al Cimino leaving Vitorchiano village behind.

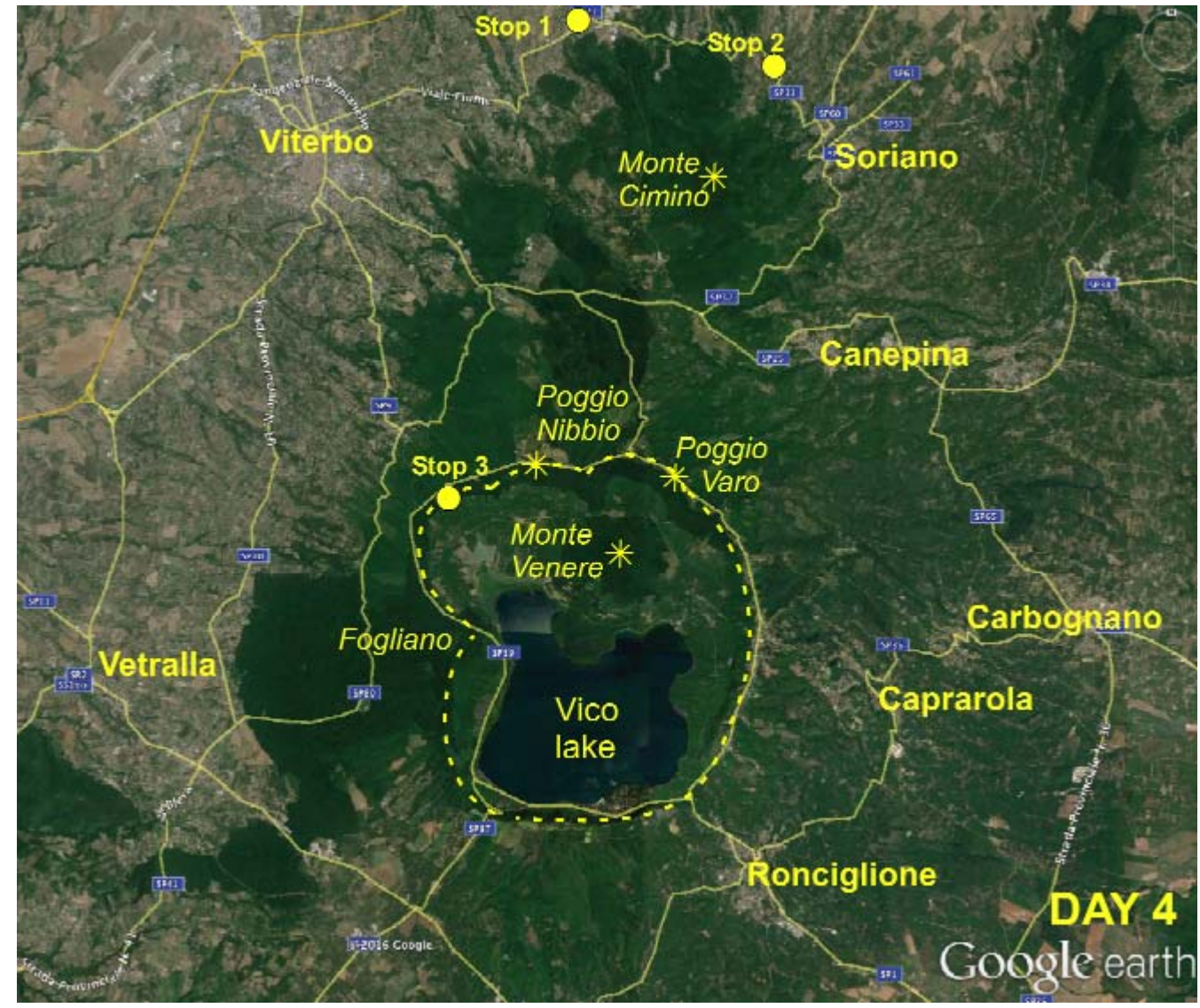

Fig. 78 - Locations of the Stops of the morning of the forth day at the Cimino and Vico nested volcanoes. Dashed line show the limit of the calderas. Topographic basemap from "Google earth". 
Once reached the quarry $\left(42^{\circ} 26^{\prime} 58^{\prime \prime} \mathrm{N}-12^{\circ} 10^{\prime} 02^{\prime \prime} \mathrm{E}\right)$, just before to walk down the excavated area you will stop to look at the Monte Cimino Volcano and its domes (Fig. 79). It is possible to see the highest point of the Monte Cimino volcanic complex represented by the "Faggeta" of Monte Cimino, a 1070 m. (a.s.l.) high volcanic edifice made by a large dome and several lava flows belonging to the third and fourth phases of Cimino activity. The smaller Ciliano, Roccaltia, and Moltanto domes are also visible, although some of them are clearly asymmetric due to lateral collapse (Fig. 79).

Then you will get into the peperino quarry to observe the quarrying procedure of the welded ignimbrite used as building stone.

The peperino ignimbrite (autoc. "peperino tipico", Mittempergher \& Tedesco, 1963) is a welded ignimbrite made of two distinct pyroclastic flow units produced by different eruptions (Lardini \& Nappi, 1987). Both flow units are strongly welded and made up a large plateau on which most of the villages of the area, such as Vitorchiano, are built on (Fig. 80). The relationships of "peperino ignimbrites" with the domes of the "peperino delle Alture" are still matter of debate. Recently LaBerge et al. (2008) described the flow patterns of the "peperino tipico" ignimbrite through anisotropy of magnetic susceptibility of both flow units, but did not clarify the stratigraphyc sequence within the dome complex. LaBerge et al. (2006) described the stratigraphic

Fig. 79 - View from North of the Monte Cimino Volcano, with in front of it, with smaller sizes and heights are visible from East to West the Ciliano, Roccaltia, and Montalto lava domes (Photo: S. Conticelli).

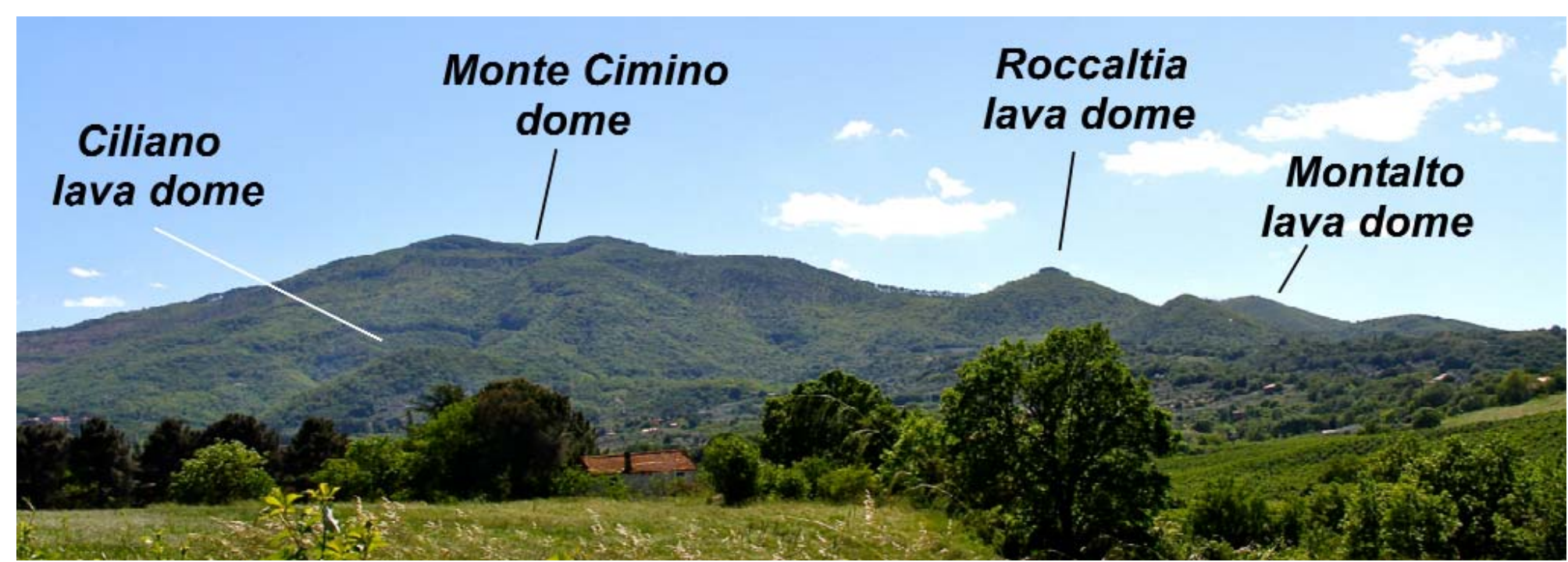


boundary between the sedimentary substratrum and the "peperino tipico" ignimbrite as a primary feature generated by syn-depositional shear. Cimarelli \& De Rita (2006a) on the base of morphological data inferred that the Cimino dome complex is a shallow level laccolith and in some places preceded the "peperino tipico" ignimbrites.

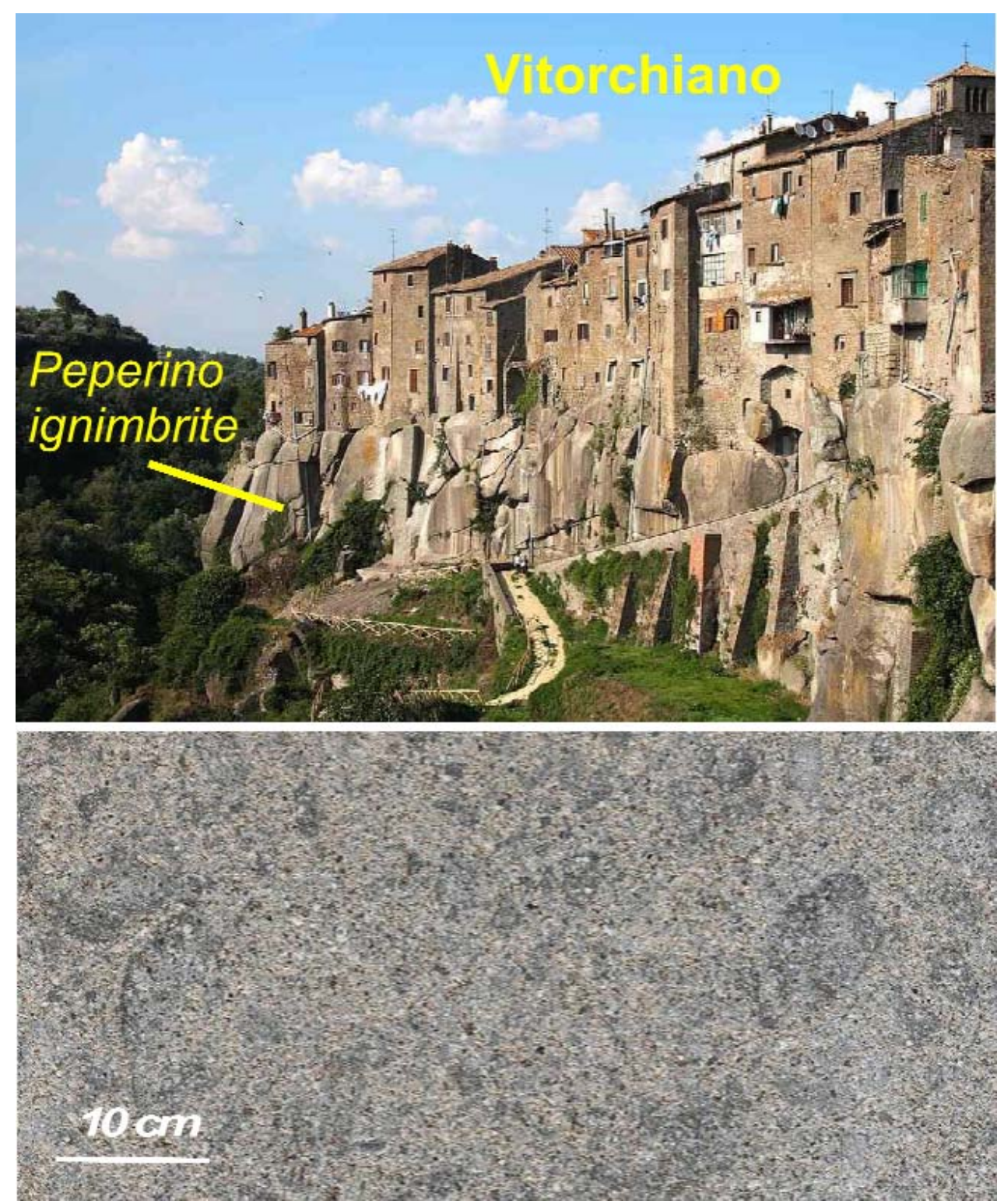

The "peperino ignimbrite", which takes its name from the salt and pepper appearance, is a crystal-rich and matrix-poor, welded ignimbrite characterised by the occurrence of flattened, vesicle-free, juvenile fragments called "fiamme". A red and a grey varieties do occurs, although it is not clear whether they are a lateral variation of a single flow or the colour dicriminate between different flow units (Lardini \& Nappi, 1987). In the bottom of figure 80 it is shown a raw section parallel to horizontal depositional surface of the grey coloured ignimbrite. The rocks have trachytic to trachydacitic composition with crystal fragments of biotite, plagioclase, sanidine, clinopyroxene and orthopyroxene set within sferulitic glass. Microphenocrysts of plagioclase, orthopyroxene, biotite, ilmenite, apatite, and zircon are also found (Conticelli et al., 2013). Orthopyroxene from juvenile fragments is dotted by abundant inclusions of glass, zircon and apatite.

Fig. 80 - Top: Cliff of the peperino ignimbrite that made the plateau on which the Vitorchiano village was built. Note that houses were built with the same stone of substratum. Bottom: Raw section of the "peperino" grey ignimbrite. Note that fiamme in this case are not flattened because the cut for quarrying is usually made parallel to the horizontal surface (Photo: S. Conticelli). 
Taking the SP31 road to Soriano nel Cimino from Pallone junction you will stop along the road, at the big turn at Santa Lucia site, to observe one of the several final olivine-latititic lavas. The Santa Lucia lava flow was vented from a fracture on the northern flank of Monte Cimino edifice. The final lavas are mafic lamproite-like ultrapotassic rocks (Conticelli et al., 2013), similar in composition to other Tuscan lamproite-like rocks such as that from Torre Alfina (Fig. 104). The Santa Lucia lava is one of the best example of the final lavas with phenocrysts of euhedral olivine and rare xenocrysts of sanidine and plagioclase (Fig. 81).

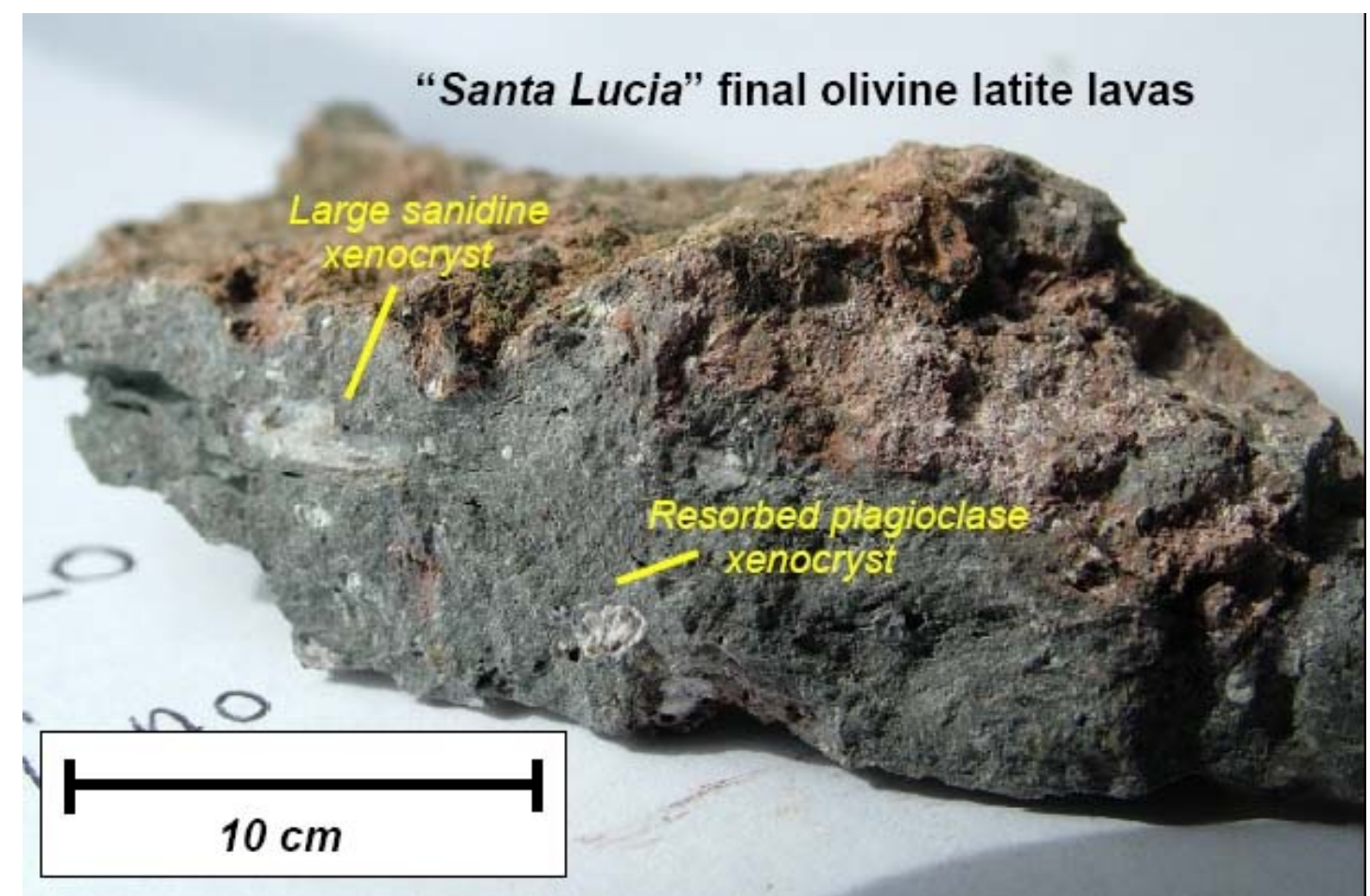

Fig. 81 - Hand speciment of Santa Lucia lava (Photo:

L. Campbell courtesy).

STOP 4.3: Vico Caldera rim $\left(42^{\circ} 21^{\prime} 31^{\prime \prime} \mathrm{N}-\right.$ $\left.12^{\circ} 08^{\prime} 31^{\prime \prime} \mathrm{E}\right)$

The leucite-bearing tephritic lavas of the conebuilding phase of the Vico stratovolcano (Lago di Vico sequence) outcrop along the wall of the caldera. Plagio-leucitites differ from lamproic rocks for the lower silica activity of the magmas, and thus of their degree of silica saturation (Fig. 76). Here you can observe typical fresh lavas with large phenocrysts of leucite and small microlites of diopsidic clinopyroxene and plagioclase (Fig. 84).

From the rim you can have a magnificient view of the Vico polygenetic caldera (Fig. 82), generated by several Plinian eruptions producing the four large ignimbrites that are interlayered with lavas at the end of the conebuilding phase. Inside the caldera is a volcanic lake, which is partially replaced by a post-caldera cinder cone, the Monte Venere cone (Fig. 83). The post caldera activity at Vico is leucite-free with a shoshonitic affinity. 


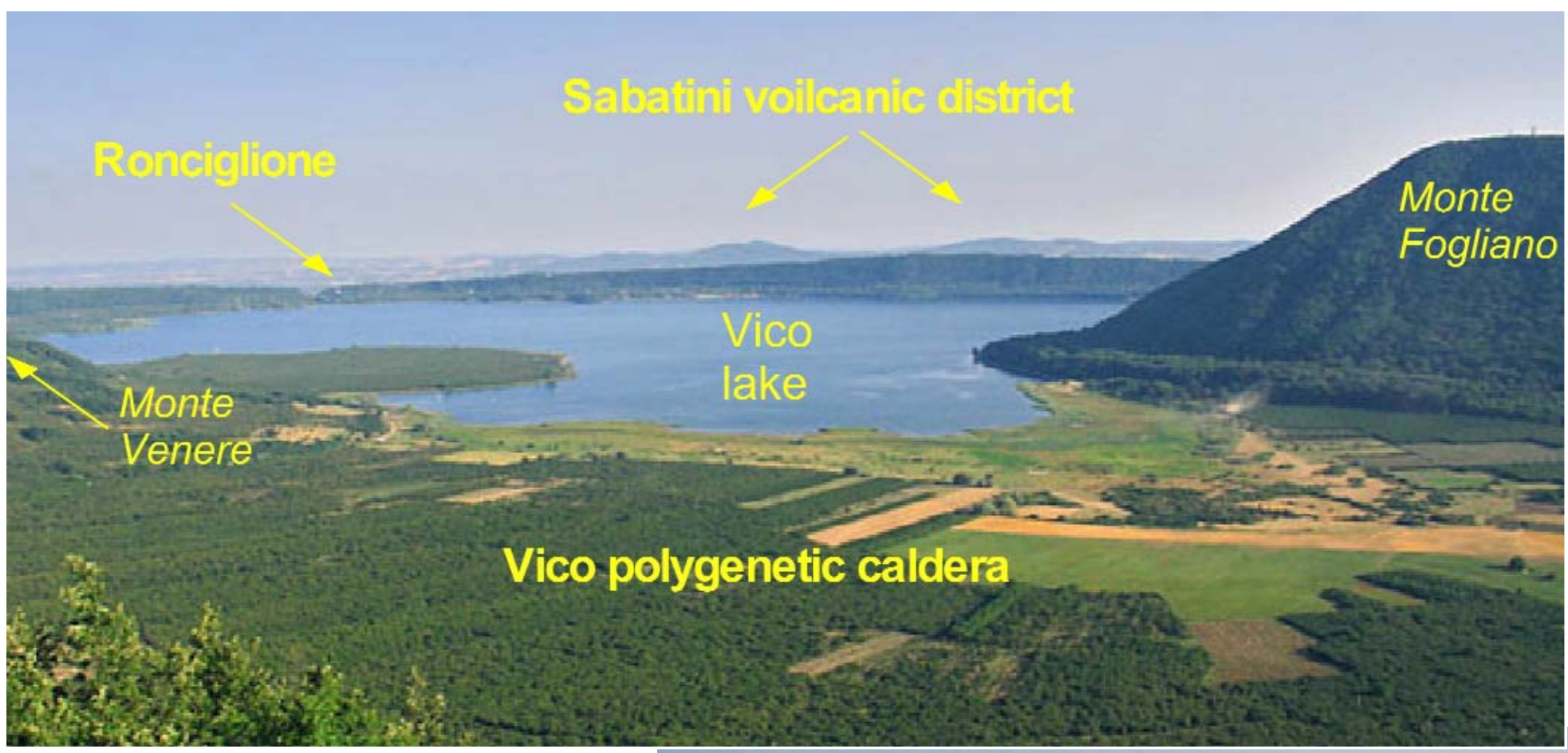

Fig. 82 - View of the Northwestern sector of the Vico caldera an lake from its Northern rim (Photo: G. Perini courtesy).

Fig. 83 - View from the lake of the Monte Venere intra-caldera cone (Photo: G. Perini courtesy).

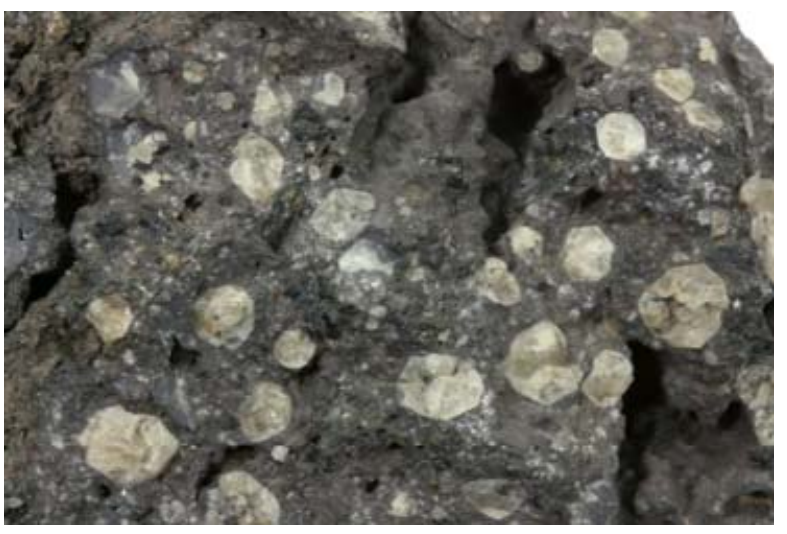

Fig. 84 - Hand-specimen of sample VCO 99 phonolitic tephrite (Photo: G. Perini courtesy).

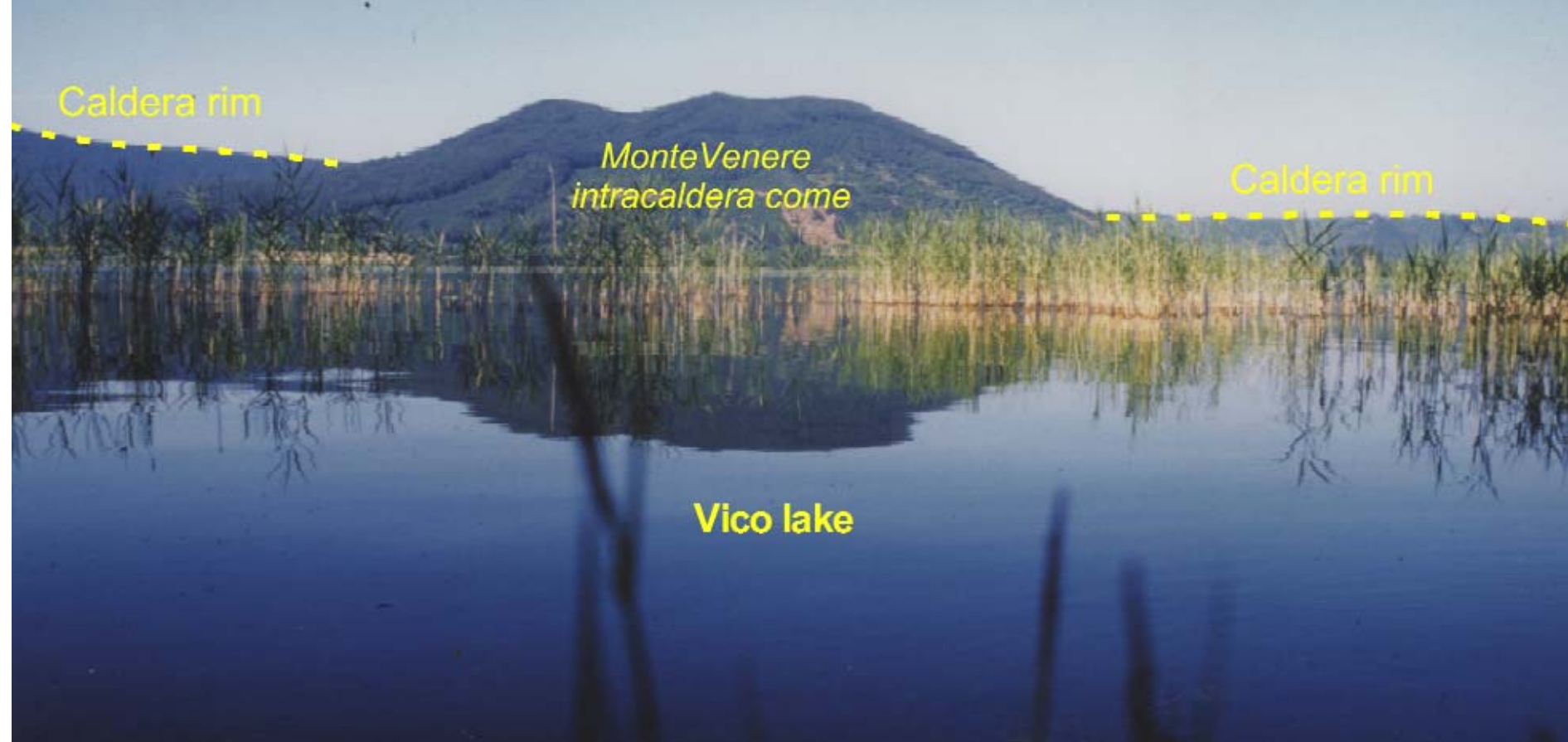




\section{Day 4 (continue): the Vulsini district}

The Vulsini district is the northernmost volcanic cluster of the Roman Province, if the hybrid volcano of Monte Amiata is not considered (Conticelli et al., 2015b). The Vulsini district is made up by the coalescence of five large volcanic edifices (inset of Fig. 85): palaeo-Bolsena, Bolsena, South Vulsini Plateau, Montefiascone and Latera volcanoes (Nappi et al., 1987, 1998; Palladino et al., 2010). The vulsinian volcanic rocks cover an area larger than $2,000 \mathrm{~km}^{2}$, filling up a depression represented by the southern continuation of the Siena-Radicofani and Paglia-Tevere grabens. The coalescence of the five volcanic edifices formed a shield-like structure with a central depressed zone nowadays occupied by the Bolsena lake (Fig. 85). Four of the five vulsinian volcanoes, are made of pyroclastic rocks with minor lavas (Fig. 86). A lava plateau is extensively found in the southern sector of the district and in the early history of the Latera Volcano (e.g., Conticelli et al., 1986, 1987; Vezzoli et al., 1987).

The palaeo-Bolsena volcanic edifice is the oldest volcanic center of the Vulsinian volcanic district and it is made up by the large trachytic, partly welded, ignimbrite called "nenfro", leucititic to tephrite-phonolitic lava flows and Plinian pyroclastic fall horizons (Nappi et al., 1987, 1991, 1994, 1995). Volcanic activity began with a Plinian fall layer dated at $590 \mathrm{ka}$ (40Ar-39Ar, Barberi et al., 1994) and 0.58 Ma (K/Ar, Nappi et al., 1995). Several conflicting ages are reported for the "nenfro" ignimbrite, which likely caused the palaeo-Bolsena early calderic collapse, were published: $880 \mathrm{ka}$ (K/Ar, Nicoletti et al., 1981a, b), $500 \mathrm{ka}$ (40Ar-39Ar, Barberi et al., 1994) and $510 \mathrm{ka}$ (K/Ar, Nappi et al., 1995). Single crystal, laser total fusion 40Ar-39Ar dating performed on a new mineral separation from the original six samples of Barberi et al. (1994) gives a well constrained age for the "nenfro" ignimbrite of 498 ka (Laurenzi \& Deino, 1996).

The Bolsena volcanic complex began its activity after the formation of the palaeo-Bolsena caldera and lasted for few hundred thousand years (Palladino et al., 2010, and references therein). It developed mainly in the

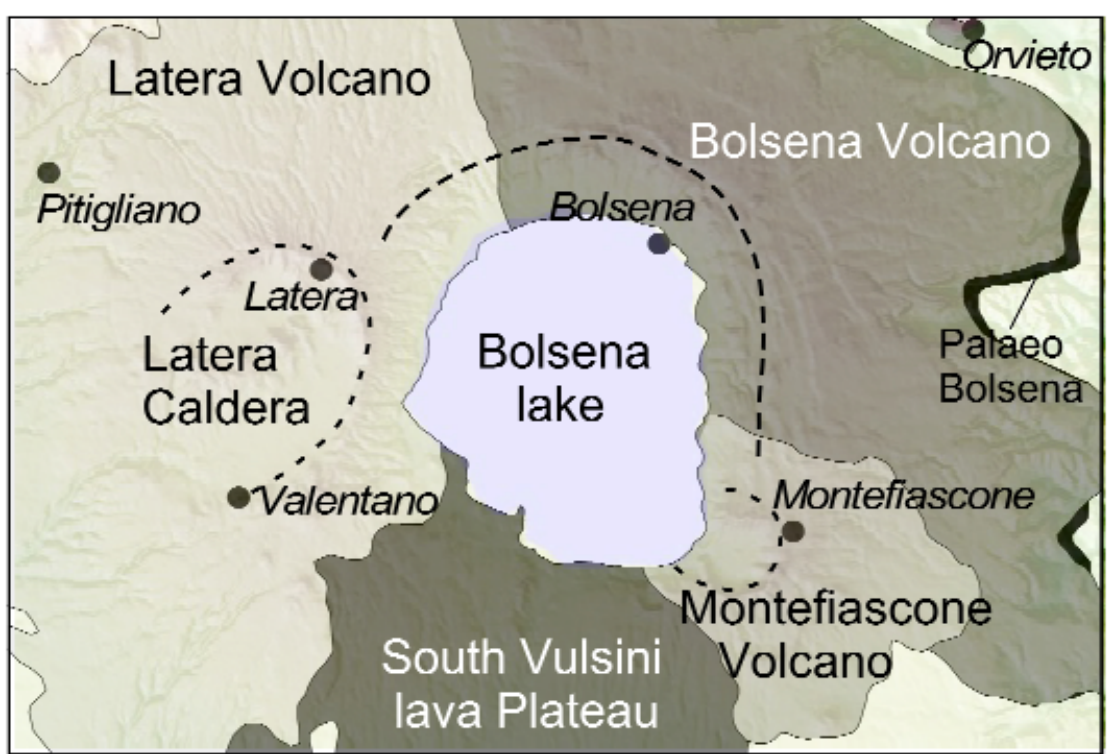

Fig. 85 - The Vulsinian volcanic district of the Roman Magmatic Province is made of the overlap of volcanoes: palaeo-Bolsena, South Vulsin plateau, Bolsena, Montefiascone and Latera. 


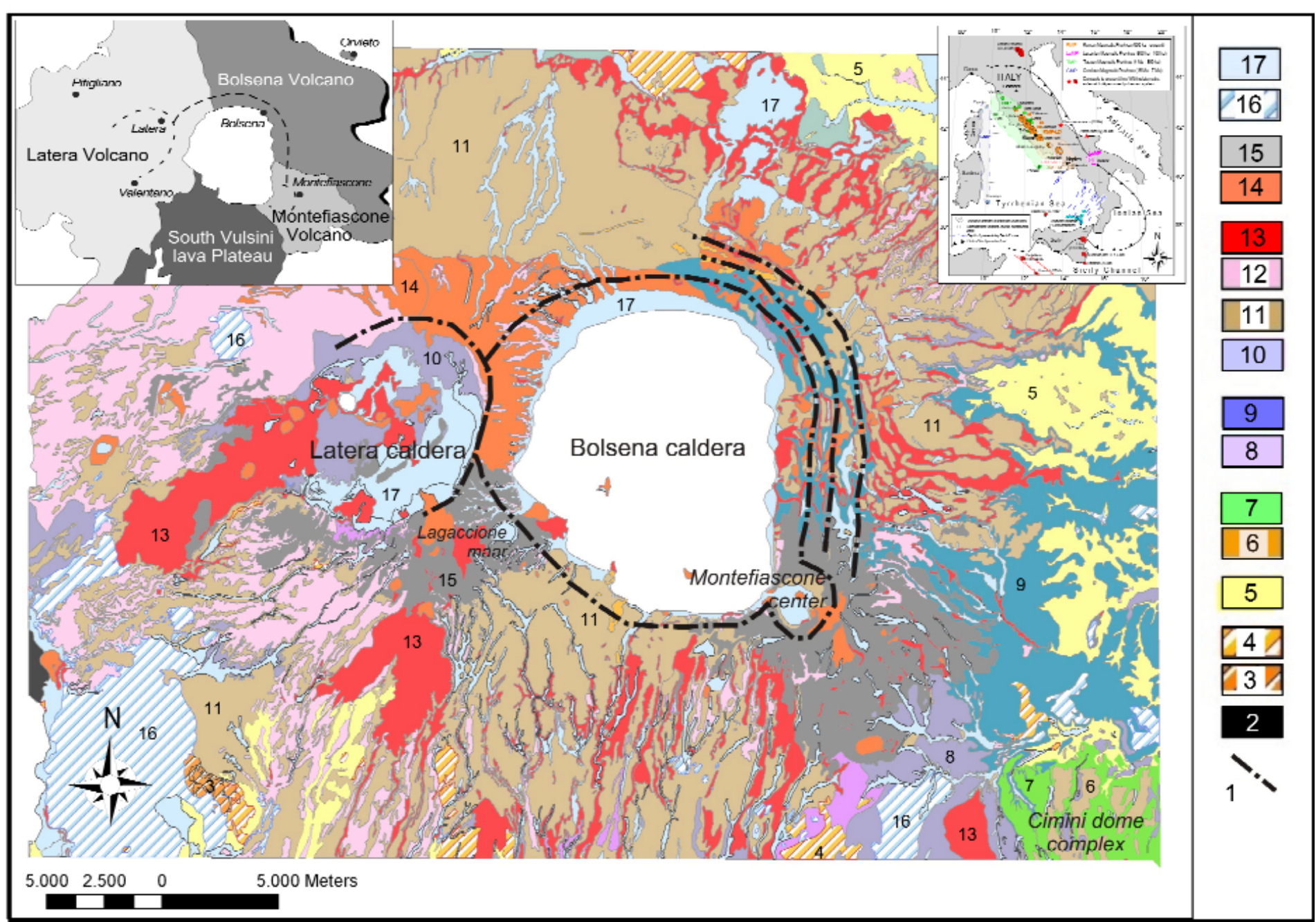

Fig. 86 - Geological sketch map of the Vulsinian volcanic district. Legend: 1) caldera rims; 2) Paleozoic basement; 3) Meso-Cenozoic successions; 4) allochtonous flysch; 5) PliocenePleistocene marine sediments; 6) Cimino: trachydacitic domes; 7) Cimino: trachytic "peperino" ignimbrite; 8) palaeo-Bolsena Volcano welded to unwelded ignimbrites and tuffs; 9) lithoid ignimbrites; 10) spatter-rich ignimbrites; 11) fall-out and reworked pyroclastics; 12) pozzolanaceous ignimbrites; 13) leucite-bearing and free lavas; 14) phreatomagmatic deposits; 15) scoria cones; 16) travertine; 17) Holocene alluvial and lacustrine deposits (redrawn after Conticelli et al., 2010a).

eastern sector of the Vulsinian district with the formation of a large caldera depression partly occupied by the Bolsena Lake and produced two thick ignimbrite sheets, fall deposits and lava flows which built an ignimbrite shield (Freda et al., 1990; Nappi et al., 1998; Palladino et al., 2010). Fissural lava flows, formed a lava plateau south of Bolsena Lake in the Marta-Tuscania area (Palladino et al., 1994).

The Montefiascone Volcano (290 - 230 Ma; Nappi et al., 1995; Brocchini et al., 2000) evolved during the period of activity of Bolsena and partially overlapped the Latera Volcano that developed in the western sector ( 280 $\sim 150 \mathrm{ka}$; Metzeltin \& Vezzoli, 1983; Turbeville, 1992). Both the Montefiascone and the Latera volcanoes are characterised by different activities that led to the formation of a small stratovolcano with a small summit caldera 
(ca. $2.5 \mathrm{~km}$ wide) at Montefiascone, compared to a large flat ignimbritic volcanic plateau with a large central polyphase nested caldera (ca. $9 \mathrm{~km}$ wide) at Latera (Sparks, 1975; Varekamp, 1979, 1980; Conticelli et al., 1986, 1987, 1991; Vezzoli et al., 1987; Coltorti et al., 1991; Turbeville 1992, 1993; Di Battistini et al., 1998, 2001). The final activity is represented by the Bisentina and Martana Islands, in the Bolsena sector, likely by other centres below the Bolsena Lake, tentatively still active around 130ka (K/Ar, Nappi et al., 1995), and by the post-caldera monogenetic volcanoes of Latera.

Composition of the Vulsinian rocks

The volcanic products are mainly characterised by leucite-bearing ultrapotassic rocks (Fig. 87) with few leucite-free shoshonitic rocks confined to the post-caldera activity of

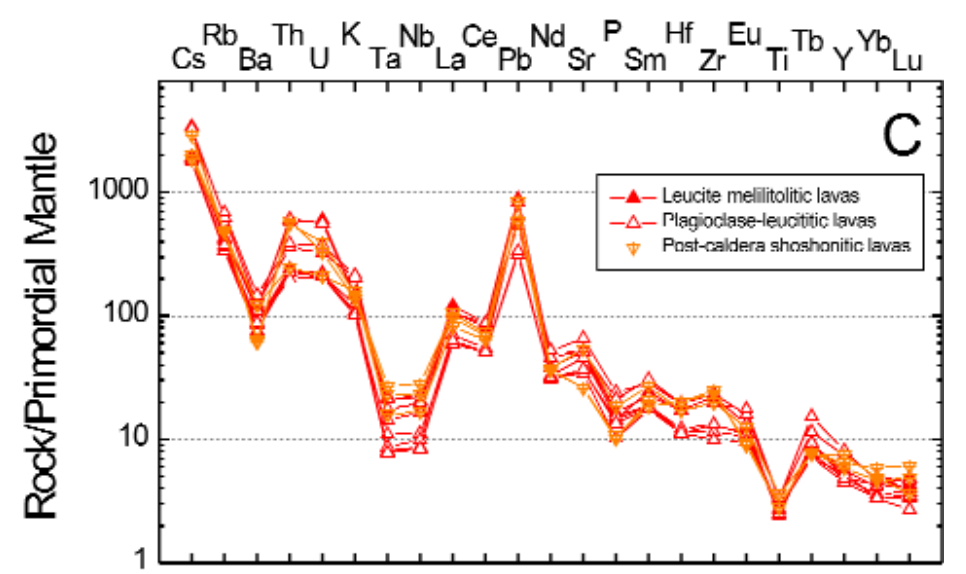
the Latera Volcano (Conticelli et al., 1991) and some melilite-bearing leucitites (kamafugites) confined to the early stages of the Montefiascone Volcano (Di Battistini et al., 2001).

The ultrapotassic rocks of the pre-caldera activities of the three volcanoes range in composition from leucite-bearing basanites to leucitites, tephrites, phonolitic-tephrites, tephritic-phonolites, and phonolites (Fig. 87). Extremely differentiated products dominated volumetrically over mafic ones, but in some cases syn-depositional formation of analcime after leucite allowed $\mathrm{K}_{2} \mathrm{O}$ and alkalis loss, which may have driven the juvenile clasts (pumice) in ignimbrite toward a trachy-phonolitic to trachytic composition (Conticelli et al., 1987; Parker,

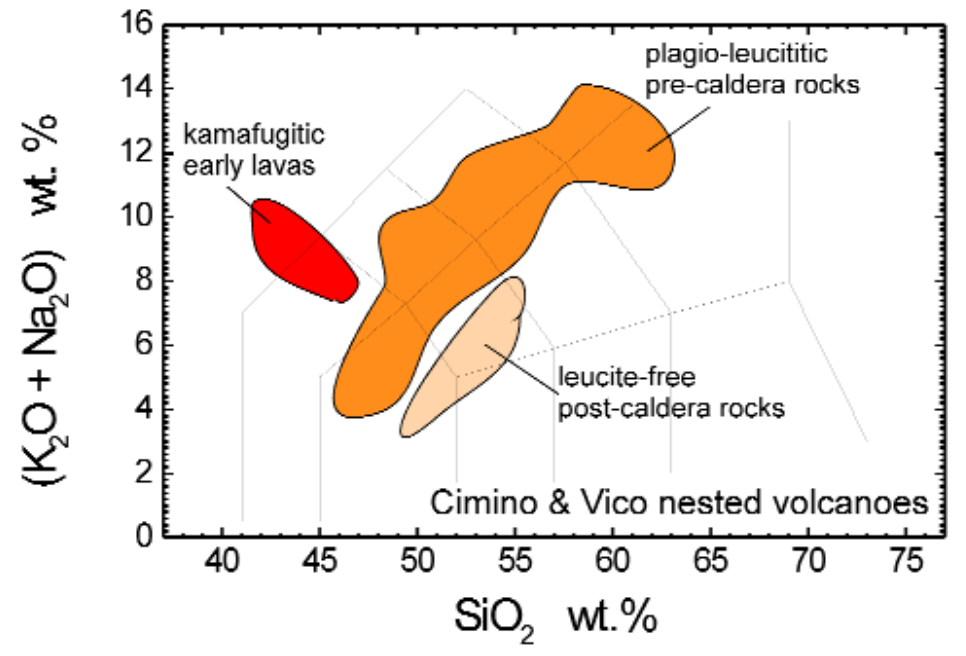

Fig. 87 - Classification and geochemical characteristics of the Vulsini leucitebearing ultrapotassic rocks and associated shoshonitic ones. Total Alkali-Silica (TAS) classification diagram (Le Maitre, 2002). C) Incompatible trace element patterns for mafic volcanic rocks normalised to the primordial mantle values of Sun \& McDonough (1989). Data from Holm et al. (1982); Civetta et al. (1984); Rogers et al. (1986); Conticelli et al. (1987, 1991, 2002, 2007); Coltorti et al. (1991); Di Battistini et al. (2001, 2002); Gasperini et al. (2002). 
1989; Fig. 87). The most mafic compositions are always found among lava flows, mainly in the plateau-like structure of the southern sector of the Vulsinian district and of Montefiascone volcano where leucite-bearing basanitic to tephritic lavas do occur (e.g., Varekamp, 1979, 1980; Civetta et al., 1984; Rogers et al., 1985).

Post caldera activity was particularly intense at the Latera Volcano with bimodal magmatism of both leucite-bearing and -free lavas (Fig. 88). Leucite-bearing post-caldera Latera lavas have compositions ranging from tephritic to tephri-phonolitic, whereas leucite-free lavas are particularly abundant within and external to the caldera in the southern eastern sector of the volcano with the Selva del Lamone lava flow (Fig. 88) and they have a clear shoshonitic affinity with lavas ranging in composition from K-trachybasalts to latites (Fig. 87). The shoshonitic trachybasalts have mineral assemblages made of abundant olivine, clinopyroxene and plagioclase, but they differ significantly in terms of geochemistry to other post-caldera shoshonitic rocks from other volcanic districts of the Roman Province (e.g., Holm et al., 1982; Varekamp \& Kalamarides, 1989; Conticelli et al., 1991, 2009b; Turbeville, 1993).

The most abundant mafic phase in Vulsinian rocks, analogously with other Roman volcanoes, is clinopyroxene, whose composition differs significantly between volcanic rocks where it crystallised in equilibrium with leucite compared and those that are leucite-free. Clinopyroxene from lamproite-like ultrapotassic rocks is generally aluminium poor, with insufficient $\mathrm{Si}+\mathrm{Al}$ to fill the tetrahedral site, whereas clinopyroxene from Roman rocks, either leucite-free or -bearing, is characterised by excess Al that

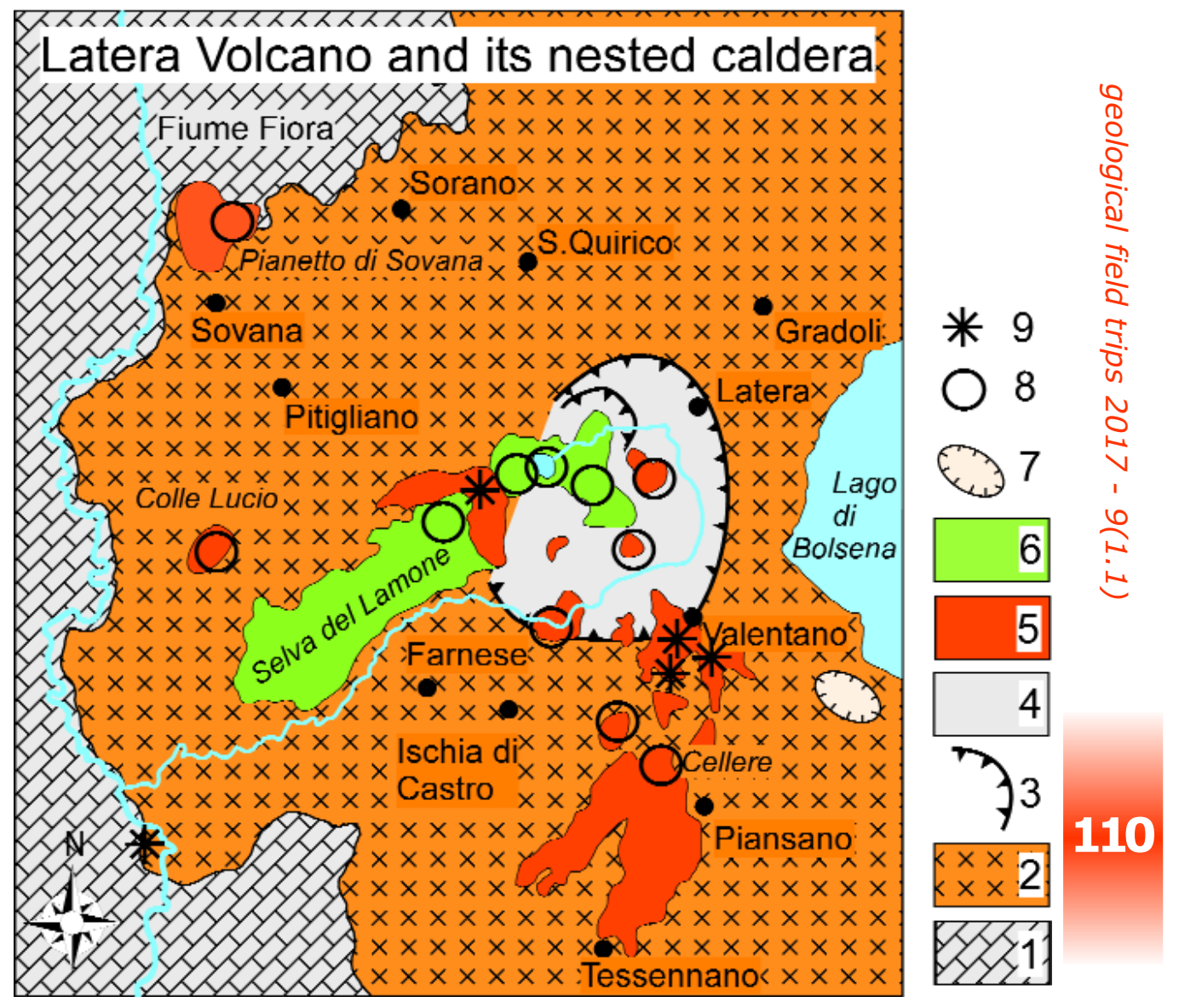

Fig. 88 - Latera Volcano and its nested caldera. Legend: 1) sedimentary substratum, 2) pre-caldera pyroclastic rocks; 3) caldera rims; 4) caldera fill; 5) postcaldera leucititic rocks; 6) post - caldera shoshonitic rocks; 7) maar crater; 8) monogenetic volcanic centre; 9) cinder cone. Redrawn after (Conticelli et al., 1986, 1987, 1991).

DOI: 10.3301/GFT.2017.01 
partitioned between the tetrahedral and octahedral sites (Barton et al., 1982; Holm, 1982; Cellai et al., 1994; Bindi et al., 1999; Chelazzi et al., 2006). Clinopyroxene in shoshonites from Latera Volcano is transitional between the compositions typical of leucite-free Tuscan lamproites and leucite-bearing Roman rocks, whereas that from shoshonites in other Roman districts have excess Al (Cellai et al., 1994; Perini \& Conticelli, 2002; Boari \& Conticelli, 2007). Leucite is found both as phenocrysts and as a groundmass phase in plagio-leucitites and leucitites. Sanidine is present in the most evolved phonolitic and trachy-phonolitic lavas and pyroclastic rocks, and it is also found in leucite-free rocks of the palaeo-Bolsena Volcano and of the post-caldera Latera Volcano. Normalised incompatible trace element patterns of plagio-leucititic volcanic rocks of the Vulsinian district are similar to those of other Roman rocks and of earlier Tuscan ones (Figs 77 and 87), characterised by leucitefree ultrapotassic rocks (i.e., lamproite) and associated shoshonites and calc-alkaline rocks. Vulsinian plagioclase leucititic rocks and associated shoshonites, however, display larger troughs at $\mathrm{Nb}, \mathrm{Ta}$, and $\mathrm{Ti}$, smaller trough at $\mathrm{Hf}$, and a smaller peak at $\mathrm{Sr}$, as well as inversion of the $\mathrm{U} / \mathrm{Th}$ and $\mathrm{Ta} / \mathrm{Nb}$ normalized ratios (Fig. 87), with respect to the older leucite-free ultrapotassic and associated shoshonites and calc-alkaline rocks of the Tuscan magmatic province.

\section{Stops of the afternoon of the $4^{\text {th }}$ day}

You will reach the Vulsinian district after lunch, thus left the Vico Volcano you will approach the Montefiascone Volcano driving through the Cassia road (SS1), an ancient Roman designed consular road. The Montefiascone town is built up on the edge of the caldera of the homonymous volcano and it will be the first Stop of the afternoon of the fourth day.

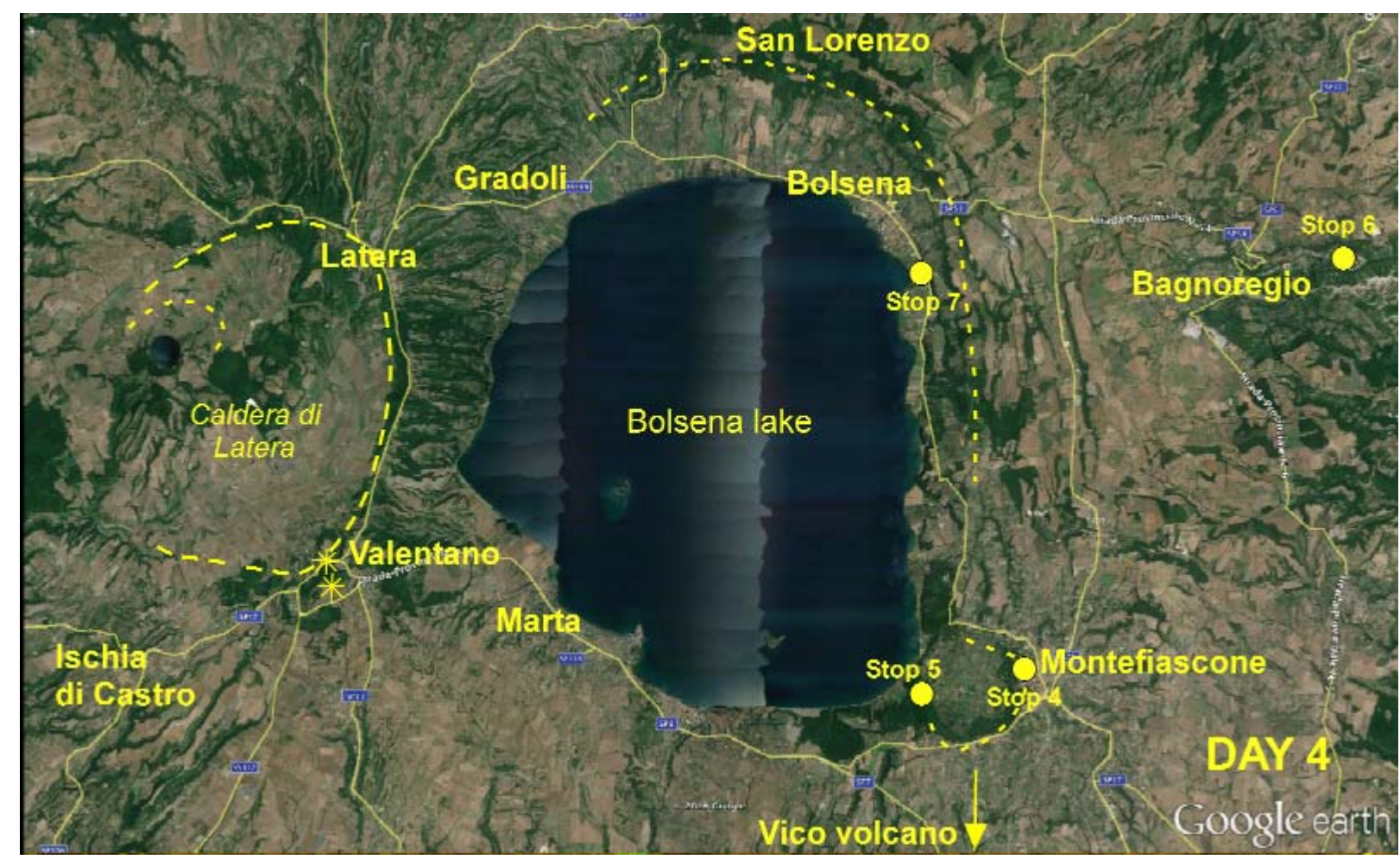

Fig. 89 - Locations of the stops of the afternoon of the fourth day at Vulsinian district. Dashed line show the limit of the caldera. 
The Montefiascone Volcano is located in the southeastern part of the Vulsinian district (Figs 85 and 86 ). The stratovolcano is characterised by mafic lava flows and abundant pyroclastic deposits mostly of hydromagmatic origin. The volcanic rocks of the Montefiascone complex rest on the products of palaeo-Bolsena and Bolsena volcanoes and are covered by the "Sutri ignimbrite" of the Vico stratovolcano (Fig. 86). Emplacement ages of Montefiascone rocks are found to be in the range between 281 and 50 ka (Nappi et al., 1995; Di Battistini et al., 1998, 2001; Brocchini et al., 2000). The explosive activity produced a caldera collapse event, whereas the lava flows were mainly erupted from E-W trending fractures close to the caldera rim. The activity of the Montefiascone complex ended with weak Strombolian eruptions occurring along the caldera rim (Fig. 86). Once in the Montefiascone town you will leave the Cassia road, turning left in via Bandita, to reach the lookout terrace in front of the Northwest gate of the old town from where you will have a panoramic outlook of the Montefiascone caldera with the Bolsena Lake on the backgrund (Fig. 90).

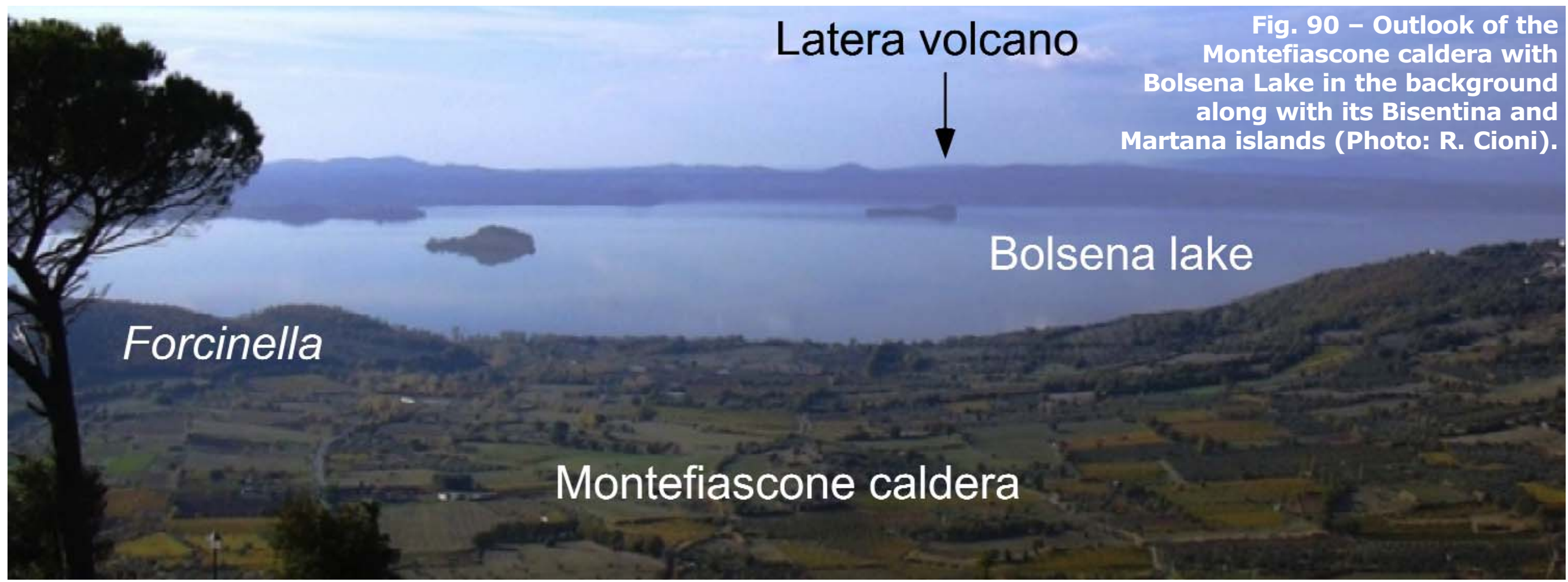


STOP 4.5: Montefiascone Volcano, the melilitite of the caldera wall $\left(42^{\circ} 32^{\prime} 23^{\prime \prime} \mathrm{N}-11^{\circ} 59^{\prime} 31^{\prime \prime} \mathrm{E}\right)$

Melilite-bearing kamafugitic rocks are very rare in the Latian districts whilst they are almost the exclusive rock type in the intraApennine Umbrian district of the Roman Magmatic Province (Conticelli et al., 2015a, and references therein). In the Latian districts the few melilite-bearing rocks are confined in the early phase of activity of three districts: 1) middle Latin Valley volcanic field (e.g., Boari \& Conticelli, 2007; Boari et al., 2009b); 2) Colli Albani Volcano (e.g., Fornaseri \& Scherillo, 1963; Boari et al., 2009a; Conticelli et al., 2010b); 3) Montefiascone Volcano of the Vulsinian district (Di Battistini et al., 2001).

At Montefiascone volcanoes the ultrapotassic melilitite-bearing lava flows with kamafugitic affinity are found at the bottom of the caldera wall indicating its early emplacement (Fig. 91). These lavas are found in the Forcinella area at the bottom of the southeastern of the caldera wall, with the outcrop reaching a maximum length of $250 \mathrm{~m}$ and a thickness of 1-2 $\mathrm{m}$. They consist of blue-grey massive rocks characterised by small and rare leucite phenocrysts visible in hand specimen (Di Battistini et al., 2001). The stratigraphic succession and the distribution of the volcanic products in this area are reported in the map of figure 91 . The melilitite lavas are covered by $70 \mathrm{~cm}$ of reworked pyroclastic deposits and by a thin dark-brown palaeosoil. The stratigraphic base of the lava flow is not exposed.

Leucite melilititic lavas are weakly porphyritic, feldspar-free lavas with euhedral phenocryst of leucite and microphenocrysts of clinopyroxene and melilite set in a groundmass made of leucite, olivine, clinopyroxene, kalsiite, Fe-Ti oxides and interstitial phlogopite and carbonates (Di Battistini et al., 2001). The Montefiscone kamafugitic lavas are ultrapotassic and in

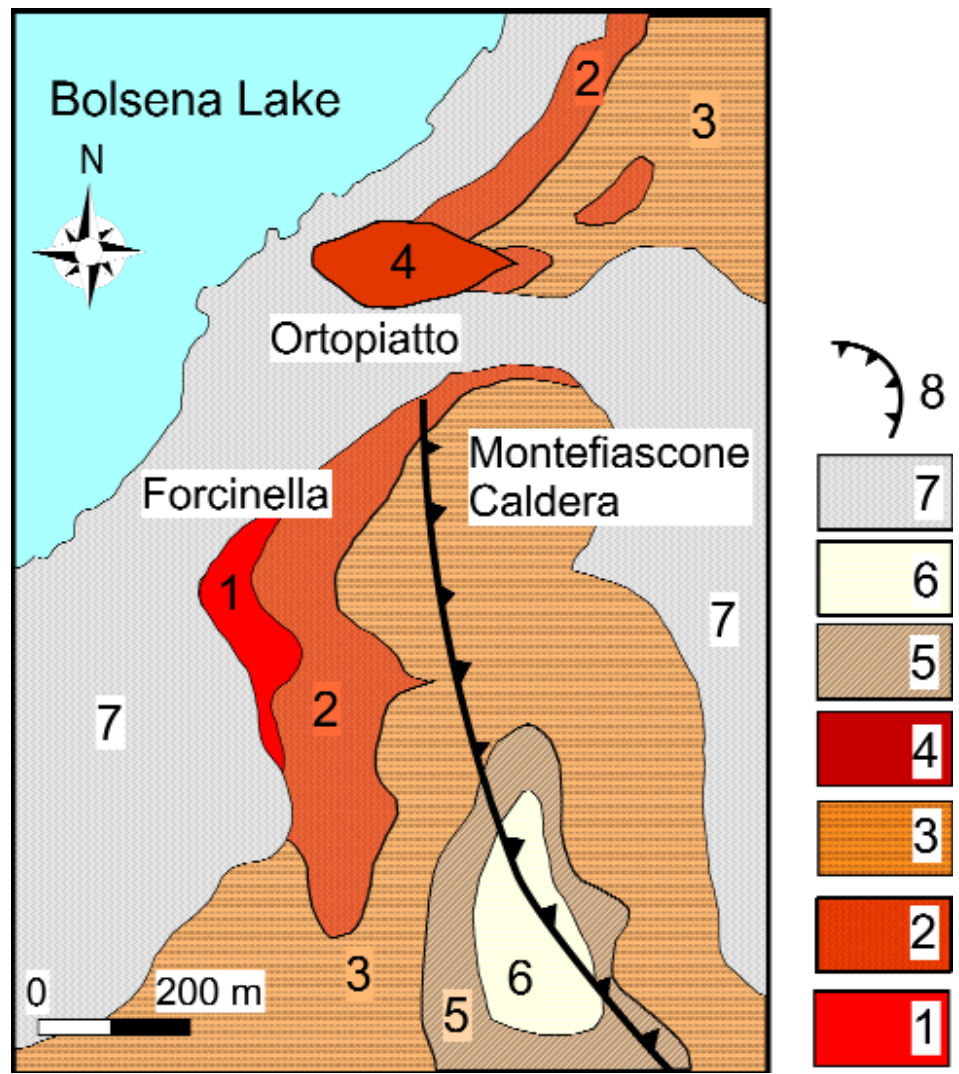

Fig. 91 - Geological map of the volcanic succession in the Forcinella area at Montefiascone Volcano. Legend: 1) Forcinella melilitite lava flow; 2) Forcinella spatter cone; 3) intermediate hydromagmatic pyroclastic rocks; 4) Ortopiatto basanite lava flow; 5) upper hydromagmatic pyroclastic flow; 6) uppermost hydromagmatic pyroclastic rocks; 7) Quaternary sediments; 8) caldera rim (redrawn after Di Battistini et al., 2001). DOI: $10.3301 / G-F .2017 .01$ 
the TAS diagram they straddle the boundary between basanites and foidites, showing lower $\mathrm{SiO}_{2}, \mathrm{Al}_{2} \mathrm{O}_{3}, a_{n} \mathrm{Na}_{2} \mathrm{O}$, higher $\mathrm{CaO}$, with respect to other vulsinian plagio-leucitites (Fig. 87).

Distribution of incompatible trace elements of Montefiascone kamafugite is similar to that of other Vulsinian rocks but differs significantly, in terms of $\mathrm{Nb} / \mathrm{Ta}$ and $\mathrm{Zr} / \mathrm{Hf}$, from Umbrian melilitites (e.g., Conticelli \& Peccerillo, 1992; Peccerillo, 1998, 2004, 2005a, b; Di Battistini et al., 2001).

STOP 4.6: Civita di Bagnoregio, the distal deposits of the Bolsena Volcanic complex $\left(42^{\circ} 37^{\prime} 34^{\prime \prime} \mathrm{N}-\right.$ $12^{\circ} 06^{\prime} 34^{\prime \prime} E$ )

The village of Civita di Bagnoregio is located on the eastern Vulsinian districs and it is build up over a pyroclastic sequence of the Bolsena Volcano (Fig. 89). The volcanic pile is made up by pyroclastic flow and fall deposits that rest over a substratum made up by Lower Pleistocene marine shales. Erosion of the shales at the foot of the hill brings the slopes of the Civita di Bagnoregio hills to be unstables. You will observe the typical erosional phenomena along with the details of the volcanic succession and the depositional characters of pyroclastic deposits.

STOP 4.7: thrown stones (autoc. "pietre lanciate") (42'37'57"N - 11'59'49"E)

The "thrown stones" is an outcrop showing columnar jointing. The phono-tephritic lavas were outpoured by a N$\mathrm{S}$ fracture along the rim of the Bolsena collapsed area. The western dip of the joints suggests an eastward flow of the lava on a high angle slope directed to the Bolsena Lake (Fig. 93).
Fig. 92 - Civita di Bagnoregio is built on a thick sequence of pyroclastic falls and surge interbedded with ignimbrites of the Bolsena Volcano. The pyroclastic sequence lie on marine shale of Pliocenic age (Photo: S. Conticelli).

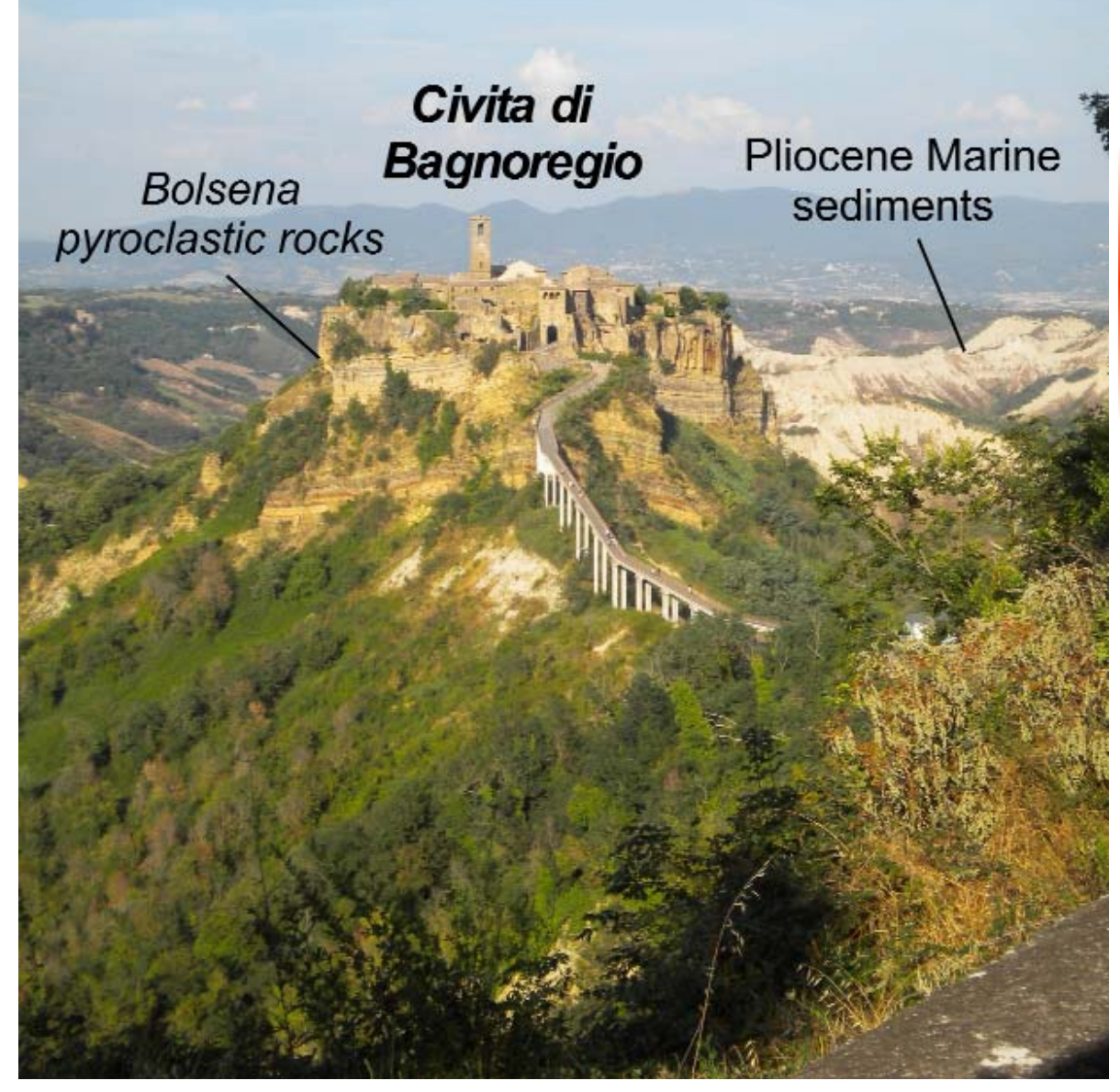




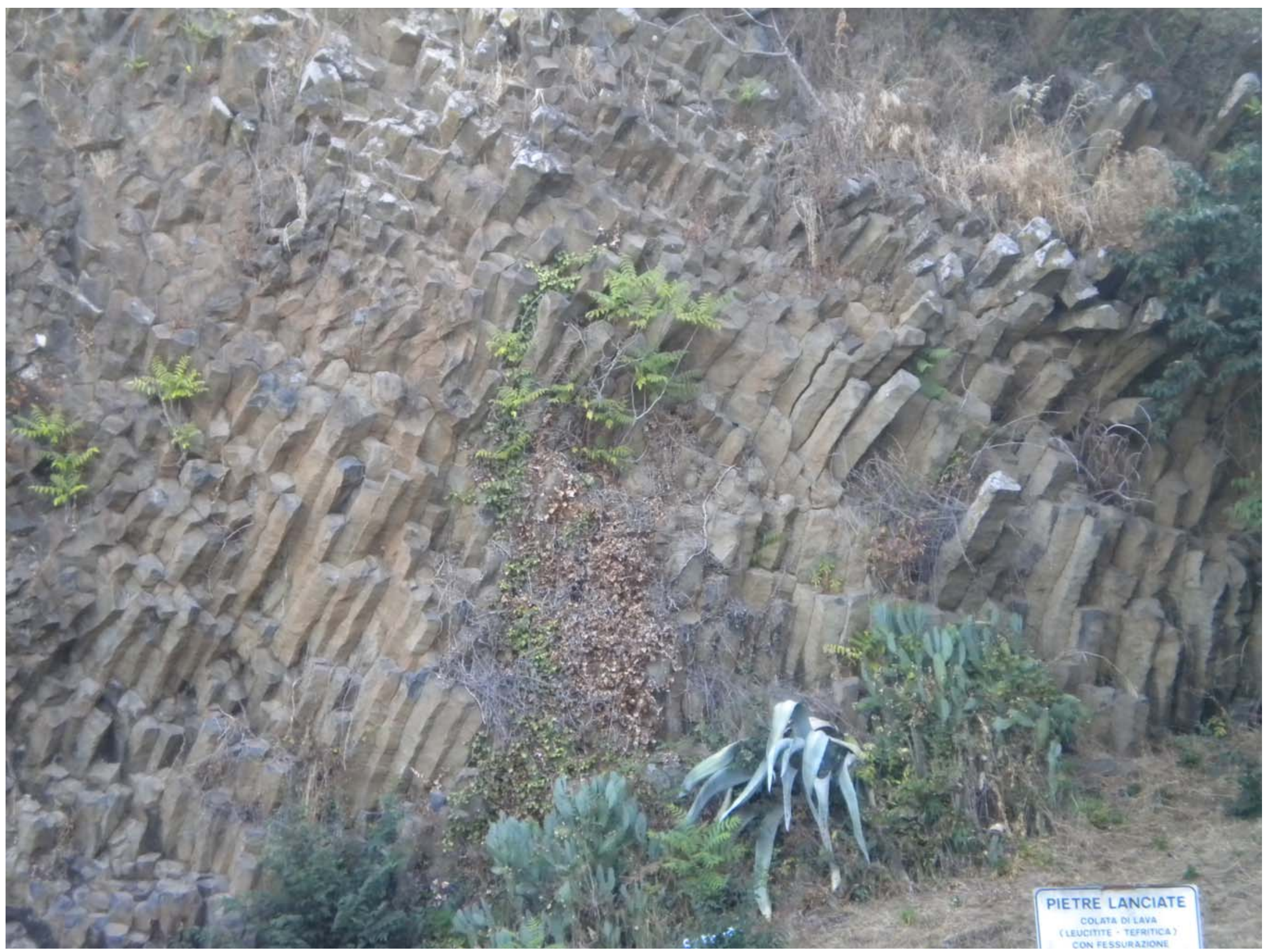

Fig. 93 - Columanr jointing in phonolitic tephrites South of Bolsena town (Photo: S. Conticelli). 


\section{Day 5: the Tuscan Magmatic Province}

The Tuscan and Tyrrhenian regions were the sites of bimodal igneous activity during the Pliocene and Pleistocene (Fig. 94). Mantle-derived ultrapotassic magmas with associated shoshonitic and high-K calc-alkaline ones were produced by partial melting of a pyroxenitic metasomatised upper mantle (e.g., Conticelli et al., 2002, 2007, 2009b, 2011; Avanzinelli et al., 2009; Ammannati et al., 2016) and they emplaced mainly in the Italian peninsula (Fig. 94), with few outcrops at Elba Island (Monte Castello dike, Conticelli et al., 2001).

Crustal-derived magmas originated by partial melting of lower to intermediate continental crust (i.e., anatexis) formed granitic to grano-dioritic plutonic bodies mainly emplaced in the Tyrrhenian region and in the westernmost area of the Northern Italian Peninsula (Tyrrhenian anatectic Province, Fig. 94). The occurrence of shallow level anatectic "granitic" s.l. magmas in the Tyrrhenian region did not allow the arrival of mantlederived magma at surface. Indeed most of the anatectic "granitic" and "rhyolitic" rocks show evidences of interaction at variable extension with mafic mantle derived ones (e.g., Poli et al., 1984, 1989; Peccerillo et al., 1987; Pinarelli et al., 1989; Poli, 1992, 1996; Westermann et al., 1993; Poli et al., 2004; Gagnevin et al., 2005a, b, 2007; Poli \& Peccerillo, 2016). Once anatectic magmatism exhausted, at about 2 Ma (Fig. 94), mantle derived magmas reached the surface, preserving their primary compositional and mineralogical characteristics, emplaced several small hypabissal bodies and volcanoes in Central-Southern

Fig. 94 - Distribution of volcanism in Northern Italian Peninsula: 1) Corsican Magmatic Province (14.5-4.6 Ma); 2) Tyrrhenian Anatectic Province (8.5-2.3 Ma); 3) Tuscan Magmatic Province (5.9-0.95 Ma); 4) Roman Magmatic Province - Latian Districts 0.6-0.05 Ma); 5) Roman Magmatic Province - Umbrian district (0.4 Ma); 6) Amiata hybrid province. Redrawn after (Conticelli et al., 2011, 2013, 2015a, b).

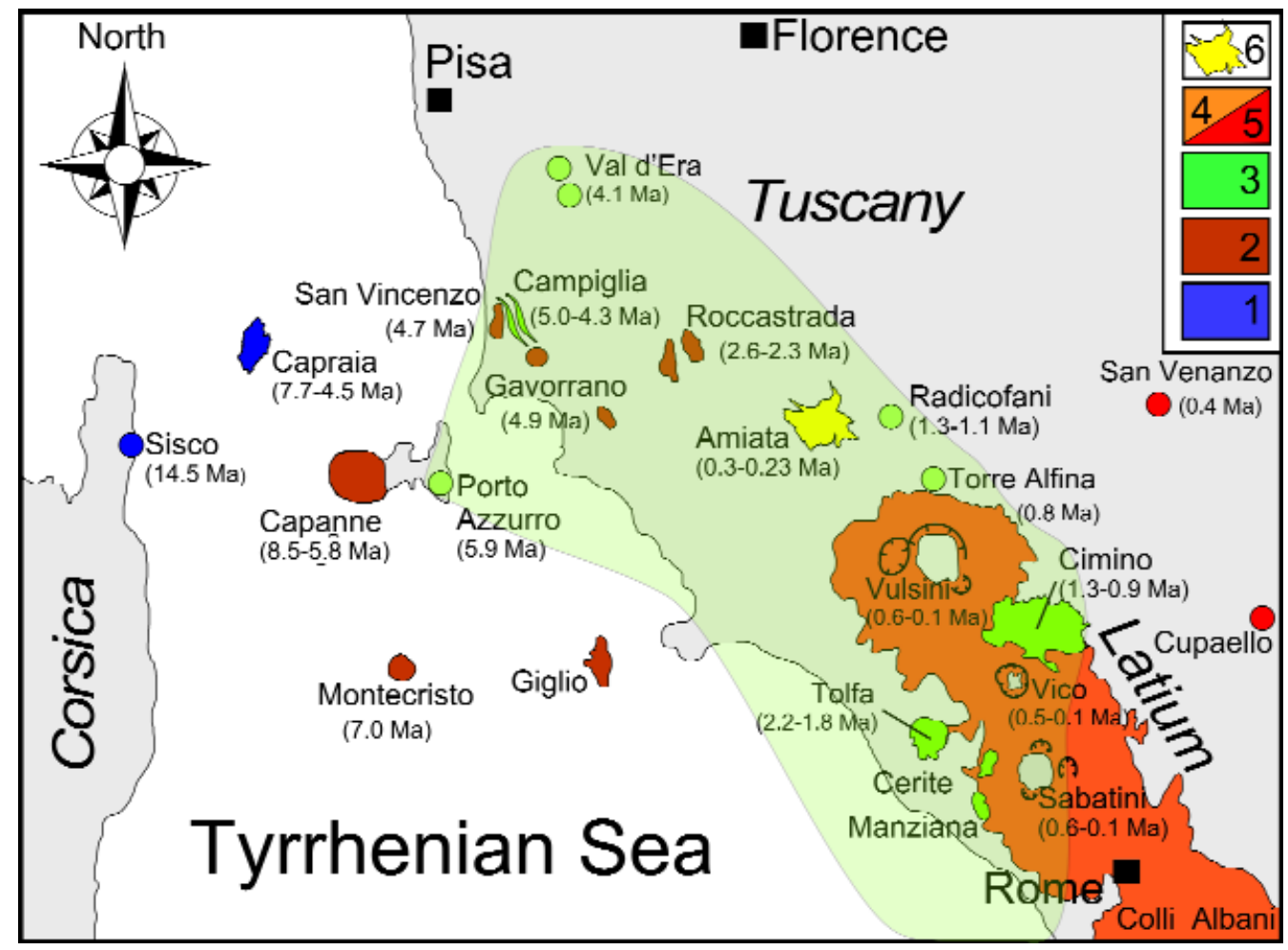


Tuscany made up of high-K calc-alkaline, shoshonitic, and plagioclase- and leucite-free alkaline ultrapotassic rocks (i.e., lamproite; Conticelli et al., 2009a). The mantle-derived igneous rocks of the Tuscan Magmatic Province are found as scattered outcrops straddling the Tyrrhenian border of the Italian Peninsula (Fig. 94). Traditionally the Tuscan Magmatic Province was considered to be confined within the administrative border of the Tuscany region (Peccerillo et al., 1987; Innocenti et al., 1992; Poli et al., 2004), but coeval leucite-free potassic to sub-alkaline magmatic mafic rocks have been found along the entire Tyrrhenian border of the peninsula in the Campanian plain and offshore in the Pontine archipelago (e.g., Di Girolamo et al., 1979; Barbieri et al., 1979; Avanzinelli et al., 2009). In this guide, however, we will not deal with those Pliocenic leucite-free rocks outcropping out of the "classic" Tuscan Magmatic Province.

The oldest volcanic rocks of the Tuscan Magmatic Province are found at Elba Island, in the archipelago betwenn Italian Peninsula and Corsica (Fig. 94) with a 40Ar-39Ar age of 5.89 Ma (Conticelli et al., 2001). These were followed by the emplacement, in the mainland, of the Val d'Era lamproites made up of the hypoabissal minette of Montecatini Val di Cecina, emplaced at 4.1 Ma (K/Ar; Borsi et al., 1967), of the orendite of Orciatico (Conticelli et al., 1992), and of the olivine latitic dikes at Campiglia (Conticelli, 1989).

The magmatic activity in the Tolfa-ManzianaCerite dome complexes (Fig. 96) started coevally with the Val d'Era lamproites. These rocks are composed by trachytic to rhyodacitic domes, massive lava flows, and welded ignimbrites, but latitic to olivine latitic mafic enclaves are also indicative of a common origin and evolution to the Monte Cimino volcanic complex (e.g., Fazzini et

Fig. 95 - The Radicofani Volcano is a relic of a small edifice of the Tuscan Magmatic Province that erupted ultrapotassic shoshonite to calc-alkaline basalts showing evidence of neither chemical nor mineralogical interaction with crustal-derived magmas (Conticelli et al., 2011)(Photo: M. Marroni courtesy).

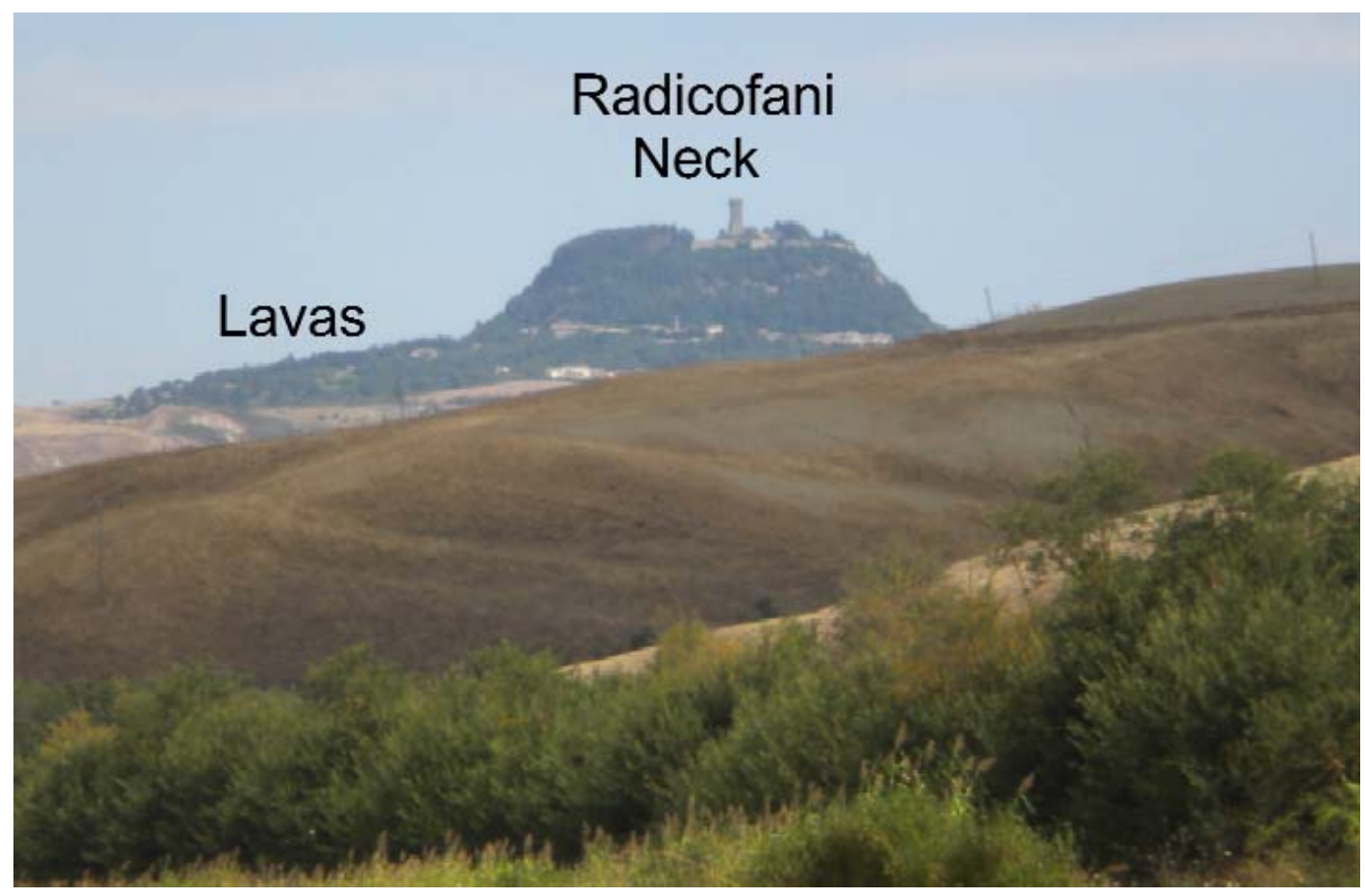


al., 1972; Clausen \& Holm, 1990; Pinarelli, 1987, 1991; Bertagnini et al., 1995). Several K/Ar dates are available for the Tolfa-Manziana-Ceriti volcanic rocks and range from 4.3 to $1.9 \mathrm{Ma}$, excluding a datum from a xenolith (Evernden \& Curtis, 1965; Bigazzi et al., 1973; Lombardi et al., 1974; Villa et al., 1989). Villa et al. (1989) performed a new mineral separation on four rocks previously analysed by Lombardi et al. (1974), and obtained ages overlapping within error for the Tolfa and Manziana samples, all around $3.5 \mathrm{Ma}$. Villa et al. (1989) explain the discrepancies observed between the old and new analyses with the use of mixed mineral phases by Lombardi et al. (1974) during their experiments. A fairly young age, $2.36 \mathrm{Ma}$, on a sanidine with stoichiometric K in K-feldspar is reported also by Evernden \& Curtis (1965).

The youngest leucite-free ultrapotassic rocks of the Tuscan Magmatic Province are found further East, erupted along the NNW-SSE extensional basin that would be filled later, during the Pleistocene, by the Roman leucitebearing volcanic rocks. The emplacement of the basaltic andesitic to shoshonitc lavas of Radicofani center (Fig. 94) occurred around 1.3 Ma (Pasquarè et al., 1983; D'Orazio et al., 1991). K/Ar model ages on the olivine latite with lamproitic affinity and latite to trachytes with shoshonitic affinity of the Monte Cimino Volcanic complex fall within the interval between 1.43 and 0.97 Ma (Evernden \& Curtis, 1965; Nicoletti et al., 1969; Puxeddu, 1971; Sollevanti, 1983; Laurenzi et al., 2014), partially overlapping with Radicofani volcanic rocks. A new $40 \mathrm{Ar}-39 \mathrm{Ar}$ age of $0.85 \mathrm{Ma}$ was recently published for the Torre Alfina Volcano (Laurenzi et al., 2015b).

Fig. 96 - Geological sketch map of the Tolfa-ManzianaCerite dome complex. Legend: 1) marly limestones; 2) turbiditic sandstones; 3) volcanic rocks of Tolfa-ManzianaCerite; 4) volcanic rocks of Vico Volcano; 5) volcanic rocks of the Sabatinian district; 6) Neogene sediments (from Pinarelli, 1987).
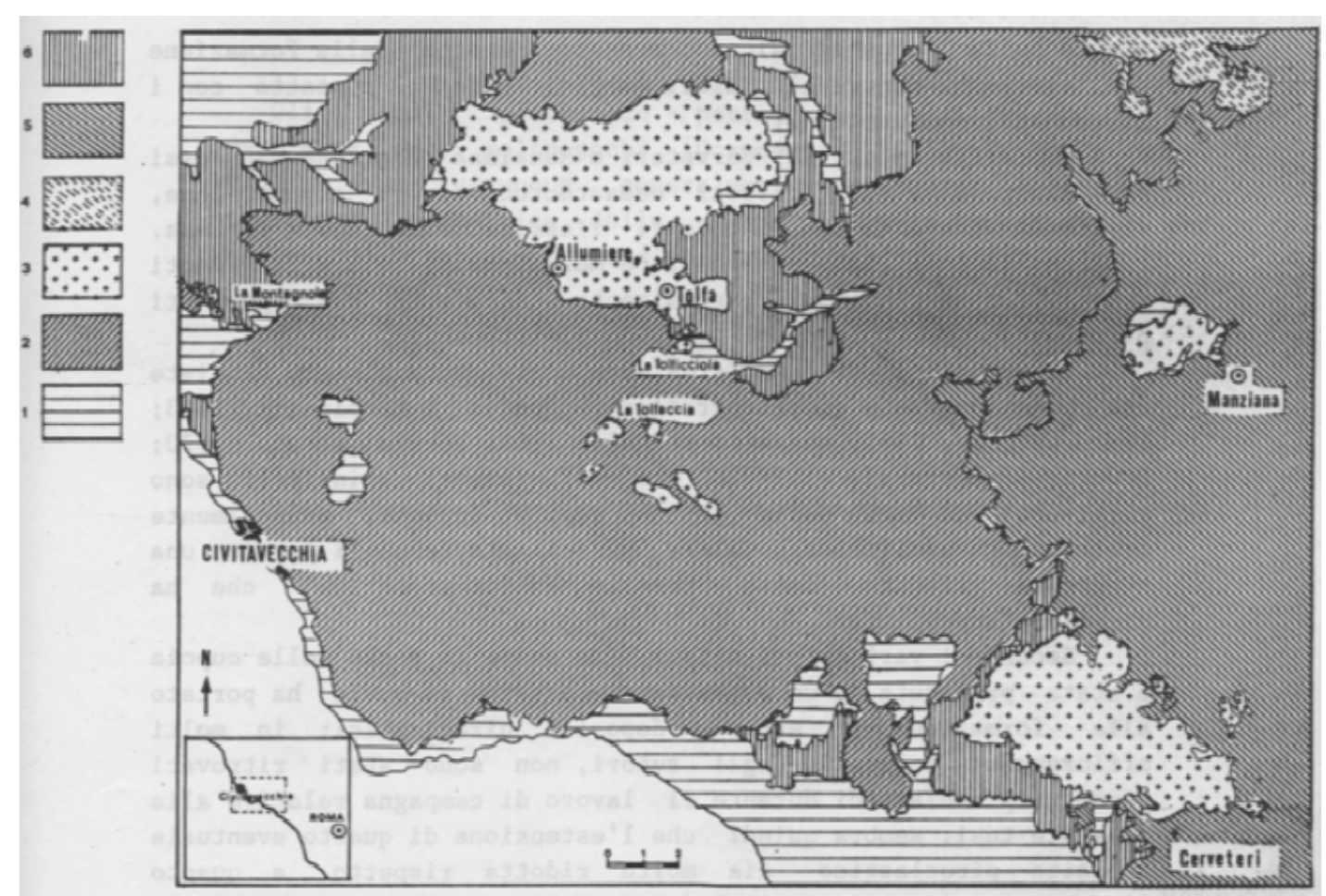
Chemical and petrographic characteristics of Tuscan Magmatic Province

The rocks of this province range in composition from ultrapotassic (i.e., lamproite-like) to shoshonitic and high-K calc-alkalic rocks (Fig. 97). Shoshonitic rocks are represented by the overall spectrum of compositions, from trachybasalt to trachyte, as well as high- $\mathrm{K}$ calc-alkalic rocks ranging from high- $\mathrm{K}$ basaltic andesites to rhyolites (Fig. 97).

Lamproite-like rocks in Tuscany are scarce, mostly mafic with phenocrysts of Al-poor clinopyroxene and chromitehosting high-forsterite olivine set in a groundmass made of phlogopite, sanidine, clinopyroxene, K-richterite, apatite, picroilmentite, Ti-magnetite and accessory perrierite/chevkinite (Wagner \& Velde, 1986; Conticelli et al., 1992; Cellai et al., 1993, 1994; Conticelli, 1998; Conticelli et al., 2013, 2015a). The aluminium content in clinopyroxene
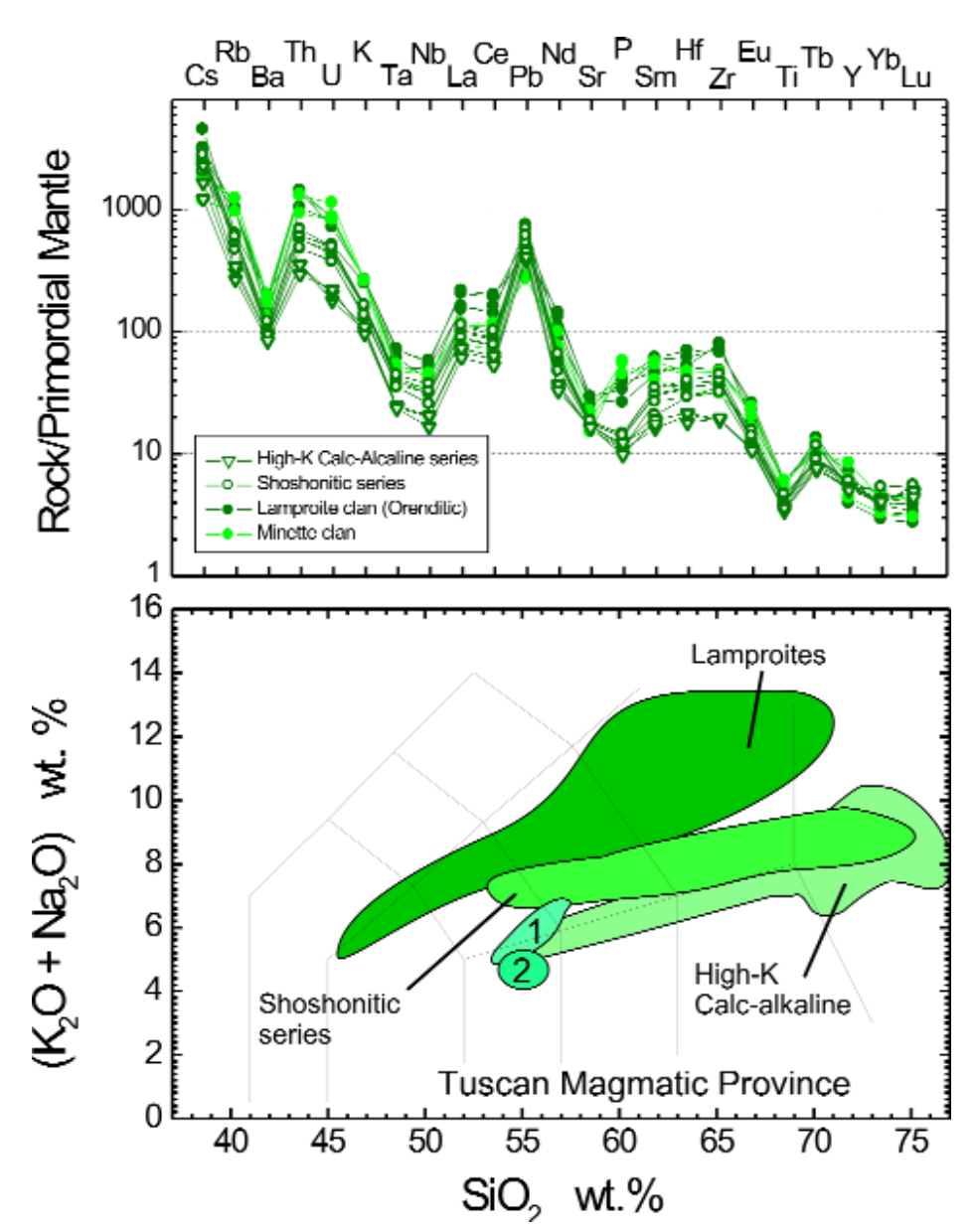
increases from lamproite to shoshonite with contemporaneous appearance of plagioclase. Two-pyroxenes high-K calc-alkaline rocks are strongly differentiated products at Cimino, Tolfa, Manziana, and Ponza volcanic centres. They are associated with either younger mafic lamproite-like shoshonitic rocks or with lamproite-like mafic enclaves (Clausen \& Holm, 1990; Pinarelli, 1991; Perini et al., 2003; Conte \& Dolfi, 2002; Paone, 2004; Cadoux et al., 2005). Equilibrium between clinopyroxene and orthopyroxene is the main petrographic characteristic of the most differentiated terms, which are associated with biotite, sanidine, plagioclase, apatite, zircon, ilmenite, Ti-magnetite.

The mafic Plio-Pleistocene magmatic rocks of the peri-Tyrrhenian area have variable $\mathrm{K}_{2} \mathrm{O}$ and incompatible elements contents showing a temporal decrease in the contents of this oxide. High-MgO volcanic rocks, irrespectively of their $\mathrm{K}_{2} \mathrm{O}$ content, display strong depletions in

Fig. 97 - TAS (Le Maitre, 2002) and spider (Sun \& McDonough, 1989) diagrams for Tuscan ultrapotassic lamproites and associated rocks. Note: 1) Radicofani; 2) Monte Castello dyke. Data from Metrich et al. (1988); Peccerillo et al. (1987, 1988); Pinarelli (1991); Conticelli \& Peccerillo (1992); Conticelli et al. (1992, 2002, 2007, 2009a, 2011, 2013); Conticelli (1998); D'Antonio et al. (1994); Cadeaux et al. (2005). 
$\mathrm{Ti}$, Ta, and Nb relative to Th and LILE (Fig. 97). When compared to Corsican rocks, the Plio-Pleistocenic volcanic rocks of Tuscany show higher peaks at $\mathrm{Th}, \mathrm{U}, \mathrm{Pb}, \mathrm{Zr}$ and $\mathrm{Hf}$, and deeper troughs of $\mathrm{Ba}, \mathrm{Ta}, \mathrm{Nb}, \mathrm{P}$, and $\mathrm{Ti}$ (Fig. 97). These rocks still dispay normalized Ta/Nb and Nd/Sr lower than one. Conticelli \& Peccerillo (1992) argued that incompatible trace element concentrations and their distribution and fractionation are primary characteristics derived directly from their mantle source(s) due to sediment recycling within the upper mantle.

The Monte Amiata: a Quaternary "hybrid" volcano

The Monte Amiata Volcano, Late Pleistocene in age, is located tens of km North of the Vulsini district (Fig. 94) and few km west of then Radicofani Volcano (Fig. 98). It is found where the Roman and Tuscany magmatic provinces overlaps in space, but not in time (Conticelli et al., 2004, 2010).

The Monte Amiata Volcano is a small fissural volcano that produced one large collapsed dome, several exogenous domes, and some viscous (massive) to fluid lava flows (Fig. 98) with high-K calc-alkaline to shoshonitic affinities. The apical domes are feeded by a NNE-SSW volcanic fissure with final products clustering the northeastern termination of the eruptive fissure (Fig. 98). The volume of magma produced is extremely small with respect to he amount of magmas erupted in Roman volcanoes, but consistenly larger than that produced by Tuscan volcanoes.

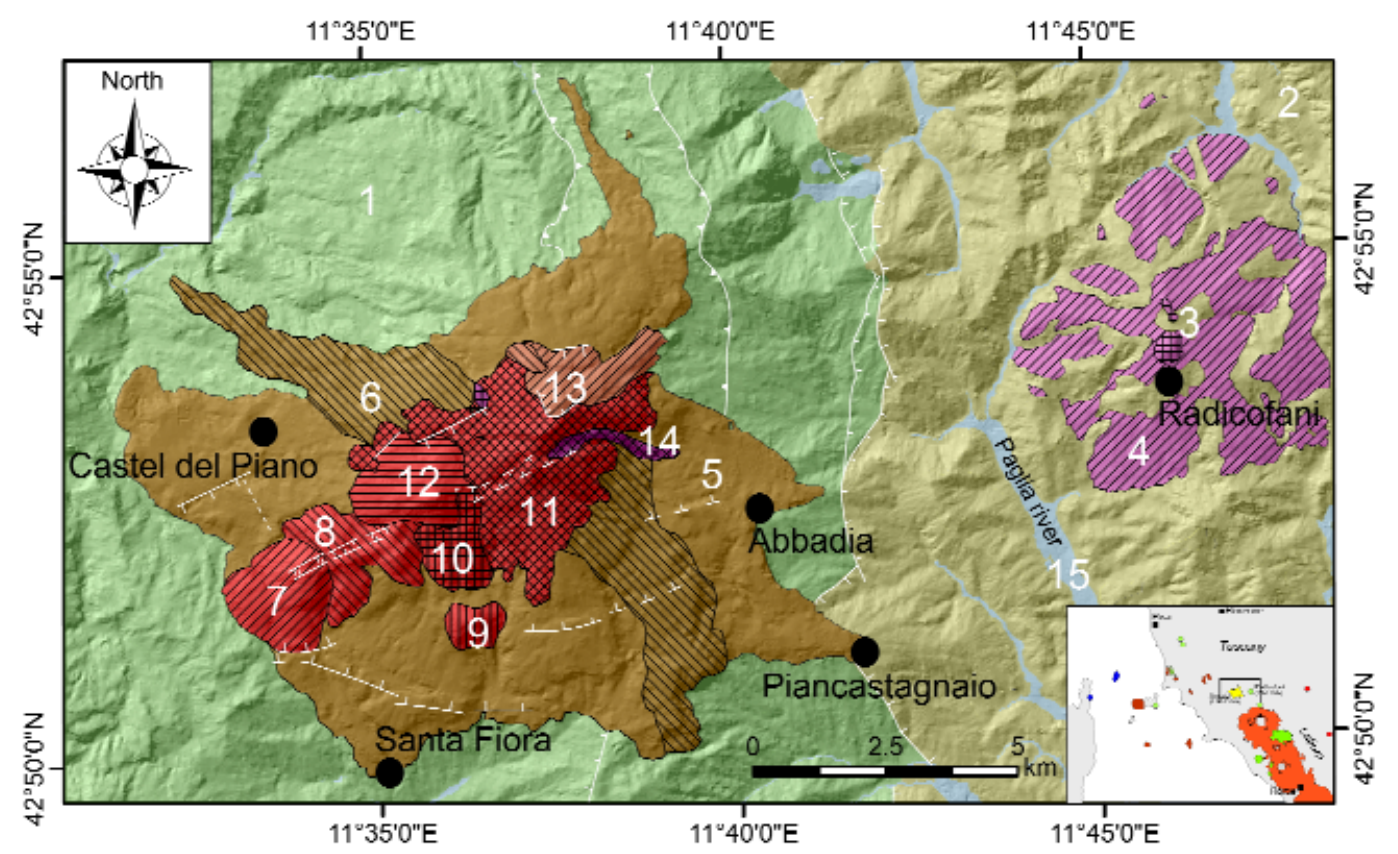

The chronology of Monte Amiata Volcano relies on several $\mathrm{K} / \mathrm{Ar}$ and fission track data (Evernden \& Curtis, 1965; Bigazzi et al., 1981; Pasquaré et al., 1983; Cadoux \& Pinti, 2009), and few 40Ar-39Ar data (Laurenzi \& Villa, 1991; Barberi et al., 1994;

Fig. 98 - Geological sketch map of the Amiata region. Legend: 1) sedimentary sequences of the ligurid units; 2) Pliocene marine sediments; 3-4) Radicofani Volcano, neck and dismembered lavas, respectively; 5-14) Monte Amiata Volcano; 5-6) collapsed trachydacitic dome and massive lava flows (6); 7-11) trachytic domes and massive lava flows; 13) latitic lava flows; 14) olivine latitic lava flows; 15) Quaternary alluvial deposits (redrawn after Conticelli et al., 2015b, c; Laurenzi et al., 2015a; Marroni et al., 2015). 
Laurenzi et al., 2015a). Recently, Laurenzi et al. (2015a) published some new 40Ar-39Ar dating and an updated evaluation of all the geochronological data performed on Amiata rocks (Fig. 99). On the basis of this reevaluation, the onset of magmatic activity of Monte Amiata was set at $305 \mathrm{Ma}$, with apical domes emplaced in a short interval of time, from 301 to $294 \mathrm{ka}$, and one of the final lava flows at $230 \mathrm{ka}$ (Laurenzi et al., 2015a, b). In summary, the Amiata Volcano is much younger than any other Tuscan volcanoes (leucite-free ultrapotassic rocks) and well within the time span of Roman volcanic rocks (leucite-bearing ultrapotassic rocks), although no leucite has been found in any Amiata rocks (Conticelli et al., 2015b).

The Monte Amiata volcanic rocks vary in composition with time from trachydacites to trachyte, latite, and olivine

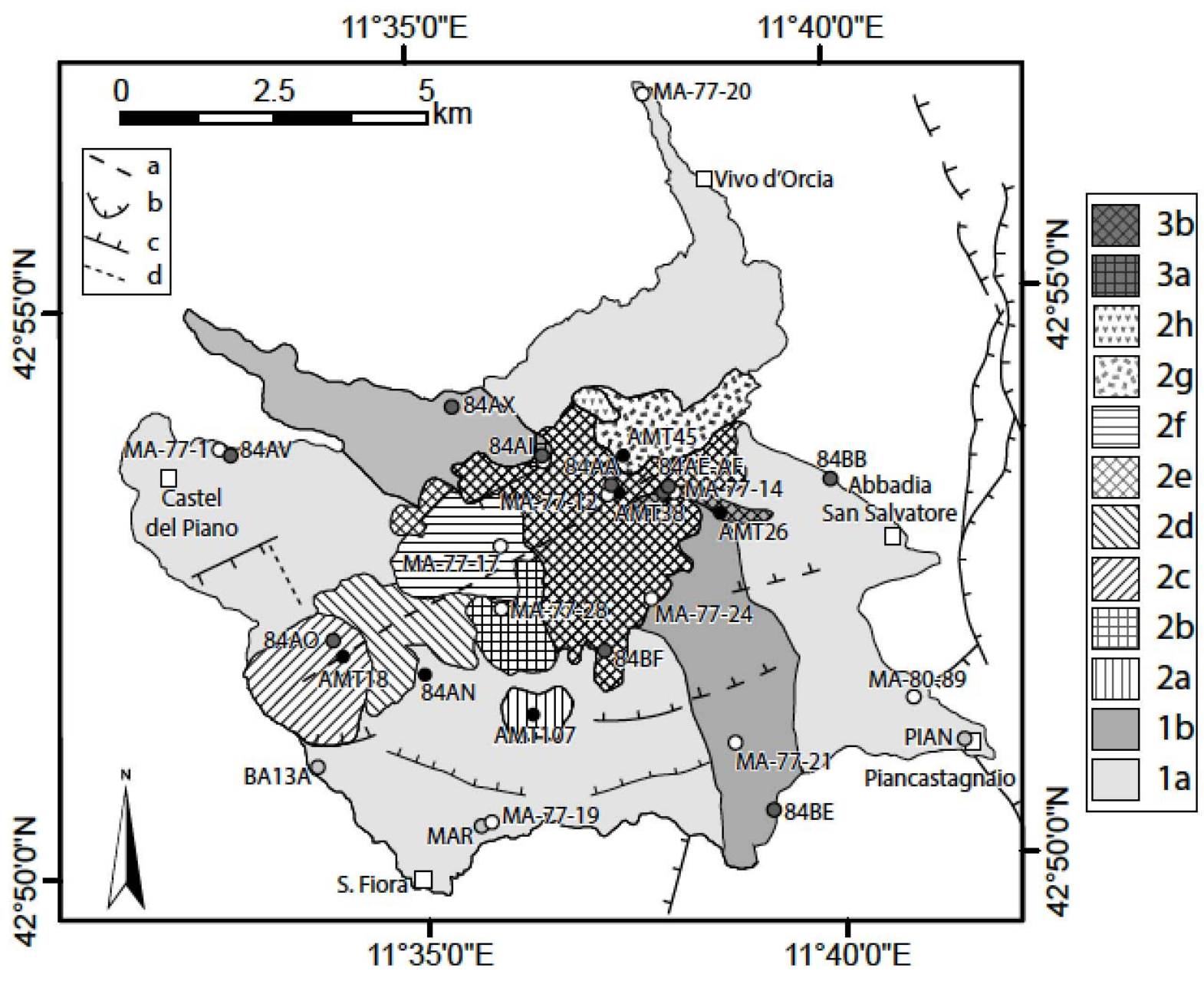
latite (Fig. 100), with a progressive increase of mafic enclaves, passing from trachydacites to the final olivine latite (Fig. 100). The oldest eruption emplaced the "basal trachydacitic complex" (Marroni et al., 2015), which is made of biotite, plagioclase, sanidine, clinopyroxene and orthopyroxene, amphibole, Ti-magnetite and rarely by interstitial quartz (Van Bergen et al., 1983; Van Bergen, 1984; Ferrari et al., 1996; Conticelli et al., 2015b). The apical domes have a slightly bimodal composition with early emplacement of trachytic to latititic lavas (Fig. 100), in the

Fig. 99 - Simplified location map with all samples analysed for dating. 1a-1b) collapsed trachydacitic dome and massive lava flows (1) 2a-f) trachytic domes and massive lava flows; $\mathbf{2 g -}$ h) latitic lava flows; 3a-b) olivine latitic lava flows (from Laurenzi et al., 2015a). 
form of exogenous lava domes and short massive lava flows. The trachytes of the apical domes show porphyritic to strongly porphyritic textures ( $\mathrm{PI}=40-60 \mathrm{vol} . \%$ ) with slightly zoned sanidine megacrysts, beside phenocrysts of zoned plagioclase, clinopyroxene, slightly inversely zoned hypersthene and minor biotite with opacised rim. With respect to trachytes the latites are biotite- and orthopyroxene-free, with rare occurrence of euhedral olivine phenocrysts, dotted by euhedral spinel inclusion, and $\mathrm{Mg}$-rich clinopyroxene. Final lava flows range in composition from olivine-latite to shoshonite (Fig. 99). These lavas have slightly porphyritic textures with phenocrysts of diopsidic to hedembergitic clinopyroxene, reversed zoned plagioclase and minor euhedral highly-forsteritic olivine phenocrysts in a groundmass of sanidine, clinopyroxene, olivine, ilmenite, and apatite.

Fine-grained magmatic enclaves range from porphyritic to aphyric and invariably display chilled margin

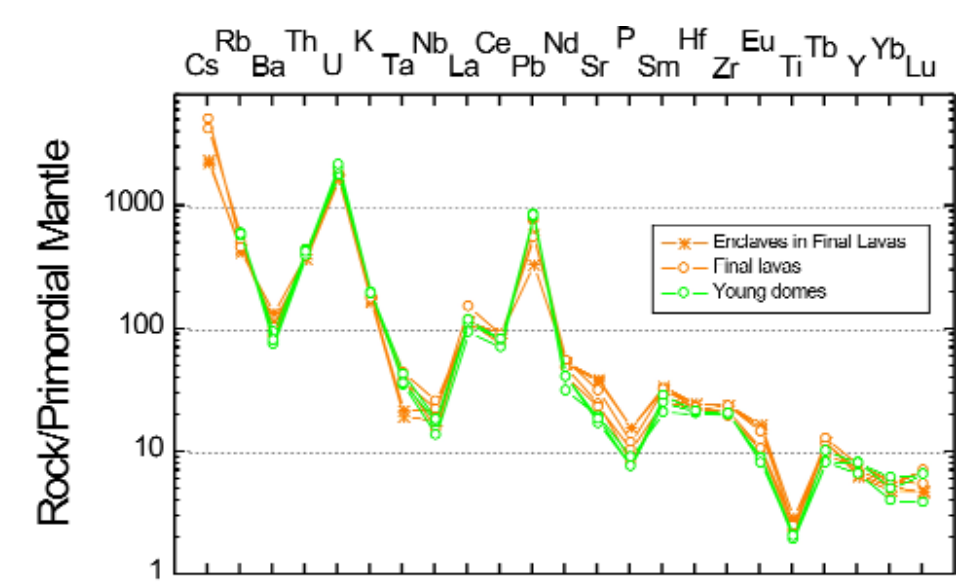
texture, ranging in compositions from trachybasaltic to shoshonitic and latitic. Petrographic and compositional characteristics of finegrained magmatic enclaves suggest that they were molten at the time of inclusion by the host trachytic magma. Their chemical, mineralogical and isotopic characteristics the interaction between different types of magmas prior to the eruption (Ferrari et al., 1996; Cadoux \& Pinti, 2009; Conticelli et al., 2015b).

Conticelli et al. (2015b) have shown that Monte Amiata is a hybrid volcano with magmas generated by mixing/mingling between two magmas of ultimate mantle origin. The resident trachydacitic magma derived by crystal fractionation from a Tuscan-type high-K calcalkaline basaltic-andesitic magma, similar in composition to the last products of the Radicofani Volcano. The refilling magma was a Roman-type one with a silica-undersaturated basanitic composition.

Fig. 100 - TAS (Le Maitre, 2002) and spider (Sun \& McDonough, 1989) diagrams for Monte Amiata volcanic rocks and their enclaves with reported for comparison Radicofani calc-alkaline to shoshonitic rocks and leucite-bearing vulsinian rocks. Note: the field marked with 1 refer to the Radicofani rocks. Data from Ferrari et al. (1996), Conticelli et al. (2011, 2015b), authors' unpublished data. For data used to drawn leucitite Vulsinian rocks see figure 87. 


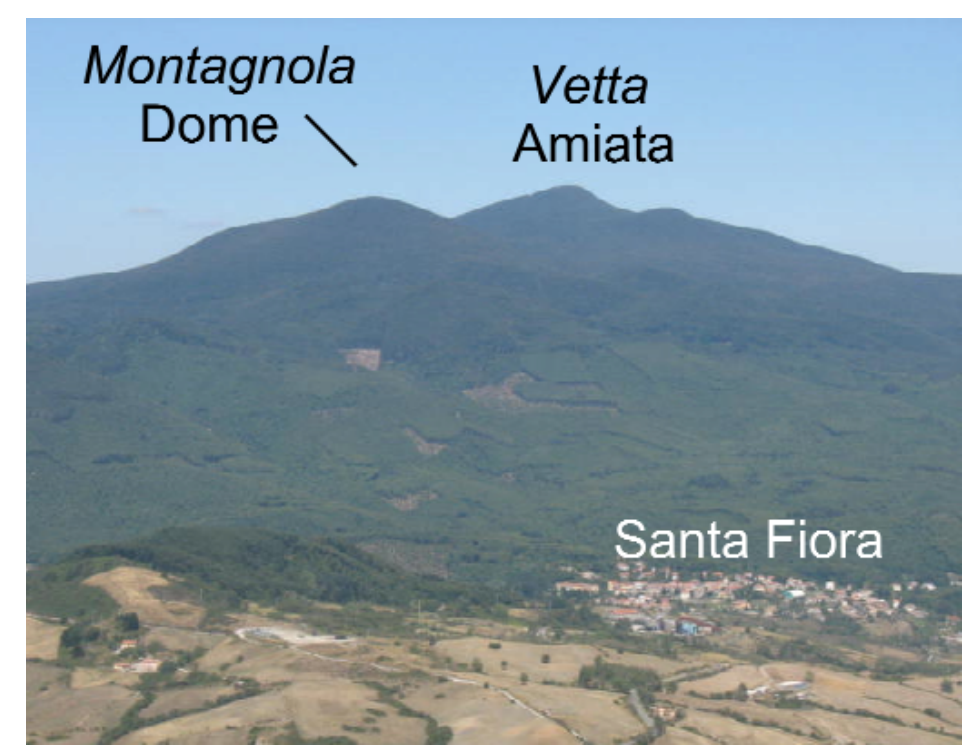

Fig. 101 - View from air of the Monte Amiata Volcano from South, Santa Fiora village is at the foothill of the volcano (Photo: O. Vaselli courtesy).

\section{The Stops of the $5^{\text {th }}$ Day}

You will leave Vulsini driving North along the Cassia road (SS2) passing through the rim of the Bolsena caldera, at San Lorenzo Nuovo, and the northernmost leucite-bearing lavas of Acquapendente (Fig. 102). Then you could visit the Torre Alfina, Radicofani and Monte Amiata volcanoes to observe the type localities of Italian lamproite and shoshonite and the hybrid rocks of Monte Amiata Volcano.
Injection of the newly arrived mafic magma triggered the eruption of the basal trachydacitic complex. The second volcanic episode (apical dome and massive lava flow complex) was characterised by the emplacement of viscous trachytic to latitic magmas in form of domes and short massive lava flows vented from a SSW-NNE eruptive fracture. The composition of erupted magmas is increasingly controlled by the chemical component of the invasive silica-undersaturated magma with respect to the resident one, and the amount and sizes of magmatic enclaves do also increase. Final olivine latitic lavas are characterised by the highest amounts of magmatic enclaves, exclusively belonging to micaceous group, which show the lowest silica-content, and overlaps with the chemical and isotopic composition of Roman-type magmas.

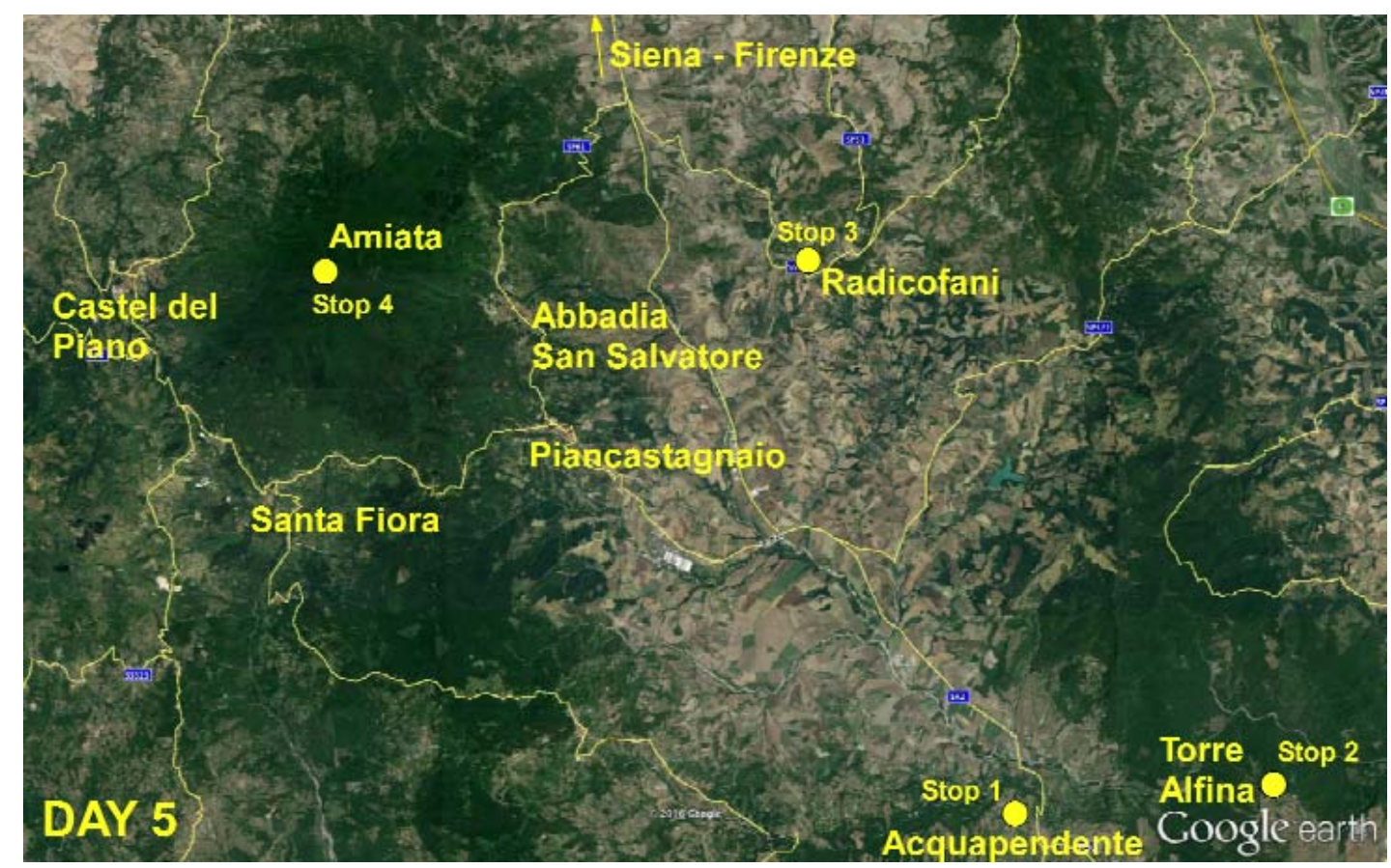

Fig. 102 - Locations of the Stops of the fifth day along the Cassia road in direction of Florence. 


\section{Bolsena lake}

Valentano cinder cones

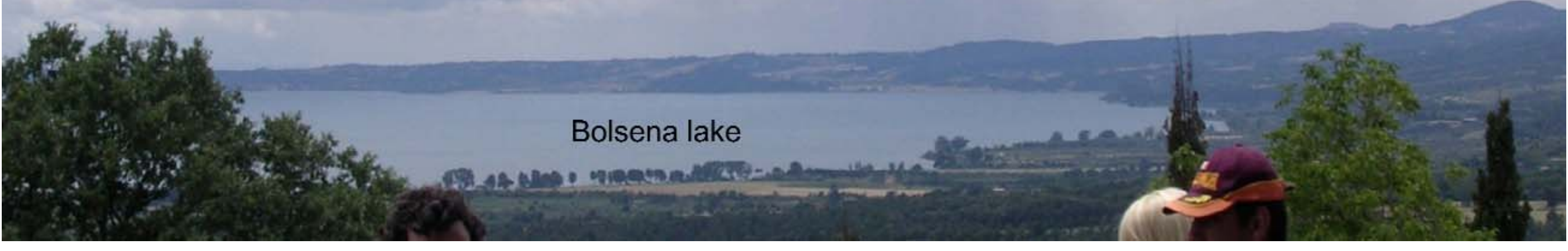

\section{STOP 5.0 (optional): San Lorenzo Nuovo $\left(42^{\circ} 41^{\prime} 02 \mathrm{~N}-11^{\circ} 54^{\prime} 29^{\prime \prime} E\right)$}

This short stop is made along the Cassia road one of the main Italian road (SS2) that follows the track of the homonymous ancient Roman road. The Cassia was an important Roman road starting from the Via Flaminia, near the Milvian Bridge in the immediate vicinity of Rome, and passing through the Roman cities of Baccanae, Sutrium, Vulsinii, Clusium, Arretium, Florentia, Pistoria, and Luca, joining the Via Aurelia at Luni, a small town along the coast of Italy between Pisa and Genoa.

From the terrace at the big turn of the Cassia road, before the southern gate of San Lorenzo Nuovo village, you will have a magnificient view of the Bolsena caldera, filled by the homonymous volcanic lake (Fig. 102).

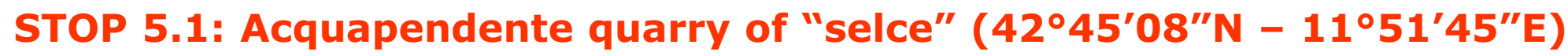

Before the Cassia road descends from the Vulsini plateau into the Paglia river valley, on the left there is a road that apparently runs parallel to main road taking to the old quarry of stones used for road ballast. The rocks here still belong to the Vulsini district and are columnar jointed light gray leucite-bearing phonolite. The leucite megacrysts can reach $4 \mathrm{~cm}$ in size, and it is possible to appreciate on handspecimen the cubic habitus of the crystals with the typical round arranged inclusions of opaques. Leucite has not a vitric appearance but it is milky white testifying incipient transformation to analcime (Conticelli et al., 1986). 
The Torre Alfina Volcano is located a few kms north of the Vulsinian district (Fig. 104), and consists of a few tiny lava flows erupted from a small volcanic centre and a small neck cropping out North of Torre Alfina castle (Fig. 104). Torre Alfina is a monogenetic volcano characterised mainly by lava flows and minor strombolian activity (Conticelli, 1998) resting directly on the sedimentary substratum of the Monte Cetona horst.

The Torre Alfina lava flows were erupted at the top of the hill and flowed partly into the canyon formed by the Paglia river (Fig. 104). Field characteristics indicate that they had low viscosities and some lava tunnels may be recognised in the eastern part of the vent. Two slightly different types of lava, which were emplaced contemporaneously, can be also recognised. They have different colour, vesicularity and porphyritic index. Lava type-A is dark grey, almost aphyric and contains abundant green ultramafic microxenoliths $(2-4 \mathrm{~cm})$, (Conticelli \& Peccerillo, 1990), as well as few lower crustal xenoliths of variable size $(5-10 \mathrm{~cm})$ and nature

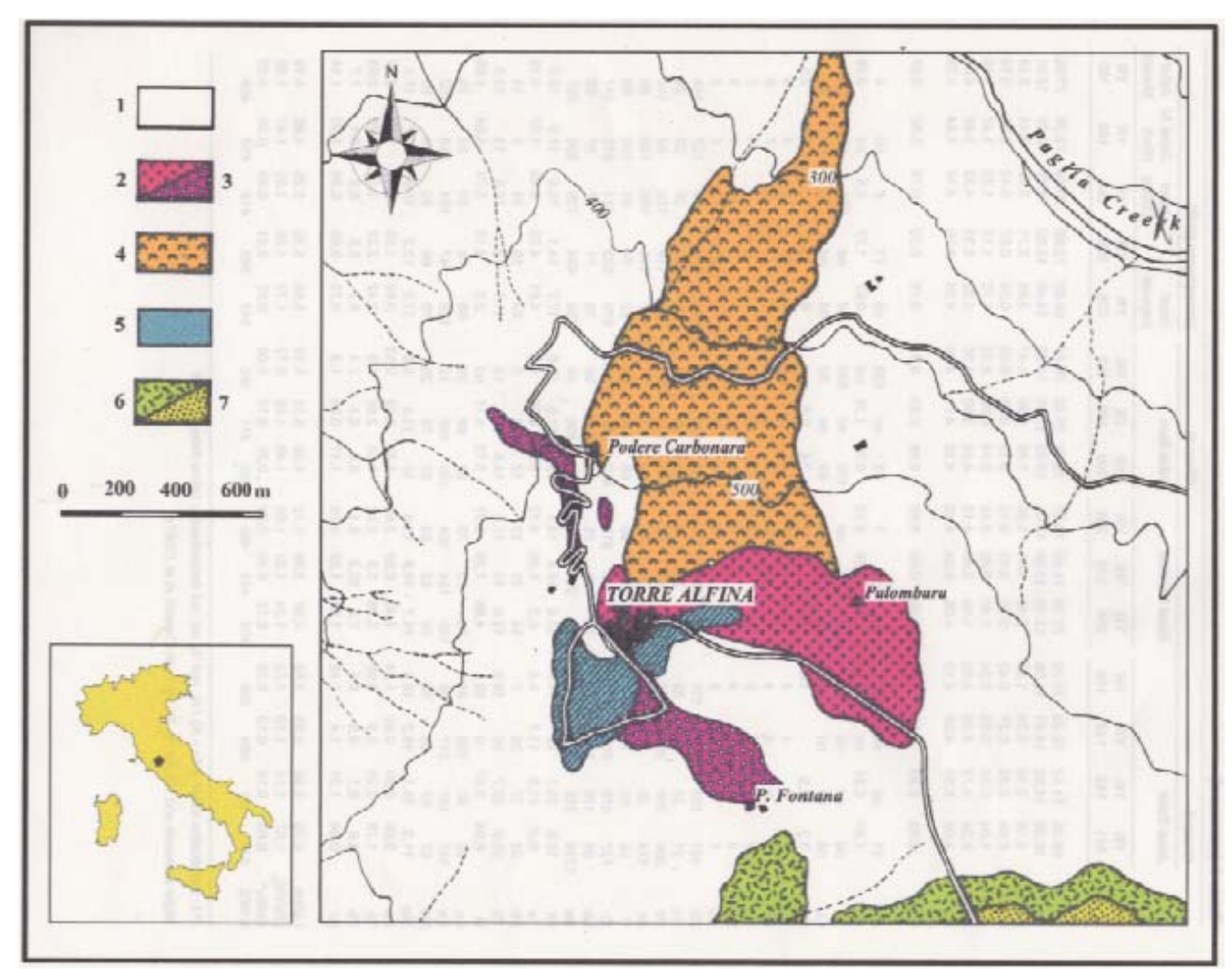

(Orlando et al., 1994). Lava type-B is the most widely represented at Torre Alfina Volcano. It is dark grey to light grey in color, with a variable P.I. and vesicularity, and some flattened vesicles of a few centimeters in length. Type-B lavas contain abundant crustal xenoliths of variable size $(2-30 \mathrm{~cm})$, some large (3-20 cm) magmatic mica-rich inclusions and rare green ultramafic xenoliths. Torre Alfina lavas are leucite free ultrapotassic rocks of lamproitic nature.

Fig. 104 - Geological sketch map of the Torre Alfina Volcano. Legend: 1) Cretaceous carbonaceous and argillaceous sedimentary rocks; 2 ) blocky olivine-latite lava flows, type $\mathrm{B} ; 3$ ) low viscosity olivine-latite lava flows, type $B ; 4)$ low-viscosity olivine-latite lava flows, type A; 5) lapilli and scoriae; 6) leucite-tephrite to leucite-phonolite Vulsini lavas; 7) leucite-phonolite to leucite-trachyte Vulsini pyroclastic rocks. Redrawn after Conticelli (1998). 
The Radicofani hill is a volcanic neck along the Cassia road (Fig. 105). The area around the neck was uprised and deformed by the magma infill dividing the Siena Radicofani basin in two different branches. On the top of the neck is the Radicofani fortress, a Castle of Carolingian origin and documented since 978 AD. The legend tells that this fortress was the headquarters of Ghino di Tacco, an outlaw and a popular hero in thirteenth century Italy. The fortress, occupying the highest point of the hill at $896 \mathrm{~m}$, was restored after the conquest from the Grand Duchy of Tuscany (1560-1567) as the last watchtower at the border with the State of the Pope. Radicofani is a small volcano formed by ca. $90 \mathrm{~m}$-high well-preserved volcanic neck feeding several lava flows and a cinder cone (Fig. 106). The lava flows are scattered around the neck and lie on top of the Pliocene marine sediments. The original volcanic edifice, possibly made up by a cinder cone, has been completely eroded, and

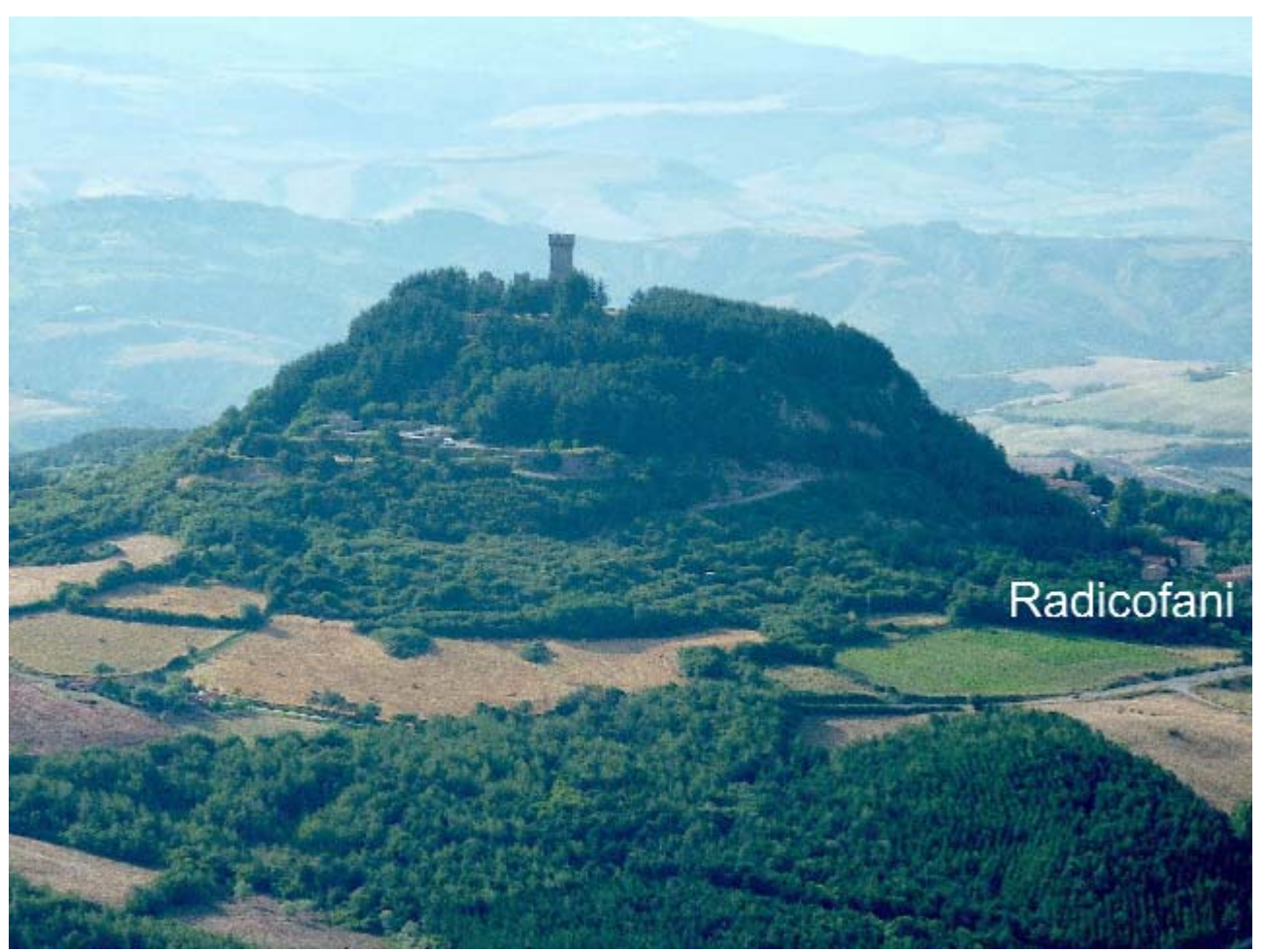

Fig. 105 - Aereal photo of the Radicofani neck with the Ghino di Tacco's castle on its top (O. Vaselli courtesy).

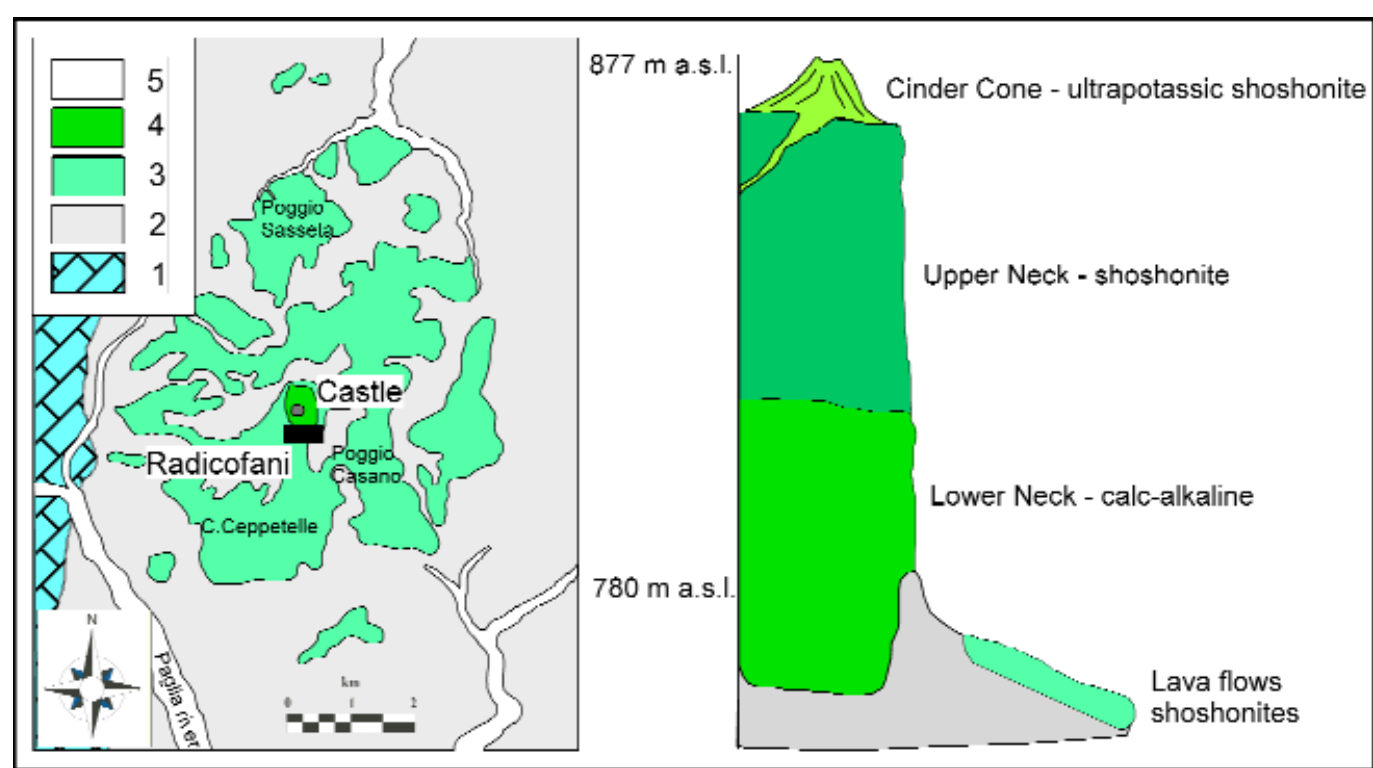

Fig. 106 - Left: geological sketch map of the Radicofani Volcano; right: cross section through the neck, not to scale. Legend: 1) shale and sandstones with interbedded ophiolitic lenses; 2) Pliocene marine shales with minor lenses of sands; 3) isolated blocks of dismembered lava flows and blocky lava flows; 4) volcanic neck with remnants of a scoria cone; 5) Quaternary alluvial deposits, redrawn after Conticelli et al. (2011). 
only a thin layer of red scoriae is preserved on the edge of the top of the neck, just West of the Rocca. The top of the neck is made up of a red vesicular lava that becomes denser and grey to dark grey downward. Columnar jointing is present in the middle and lower portions of the neck in the grey and dark grey aphyric to subaphyric lavas. Oxidised septa dividing the different portions of the neck can also be observed. Volcanic debris (Liotta, 1994) of scattered isolated lava blocks, of decimetre to decametre sizes, are found all around the neck (Fig. 106) for several kilometres. Small lava tongues in their original position are present around the neck at Poggio Sasseta, Case Ceppetelle and Poggio Casano (Fig. 106). Conticelli et al. (2011) divided the Radicofani volcano into three different portions: i) the bottom of the neck, ii) the top of the neck and iii) the lava flows. A few radiometric ages are available for these different portions. A sample from the lava flow of Poggio Sasseta (northbound flow) yielded a ${ }^{40} \mathrm{Ar} /{ }^{39} \mathrm{Ar}$ age of $1.303 \pm 0.005 \mathrm{Ma}$ (D'Orazio et al., 1991). The lava

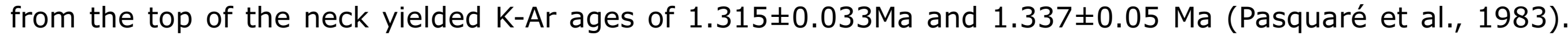
The samples from the bottom of the neck yielded K-Ar ages of $1.08 \pm 0.05 \mathrm{Ma}$ (Barberi et al., 1971) and $1.22 \pm 0.06 \mathrm{Ma}$ (D'Orazio et al., 1991).

The Radicofani volcanic rocks have significant compositional variations (Fig. 97) linked to the different petrographic facies recognised along the neck and within the lava flows. The samples range from basaltic andesite to shoshonite and straddle the boundary between shoshonite and high-K calc-alkaline rocks. Some of the Radicofani rocks, namely the shoshonites of the Poggio Casano lava flows, are ultrapotassic according to the criteria suggested by Carmichael (1967); according to the criteria suggested by Foley et al. (1987) only the middle and lower neck basaltic andesitic samples are not ultrapotassic with most of the other lava flows and top neck shoshonites straddling the divide.

The Radicofani compositional variation along the neck and among the lava flows are though to represent a continuum variation of the condition of partial melting within a veined mantle wedge. The decrease of $\mathrm{K}$ with time, passing from the lava flows to the bottom of the necks is argued to be due to an incremental partial melting of the surrounding mantle with respect to veins (Conticelli et al., 2011). 
You will reach the summit of Monte Amiata Volcano where you can observe in detail the trachytes of the Bellaria and La Vetta coalescent domes and their enclaves. In addition, you will observe the increase of mafic enclaves approaching the fracture in western flank of the La Vetta dome from where the Ermeta olivine latitic final lavas was erupted (Fig. 98).

The occurrence of magmatic enclaves, beside metasedimentary xenoliths, in the rocks of the Monte Amiata Volcano is one of the most striking features providing information of the genesis of Amiata magmas (van Bergen, 1984; Ferrari et al., 1996; Conticelli et al., 2015b). Magmatic rounded enclaves range from centimetric to decimetric in size, have ellipsoidal shapes, with cuspidate margins convex toward the host, and sometimes contain metasedimentary or magmatic inclusion themselves (Ferrari et al., 1996). Fine-grained magmatic enclaves range from porphyritic to aphyric with chilled margins. All these characteristics indicate that they

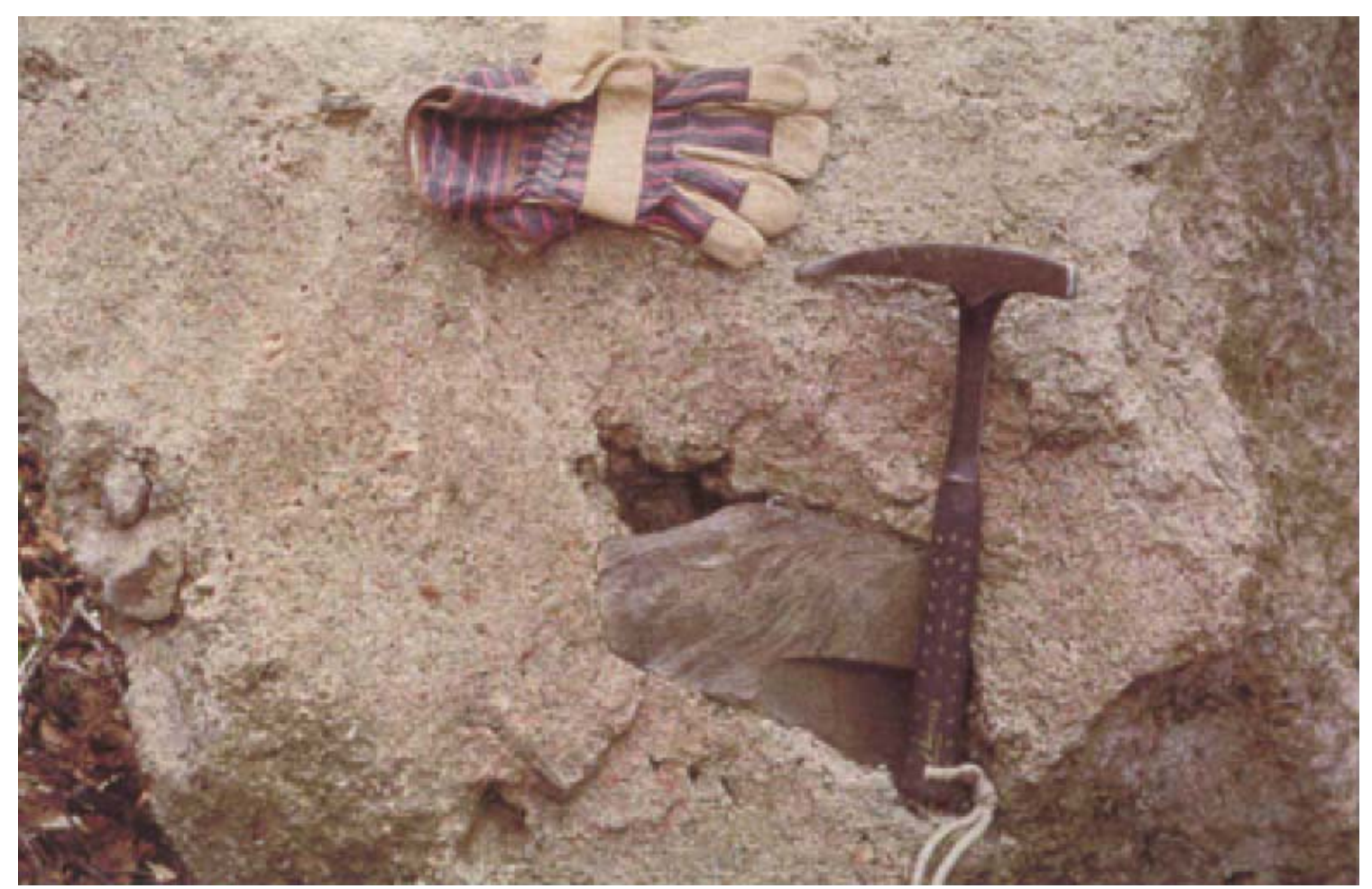

DOI: 10.3301/GFT.2017.01 were molten when enclosed by the Amiata resident magma. These magmatic enclaves can be divided in three broad sub-groups: i) micaceus micro-porphyritic (type-I), ii) subporphyritic olivine-bearing, (type-II), and iii) porphyritic plagioclase-bearing (type-III). Type-III are most abundant in the earlier Amiata rocks, whilst type-I are almost exclusively found in the final olivine latites (Conticelli et al., 2015b)

Fig. 107 - rounded micro-granular magmatic enclave in Amiata volcanic rock (Photo: S. Conticelli). 


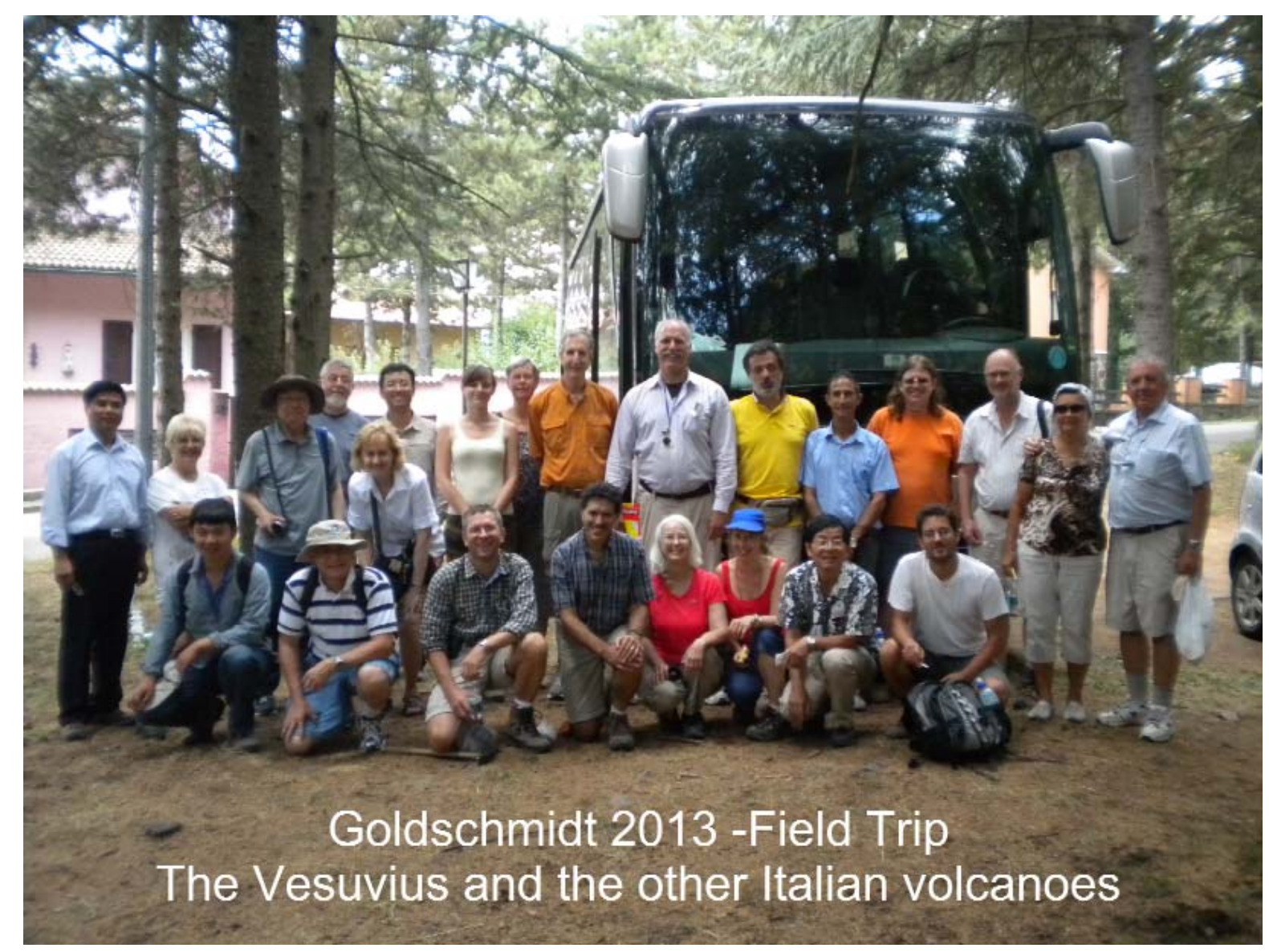

ACKNOWLEDGEMENTS

This Field Trip guide was originally written and offered to the participants during the pre-meeting events of the Goldschmidt 2013. The authors wish to thank participants: Charlotte Brunner, Linda Campbell, Roger Dixon, James Donahoe, Rona Donahoe, Denton Ebel, Ying Jifeng, Felix Kaminsky, Larissa Kaminskaia, Sven Åke Larsson, Aivo Lepland, Katarzyna Lisowiec, Peter Michael, Takashi Ohsumi, Jiansheng Qiu, James Roberts, Alan Shiller, Ewa Slaby, Eva-Lena Tullborg, Quan Wan, Yi Xiao, Zhou Xinhua, Zhao Yongwei for their feedbacks during the field trip. Official review by Cliff Shaw greatly helped to improve the original version of this guide. A warmful thank is dedicated to the memory of Gloria Ciarapica, the former Editor in Chief of the Journal, who carefully handled the manuscript of this Field Trip guide.

Financial support for final editing provided by PRIN2015 grant \# 20158A9CBM issued to S.C.. 
Acocella V. \& Funiciello R. (2006) - Transverse systems along the extensional Tyrrhenian margin of central Italy and their influence on volcanism. Tectonics 25, TC2003, 24 pp. doi: 10.1029/2005TC001845.

Acocella V., Porreca M., Neri M., Massimi E. \& Mattei M. (2006) - Propagation of dikes at Vesuvio (Italy) and the effect of Mt. Somma, Geophys. Res. Lett. 33, L08301, 4 pp. doi:10.1029/2005GL025590.

Ammannati E., Jacob D.E., Avanzinelli R., Foley S.F. \& Conticelli S. (2016) - Low Ni olivine in silica-undersaturated ultrapotassic igneous rocks evidence for carbonate metasomatism in the mantle. Earth Planet. Sci. Lett. 444, 64-74.

Anderson H., Jackson J. (1987) - Active tectonics of the Adriatic Region. Geophys. J. Royal Astron. Soc. 91,937 - 983.

Andronico D. \& Cioni R. (2002) - Contrasting styles of Mount Vesuvius activity in the period between the Avellino and Pompeii Plinian eruptions, and some implications for assessment of future hazards. Bull. Volcanol. 64, 372-391.

Anzidei M., Carapezza M.L., Esposito A., Giordano G., Tarchini L. \& Lelli M. (2008) - The Albano Maar Lake High resolution bathymetry and dissolved CO2 budget (Colli Albani District, Italy): constrains to hazard evaluation, J. Volcanol. Geotherm. Res. $151,258-268$.

Appleton J.D. (1972) - Petrogenesis of Potassium rich lavas from the Roccamonfina Volcano, Roman Region Italy. J. Petrol. 13 , $425-456$. Arculus R.J. (2003) - Use and Abuse of the Terms Calcalkaline and Calcalkalic. J. Petrol. 44, 929-935.

Arienzo I., Moretti R., Civetta L., Orsi G. \& Papale P. (2010) - The feeding system of Agnano-Monte Spina eruption (Campi Flegrei, Italy): Dragging the past into present activity and future scenarios. Chem. Geol. 270, 135-147.

Armienti P., Barberi F., Bizojard H., Clocchiatti R., Innocenti F. \& Metrich N. (1983) - The Phlegraean Fields: magma evolution within a shallow chamber. J. Volcanol. Geoth. Res. 17, 289-311.

Arrighi S., Principe C. \& Rosi M. (2001) - Violent strombolian and subplinian eruptions at Vesuvius during post-1631 activity. Bull. Volcanol. 63, 126-150.

Asmerom Y. (1999) - Th-U fractionation and mantle structure. Earth Planet. Sci. Lett. 166, $163-175$.

Asmerom Y. \& Edwards R.L. (1995) - U-series isotope evidence for the origin of continental basalts. Earth Planet. Sci. Lett $134,1-7$.

Asmerom Y., Cheng H., Thomas R., Hirschmann M. \& Edwards R.L. (2000) - Melting of the Earth's Lithospheric mantle inferred from Protactinium-Thorium-Uranium isotopic data. Nature 406, 293-296.

Auger E., Gasparini P., Virieux J. \& Zollo A. (2001) - Seismic Evidence of an Extended Magmatic Sill Under Mt. Vesuvius. Science 9918. Aurisicchio C., Federico M. \& Gianfagna A. (1988) - Clinopyroxene chemistry of the high-potassium suite from the Alban Hills, Italy. Mineral. Petrol. 39, 1-19.

Avanzinelli R., Elliott T., Tommasini S. \& Conticelli S. (2008) - Constraints on the genesis of the potassium-rich Italian volcanics from U/Th disequilibrium. J. Petrol. 49. 195-223.

Avanzinelli R., Lustrino M., Mattei M., Melluso L. \& Conticelli S. (2009) - Potassic and ultrapotassic magmatism in the circumTyrrhenian region: the role of carbonated pelitic vs. pelitic sediment recycling at destructive plate margin. Lithos, $113,213-227$.

Avanzinelli R., Sapienza G.T. \& Conticelli S. (2012) - The Cretaceous to Paleogene within-plate magmatism of Pachino-Capo Passero (southeastern Sicily) and Adria (La Queglia and Pietre Nere, southern Italy): geochemical and isotopic evidence against a plume-related origin of circum-Mediterranean magmas. Europ. J. Mineral. 24, 73-96. 
Avanzinelli R., Braschi E., Marchionni S. \& Bindi L. (2014) - Mantle melting in within-plate continental settings: Sr-Nd-Pb and U-series isotope constraints in alkali basalts from the Sicily Channel (Pantelleria and Linosa Islands, Southern Italy). Lithos 188, $113-129$.

Ayuso R.A., De Vivo B., Rolandi G., Seal R.R. II \& Paone A. (1998) - Geochemical and isotopic (Nd-Pb-Sr-O) variations bearing on the genesis of volcanic rocks from Vesuvius, Italy. J. Volcanol. Geotherm. Res. 82, 53-78.

Ballini A., Barberi F., Laurenzi M.A., Mezzetti F. \& Villa I.M. (1989a) - Nuovi dati sulla stratigrafia del vulcano di roccamonfina. Bollettino Gruppo Nazionale Vulcanologia 5, 533-555.

Ballini A., Frullani A. \& Mezzetti F. (1989b) - La formazione piroclastica del tufo trachitico bianco del vulcano di Roccamonfina. Bollettino Gruppo Nazionale Vulcanologia 5, 557-574.

Barberi F., Borsi S., Ferrara G. \& Innocenti F. (1967) - Contributo alla conoscenza vulcanologica e magmatologica delle Isole dell'Archipelago Pontino. Mem. Soc. Geol. Ital. 6, 581-606.

Barberi F. \& Leoni L. (1980) - Metamorphic carbonate ejecta from Vesuvius plinian eruptions: evidence of the occurrence of shallow magma chambers. Bull. Volcanol. 43, 107-120.

Barberi F., Corrado G., Innocenti F. \& Luongo G. (1984) - Phlegraean Fields 1982-1984: Brief chronicle of a volcano emergency in a densely populated area. Bull. Volcanol., 47, 175-185.

Barberi F., Buonasorte G., Cioni R., Fiordelisi A., Foresi L., Iaccarino S., Laurenzi M.A., Sbrana A., Vernia L. \& Villa I.M. (1994) Plio-Pleistocene geological evolution of the geothermal area of Tuscany and Latium. Mem. Descrittive Carta Geologica d'Italia 49, 77-134.

Barchi M., Amato A., Cippitelli G., Merlini S. \& Montone P. (2007) - Extensional tectonics and seismicity in the axial zone of the Southern Apennines. Boll. Soc. Geol. Ital., Special volume 7, 47-56.

Bartole R. (1995) - The North Tyrrhenian-Northern Apennines post-collisional system: constraints for a geodynamic model. Terra Nova 7, 7-30.

Barton M., Varekamp J.C. \& van Bergen M.J. (1982) - Complex zoning of clinopyroxenes in the lavas of vulsini, latium, Italy: Evidence for magma mixing. J. Volcanol. Geoth. Res. 14, 361-388.

Basilone P. \& Civetta L. (1975) - Datazione K/Ar dell'attività vulcanica dei Monti Ernici (Latina). Rend. Soc. It. Mineral. Petrol., 31 , $175-179$.

Battaglia M., Troise C., Obrizzo F., Pingue F. \& De Natale G. (2006) - Evidence for fluid migration as the source of deformation at Campi Flegrei caldera (Italy). Geophys. Res. Lett., 33 (L01307-10).

Bear A.N., Cas R.A.F., Giordano G. (2009a) - Variations in eruptive style and depositional processes associated with explosive, phonolitic composition, caldera-forming eruptions: The 151 ka Sutri eruption, Vico Caldera, central Italy. J. Volcanol. Geotherm. Res. 184, 225-255.

Bear A.N., Cas R.A.F., Giordano G. (2009b) - The implications of spatter, pumice and lithic clast rich proximal co-ignimbrite lag breccias on the dynamics of caldera forming eruptions: The 151 ka Sutri eruption, Vico Volcano, Central Italy. J. Volcanol. Geotherm. Res. 181, 1-24.

Beccaluva L., Gabbianelli G., Lucchini F., Rossi P.L. \& Savelli C. (1985) - Petrology and K/Ar ages of volcanics dredged from the Eolian Seamounts: implications for geodynamic evolution of the southern Tyrrhenian basin. Earth Planet. Sci. Lett. 74, $187-208$.

Beccaluva L., Di Girolamo P., Morra V. \& Siena F. (1990) - Phlegrean fields volcanism revisited: A critical re-examination of deep eruptive systems and magma evolutionary processes. N. Jb. Geol. Paläont. Mh., 257-271. 
Beccaluva L., Di Girolamo P. \& Serri G. (1991) - Petrogenesis and tectonic setting of the Roman Volcanic Province, Italy. Lithos $26,191-221$.

Beccaluva L., Coltorti M., Di Girolamo P., Melluso L., Milani L., Morra V. \& Siena F. (2002) - Petrogenesis and evolution of Mt.Vulture alkaline volcanism (Southern Italy). Mineral. Petrol. 74, 277-297.

Beccaluva L., Bianchini G., Mameli P. \& Natali C. (2013) - Miocene shoshonite volcanism in Sardinia: Implications for magma sources and geodynamic evolution of the central-western Mediterranean. Lithos 180-181, $128-137$.

Belkin H.E. \& De Vivo B. (1993) - Fluid inclusion studies of ejected nodules from plinian eruptions of Mt. Somma-Vesuvius. J. Volcanol. Geotherm. Res. 58, 89-100.

Bell K., Castorina F., Lavecchia G., Rosatelli G. \& Stoppa F. - (2004) - Is there a mantle plume beneath Italy ? EOS 85, $541-547$. Bell K., Lavecchia G. \& Rosatelli G. (2013) - Cenozoic Italian magmatism: isotope constraints for possible plume-related activity. J. South Am Earth Sci. 41, 22-40.

Bellucci F., Lirer L. \& Munno R. (1999) - Geology of Ponza, Ventotene and Santo Stefano. Acta Vulcanologica 11, $197-222$.

Bertagnini A. \& Sbrana A. (1986) - Il vulcano di Vico: stratigrafia del complesso vulcanico e sequenze eruttive delle formazioni piroclastiche. Mem. Soc. Geol. Itali. 35, 699-713.

Bertagnini A., Landi P., Rosi M. \& Vigliargio A. (1998) - The Pomici di Base plinian eruption of Somma-Vesuvius. J. Volcanol. Geotherm. Res. 83 (3-4), 219-239.

Bianchini G., Beccaluva L. \& Siena F. (2008) - Post-collisional and intraplate Cenozoic volcanism in the rifted Apennines/Adriatic domain. Lithos 101, 125-140.

Bigazzi G., Bonadonna F.P., Ghezzo C., Giuliani O., Radicati di Brozolo F. \& Rita F. (1981) - Geochronological study of the Monte Amiata lavas (Central Italy). Bull. Volcanol. 44(3), 455-465.

Bindi L., Cellai D., Melluso L., Conticelli S., Morra V. \& Menchetti S. (1999) - Crystal Chemistry of Clinopyroxene from Alkaline undersaturated rocks of the Monte Vulture Volcano, Italy. Lithos 46, 259-274.

Boari E. \& Conticelli S. (2007) - Mineralogy and Petrology of Mg-rich calc-alkalic, potassic, and ultrapotassic associated rocks: the Middle Latin Valley monogenetic volcanoes, Roman Magmatic Province, Southern Italy. Canad. Mineral. 45, $1443-1469$.

Boari E., Avanzinelli R., Melluso L., Giordano G., Mattei M., Morra V. \& Conticelli S. (2009b) - Isotope geochemistry (Sr-Nd-Pb) and petrogenesis of leucite-bearing volcanic rocks from "Colli Albani" volcano, Roman Magmatic Province, Central Italy: inferences on volcano evolution and magma genesis. Bull. Volcanol. 71, 977-1005.

Boari E., Tommasini S., Laurenzi M.A. \& Conticelli S. (2009a) - Transition from ultrapotassic kamafugitic to sub-alkaline magmas: $\mathrm{Sr}, \mathrm{Nd}$, and $\mathrm{Pb}$ isotope, trace element and $40 \mathrm{Ar}-39 \mathrm{Ar}$ age data from the Middle Latin Valley volcanic field, Roman Magmatic Province, Central Italy. J. Petrol. 50, 1327-1357.

Bodnar R., Cannatelli C., De Vivo B., Lima A., Belkin H. \& Milia A. (2007) - Quantitative model for magma degassing and ground deformation (bradyseism) at Campi Flegrei, Italy. Geology, 35, 791-794.

Bonadonna C., Ernst G.G.J. \& Sparks R.S.J. (1998) - Thickness variations and volume estimates of tephra fall deposits: the importance of particle Reynolds number. J. Volcanol. Geotherm. Res. 81, 173-187.

Borghetti G., Sbrana A. \& Sollevanti F. (1981) - Vulcano-Tettonica dell'Area dei Monti Cimini e rapporti Cronologici tra Vulcanismo Cimino e Vicano. Rendiconti Soc. Geol. Ital., 4, 253-254. 
Borsi S. (1967) - Contributo alla conoscenza dell'età e dell'origine magmatica del vulcanismo dell'Isola di Capraia (Arcipelago Toscano). Atti Soc. Tosc. Sci. Nat., Mem, 1967.

Borsi S., Ferrara G. \& Tongiorgi E. (1967) - Determinazione con il metodo K/Ar delle età delle rocce magmatiche della Toscana. Boll. Soc. Geol. Ital., 86, 403-410.

Brancaccio L., Cinque A., Romano P., Rosskopf C., Russo F., Santangelo N. \& Santo A. (1991) - Geomorphology and neotectonic evolution of a sector of a Tyrrhenian Flank of the Southern Apennines (Regions of Naples, Italy). Z. Geomorph., 82, 47-58.

Brocchini D., Di Battistini G.D., Laurenzi M.A., Vernia L., Bargossi G.M. (2000) - New 40Ar/39Ar datings on the southeastern sector of the Vulsinian Volcanic District (Central Italy). Boll. Soc. Geol. Ital. 119, 113-120.

Brocchini D., Principe C., Castradori D., Laurenzi M.A. \& Gorla L. (2001) - Quaternary evolution of the southern sector of the Campanian Plain and early Somma Vesuvius activity: insights from the Trecase 1 well. Mineral. Petrol. 73, 67-92.

Burton M.R., Sawyer G.M. \& Granieri D. (2013) - Deep carbon emissions from volcanoes. Rev. Mineral. Geochem. 75 , 323354.

Cadoux A. \& Pinti D.L. (2009) - Hybrid character and pre-eruptive events of Mt Amiata volcano (Italy) inferred from geochronological, petro-geochemical and isotopic data. J. Volcanol. Geoth. Res. 179, 169-190.

Cadoux A., Pinti D.L., Aznar C., Chiesa S. \& Gillot P.-Y. (2005) - New chronological and geochemical constraints on the genesis and geological evolution of Ponza and Palmarola Volcanic Islands (Tyrrhenian Sea, Italy). Lithos 81, $121-151$.

Capitanio F., Larocca F. \& Improta S. (2004) - High-temperature rapid pyrometamorphism induced by a charcoal pit burning: The case of Ricetto, central Italy. Intern. J. Earth Sci. 93, 107-118.

Carapezza M.L., Badalamenti B., Cavarra L. \& Scalzo A. (2003) - Gas hazard assessment in a densely inhabited area of Colli Albani volcano (Cava dei Selci, Roma). J. Volcanol. Geotherm. Res., 123: 81-94.

Carapezza M.L. \& Tarchini L. (2007) - Magmatic degassing of the Alban Hills volcano (Rome, Italy): geochemical evidence from accidental gas emission from shallow pressurized aquifers, J. Volcanol. Geotherm. Res., 165, 5-16

Carapezza M.L, Barberi F., Tarchini L., Ranaldi M. \& Ricci T. (2010) - Volcanic hazard of Colli Albani. In: Funiciello, R., Giordano, G. (eds) The Colli Albani Volcano. Special Publication of IAVCEI, 3. The Geological Society, London.

Carlson R.W., Esperança S. \& Svisero D.P. (1996) - Chemical and Os isotopic study of Cretaceous potassic rocks from Southern Brazil. Contrib. Mineral. Petrol. 125, 393-405.

Carlson R.W., Pearson D.G. \& James. D.E. (2005) - Physical, chemical and chronological characteristics of continental mantle. Rev. Geophys. 43, RG1001, 24 pp.

Carmichael I.S.E. (1967) - The mineralogy and Petrology of volcanic rocks from Leucite Hills Wyoming. Contrib. Mineral. Petrol. $15,24-66$.

Carmignani L., Carosi A., Di Pisa A., Gattiglio M., Musumeci G., Oggiano G. \& Pertusati P.C. (1994) - The Hercynian chain in Sardinia, Italy). Geodin. Acta 7, 31-47.

Carminati E., Negredo A.M., Valera J.L. \& Doglioni C. (2005) - Subduction-related intermediate-depth and deep seismicity in Italy: insights from thermal and rheological modelling. Phys. Earth Planet. Interiors 149, 65-79.

Carraro F. \& Ferrara G. (1978) - Alpine tonalite at Miagliano, Biella (zone diorite-kinzigitica). Schweiz. Mineral. Petrograp. Mitt., 48. $75-80$.

Carta S., Figari R., Sartoris G., Sassi E. \& Scandone R. (1981) - A statistical model for Vesuvius and its volcanological implications. Bull. Volcanol. 44, 129-151. 
Cassignol C. \& Gillot P.Y. (1982) - Range and effectiveness of unspiked potassium-argon dating: experimental groundwork and applications. In: "Numerical Dating in Stratigraphy", (Odin G.S. Ed.), John Wiley \& Sons, New York, $159-179$.

Castorina F., Stoppa F., Cundari A. \& Barbieri M. (2000) - An enriched mantle source for Italy's melilitite-carbonatite association as inferred by its Nd-Sr isotope signature. Mineral. Mag. 64, 625-639.

Cellai D., Conticelli S. \& Diella V. (1993) - Perrierite-chevkinite in igneous ultrapotassic rocks from Central Italy, chemical data and their petrological significence. Periodico Mineralogia 62, 57-66.

Cellai D., Conticelli S. \& Menchetti S. (1994) - Crystal-chemistry of clinopyroxenes in Italian Lamproites and Kamafugites, Implications on their genesis. Contrib. Mineral. Petrol. 116, 301-315.

Chelazzi L., Bindi L., Olmi F., Peccerillo A., Menchetti S. \& Conticelli S. (2006) - A lamproitic component in the high-K calc-alkaline volcanic rocks of the Capraia Island, Tuscan Magmatic Province: evidence from clinopyroxene crystal chemical data. Periodico Mineralogia 75, 75-94.

Chen B., Jahn B.M. \& Suzuki K. (2013) - Petrological and Nd-Sr-Os isotopic constraints on the origin of high-Mg adakitic rocks from the North China Craton: Tectonic implications. Geology 41, 91-94.

Chiarabba C., Malagnini L. \& Amato A. (1994) - Three dimensional velocity structure and earthquake relocation. In: The Alban Hills volcano, Central Italy. Bull. Seis. Soc. Amer., 84: 295-306

Chiarabba C., Amato A. \& Delaney P.T. (1997) - Crustal structure, evolution and volcanic unrest of the Alban Hills, Central Italy. Bull. Volcanol., 59: 161-170.

Chiarabba C., Giordano G., Mattei M. \& Funiciello R. (2010) - The 3D structure of the Colli Albani volcano. In: Funiciello R. \& Giordano G. (eds). The Colli Albani Volcano. Special Publication of IAVCEI, 3. The Geological Society, London, $29-41$.

Chiodini G., Frondini F., Magro G., Marini L., Panichi C., Raco B. \& Russo M. (1997) - Chemical and isotopic variations of Bocca Grande fumarole (Solfatara volcano, Phlegrean Fields). Acta Vulcanologica 8, 228-232.

Chiodini G., Cardellini C., Amato A., Boschi E., Caliro S., Frondini F. \& Ventura G. (2004) - Carbon dioxide Earth degassing and seismogenesis in central and southern Italy. Geophys. Res. Lett. 31, L07615. doi:10.1029/2004GL019480

Chiodini G., Caliro S., De Martino P., Avino R. \& Gherardi F. (2012) - Early signals of new volcanic unrest at Campi Flegrei caldera? Insights from geochemical data and physical simulations. Geology 40, 943-946.

Cifelli F., Mattei M. \& Rossetti F. (2007) - Tectonic evolution of arcuate mountain belts on top of a retreating subduction slab: The example of the Calabrian Arc. J.Geophys. Res. 112, B09101, doi: 10.1029/2006JB004848.

Cimarelli C. \& De Rita D. (2006a) - Relatively rapid emplacement of dome-forming magma inferred from strain analyses: the case of the acid Latian dome complexes (Central Italy). J. Volcanol. Geoth. Res. 158, 106-116.

Cimarelli C. \& De Rita D. (2006b) - Structural evolution of the Pleistocene Cimini trachytic volcanic complex (Central Italy). Bull. Volcanol. 68, 538-548.

Cinque A., Patacca E., Scandone P. \& Tozzi M. (1993) - Quaternary kinematic evolution of the Southern Apennines. Relationship between surface geological features and deep lithospheric structures. Annali Geofisica 36, $249-260$.

Cioni R., Laurenzi M.A., Sbrana A. \& Villa I.M. (1993) - 40Ar/39Ar chronostratigraphy of the initial activity in the Sabatini volcanic complex (Italy). Boll. Soc. Geol. Ital. 112, 251-263. 
Cioni R. (2000) - Volatile content and degassing processes in the AD 79 magma chamber at Vesuvius (Italy). Contrib. Mineral. Petrol. 140, 40-54.

Cioni R., Civetta L., Marianelli P., Métrich N., Santacroce R. \& Sbrana A. (1995) - Compositional layering and syneruptive mixing of a periodically refilled shallow magma chamber: the AD 79 Plinian eruption of Vesuvius. J. Petrol. 36, $739-776$.

Cioni R., Marianelli P. \& Santacroce R. (1997) - Thermal and compositional evolution of the shallow magma chambers of Vesuvius: Evidence from pyroxene phenocrysts and melt inclusions. J. Geophys. Res. 103, 18277-18294.

Cioni R., Marianelli P. \& Santacroce R. (1999a) - Temperature of Vesuvius magmas. Geology 27, $443-446$.

Cioni R., Santacroce R. \& Sbrana A. (1999b) - Pyroclastic deposits as a guide for reconstructing the multi-stage evolution of the Somma-Vesuvius caldera. Bull. Volcanol. 60, 207-222.

Cioni R., Sulpizio R. \& Garruccio N. (2003) - Variability of the eruption dynamics during a Subplinian event: the Greenish Pumice eruption of Somma-Vesuvius (Italy). J. Volcanol. Geotherm. Res. 124, 89-114.

Cioni R., Bertagnini A., Santacroce R. \& Andronico D. (2008) - Explosive activity and eruption scenarios at Somma-Vesuvius (Italy): Towards a new classification scheme. J. Volcanol. Geoth. Res. 178, 331-346

Cipollari P. \& Cosentino D. (1995) - Miocene unconformities in the central Apennines: geodynamic significance and sedimentary basin evolution. Tectonophysics 252, 375-389.

Civetta L., Orsi G., Scandone P. \& Pece R. (1978) - Eastward migration of the Tuscan Anatectic magmatism due to anticlockwise rotation of the Apennines. Nature 276, 604-606.

Civetta L., Innocenti F., Manetti P., Peccerillo A., \& Poli G. (1981) - Geochemical characteristics of potassic volcanics from Mt. Ernici (Southern, Latium, Italy). Contrib. Mineral. Petrol. 78, 37-47.

Civetta L., Galati R., Santacroce R. (1991a) - Magma mixing and convective compositional layering within the Vesuvius magma chamber. Bull. Volcanol., 53, 287.

Civetta L., Del Carmine P., Manetti P., Peccerillo A. \& Poli G. (1984) - Petrology, geochemistry and Sr-isotope characteristics of lavas from the area of Commenda (Mts. Vulsini, Italy). Bull. Volcanol. 47, 581-595.

Civetta L., Carluccio E., Innocenti F., Sbrana A. \& Taddeucci G. (1991b) - Magma chambre evolution under the Phlegrean fields during the last $10 \mathrm{ka}$ : trace element and isotop data. Europ. J. Mineral. 3, 415-428.

Civetta L. \& Santacroce R. (1992) - Steady-state magma supply in the last 3,400 years of Vesuvius. Acta Vulcanol. 2, $147-159$.

Civetta L., Orsi G., Pappalardo L., Fisher R., Heiken G. \& Ort M. (1997) - Geochemical zoning, mingling, eruptive dynamics and depositional processes - The Campanian Ignimbrite, Campi Flegrei caldera, Italy. J. Volcanol. Geoth. Res., 75, $183-197$.

Class C., Miller D.M., Goldstein S.L. \& Langmuir C.H. (2000) - Distinguishing nelt and fluid subduction components in Umnak volcanics, Aleutinian arc. Geochemistry Geophysics Geosystem 1: paper \# $1999 \mathrm{GC000010.}$

Cole P.D., Guest J.E., Duncan A.M., Chester D.K. \& Bianchi R. (1992) - Post-collapse volcanic history of calderas on a composite volcano: an example from Roccamonfina, Southern Italy. Bull. Volcanol. 54, 504-520.

Cole P.D. \& Scarpati C. (1993) - A facies interpretation of the eruption and emplacement mechanisms of the upper part of the Neapolitan Yellow Tuff, Campi Flegrei, southern Italy. Bull. Volcanol. 55, 311-326.

Cole P.D., Guest J.E. \& Duncan A.M. (1993) - The emplacement of intermediate volume ignimbrite: a case study from Roccamonfina volcano, Southern Italy. Bull. Volcanol. 55, 467-480. 
Collettini C., De Paola N., Holdsworth R.E. \& Barchi M.R. (2006) - The development and behaviour of low-angle normal faults during Cenozoic asymmetric extension in the Northern Apennines, Italy. J. Struct. Geol. 28, $333-352$.

Coltorti M., Di Battistini G., Nappi G., Renzulli A. \& Zeda O. (1991) - Structural setting and magmatic evolution of Montefiascone volcanic complex, vulsini district, central Italy. J. Volcanol. Geoth. Res. 46, 99-124.

Condomines M., Tanguy J-C. \& Michaud V. (1995) - Magma dynamics at Mt. Etna: constraints from U-Th-Ra-Pb radioactive disequilibria and $\mathrm{Sr}$ isotopes in historical lavas. Earth Planet. Sci. Lett., 123, 25-41.

Conte A.M., Perinelli C., Bianchini G., Natali C., Martorelli E. \& Chiocci F.L. (2016) - New insights on the Petrology of submarine volcanics from the Western Pontine Archipelago (Tyrrhenian Sea, Italy). J. Volcanol. Geoth. Res. 327, $223-239$.

Conticelli S., Francalanci L., Manetti P., Peccerillo A. \& Santo A.P. (1986) - Caratteristiche composizionali dei prodotti dell'apparato di Latera (Monti Vulsini, Lazio Settentrionale) e loro significato vulcanologico. Mem. Soc. Geol. Ital. 35, 715-726.

Conticelli S., Francalanci L., Manetti P. \& Peccerillo A. (1987) - Evolution of Latera Volcano: evidence from major and trace element chemistry of pyroclastic rocks. Periodico Mineralogia 56, 175-199.

Conticelli S. \& Peccerillo A. (1990) - Petrological significance of high-pressure ultramafic xenoliths from ultrapotassic rocks of Central Italy. Lithos 24, 305-322.

Conticelli S., Francalanci L. \& Santo A.P. (1991) - Petrology of the final stage Latera lavas: Mineralogical, Geochemical and Srisotopic data and their bearing on the genesis of some potassic magmas in Central Italy. J. Volcanol. Geoth. Res. 46, $187-212$.

Conticelli S., Manetti P. \& Menichetti S. (1992) - Petrology, Chemistry, Mineralogy and Sr-isotopic features of Pliocenic Orendites from South Tuscany: implications on their genesis and evolutions. Europ. J. Mineral. 4, 1359-1375.

Conticelli S. \& Peccerillo A. (1992) - Petrology and geochemistry of potassic and ultrapotassic alkalic volcanism in Central Italy: petrogenesis and interferences on the mantle source. Lithos 28, 21-240.

Conticelli S., Francalanci L., Manetti P., Cioni R. \& Sbrana A. (1997) - Petrology and Geochemistry of the ultrapotassic rocks from the Sabatini Volcanic District, Central Italy: the role of evolutionary processes in the genesis of variably enriched alkaline magmas. J. Volcanol. Geoth. Res. 75, 107-136.

Conticelli S. (1998) - Effects of Crustal Contamination on Ultrapotassic Magmas with Lamproitic Affinity: Mineralogical, Geochemical and Isotope data from the Torre Alfina Lavas and Xenoliths, Central Italy. Chem. Geol. 149, 51-81.

Conticelli S., Bortolotti V., Principi G., Laurenzi M.A., Vagelli G. \& D'Antonio M. (2001) - Petrology, mineralogy and geochemistry of a mafic dyke from Monte Castello, Elba Island, Italy. Ofioliti 26, 249-262.

Conticelli S., D'Antonio M., Pinarelli L. \& Civetta L. (2002) - Source contamination and mantle heterogenity in the genesis of Italian potassic and ultrapotassic volcanic Rocks: Sr-Nd-Pb Isotope data from Roman Province and Southern Tuscany. Mineral. Petrol. 74, $189-222$.

Conticelli S., Melluso L., Perini G., Avanzinelli R. \& Boari E. (2004) - Petrologic, geochemical, and isotopic characteristics of potassic and ultrapotassic magmatism in Central-Southern Italy: inferences on its genesis and on the nature of mantle sources. Periodico Mineralogia 73, 153-164.

Conticelli S., Carlson R.W., Widom E. \& Serri G. (2007) - Chemical and isotopic composition (Os, Pb, Nd, and Sr) of Neogene to Quaternary calc-alkalic, shoshonitic, and ultrapotassic mafic rocks from the Italian peninsula: Inferences on the nature of their mantle sources. In: Beccaluva L., Bianchini G. \& Wilson M. (eds) Cenozoic Volcanism in the Mediterranean Area. Geol. Soc. Am., Special Paper, 418, 171-202. 
Conticelli S., Guarnieri L., Farinelli A., Mattei M., Avanzinelli R., Bianchini G., Boari E., Tommasini S., Tiepolo M., Prelévic D. \& Venturelli G. (2009a) - Trace elements and Sr-Nd-Pb isotopes of K-rich to shoshonitic and calc-alkalic magmatism of the Western Mediterranean region: genesis of ultrapotassic to calc-alkalic magmatic associations in post-collisional geodynamic setting. Lithos $107,68-92$.

Conticelli S., Marchionni S., Rosa D., Giordano G., Boari E. \& Avanzinelli R. (2009b) - Shoshonite and sub-alkaline magmas from an Ultrapotassic Volcano: Sr-Nd-Pb isotope data on the Roccamonfina volcanic rocks, Roman Magmatic Province, Southern Italy. Contrib. Mineral. Petrol. 157, 41-63.

Conticelli S., Laurenzi M.A, Giordano G., Mattei M., Avanzinelli R., Melluso L., Tommasini S., Boari E., Cifelli F. \& Perini G. (2010a) - Leucite-bearing (kamafugitic/leucititic) and -free (lamproitic) ultrapotassic rocks and associated shoshonites from Italy: constraints on petrogenesis and geodynamics. In: "The Geology of Italy". Beltrando M., Peccerillo A., Mattei M., Conticelli S. \& Doglioni C. (eds). J. Virtual Explorer 36, paper \# 20.

Conticelli S., Boari E., Avanzinelli R., De Benedetti A.A., Giordano G., Mattei M., Melluso L. \& Morra V. (2010b) - Geochemistry, isotopes and mineral chemistry of the Colli Albani volcanic rocks: constraints on magma genesis and evolution. In: "The Colli Albani Volcano", Funiciello R. \& Giordano G. (eds). The Geol. Soc. of London, 107-139.

Conticelli S., Avanzinelli R., Marchionni S., Tommasini S. \& Melluso L. (2011) - Sr-Nd-Pb isotopes from the Radicofani Volcano, Central Italy: constraints on heterogeneities in a veined mantle responsible for the shift from ultrapotassic shoshonite to basaltic andesite magmas in a post-collisional setting. Mineral. Petrol. 103, 123-148

Conticelli S., Avanzinelli R., Poli G., Braschi E. \& Giordano G. (2013) - Shift from lamproite-like to leucititic rocks: Sr-Nd-Pb isotope data from the Monte Cimino volcanic complex vs. the Vico stratovolcano, Central Italy. Chem Geol. $353,246-266$.

Conticelli S., Avanzinelli R., Ammannati E., Casalini M. (2015a) - The role of carbon from recycled sediments in the origin of ultrapotassic igneous rocks in the Central Mediterranean. Lithos 232, 174-196.

Conticelli S., Boari E., Burlamacchi L., Cifelli F., Moscardi F., Laurenzi M.A., Ferrari Pedraglio L., Francalanci L., Benvenuti M.G., Braschi E. \& Manetti P. (2015b) - Geochemistry and Sr-Nd-Pb isotopes of Monte Amiata Volcano, Central Italy: evidence for magma mixing between high-K calc-alkaline and leucititic mantle-derived magmas. Ital. J. Geosci. 134, $266-290$.

Cortini M. \& Scandone R. (1982) - Feeding system of Vesuvius between 1754 and 1944. J. Volcanol. Geotherm. Res. 12 , 393-400.

Costa A., Folch A., Macedonio G., Giaccio B., Isaia R. \& Smith V. (2012) - Quantifying volcanic ash dispersal and impact of the Campanian Ignimbrite super-eruption. Geophys. Res. Lett., 39, L10310.

Cundari A. \& Ferguson A.K. (1982) - Significance of the pyroxene chemi stry from Leucite-bearing and related assemblages. Tsch. Mineral. Petrol. Mitt. 30, 189-204.

D'Agostino N. \& McKenzie D. (1999) - Convective support of long-wavelength topography in the Apennines. Terra Nova 5, 228-233

D'Agostino N., Giuliani R., Mattone M. \& Bonci L. (2001) - Active crustal extension in the Central Apennines (Italy) inferred from GPS measurements in the interval 1994-1999. Geophys. Res. Lett. 28, 2121-2124.

D'Agostino N., Selvaggi G. (2004) - Crustal motion along the Eurasia-Nubia plate boundary in the Calabrian Arc and Sicily and active extension in the Messina Straits from GPS measurements. J. Geophys. Res. 109, B11402, doi:10.1029/2004JB002998.

D'Agostino N., Avallone A., Cheloni D., D'Anastasio E., Mantenuto S. \& Selvaggi G. (2008) - Active tectonics of the Adriatic region from GPS, earthquake slip vectors. J. Geophys. Res. 113, B12413 doi:10.1029/2008JB005860 
Dallai L., Freda C. \& Gaeta M. (2004) - Oxygen isotope geochemistry of pyroclastic clinopyroxene monitors carbonate contributions to Roman-type ultrpotassic magmas. Contrib. Mineral. Petrol. 148: 247-263

D'Antonio M., Civetta L. \& Di Girolamo P. (1999a) - Mantle source heterogeneity in the Campanian Region (South Italy) as inferred from geochemical and isotopic features of mafic volcanic rocks with shoshonitic affinity. Mineral. Petrol. 67, $163-192$.

D’Antonio M., Civetta L., Orsi G., Pappalardo L., Piochi M., Carandente A., De Vita S., Di Vito M.A. \& Isaia R. (1999b). The present state of the magmatic system of the Campi Flegrei caldera based on a reconstruction of its behaviour in the past 12 ka. J. Volcanol. Geoth. Res. 91, 247-268.

De Astis G., Pappalardo L. \& Piochi M. (2004) - Procida volcanic history: new insights into the evolution of the Phlegraean Volcanic District (Campania region, Italy). Bull. Volcanol. 66, 622-641.

De Astis G., Kempton P.D., Peccerillo A. \& Wu T.W. (2006) - Trace element and isotopic variations from Mt. Vulture to Campanian volcanoes: constraints for slab detachment and mantle inflow beneath southern Italy. Contrib. Mineral. Petrol. $151,331-351$.

De Benedetti A.A., Funiciello R., Giordano G., Diano G., Caprilli E. \& Paterne M. (2008) - Volcanology, History and Myths of the Lake Albano maar (Colli Albani volcano, Italy)". J.Volcanol. Geoth. Res. 176, 387-406.

De Fino M., La Volpe L., Peccerillo A., Piccarreta G. \& Poli G. (1986) - Petrogenesis of Monte Vulture volcano (Italy): inferences from mineral chemistry, major and trace element data. Contrib. Mineral. Petrol. 92, 135-145.

De Gori P., Cimini G.B., Chiarabba C., De Natale G., Troise C. \& Deschamps A. (2001) - Teleseismic tomography of the Campanian volcanic area and surrounding Apenninic belt. J. Volcanol. Geotherm. Res. 109, 55- 75.

De Natale G., Troise C., Pingue F., Mastrolorenzo G. \& Pappalardo L. (2006) - The Somma-Vesuvius volcano (Southern Italy): Structure, dynamics and hazard evaluation. Earth-Science Rev. 74, 73-111.

Deino A.L., Orsi G., De Vita S. \& Piochi M. (2004) - The age of the Neapolitan Yellow Tuff caldera-forming eruption (Campi Flegrei caldera, Italy) assessed by 40Ar/39Ar dating method. J. Volcanol. Geother. Res. 133, 157-170.

Del Gaudio C., Aquino I., Ricciardi G.P., Ricco C. \& Scandone R. (2010) - Unrest episodes at Campi Flegrei: a reconstruction of vertical ground movements during 1905-2009. J. Volcanol. Geotherm. Res. 185, 48-56.

De Rita D., Faccenna C., Funiciello R. \& Rosa C. (1995) - Stratigraphy and volcano-tectonics. In: "The Volcano of the Alban Hills", Trigila R. (edt), Tipografia Sgs Roma, 33-71.

De Rita D. \& Giordano G. (1996) - Volcanological and structural evolution of Roccamonfina volcano (southern italy). In: "Volcano instability on Earth and other Planets", McGuire W.J., Jones A., Neuberg J. (edts), Geol. Soc. London, Spec. Pub. $110,209-224$.

De Rita D., Giordano G. \& Milli S. (1998) - Forestepping- Backstepping stacking pattern of volcaniclastic successions: Roccamonfina volcano (Italy). J. Volcanol. Geother. Res. 80, 155-178.

De Rita D., Giordano G., Esposito A., Fabbri M. \& Rodani S. (2002) - Large volume, middle Pleistocene, phreatomagmatic ignimbrites from the Colli Albani volcano: stratigraphy, eruptive history and structural control. J. Volcanol. Geoth. Res. 118, 77-98.

De Vita S., Orsi G., Civetta L., Carandente A., D'Antonio M., Di Cesare T., Di Vito M., Fisher R.V., Isaia R., Marotta E., Ort M., Pappalardo L., Piochi M. \& Southon J. (1999) - The Agnano-Monte Spina eruption (4.1 ka) in the resurgent, nested Campi Flegrei caldera (Italy). J. Volcanol. Geoth. Res. 91, 269-301.

De Vivo B., Rolandi G., Gans P.B., Calvert A., Bohrson W.A., Spera F.J. \& Belkin H.E. (2001) - New constraints on the pyroclastic eruptive history of the Campanian volcanic Plain (Italy). Mineral. Petrol. 73, 47-65. 
Dewey J.F., Helman M.L., Turco E., Hutton D.H.W. \& Knott S.D. (1989) - Kinematics of the Western Mediterranean. In: "Alpine Tectonics", Coward M.P., Dietrich D. \& Park R.G. (eds.), Geol. Soc. London, Spec. Pub. 45, $265-283$.

Diano G., Bonamico A. \& Giordano G. (2010) - Three-dimensional reconstruction of the main unconformities of the Colli Albani stratigraphy and deposit volume calculations. In: "The Colli Albani Volcano", Funiciello R. \& Giordano G. (eds), The Geol. Soc. of London, 177-188.

Di Battistini G., Montanini A., Vernia L., Bargossi G.M. \& Castorina F. (1998) - Petrology and geochemistry of ultrapotassic rocks from the Montefiascone Volcanic Complex (Central Italy): magmatic evolution and petrogenesis. Lithos 43. $169-195$.

Di Battistini G., Montanini A., Vernia L., Venturelli G. \& Tonarini S. (2001) - Petrology of melilite-bearing rocks from Montefiascone Volcanic Complex (Roman Province): new insights into the ultrapotassic volcanism of Central Italy. Lithos 59, 1-24.

Di Bona, M., Lucente, F.P. \& Piana Agostinetti N. (2008) - Crustal structure and Moho depth profile crossing the central Apennines (Italy) along the N42 degree parallel. J. Geophys. Res. 113. DOI: 10.1029/2008JB005625.

Di Filippo M. \& Toro B. (1980) - Analisi gravimetrica delle strutture del Lazio meridionale. Geologica Romana 19, 285-294

Di Girolamo P., Nardi G., Rolandi G. \& Stanzione D. (1976) - Occurrence of calk-alkaline two-pyroxene andesites from deep boreholes in the Phlegrean Fields. 1 - Petrographic and petrochemical data. Rend. Accademia Sci. Fisiche Matematiche XLIII, 1-29.

Di Girolamo P., Ghiara M.R., Lirer L., Munno R., Rolandi G., Stanzione D. (1984) - Vulcanologia e petrologia dei Campi Flegrei. Boll. Soc. Geol. It., 103, 349-413.

Di Girolamo P., Melluso L. \& Morra V. (1991) - Magmatic activity of Roccamonfina volcano (Southern Italy): Petrology, geochemistry and relationships with campanian volcanics. Neus Jb. Mineral Petrol. Abh. 163, 271-289.

Di Maio R., Mauriello P., Patella D., Petrillo Z., Piscitelli S. \& Siniscalchi A. (1998) - Electric and electromagnetic outline of the Mount Somma-Vesuvius structural setting. J. Volcanol. Geotherm. Res. 82, 219-238.

Di Renzo V., Di Vito M.A., Arienzo I., Carandente A., Civetta L., D'Antonio M., Giordano F., Orsi G. \& Tonarini S. (2007) - Magmatic history of Somma-Vesuvius on the basis of new geochemical and isotopic data from a deep borehole (Camaldoli della Torre). J. Petrology 48, 4, 753-784.

Di Renzo V., Arienzo I., Civetta L., D’Antonio M., Tonarini S., Di Vito M.A. \& Orsi G. (2011) - The magmatic feeding system of the Campi Flegrei caldera: architecture and temporal evolution. Chem. Geol. 281, 227-241.

Di Rocco T., Freda C., Gaeta M., Mollo S. \& Dallai L. (2012) - Magma Chambers Emplaced in Carbonate Substrate: Petrogenesis of Skarn and Cumulate Rocks and Implications for CO2 Degassing in Volcanic Areas. J. Petrology, 53, $2307-2332$.

Di Vito M.A., Isaia R., Orsi G., Southon J., de Vita S., D'Antonio M., Pappalardo L. \& Piochi M. (1999) - Volcanism and deformation since 12000 years at the Campi Flegrei caldera (Italy). J. Volcanol. Geoth. Res., 91, 221-246.

Doglioni C. (1991) - A proposal for the kinematic modelling of W-dipping subductions - possible applications to the TyrrhenianApennines system. Terra Nova, 3, 423-434.

Doglioni C., Harabaglia P., Merlini S., Mongelli F. \& Peccerillo A. (1999) - Orogens and slabs vs. their direction of subductions. Earth Sci. Rev., 45, 167-208.

D'Orazio M., Laurenzi M.A. \& Villa I.M. (1991) - 40Ar/39Ar dating of a shoshonitic lava flow of the Radicofani volcanic center (Southern Tuscany). Acta Vulcanologica, 1, 63-67. 
D'Orazio M., Innocenti F., Tonarini S., Doglioni C. (2007) - Carbonatites in a subduction system: the Pleistocene Alvikites from Mt. Vulture (Southern Italy). Lithos 98, 313-334.

D'Orazio M., Innocenti F., Tonarini S. \& Doglioni C. (2008) - Reply to the discussion of "Carbonatites in a subduction system: the Pleistocene Alvikites from Mt. Vulture (Southern Italy)" by D'Orazio, M., Innocenti, F., Tonarini, S., Doglioni, C. (Lithos 98, 313334) by F. Stoppa, C. Principe, and P. Giannandrea. Lithos 103, 557-561.

D'Oriano C., Poggianti E., Bertagnini A., Cioni R., Landi P., Polacci M. \& Rosi M. (2005) - Changes in eruptive style during the A.D. 1538 Monte Nuovo eruption (Phlegrean Fields, Italy): the role of syn-eruptive crystallization. Bull. Volcanol. 67, 601-621.

Downes H., Kostoula T., Jones A.P., Beard A.D., Thirlwall M.F. \& Bodinier J.-L. (2002) - Geochemistry and Sr-Nd isotopic compositions of mantle xenoliths from the Monte Vulture carbonatite-melilitite volcano, central southern Italy. Contrib. Mineral. Petrol. 144 78-92.

Dvorak J.J. \& Gasparini P. (1991) - History of earthquakes and vertical ground movement in Campi Flegrei caldera, Southern Italy: comparison of precursory events to the A.D. 1538 eruption of Monte Nuovo and of activity since 1968 . J. Volcanol. Geotherm. Res., 48, 77-92.

Elliott T., Plank T., Zindler A., White W. \& Bourdon B. (1997) - Element transport from slab to volcanic front at the Mariana arc. J. Geophys. Res. 102, 14991-15019.

Elliott T. (2003) - Tracers of the slab. In: Inside the Subduction Factory, Eiler J. (ed.). Geophys. Monograph 138, Am. Geophys. Union, 23-45.

Evernden J.F. \& Curtis G.H. (1965) - The potassium-argon dating of late Cenozoic rocks in East Africa and Italy. Current Antropology 6, 343-385.

Faccenna C., Funiciello R., Bruni A., Mattei M. \& Sagnotti L. (1994) - Evolution of a transfer-related basin: the Ardea Basin (Latium, central Italy). Basin Res. 6, 35-46

Faccenna C., Mattei M., Funiciello R. \& Jolivet L. (1997) - Styles of back-arc extension in the Central Mediterranean. Terra Nova 9, 126-130.

Faccenna C., Funiciello F., Giardini D. \& Lucente P. (2001) - Episodic back-arc extension during restricted mantle convection in the Central Mediterranean. Earth Planet. Sci. Lett. 187, 105-116.

Faccenna C., Piromallo C., Crespo-Blanc A., Jolivet L. \& Rossetti F. (2004) - Lateral slab deformation and the origin of the western Mediterranean arcs. Tectonics 23, TC1012 doi: 10.1029/2002TC001488.

Fedele F.G., Giaccio B., Isaia R. \& Orsi G. (2003) - The Campanian Ignimbrite eruption, Heinrich event 4 and the Palaeolithic change in Europe: a high-resolution investigation. In A. Robock \& C. Oppenheimer (eds.) "Volcanism and Earth's Atmosphere". Washington, USA, AGU Geophysical Monograph 139, 301-325.

Fedele L., Morra V., Perrotta A.M. \& Scarpati C. (2006) - Volcanological and geochemical features of the products of the Fiumicello eruption, Procida island, Campi Flegrei (southern Italy). Periodico Mineralogia 75, 43-72.

Fedele L., Scarpati C., Lanphere M., Melluso L., Morra V., Perrotta A. \& Ricci G. (2008) - Breccia Museo formation, Campi Flegrei, southern Italy: geochronology, chemostratigraphy and relationship with the Campanian Ignimbrite eruption. Bull. Volcanol. 70, 1189-1219. 
Fedele L., Scarpati C., Sparice D., Perrotta A., Laiena F. (2016) - A chemostratigraphic study of the Campanian Ignimbrite eruption (Campi Flegrei, Italy): Insights on magma chamber withdrawal and deposit accumulation as revealed by compositionally zoned stratigraphic and facies framework. J. Volcanol. Geoth. Res. 324, 105-117.

Federico M., Peccerillo A., Barbieri M. \& Wu T.W. (1994) - Mineralogical and geochemical study of granular xenoliths from Alban Hills volcano, Central Italy: evolutionary processes in potassic magma chambers. Contrib. Mineral. Petrol. 115, 384-401.

Federico M. \& Peccerillo A. (2002) - Mineral chemistry and petrogenesis of granular ejecta from the Alban Hills volcano (Central Italy). Mineral. Petrol., 74, 223-252.

Ferrara G., Laurenzi M.A., Taylor H.P. Jr, Tonarini S. \& Turi B. (1985) - Oxygen and Sr- Isotope studies of K-Rich volcanic rocks from the Alban Hills, Italy. Earth Planet. Sci. Lett. 75, 13-28.

Fisher R.V., Orsi G., Ort M. \& Heiken G. (1993) - Mobility of a large-volume pyroclastic flow-emplacement of the Campanian ignimbrite, Italy. J. Volcanol. Geoth. Res. 56, 205-220.

Florindo F., Karner D.B., Marra F., Renne P.R., Roberts A.P., Weaver R. (2007) - Radioisotopic age constraints for Glacial Terminations IX and VII from aggradational sections of the Tiber River delta in Rome, Italy. Earth Planet. Sci. Lett. 256, 61-80.

Foley, S.F., 1992a. Petrological characterisation of the source components of potassic magmas: geochemical and experimental constraints. Lithos 28, 187-204.

Foley S.F. (1992b) - Vein-plus-wall-rock melting mechanisms in the lithosphere and the origin of potassic alkaline magmas. Lithos $28,435-453$.

Foley S.F., Venturelli G., Green D.H., Toscani L. (1987) - The ultrapotassic rocks: characteristics, classification and constraints for petrogenetic models. Earth Sci. Rev. 24, 81-134.

Foley S.F. \& Venturelli G. (1989) - High-K ${ }_{2} \mathrm{O}$ rocks with high MgO, high $\mathrm{SiO}_{2}$, affinities. In: "Boninites". Crawford A.J. (ed.) Unwin Hyman, 72-88.

Fornaseri M. \& Scherillo A. (1963) - Petrografia dei Colli Albani. In: "La Regione Vulcanica dei Colli Albani", Fornaseri M., Scherillo A. \& Ventriglia U. (eds.), Consiglio Nazionale delle Ricerche, 340-550.

Fornaseri M. (1985a) - Geochronology of Volcanic rocks from Latium (Italy). Rendiconti Soc. Ital. Mineral. Petrol. 40 , $73-105$.

Fornaseri M. (1985b) - Geochronology of Volcanic rocks from Umbria (Italy). Rendiconti Soc. Ital. Mineral. Petrol. 40, $107-110$.

Francalanci L., Peccerillo A. \& Poli G. (1987) - Partition coefficients for minerals in potassium-alkaline rocks: Data from Roman province (Central Italy). Geochem. J. 21, 1-10.

Freda C., Palladino D.M., Pignatti S., Trigila R., Onorati G. \& Poscolieri M. (1990) - Volcano-tectonic scenario of Vulsini volcanoes (Central Italy) from LANDSAT-MSS images and digital elevation data. ISPRS J. Photogrammetry Remote Sensing, $45,316-328$.

Freda C., Gaeta M., Palladino D.M. \& Trigila R. (1997) - The Villa Senni Eruption (Alban Hills, Central Italy): the role of H ${ }_{2}$ O and $\mathrm{CO}_{2}$ on magma chamber evolution and on eruptive scenario. J. Volcanol. Geotherm. Res. 78, $103-120$.

Freda C., Gaeta M., Karner D.B., Marra F., Renne P.R., Taddeucci J., Scarlato P., Christensen J.N. \& Dallai L. (2006) - Eruptive history and petrologic evolution of the Albano multiple maar (Alban Hills, Central Italy). Bull. Volcanol. 68, 567-591.

Freda C., Gaeta M., Giaccio B., Marra F., Palladino D.M., Scarlato P. \& Sottili G. (2011) - $\mathrm{CO}_{2}$-driven large mafic explosive eruptions: the Pozzolane Rosse case study from the Colli Albani Volcanic District (Italy). Bull. Volcanol. 73, $241-256$. 
Frezzotti M.L., De Astis G., Dallai L. \& Ghezzo C. (2007) - Corexisting calc-alkaline and ultrapotassic magmatism at Monti Ernici, Mid Latina Valley (Latium, central Italy). Europ. J. Mineral. 19, 479-497.

Frezzotti M.L., Peccerillo A. \& Panza G. (2009) - Carbonate metasomatism and CO2 lithosphere-asthenosphere degassing beneath the Western Mediterranean: An integrated model arising from petrological and geophysical data. Chem Geol. $262,108-120$.

Frost B.R. \& Frost C.D. (2008) - A geochemical classification for feldspathic igneous rocks. J. Petrol. 49, 1955-1969.

Fulignati P., Marianelli P., Santacroce R. \& Sbrana A. (2004) - Probing the Vesuvius magma chamber-host rock interface through xenoliths. Geol. Mag. 141, 417-428.

Fulignati P., Panichi C., Sbrana A., Caliro S., Gioncada A. \& Del Moro A. (2005) - Skarn formation at the walls of the 79AD magma chamber of Vesuvius (Italy): Mineralogical and isotopic constraints. N. Jahrb. Mineralogie-Abhandlungen 181, 53-66.

Funiciello R. \& Parotto M. (1978) - Il substrato sedimentario nell'area dei Colli Albani: considerazioni geodinamiche e paleogeografiche sul margine tirrenico dell'appennino Centrale. Geol. Romana 17, 233-287.

Funiciello R., Giordano G. \& De Rita D. (2003) - The Albano maar Lake (Colli Albani Volcano, Italy): recent activity and evidence of pre-roman age catastrophic lahar events. J. Volcanol. Geotherm. Res. 123: 43-61

Funiciello R., De Benedetti A.A., Heiken G. \& Giordano G. (2010) - Volcanic Activity of the Lake Albano Maar in Roman History and Mythology. In: "The Colli Albani Volcano", Funiciello R. \& Giordano G. (eds). The Geol. Soc. of London, $331-338$.

Funiciello R. \& Giordano G. (eds) (2010) - Colli Albani volcano, Special Publication of IAVCEI, 3. The Geological Society, London.

Gaeta M., Fabrizio G. \& Cavarretta G. (2000) - F-phlogopite in the Alban Hills Volcanic District (Central Italy): indications regarding the role of volatiles in magmatic crystallisation. J. Volcanol. Geoth. Res. 99, 179-193.

Gaeta M., Freda C., Christensen J.N., Dallai L., Marra F., Karner D.B., Scarlato P. (2006) - Time-dependent geochemistry of clinopyroxene from the Alban Hills (Central Italy): clues to source and evolution of ultrapotassic magmas. Lithos, 86, 330-346.

Gaeta M., Di Rocco T., Freda C. (2009) - Carbonate Assimilation in Open Magmatic Systems: the Role of Melt-bearing Skarns and Cumulate-forming Processes. J. Petrology 50, 361-385.

Gaeta M., Freda C., Marra F., Di Rocco T., Gozzia F., Arienzo I., Giaccio B. \& Scarlato P. (2011) - Petrology of the most recent ultrapotassic magmas from the Roman Province (Central Italy). Lithos 127, 298-308.

Gallo F., Giammetti F., Venturelli G., Vernia L. (1984) - The kamafugitic rocks of San Venanzo and Cupaello, Central Italy. N. Jahrb. Mineral. Monat. 1984, 198-210.

Gasparon M., Rosembaum G., Wijbrans J. \& Manetti P. (2008) - The transition from subduction arc to slab tearing: Evidence from Capraia Island, northern Tyrrhenian Sea. J. Geodyn. 47, 1, 30-38.

Gasperini D., Blichert-Toft J., Bosch D., Del Moro A., Macera P. \& Albarède F. (2002) - Upwelling of deep mantle material through a plate window: Evidence from the geochemistry of Italian basaltic volcanics. J. Geophys. 107, DOI: 10.1029/2001JB000418

Giaccio B., Sposato A., Gaeta M., Marra F., Palladino D.M., Taddeucci J., Barbieri M., Messina P. \& Rolfo M.F. (2007) - Mid-distal occurrences of the Albano Maar pyroclastic deposits and their relevance for reassessing the eruptive scenarios of the most recent activity at the Colli Albani Volcanic District, Central Italy. Quat. Intern. 171-172, 160-178.

Giaccio B., Isaia R., Fedele F., Di Canzio E., Hoffecker J., Ronchitelli A., Sinitsyn A., Anikovich M., Lisitsyn S. \& Popov V. (2008) The Campanian Ignimbriteand Codola tephra layers: two temporal/stratigraphic markers for the Early UpperPalaeolithic in southern Italy and eastern Europe. J. Volcanol. Geoth. Res. 177, 208-226. 
Giaccio B., Marra F., Hajdas I., Karner D.B., Renne P.R. \& Sposato A. (2009) - 40Ar/39Ar and 14C geochronology of the Albano maar deposits: Implications for defining the age and eruptive style of the most recent explosive activity at Colli Albani Volcanic District, Central Italy. J. Volcanol. Geotherm. Res. 185, 203-213.

Giannetti B. (1964) - Carta Geopetrografica della caldera vulcanica di Roccamonfina. Grafica Editoriale Cartografica, Roma.

Giannetti B. \& Luhr J.F. (1983) - The White Trachitic Tuff of Roccamonfina volcano (Roman Region, Italy). Contrib. Mineral. Petrol. $84,235-252$.

Giannetti B. \& Masi U. (1992) - Trace element behaviour during weathering of leucite in potassic rocks from the Roccamonfina volcano (Campania, Southern Italy) and environmental implications. Lithos 22, 317-324.

Giannetti B. \& Ellam R. (1994) - The primitive lavas of Roccamonfina volcano, Roman region, Italy: new constraints on melting processes and source mineralogy. Contrib. Mineral. Petrol. 116, 21-31.

Giannetti B. \& De Casa G. (2000) - Stratigraphy, chronology and sedimentology of the White Trachytic Tuff, Roccamonfina volcano, Italy. J. Volcanol. Geotherm. Res. 96, 243-295.

Giannetti B. (2001) - Origin of the calderas and evolution of Roccamonfina volcano (Roman Region, Italy). J. Volcanol. Geoth. Res. 106, 301-319.

Gillot P.Y., Chiesa S., Pasquaré G. \& Vezzoli L. (1982) - <33,000-yr K-Ar dating of the volcano-tectonic horst of the Isle of Ischia, Gulf of Naples. Nature 299, 242-244.

Giordano G. \& Dobran F. (1994) - Computer simulations of the Tuscolano Artemisio's IInd pyroclastic flow unit (Alban Hills, Central Italy). J. Volcanol. Geotherm. Res., 61: 69-94

Giordano G., Scrocca D., Naso G., Funiciello R. \& Catalani F. (1995) - Processi di estensione e circolazione di fluidi a bassa termalità nella piana di Riardo (Caserta). Boll. Soc. Geol. Ital. 114, 361-371.

Giordano G. (1998a) - Facies characteristics and magma-water interaction of the White Trachytic Tuffs (Roccamonfina Volcano, Italy). Bull. Volcanol. 60, 10-26.

Giordano G. (1998b) - The effect of paleotopography on lithic distribution and facies associations of small volume ignimbrites: an insight into transport and depositional systems of WTT Cupa deposits (Roccamonfina volcano, Italy). J. Volcanol. Geother. Res. 87, 255-273.

Giordano G., De Benedetti A.A., Diana A., Diano G., Gaudioso F., Marasco F., Miceli M., Mollo S., Cas R.A.F. \& Funiciello R. (2006a) - The Colli Albani caldera (Roma, Italy): stratigraphy, structure and petrology. J. Volcanol. Geoth. Res. 155, 49-80.

Giordano G., De Rita D., Fabbri M. \& Rodani S. (2006b) - Geological Map of volcanic regions: Roccamonfina. In: "Mapping Geology in Italy" Pasquarè G. \& Venturini C. (eds), APAT, S.e.l.c.a., Firenze, 131-136.

Giordano G. \& CARG team (2010) - Stratigraphy and volcano-tectonic structures of the Colli Albani volcanic field. In: "The Colli Albani Volcano", Funiciello R. \& Giordano G. (eds). The Geol. Soc. of London, 15-45.

Giordano G., Mattei M. \& Funiciello R. (2010) - Geological map of the Colli Albani volcano. In: "The Colli Albani Volcano", Funiciello R. \& Giordano G. (eds), The Geol. Soc. of London, insert.

Giordano G., De Rita D., Cas R.A.F. \& Rodani S. (2002) - Valley pond and ignimbrite veneer deposits in the small-volume phreatomagmatic 'Peperino Albano' basic ignimbrite, Lago Albano maar, Colli Albani volcano, Italy: influence of topography. J. Volcanol. Geoth. Res., 118, 131-144. 
Goes S., Giardini D., Jenny S., Hollenstein C., Kahleb H.G. \& Geigerb A. (2004) - A recent tectonic reorganization in the southcentral Mediterranean. Earth Planet. Sci. Lett. 226, 335-345.

Gragnani R. (1972) - Le vulcaniti melilitiche di Cupaello (Rieti). Rendiconti Società Italiana di Mineralogia e Petrologia $28,165-189$.

Giudicepietro F. \& D'Auria L. (2013) - Storia del dibattito scientifico sul Serapeo di Pozzuoli. Miscellanea INGV $20,1-15$.

Guidoboni E. \& Ciuccarelli C. (2011) - The Campi Flegrei caldera: historical revision and new data on seismic crises, bradyseisms, the Monte Nuovo eruption and ensuing earthquakes (twelfth century 1582 ad). Bull. Volcanol., 73, 655-677.

Gurioli L., Cioni R., Sbrana A. \& Zanella E. (2002) - Transport and deposition of pyroclastic flows over an inhabited area: the deposits of the AD 79 eruption of Vesuvius at Herculaneum (Italy). Sedimentology 49, 929-953.

Gurioli L., Houghton B.F., Cashman K.V. \& Cioni R. (2004) - Complex changes in eruption dynamics during the 79 AD eruption of Vesuvius. Bull. Volcanol. 67, 144-159.

Hawkesworth C.J. \& Vollmer R. (1979) - Crustal contamination versus enriched mantle: $143 \mathrm{Nd} / 144 \mathrm{Nd}$ and $87 \mathrm{Sr} / 86 \mathrm{Sr}$ evidence from the Italian volcanics. Contrib. Mineral. Petrol. 69, 151-165.

Hawkesworth C.J., Turner S.P., Peate D.W., McDermott F., van Calsteren P. (1997) - U-Th isotopes in arc magmas: implications for element transfer from the subducted crust. Science 276, 551-555.

Hermann J. (2002) - Allanite: thorium and light rare earth element carrier in subducted crust. Chem. Geol. 192, $289-306$.

Hermann J., Spandler C., Hack A., Korsakov A.V. (2006) - Aqueous fluids and hydrous melts in high-pressure and ultra-high pressure rocks: Implications for element transfer in subduction zones. Lithos 92, 399-417.

Hoefs J. (2010) - Geochemical fingerprints: a critical appraisal. Europ. J. Mineral. 22, 3-16.

Hofmann A.W. (1997) - Mantle geochemistry: the message from oceanic volcanism. Nature 385, $219-229$.

Holm P.M. (1982) - Mineral chemistry in perpotassic lavas of Vulsinian District, Roman Province, Italy. Mineral. Mag. 46, $379-386$.

Holm P.M., Lou S., Nielsen $\AA$. (1982) - The geochemistry and petrogenesis of the lavas of the Vulsinian District, Roman province, Central Italy. Contrib. Mineral. Petrol. 80, 367-378.

Holmes A. \& Harwood H.F. (1932) - Petrology of the volcanic fields East and South-East of Ruwenzori, Uganda. Quarter. J. Geol. Soc. of London $88,370-442$.

Horvath F. \& Berckheimer H. (1982) - Mediterranean backarc-basins. In: H. Berckheimer and K. Hsü (Edts), AlpineMediterranean-Geodynamics. AGU Geodynamics Series, 141-163.

Hunstad I., Selvaggi G., D'Agostino N., England P., Clarke P. \& Pierozzi M. (2003) - Geodetic strain in peninsular Italy between 1875 and 2001. Geophys. Res. Lett. 30, 1181. doi:10.1029/2002GL016447.

Hunziker J.C. (1974) - Rb-Sr age determination and the Alpine tectonic history of the Western Alps. Mem. Istituto Geol. Mineral. Università di Padova 31, 1-54.

Iacono-Marziano G., Gaillard F. \& Pichavant M. (2007) - Limestone Assimilation and the origin of CO2 emissions at the Alban Hills (Central Italy): constraints from experimental petrology. J. Volcanol. Geotherm. Res. 155, 719-738.

Iacono-Marziano G., Gaillard F. \& Pichavant M. (2008) - Limestone assimilation by basaltic magmas: an experimental reassessment and application to Italian volcanoes. Contributions to Mineralogy and Petrology, 155, $719-738$.

Isaia R., D'Antonio M., Dell'Erba F., Di Vito M. \& Orsi G. (2004) - The Astroni volcano: the only example of closely spaced eruptions in the same vent area during the recent history of the Campi Flegrei caldera (Italy). J. Volcanol. Geother. Res. $133,171-192$. 
Isaia R., Marianelli P. \& Sbrana A. (2009) - Caldera unrest prior to intense volcanism in Campi Flegrei (Italy) at 4.0 ka B.P.: implications for caldera dynamics and future eruptive scenarios. Geoph. Res. Lett., 36, L21303. doi:10.1029/2009GL040513.

Isaia R. \& Smith V.C. (2013) - Tefrostratigrafia del vulcanismo ai Campi Flegrei negli ultimi 15 ka. In M. Di Vito \& S. de Vita (eds.)

"L'impatto delle Eruzioni Vulcaniche sul Paesaggio, sull'Ambiente e sugli Insediamenti Umani - Approcci Multidisciplinari di tipo Geologico, Archeologico E Biologico". Miscellanea INGV, Scuola Estiva AIQUA 2013, Napoli, 22-26.

Isaia R., Vitale S., Di Giuseppe M.G., Iannuzzi E., Tramparulo F. \& Troiano A. (2015) - Stratigraphy, structure and volcano-tectonic evolution of Solfatara maar-diatreme (Campi Flegrei, Italy). GSA Bull., 127, 1485-1504.

Iuliano T., Mauriello P. \& Patella D. (2002) - Looking inside Mount Vesuvius by potential fields integrated probability tomographies. J. Volcanol. Geotherm. Res., 113, 363-378.

Jolivet L., Faccenna C., Goffé B., Mattei M., Rossetti F., Brunet C., Storti F., Funiciello R., Cadet J.P., D'Agostino N. \& Parra T. (1998) Midcrustal shear zones in postorogenic extension: Example from the northern Tyrrhenian Sea. J. Geophys. Res. 103, $12123-12160$.

Jones A.P., Kostoula T., Stoppa F. \& Wolley A.R. (2000) - Petrography and mineral chemistry of mantle xenoliths in a carbonaterich melilitic tuff from Mt. Vulture volcano, southern Italy. Mineral. Mag., 64, 341-361.

Joron J.L., Métrich N., Rosi M., Santacroce R. \& Sbrana A. (1987) - Chemistry and petrography. In: "Somma-Vesuvius" R. Santacroce ed., CNR Quaderni Ricerca Sci., 8, 105-174.

Karner D.B. \& Renne P.R (1998) - 40Ar/39Ar geochronology of Roman volcanic province tephra in the Tiber River valley: Age calibration of middle Pleistocene sea-level changes. Geol. Soc. Am. Bull., 110, 740-747.

Karner D.B., Marra F., Florindo F. \& Boschi E. (2001a) - Pulsed uplift estimated from terrace elevations in the coast of Rome: evidence for a new phase of volcanic activity? Earth Planet. Sci. Lett., 188, 135-148.

Karner D.B., Marra F. \& Renne P.R. (2001b) - The history of the Monti Sabatini and Alban Hills volcanoes: groundwork for assessing volcano-tectonic hazard for Rome. J. Volcanol. Geoth. Res. 107, 185-219.

Karner D.B., Renne P.R., McDougall I. \& Becker T. (2001c) - The viability of leucite for 40Ar/39Ar dating and as a Quaternary standard. Chem. Geol., 177, 473-482.

Kastens K., Mascle J., Auroux C., Bonatti E., Broglia C., Channell J., Curzi P., Emeis K.-C., Glaçon G., Hasegawa S., Hieke W., Mascle G., McCoy F., McKenzie J., Mendelson J., Müller C., Réhault J.P., Robertson A., Sartori R., Sprovieri R. \& Torii M. (1988) - ODP Leg 107 in the Tyrrhenian Sea: Insights into passive margin and back-arc basin evolution. Geol. Soc. Am. Bull., 100, $1140-1156$.

Kerrick D.M. \& Connolly J.A.D. (2001) - Metamorphic devolatilization of subducted marine sediments and the transport of volatiles into the Earth's mantle. Nature, 411, 293-296

Kessel R., Schmidt M.W., Ulmer P. \& Pettke T. (2005) - Trace element signature of subduction-zone fluids, melts and supercritical liquids at 120-180 km depth. Nature, 437, 724-727.

Klimm K., Blundy J.D. \& Green T.H. (2008) - Trace element partitioning and accessory phase saturation during H2O-saturated melting of basalt with implications for Subduction zone chemical fluxes. J. Petrol., 49, 523-553.

LaBerge R.D., Giordano G., Cas R.A.F. \& Ailleres L. (2006) - Syn-depositional substrate deformation produced by the shear force of a pyroclastic density current: an example from the Pleistocene ignimbrite at Monte Cimino, northern Lazio, Italia. J. Volcanol. Geoth. Res., 158, 307-320. 
LaBerge R.D., Porreca M., Mattei M., Giordano G. \& Cas R.A.F. (2008) - Meandering flow of a pyroclastic density current documented by the anisotropy of magnetic susceptibility (AMS) in the quartz latite ignimbrite of the Pleistocene Monte Cimino volcanic centre (central Italy). Tectonophysics 466, 64-78.

Landi P., Bertagnini A. \& Rosi M. (1999) - Chemical zoning and crystallization mechanisms in the magma chamber of the Pomici di Base plinian eruption of Somma-Vesuvius (Italy), Contrib. Mineral. Petrol. 135, 179-197.

Lardini D. \& Nappi G. (1987) - I cicli eruttivi del complesso vulcanico Cimino. Rendiconti Soc. Ital. Mineral. Petrol., $42,141-153$. Laurenzi M.A. (1980) - Geochimica isotopica e geologia dell'area vulcanica dei Colli Albani (in Italian). Thesis, Univ. of Rome, 56 pp. Laurenzi M.A. \& Villa I.M. (1987) - 40Ar/39Ar chronostratigraphy of Vico ignimbrites. Periodico Mineralogia 56, $285-293$.

Laurenzi M.A., Ballini A., Barberi F., Mezzetti F., Oddone M., Villa I.M. (1990) - High resolution chronostratigraphy of Roccamonfina volcano (Italy). ICOG VII, Geol. Soc. Australia 27, p. 57.

Laurenzi M.A., Stoppa F. \& Villa I.M. (1994) - Eventi ignei monogenetici e depositi piroclastici nel Distretto Ultra-alcalino UmbroLaziale (ULUD): revisione, aggiornamento e comparazione dei dati cronologici. Plinius 12, 61-65.

Laurenzi M.A. \& Deino A.L. (1996) - 40Ar-39Ar single-crystal dating of Vulsinian Basal Ignimbrite (Central Italy). Eos, Transactions, AGU, $77(46)$, F794.

Laurenzi M.A. (2005) - Comment on "Recurrence of volcanic activity along the Roman Comagmatic Province (Tyrrhenian margin of Italy) and its tectonic significance" by F. Marra, J. Taddeucci, C. Freda, W. Marzocchi,, P. Scarlato. Tectonics, 24, TC5006, doi: 10.1029/2004TC001780.

Laurenzi M., Braschi E., Casalini M. \& Conticelli S. (2015a) - New 40Ar-39Ar dating and revision of the Geochronology of the Monte Amiata volcano, Central Italy. Ital. J. Geosci., 134, 255-265.

Le Bas M.J. (1999) - Sövite and alvikite; two chemically distinct calciocarbonatites C1 and C2. South African J. Geol. 102, $109-121$. Le Maitre R.W. (2002) - Igneous Rocks. A Classification and Glossary of Terms. Recommendations of the International Union of Geological Sciences Subcommission on the Systematics of Igneous Rocks. Cambridge University Press, 236 pp.

Lirer L., Pescatore T., Booth B. \& Walker G.P.L. (1973) - Two Plinian pumice-fall deposits from Somma-Vesuvius, Italy. Geol. Soc. Am. Bull. 84, 759-772.

Lirer L., Luongo G. \& Scandone R. (1987) - On the volcanological evolution of Campi Flegrei. EOS 68, $226-234$.

Lombardi G., Nicoletti M. \& Petrucciani C. (1974) - Età delle vulcaniti acide dei complessi Tolfetano, Cerite e Manziate (Lazio Nord-Occidentale). Periodico Mineralogia 43, 181-204.

Lonergan L. \& White N. (1997) - Origin of the Betic-Rif mountain Belt. Tectonics 16, 504-522.

Luhr J.F. \& Giannetti B. (1987) - The Brown Leucitic Tuff of Roccamonfina volcano (Roman Region, Italy). Contrib. Mineral. Petrol. 95, $420-436$. Lustrino M., Morra V., Melluso L., Brotzu P. \& D'Amelio F. (2004) - The Cenozoic igneous activity in Sardinia. Periodico Mineralogia 73, 105-134.

Lustrino M., Duggen S. \& Rosenberg C.L. (2011) - The Central-Western Mediterranean: Anomalous igneous activity in an anomalous collisional tectonic setting. Earth-Science Rev. 104, 1-40.

Lustrino M., Fedele L., Melluso L., Morra V., Ronga F., Geldmacher J., Duggen S., Agostini S., Cucciniello C., Franciosi L. \& Meisel T. (2013) - Origin and evolution of Cenozoic magmatism of Sardinia (Italy). A combined isotopic (Sr-Nd-Pb-O-Hf-Os) and petrological view. Lithos $180-181,138-158$. 
Magri D. \& Sadori L. (1999) - Late Pleistocene and Holocene pollen stratigraphy at Lago di Vico, central Italy. Vegetation History and Archaeobotany, 8, 247-260.

Malinverno A. \& Ryan W.B.F. (1986) - Extension in the Tyrrhenian Sea and shortening in the Apennines as result of arc migration driven by sinking of the lithosphere. Tectonics 5, 227-245.

Marani M.P. \& Trua T. (2002) - Thermal constriction and slab tearing at the origin of a superinflated spreading ridge: Marsili volcano (Tyrrhenian Sea). J. Geophys. Res. 107, 2188, 15; doi:10.1029/2001jb000285

Marianelli P., Métrich N., Santacroce R. \& Sbrana A. (1995) - Mafic magma batches at Vesuvius: a glass inclusion approach to the modalities of feeding stratovolcanoes. Contrib. Mineral. Petrol. 120, 159-169.

Marianelli P., Métrich N. \& Sbrana A. (1999) - Shallow and deep reservoir involved in magma supply of the 1944 eruption of Vesuvius. Bull. Volcanol. 61 (1-2), 48-63.

Marianelli P., Sbrana A., Métrich N. \& Cecchetti A. (2005) - The deep feeding system of Vesuvius involved in recent violent Strombolian eruptions. Geophys. Res. Lett., 32, L02306, doi:10.1029/2004GL021667.

Marianelli P., Sbrana A. \& Proto M. (2006) - Magma chamber of Campi Flegrei supervolcano at the time of eruption of the Campanian Ignimbrite. Geology, 34, 937-940.

Marra F., Freda C., Scarlato P., Taddeucci J., Karner D.B., Renne P.R., Gaeta M., Palladino D.M., Trigila R. \& Cavarretta G. (2003) - Post Caldera activity in the Alban Hills Volcanic district (Italy): 40Ar/39Ar geochronology and insights into the magma evolution. Bull. Volcanol. 65, 227-247.

Marra F., Taddeucci J., Freda C., Marzocchi W. \& Scarlato P. (2004) - Recurrence of volcanic activity along the Roman Comagmatic Province (Tyrrhenian margin of Italy) and its tectonic significance. Tectonics, 23, TC4013, doi: 10.1029/2003TC001600.

Marra F., Karner D.B., Freda C., Gaeta M. \& Renne P. (2009) - Large mafic eruptions at Alban Hills Volcanic District (Central Italy): Chronostratigraphy, petrography and eruptive behavior. J. Volcanol. Geother. Res. 179, $217-232$.

Marroni M., Moratti G., Costantini A., Conticelli S., Benvenuti M.G., Pandolfi L., Cornamusini G., Bonini M. \& Laurenzi M.A. (2015) - Geology of the Monte Amiata Region, Southern Tuscany, Central Italy. Ital. J. Geosci. 134, 171-189.

Martelli M., Nuccio P., Stuart F.M., Burgess R., Ellam R.M. \& Italiano F. (2004) - Helium-strontium isotope constraints on mantle evolution beneath the Roman Comagmatic Province, Italy. Earth Planet. Sci. Lett. 224, 295-308.

Mascle J., Kastens K. \& Auroux C. (1988) - A land-locked back-arc basin: preliminary results from ODP Leg 107 in the Tyrrhenian Sea. Tectonophysics 146, 149-162.

Mascle G.H., Tricart P., Torelli L., Bouillin J.P., Rolfo F., Lapierre H., Monié P., Depardon S. Mascle J. \& Peis D. (2001) - Evolution of the Sardinia Channel (Western Mediterranean): new Constraints from a diving survey on Cornacya seamount off SE Sardinia. Mar. Geol. 179, 179-202.

Mattei M., Cipollari P., Cosentino D., Argentieri A., Rossetti F., Speranza F. \& Di Bella L. (2002) - The Miocene tectono-sedimentary evolution of the Southern Tyrrhenian Sea: stratigraphy, structural and paleomagnetic data from the on-shore Amantea basin (Calabrian arc, Italy). Basin Res. 14, 147-168.

Mattei M., Petrocelli V., Lacava D. \& Schiattarella M. (2004) - Geodynamic implications of Pleistocene ultra-rapid vertical-axis rotations in the Southern Apennine (Italy). Geology 32, 9, 789-792. 
Mattei M., Cifelli F. \& D'Agostino N. (2007) - The evolution of the Calabrian Arc: Evidence from paleomagnetic and GPS observations. Earth Planet. Sci. Lett. 263, 259-274.

Mattei M., Funiciello R. \& Parotto M. (2008) - Roma e contesto geodinamico recente dell'Italia Centrale. Mem. Descr. della Carta Geologica d'Italia, LXX(1), 13-24.

Mattei M., Conticelli S. \& Giordano G. (2010) - The Tyrrhenian margin geological setting: from the Apennine orogeny to the Krich volcanism. In: "The Colli Albani Volcano", Funiciello R. \& Giordano G. (eds), The Geol. Soc. London, 7-27.

Mattias P.P. \& Ventriglia U. (1970) - La regione vulcanica dei Monti Sabatini e Cimini. Memorie Soc. Geol. Ital., 9, $331-384$.

McDowell F.W. (1983) - K-Ar dating: incomplete extraction of radiogenic Argon from alkali feldspar. Isotope Geosci. 1, $119-126$.

McKenzie D. (1972) - Active Tectonics of the Mediterranean Region. Geophys. J. Royal Astronom. Soc. 30, $109-185$.

Mele G., Rovelli A., Seber D. \& Barazangi M. (1997) - Shear wave attenuation in the lithosphere beneath Italy and surrounding regions: tectonic implications. J. Geophys. Res. 103, 12529-12543.

Melluso L., Morra V., Perrotta A., Scarpati C. \& Adabbo M. (1995) - The eruption of Breccia Museo (Campi Flegrei, Italy): Fractional crystallization processes in a shallow, zoned magma chamber and implications for the eruptive dynamics. J. Volcanol. Geotherm. Res., 68, 325-339.

Melluso L., Morra V. \& Di Girolamo P. (1996) - The M.te vulture volcanic complex (Italy): evidence for distinct parental magmas and for residual melts with melilite. Mineral. Petrol. 56, 225-250.

Melluso L., Conticelli S., D'Antonio M., Mirco N. \& Saccani E. (2003) - Petrology and mineralogy of wollastonite-melilite-bearing pyrometamorphic rocks from Colle Fabbri and Ricetto, Central Apennines, Italy. Am. Mineral. 88, $1287-1299$.

Melluso L., Conticelli S., D'Antonio M., Mirco N. \& Saccani E. (2005a) - Mineralogic and bulk rock composition of Italian wollastonite- and melilite-bearing paralavas and clinker: Further evidence for their pyrometamorphic nature. Am. Miner. 90, 1926-1933.

Melluso L., Conticelli S., D’Antonio M., Mirco N. \& Saccani E. (2005b) - Wollastonite- anorthite-gehlenite-and fassaite-bearing rocks: Igneous petrological oddity or paralavas? Am. Mineral. 90, 1940-1944.

Melluso L., Conticelli S. \& de' Gennaro R. (2010) - Kirschsteinite in the Capo di Bove melilite leucitite lava (cecilite), Alban Hills, Italy. Mineral. Mag. 74, 887-902

Metrich N., Santacroce R. \& Savelli C. (1986) - Ventotene, a potassic Quaternary volcano in central Tyrrhenian Sea. Rend. Soc. Ital. Mineral. Petrol. 43, 1195-1213.

Metzeltin S. \& Vezzoli L. (1983) - Contributi alla geologia del Vulcano di Latera (Monti Vulsini, Toscana Meridionale- Lazio Settentrionale). Mem. Soc. Geol. It. 25, 247-271.

Micheluccini M., Puxeddu M. \& Toro B. (1971) - Rilevamento e studio Geo-Vulcanologico della regione del M. Cimino (ViterboItalia). Atti Soc. Toscana Sci. Nat. Mem., 78, 301-327.

Mittempergher M. \& Tedesco C. (1963) - Some observations on the ignimbrites, lava domes and lava flows of Monte Cimino (Central Italy). Bull. Volcanol. 25, 343-358.

Mongelli F., Zito G., Cataldi R. et al. (1991) - Geothermal regime of Italy and surrounding seas, in Terrestrial Heat Flow and the Lithosphere Structure (eds. V. Cermák and L. Rybach). Springer-Verlag, Berlin/Heidelberg, 381-394. 
Morhange C., Marriner N., Laborel J., Todesco M. \& Oberlin C. (2006) - Rapid sea-level movements and non eruptive crustal deformation in the Phlegrean Fields caldera, Italy. Geology, 34, 93-96.

Nappi G., Renzulli A. \& Santi P. (1987) - An evolutionary model for the Paleo-Bolsena and Bolsena Volcanic Complexes: a structural and petrographic study. Periodico Mineralogia 56, 241-267.

Nappi G., Renzulli A. \& Santi P. (1991) - Evidence of incremental growth in the Vulsinian calderas (central Italy). J. Volcanol. Geoth. Res. 47, 13-31.

Nappi G., Capaccioni B., Mattioli M., Mancini E. \& Valentini L. (1994) - Plinian fall deposits from Vulsini Volcanic District (Central Italy). Bull. Volcanol. 56, 502-515.

Nappi G., Renzulli A., Santi P. \& Gillot P.-Y. (1995) - Geological evolution and geochronology of the Vulsini Volcanic District (Central Italy). Boll. Soc. Geol. Ital. 114, 599-613.

Nappi G., Antonelli F., Coltorti M., Milani L., Renzulli A. \& Siena F. (1998) - Volcanological and petrological evolution of the Eastern Vulsini District, Central Italy. J. Volcanol. Geoth. Res. 87, 211-232.

Nicoletti M. (1969) - Datazioni Ar-K di alcune vulcaniti delle Regioni vulcaniche Cimina e Vicana. Periodico Mineralogia 38 , 1-20.

Nicoletti M., Petrucciani C., Piro M. \& Trigila R. (1981a) - Nuove datazioni Vulsinee per uno schema di evoluzione dell'attività vulcanica: Il quadrante nord-occidentale. Periodico Mineralogia 48, 153-165.

Nicoletti M., Petrucciani C., Piro M. \& Trigila R. (1981b) - Nuove datazioni Vulsinee per uno schema di evoluzione dell'attività vulcanica: nota II. Il quadrante sud-occidentale. Periodico Mineralogia 50, 141-169.

Nicolosi I., Speranza F. \& Chiappini M. (2006) - Ultrafast oceanic spreading of the Marsili Basin, southern Tyrrhenian Sea: Evidence from magnetic anomaly analysis. Geology 34, 717-720.

Orsi G., D'Antonio M., de Vita S. \& Gallo G. (1992) - The Neapolitan Yellow Tuff, a large-magnitude trachytic phreatoplinian eruption: eruptive dynamics, magma withdrawal and caldera collapse. J. Volcanol. Geotherm. Res., 53, $275-287$.

Orsi G., Civetta L., D'Antonio M., Di Girolamo P. \& Piochi M. (1995) - Step-filling and development of a three-layers magma chamber: the Neapolitan Yellow Tuff case history. J Volcanol Geotherm Res 67, 291-312

Orsi G., Di Vito M. \& de Vita S. (1996) - The restless, resurgent Campi Flegrei Nested Caldera (Italy): constraints on its evolution and configuration. J. Volcanol. Geoth. Res. 74, 179-214.

Orsi G., Civetta L., Del Gaudio C., De Vita S., Di Vito M.A., Isaia R., Petrazzuoli S., Ricciardi G.P. \& Ricco C. (1999) - Short-term ground deformations and seismicity in the nested Campi Flegrei caldera (Italy). J. Volcanol. Geotherm. Res., 91, $415-451$.

Orsi G., Di Vito M.A. \& Isaia R. (2004) - Volcanic hazard assessment at restless Campi Flegrei caldera. Bull. Volcanol., 66, 514-530.

Ort M.H., Rosi M. \& Anderson C.H. (1999) - Correlation of deposits and vent locations of the proximal Campanian Ignimbrite deposits, Campi Flegrei, Italy, based on natural remanent magnetization and anisotropy of magnetic susceptibility characteristics. J. Volcanol. Geotherm. Res. 91, 167-178.

Ort M.H., Orsi G., Pappalardo L. \& Fisher R.V. (2003) - Anisotropy of magnetic susceptibility studies of depositional processes in the Campanian Ignimbrite, Italy. Bull. Volcanol. 65, 55-72.

Owen J.P. (2008) - Geochemistry of lamprophyres from the Western Alps, Italy: implications for the origin of an enriched isotopic component in the Italian mantle. Contrib. Mineral. Petrol. 155, 341-362. 
Palladino D.M., Agosta E., Freda C., Spaziani S. \& Trigila R. (1994) - Studio geo-petrografico dei Vulsini Meridionali, settore Valentano-Marta-La Rocca. Mem. Descr. Carta Geol. d'It., XLIV, 255-276.

Palladino D.M., Gaeta M. \& Marra F. (2001) - A large K-foiditic hydromagmatic eruption from the early activity of the Alban Hills volcanic district. Italy. Bull. Volcanol., 63, 345-359.

Palladino D.M., Simei S., Sottili G. \& Trigila R. (2010) - Integrated approach for the reconstruction of stratigraphy and geology of Quaternary volcanic terranes: an example from the Vulsini volcanoes. Geol. Soc. Am., Spec. Papers 464, 63-84.

Pantosti D., Schwartz D.P. \& Valensise G. (1993) - Paleoseismology Along the 1980 Surface Rupture of the Irpinia Fault: Implications for Earthquake Recurrence in the Southern Apennines, Italy. J. Geophys. Res. 98, 6561-6577.

Paone A. (2004) - Evidence for crustal contamination, sediment and fluid components in the Campanian volcanic rocks. J. Volcanol. Geoth. Res. 138, 1-26.

Pappalardo L., Civetta L., D'Antonio M., Deino A., Di Vito M., Orsi G., Carandente A., de Vita S., Isaia R. \& Piochi M. (1999) Chemical and Sr-isotopical evolution of the Phlegrean magmatic system before the Campanian Ignimbrite and the Neapolitan Yellow Tuff eruptions. J. Volcanol. Geotherm. Res. 91, 141-166.

Pappalardo L., Civetta L., de Vita S., Di Vito M., Orsi G., Carandente A. \& Fisher R.V. (2002a) - Timing of magma extraction during the Campanian Ignimbrite eruption (Campi Flegrei caldera). J. Volcanol. Geotherm. Res., 114, 479-497.

Pappalardo L., Piochi M., D’Antonio M., Civetta L. \& Petrini R. (2002b) - Evidence for Multi-stage Magmatic evolution during the past 60 kys at Campi Flegrei (Italy) deduced from Sr, Nd, and Pb isotope data. J. Petrology 43, 1415-1434.

Parker R.J. (1989) - Geochemical and petrographic characteristics of potassium-rich pyroclastic and lava samples from Vulsini Volcano, Roman Magmatic region, Italy. J. Volcanol. Geoth. Res. 39, 297-314.

Pasquaré G., Chiesa S., Vezzoli L. \& Zanchi A. (1983) - Evoluzione paleogeografica e strutturale di parte della Toscana meridionale a partire dal Miocene superiore. Mem. Soc. Geol. Ital. 25, 145-157.

Patella D. \& Mauriello P. (1999) - The geophysical contribution to the safeguard of historical sites in active volcanic areas. The Vesuvius case-history. J. Appl. Geophys. 41, 241-258.

Peccerillo A. (1985) - Roman Comagmatic Province (Central Italy): Evidence for subduction related magma genesis. Geology $13,103-106$.

Peccerillo A. (1998) - Relationships between ultrapotassic and carbonate-rich volcanic rocks in Central Italy: petrogenetic and geodynamic implications. Lithos 43, 267-279.

Peccerillo A. (1999) - Multiple mantle metasomatism in Central-Southern Italy: Geochemical effects, timing and geodynamic implications. Geology 27, 315-318.

Peccerillo A. (2001) - Geochemical similarities between the Vesuvius, Phlegraean Fields and Stromboli volcanoes: petrogenetic, geodynamic and volcanological implications. Mineral. Petrol., 73, 93-105.

Peccerillo A. (2004) - Carbonate-rich pyroclastic rocks from central Apennines: carbonatites or carbonated rocks? A commentary. Periodico Mineralogia 73, 183-194.

Peccerillo A. (2005a) - Plio-Quaternary Volcanism in Italy: Petrology, Geochemistry, Geodynamics. Springer-Verlag. Berlin, 365 pp.

Peccerillo A. (2005b) - On the nature of carbonate-rich volcanic rocks in Central Italy. A reply to comments by Woolley et al., p.195-204. Periodico Mineralogia 74, 195-204. 
Peccerillo A. \& Taylor S.R. (1976) - Geochemistry of the calc-alkaline volcanic rocks from the Kastamonu area, Northern Turkey. Contrib. Mineral. Petrol. 58, 63-81.

Peccerillo A., Poli G. \& Tolomeo L. (1984) - Genesis, evolution and tectonic significance of K-rich volcanics from the Alban Hills (Roman comagmatic region) as inferred from trace element geochemistry. Contrib. Mineral. Petrol. 86, $230-240$.

Peccerillo A., Conticelli S. \& Manetti P. (1987) - Petrological characteristics and the genesis of the recent magmatism of South Tuscany and North Latium. Periodico Mineralogia, 56, 157-173.

Peccerillo A., Poli G. \& Serri G. (1988) - Petrogenesis of orenditic and kamafugitic rocks from Central Italy. Canad.Mineral. 26 , 45-65.

Peccerillo A. \& Martinotti G. (2006) - The Western Mediterranean lamproitic magmatism: origin and geodynamic significance. Terra Nova 18, 109-117.

Peccerillo A., Federico M., Barbieri M., Brilli M. \& Tsai-Wan Wu (2010) - Interaction between ultrapotassic magmas and carbonate rocks: Evidence from geochemical and isotopic ( $\mathrm{Sr}, \mathrm{Nd}, \mathrm{O}$ ) compositions of granular lithic clasts from the Alban Hills Volcano, Central Italy. Geochim. Cosmochim. Acta 74, 2999-3022.

Perini G. (1997) - Evoluzione magmatologica del vulcano di Vico. Ph.D. Thesis, Dip. Sci. Terra, Univ. of Florence, 327 pp.

Perini G., Conticelli S. \& Francalanci L. (1997) - Inferences on the volcanologcal history of the Vico volcano, Roman Magmatic Province, Central Italy: stratigraphic, petrographic and geochemical data. Mineral. Petrographica Acta 40, 67-93.

Perini G., Conticelli S., Francalanci L. \& Davidson J.P. (2000) - The relationship between potassic and calc-alkaline post-orogenic magmatism at Vico volcano, central Italy. J. Volcanol. Geoth. Res. 95, 247-272.

Perini G. \& Conticelli S. (2002) - Crystallization conditions of Leucite-Bearing magmas and their implications on the magmatological evolution of ultrapotassic magmas: The Vico Volcano, Central Italy. Mineral. Petrol. 74, $253-276$.

Perini G., Tepley F.J. III, Davidson J.P. \& Conticelli S. (2003) - The origin of K-feldspar megacrysts hosted in alkaline potassic rocks: track for low scale mantle heterogeneity. Lithos 66, 223-240

Perini G., Francalanci L., Davidson J.P. \& Conticelli S. (2004) - Evolution and genesis of magmas from Vico Volcano, Central Italy: multiple differentiation pathways and variable parental magmas. J. Petrol. 45, 139-182.

Pialli G., Barchi M.R. \& Minelli G. (1998) - Results of the CROP03 deep seismic reflection profile. Mem. Soc. Geol. Ital. 52 , 65-75.

Piana Agostinetti N., Lucente F.P., Selvaggi G. \& Di Bona M. (2002) - Crustal Structure and Moho Geometry beneath the Northern Apennines (Italy). Geoph. Res. Lett., 29, 1999-2002.

Piochi M., Bruno P.P. \& De Astis G. (2005) - Relative roles of rifting tectonics and magma uprising processes: inferences from geophysical, structural and geochemical data of the Neapolitan volcanic region (southern Italy). Geochem. Geophys. Geosyst., 6, Q07005, doi:10.1029/2004GC000885.

Plank T. (2005) - Constraints from Thorium/Lanthanum on Sediment Recycling at Subduction Zones and the Evolution of the Continents. J. Petrol. 46, 921-944.

Plank T. \& Langmuir C.H. (1998) - The chemical composition of subducting sediments and its consequence for the crust and mantle. Chem. Geol. 145, 325-394.

Poli S., Chiesa S., Gillot P.Y., Gregnanin A. \& Guichard F. (1987) - Chemistry versus time in the Volcanic Complex of Ischia (Gulf of Naples, Italy): evidence of Successive magmatic cycle. Contrib. Mineral. Petrol. 95, 322-335. 
Poli S. (2015) - Carbon mobilized at shallow depths in subduction zones by carbonatitic liquids. Nat. Geosc., 8, $633-636$.

Porreca M., Mattei M., Giordano G., Funiciello R. \& De Rita D. (2003) - Magnetic fabric and implications for emplacement processes of the phreatomagmatic "Peperino di Albano" and related lahar deposits, Albano maar lake (Colli Albani volcano, Italy). J. Geophys. Res., 108 (B5), 2264.

Porreca M., Mattei M., MacNiocaill C., Giordano G., McClelland E. \& Funiciello R. (2008) - Paleomagnetic evidence for low-temperature emplacement of phreatomagmatic Peperino Albano ignimbrite (Colli Albani volcano, Central Italy), Bull. Volcanol., 70, 877-893.

Prelević D., Foley S.F., Romer R.L. \& Conticelli S. (2008) - Mediterranean Tertiary Lamproites: Multicomponent melts in postcollisional geodynamics. Geochim. Cosmochim. Acta, 72, 2125-2156.

Prelević D., Foley S.F., Stracke A., Romer R.L. \& Conticelli S. (2010) - Hf isotope compositions of Mediterranean lamproites: Mixing of melts from asthenosphere and crustally contaminated mantle lithosphere. Lithos, 119, $297-312$.

Prelević D., Brügmann G., Božović M., Foley S.F., Cvetković V. \& Maksimović Z. (2014) - Os-isotopes constraints on the dynamics of orogenic mantle: the case of Central Balkans. Gondwana Res., 27, 1560-1573.

Pyle D.M. (2000) - Sizes of volcanic eruptions. In: Sigurdsson H. et al. (ed). Encyclopedia of volcanoes. Academic Press, $263-269$

Radicati di Brozolo F., di Girolamo P., Turi B. \& Oddone M. (1988) - 40Ar/39Ar e K-Ar dating of K-rich rocks from the Roccamonfina volcano, Roman Comagmatic Region, Italy. Geoch. Cosmoch. Acta, 52, 1435-1441.

Radicati di Brozolo F., Huneke J.C., Papanastassiou D.A. \& Wasserburg G.J. (1981) - 40Ar-39Ar and Rb-Sr age determinations on Quaternary volcanic rocks. Earth Planet. Sci. Lett., 53, 445-456.

Reid M.R. (1995) - Processes of mantle enrichment and magmatic differentiation in the Eastern Snake River Plain: Th isotope evidence. Earth Planet. Sci. Lett., 131, 239-254.

Reid M.R. \& Ramos F.C. (1996) - Chemical dynamics of enriched mantle in the South-Western United States: Thorium isotope evidence. Earth Planet. Sci. Lett., 138, 67-81.

Rogers N.W., Hawkesworth C.J., Parker R.J. \& Marsh J.S. (1985) - The geochemistry of potassic lavas from Vulsini, Central Italy, and implications for mantle enrichment processes beneath the Roman region. Contrib. Mineral. Petrol., 90, $244-257$.

Rolandi G., Maraffi S., Petrosino P. \& Lirer L. (1993a) - The Ottaviano eruption of Somma-Vesuvio (8000 y. B.P.): a magmatic alternating fall and flow-forming eruption. J. Volcanol. Geotherm. Res., 58 (1-4), 43-65.

Rolandi G., Mastrolorenzo G., Barrella A.M. \& Borrelli A. (1993b) - The Avellino plinian eruption of Somma-Vesuvius (3760 y. B.P.): the progressive evolution from magmatic to hydromagmatic style. J. Volcanol. Geotherm. Res., 58, $67-88$.

Rolandi G., Bellucci F., Heizler M.T., Belkin H.E. \& De Vivo B. (2003) - Tectonic controls on the genesis of ignimbrites from the Campanian Volcanic Zone, souther Italy. Mineral. Petrol., 79, 3-31.

Rolandi G., Munno R. \& Postiglione I. (2004) - The A.D. 472 eruption of the Somma volcano. J.Volcanol.Geotherm. Res. 129, 291-319.

Rosenbaum G., Lister G.S. \& Duboz C. (2002) - Reconstruction of the tectonic evolution of the western Mediterranean since the Oligocene. J. Virtual Explorer, 8, 107-130.

Rosenbaum G., Gasparon M., Lucente F.P., Peccerillo A. Miller M.S. (2008) - Kinematics of slab tear faults during subduction segmentation and implications for Italian magmatism, Tectonics, 27, TC2008, doi:10.1029/2007TC002143.

Rosi M. \& Sbrana A. (1987) - The Phlegraean Fields. CNR, Quaderni de 'La ricerca Scientifica', 114, Rome. 
Rosi M., Vezzoli L., Aleotti P. \& De Censi M. (1996) - Interaction between caldera collapse and eruptive dynamics during the Campanian Ignimbrite eruption, Phlegraean Fields, Italy. Bull. Volcanol., 57, 541-554.

Rosi M., Vezzoli L., Castelmenzano A. \& Grieco G. (1999) - Plinian pumice fall deposit of the Campanian Ignimbrite eruption (Phlegraean Fields, Italy). J. Volcanol. Geotherm. Res., 91, 179-198.

Rouchon V., Gillot P.Y., Quidelleur X., Chiesa S. \& Floris B. (2008) - Temporal evolution of the Roccamonfina volcanic complex (Pleistocene), Central Italy. J. Volcanol. Geoth. Res., 177, 500-514.

Sabatini V. (1912) - I Vulcani dell'Italia Centrale e i loro prodotti. Parte II. Vulcani Cimini. Mem. descrittive Carta Geologica d'Italia, 15, 1-636.

Sahama Th.G. (1952) - Leucite, potash nepheline, and clinopyroxene from volcanic lavas from volcanic lavas from Southwestern Uganda and Adjoining Belgian Congo. In: Bowen Volume, pt. II, Am. J. Sci., 457-470.

Sahama Th.G. (1960) - Kalsilite in the lavas of Mt. Nyiragongo (Belgian Congo). J. Petrol., 1, 146 - 171.

Sahama Th.G. (1974) - Potassium Rich Alkaline Rocks. In: "The Alkaline Rocks", Sorensen G. (ed.), John Wiley \& Son, $355-389$.

Santacroce R. (1983) - A general model for the behavior of the Somma-Vesuvius volcanic complex. J. Volcanol. Geotherm. Res., $17,237-248$.

Santacroce R. (1987) - Somma Vesuvius. CNR, Quaderni de 'La ricerca Scientifica', 114, Rome, pp. 251.

Santacroce R., Bertagnini A., Civetta L., Landi P. \& Sbrana S. (1993) - Eruptive Dynamics and Petrogenetic Processes in a very Shallow Magma Reservoir: the 1906 Eruption of Vesuvius. J. Petrology (1993) 34, 383-425. doi: 10.1093/petrology/34.2.383

Santacroce R., Cioni R., Civetta L., Marianelli P., Métrich N. \& Sbrana A. (1994) - How Vesuvius works. In "Large Explosive Eruptions", Atti Conv. Acc. Naz. Lincei, 112, 185-196.

Santacroce R. \& Sbrana A. (Eds.) (2003) - The Vesuvius geological map, CARG Project, Servizio Geologico d'Italia, Naples.

Santacroce R., Cioni R., Marianelli P., Sbrana A., Sulpizio R., Zanchetta G., Donahue D.J. \& Joron J.L. (2008) - Age and whole rock-glass compositions of proximal pyroclastics from the major explosive eruptions of Somma-Vesuvius: a review as a tool for distal tephrostratigraphy. J. Volcanol. Geotherm. Res., 177, 1-18.

Savelli C. (1983) - Età K/Ar delle principali manifestazioni riolitiche dell'Isola di Ponza. Rendiconti Soc. Ital. Mineral.Petrol. 6, $39-42$. Savelli C. (1988) - Late Oligocene to Recent episodes of magmatism in and around the Tyrrhenian Sea: implications for the processes of opening in a young inter-arc basin of intra-orogenic (Mediterranean) type. Tectonophysics, $146,163-181$.

Scaillet S., Vita-Scaillet G. \& Guillou H. (2008) - Oldest human footprints dated by Ar/Ar. Earth Planet. Sci. Lett. $275,320-325$.

Scaillet B., Pichavant M. \& Cioni R. (2008) - Upward migration of Vesuvius magma chamber over the past 20,000 years. Nature, $455,216-219$.

Scandone R., Iannone F. \& Mastrolorenzo G. (1986) - Stima dei parametri dinamici dell'eruzione del 1944 del Vesuvio. Boll. GNV, 2, 487-512.

Scandone R., Bellucci F., Lirer L. \& Rolandi G. (1991) - The structure of the Campanian Plain and the activity of the Neapolitan volcanoes Italy. J. Volcanol. Geotherm. Res., 48, 1-31.

Scarpati C., Cole P. \& Perrotta A. (1993) - The Neapolitan Yellow Tuff - A large volume multiphase eruption from Campi Flegrei, southern Italy. Bull. Volcanol., 55, 343-356. 
Scarpati C. \& Perrotta A. (2012) - Erosional characteristics and behavior of large pyroclastic density currents. Geology, 40, $1035-1038$.

Scarpati C., Perrotta A., Lepore S. \& Calvert A. (2012) - Eruptive history of Neapolitan volcanoes: constraints from 40Ar-39Ar dating. Geol. Mag. 150, 412-425.

Sella G.F., Dixon T.H. \& Mao A. (2002) - REVEL: A model for Recent plate velocities from space geodesy. J. Geophys. Res., 107, 2081-3010.

Selvaggi G. \& Amato A. (1992) - Subcrustal Earthquakes in the Northern Apennines (Italy): Evidence for a Still Active Subduction. Geophys. Res. Lett., 19, 21, 2127-2130.

Skora S. \& Blundy J. (2010) - High pressure hydrous phase relations of radiolarian clay and implication for the involvement of subducting sediment in arc magmatism. J. Petrology 51, 2211-2243.

Signorelli S., Vaggelli G., Francalanci L. \& Rosi M. (1999) - Origin of magmas feeding the Plinian phase of the Campanian Ignimbrite eruption, Phlegrean Fields (Italy): constraints based on matrix-glass and glass-inclusion compositions. J. Volcanol. Geotherm. Res., 91, 199-220.

Sigurdsson H., Carey S., Cornell W. \& Pescatore T. (1985) - The eruption of Vesuvius in A.D. 79. Nat. Geogr. Res. 1, $332-387$.

Smith V.C., Isaia R. \& Pearce N.J.G. (2011) - Tephrostratigraphy and glass compositions of post-15 kyr Campi Flegrei eruptions: implications for eruption history and chronostratigraphic markers. Quaternary Sci. Rev., 30, 3638-3660.

Smith V.C., Isaia R., Engwell S.L. \& Albert P.G. (2016) - Tephra dispersal during the Campanian Ignimbrite (Italy) eruption: implications for ultra-distal ash transport during the large caldera-forming eruption. Bull. Volcanol. June 2016, $78-45$.

Soligo M. \& Tuccimei P. (2010) - Geochronology of Colli Albani volcano. In: "The Colli Albani Volcano", Funiciello R. \& Giordano G. (eds) The Geological Society London, Spec Publ., IAVCEI, 3, 99-106.

Sollevanti F. (1983) - Geologic, Volcanologic and tectonic of the Vico-Cimino Area, Italy. J. Volcanol. Geoth. Res. $17,203-217$.

Sottili G., Taddeucci J., Palladinoa D.M., Gaeta M., Scarlato P. \& Ventura G. (2009) - Sub-surface dynamics and eruptive styles of maars in the Colli Albani Volcanic District, Central Italy. J. Volcanol. Geother. Res. 179, $217-232$.

Sottili G., Palladino D.M., Marra F., Jicha B., Karner D.B. \& Renne P. (2010) - Geochronology of the most recent activity in the Sabatini Volcanic District, Roman Province, central Italy. J. Volcanol. Geoth. Res. 196, 20-30.

Sparks R.S.J. (1975) - Stratigraphy and geology of the ignimbrites of Vulsini Volcano, Central Italy. Geol. Rundschau 64, $497-523$. Speranza F., Villa I.M., Sagnotti L., Florindo F., Cosentino D., Cipollari P. \& Mattei M. (2002) - Age of the Corsica-Sardinia rotation and Liguro-Provencal Basin spreading: New paleomagnetic and Ar/Ar evidences, Tectonophysics 347, $231-251$.

Steiger R.H. \& Jäger E. (1977) - Subcommission on geochronology: Convention on the use of decay constants in geo- and cosmochronology. Earth Planet. Sci. Lett., 36, 359-362.

Stoppa F. (1988) - L'Euremite di Colle Fabbri (Spoleto): litotipo ad affinità carbonatitica in Italia. Boll. Soc. Geol. It. 107, $239-248$. Stoppa F. \& Woolley A.R. (1997) - Italian carbonatites: field occurrence, petrology, regional significance. Mineral. Petrol. 59 , $43-67$. Stoppa F., Rosatelli G., Wall F. \& Jeffries T. (2005) - Geochemistry of carbonatite-silicate pairs in nature: A case history from Central Italy. Lithos, 85, 26-47.

Stoppa F., Principe C. \& Giannandrea P. (2008) - Comments on: Carbonatites in a subduction system: The Pleistocene alvikites from Mt. Vulture (southern Italy) by d'Orazio et al., (2007). Lithos, 103, 550-556. 
Stracke A. \& Hofmann A.W. \& Hart S.R. (2005) - FOZO, HIMU and the rest of the Mantle Zoo. G-Cubed 6, 1-20.

Sun S.S. \& McDonough W.F. (1989) - Chemical and isotopic systematics of oceanic basalts: implications for mantle composition and processes. Geological Society, London, Special Publications, 42. 313-345.

Tappe S., Foley S.F. \& Pearson D.G. (2003) - The kamafugites of Uganda: a mineralogical and geochemical comparison with their Italian and Brazilian analogues: Periodico Mineralogia, v. 72, p. 51-77.

Tommasini S., Avanzinelli R. \& Conticelli S. (2011) - The Thorium/Lanthanum geochemical conundrum of the Tethyan realm lamproites: the role of recycled sediments and zoisite/lawsonite melting. Earth Planet. Sci. Lett. 301, $469-478$.

Tommasini S., Heumann A., Avanzinelli R. \& Francalanci L. (2007) - The Fate of High-Angle Dipping Slabs in the Subduction Factory: an Integrated Trace Element and Radiogenic Isotope (U, Th, Sr, Nd, Pb) Study of Stromboli Volcano, Aeolian Arc, Italy. J. Petrol. 48, 2407-2430.

Treves B. (1984) - Orogenic belts as accretionary prisms: the example of the Northern Apennines. Ofioliti 9, $577-618$.

Trigila R. (A cura di) (1995) - The volcano of the Alban Hills. Tipografia Sgs, Roma, 283 pp.

Tropeano M., Sabato L. \& Pieri P. (2002) - Filling and cannibalization of a foredeep: the Bradanic Trough, Southern Italy. Geological Society, London, Special Publications 191, 55-79.

Tuccimei P., Giordano G. \& Tedeschi M. (2006) - $\mathrm{CO}_{2}$ release variations during the last 2000 years at the Colli Albani volcano (Roma, Italy) from speleothems studies. Earth Planet. Sci. Lett. 243, 449-462.

Turbeville B.N. (1992) - 40Ar/39Ar Ages and Stratigraphy of the Latera caldera, Italy. Bull. Volcanol. 55, $110-118$.

Turbeville B.N. (1993) - Petrology and Petrogenesis of the Latera Caldera, Central Italy. J. Petrol. 34, 77-124

Turner F.J. \& Verhoogen J. (1960) - Igneous and metamorphic petrology, New York, McGraw-Hill, 695p.

Turner S.P., Platt J.P., George R.M.M., Kelley S.P., Pearson D.G. \& Nowell G.M. (1999) - Magmatism associated with orogenic collapse of the Betic-Alboran domain, SE Spain. J. Petrol. 40, 1011-1036.

Valensise G. \& Pantosti D. (2001) - The investigation of potential earthquake sources in peninsular Italy: A review. J. Seismol., 5, 287-306.

Van der Voo R. (1993) - Paleomagnetism of the Atlantic, Tethys, and Iapetus oceans. Cambridge University Press, 1-413.

Varekamp J.C. (1979) - Geology and Petrology of the Vulsini Volcanic area, Latium, Italy. Geologica Ultraiectina, $22,1-380$.

Varekamp J.C. (1980) - Vulsinian area, Lazio, Italy. Bull. Volcanol. 43. 489-503.

Varekamp J.C. \& Kalamarides R.I. (1989) - Hybridization Processes in Leucite Tephrites From Vulsini, Italy, and the Evolution of the Italian Potassic Suite. J. Geophys. Res. 94: 4603-4618.

Ventura G., Vilardo G., Bruno P.P. (1999) - The role of flank failure in modifying the shallow plumbing system of volcanoes: an example from Somma-Vesuvius, Italy. Geophys. Res. Lett., 26, 3681-3684

Vezzoli L., Conticelli S., Innocenti F., Landi P., Manetti P., Palladino D.M. \& Trigila R. (1987) - Stratigraphy of the Latera Volcanic complex: proposal for a new nomenclature. Periodico Mineralogia 56, 85-110.

Vilardo G., Isaia R., Ventura G., De Martino P., Terranova C. (2010) - InSAR Permanent Scatterer analysis reveals fault reactivation during inflation and deflation episodes at Campi Flegrei caldera. Remote Sensing of Environment, 114, 2373-2383. 
Villa I.M., Calanchi N., Dinelli E., Lucchini F. (1999) - Age and evolution of the Albano crater lake (Roman Volcanic Province). Acta Vulcanologica, 11 (2), 305-310.

Villa I.M., Giuliani O., De Grandis G., Cioni R. (1989) - Datazioni K/Ar dei vulcani di Tolfa e Manziana (in Italian). Bollettino Gruppo Nazionale di Vulcanologia, 5, 1025-1026.

Villemant B. \& (1988) - Trace element evolution in the Phlegrean Fields (Central Italy) : fractional Crystallization and selective enrichment. Contrib. Mineral. Petrol. 98. 169-183.

Villemant B. \& Fléhoc C. (1989) - U-Th fractionation by fluids in K-rich magma genesis: the Vico volcano, Central Italy. Earth Planet. Sci. Lett. 91, 312-326.

Villemant B., Trigila R. \& De Vivo B. (1993) - Geochemistry of Vesuvius volcanics during 1631-1944 period. J. Volcanol. Geoth. Res. 58, 291-313.

Vinkler A.P., Cashman K., Giordano G. \& Groppelli G. (2012) - Evolution of the mafic Villa Senni caldera-forming eruption at Colli Albani volcano, Italy, indicated by textural analysis of juvenile fragments. J. Volcanol. Geoth. Res. 235-236, 37-54.

Vitale S. \& Isaia R. (2014) - Fractures and faults in volcanic rocks (Campi Flegrei, southern Italy): Insight into volcano-tectonic processes. Inter. J. Earth Sci., 103, 801-819.

Vollmer R. (1989) - On the Origin of the Italia Potassic Magmas. 1. a discussion contribution. Chem. Geol. 74, $229-239$.

Vollmer R. \& Hawkesworth C.J. (1980) - Lead isotopic composition of the potassic rocks from Roccamonfina (South Italy). Earth Planet. Sci. Lett., 47, 91-101.

Walker R.J., Carlson R.W., Shirey S.B. \& Boyd F.R. (1989) - Os, Sr, Nd, and Pb isotope systematics of southern African peridotite xenoliths: Implications for the chemical evolution of subcontinental mantle. Geoch. Cosmoch. Acta 53, $1583-1595$.

Ward S.N. (1994) - Constraints on the seismotectonics of the Central Mediterranean from Very Long-Base-Line Interferometry. Geophys. J. Intern., 117, 441-452.

Washington H.S. (1906) - The Roman Comagmatic Region. Carnegie Institution of Washington 36, 1-220.

Watkins S.D., Giordano G., Cas R.A.F. \& De Rita D. (2002) - Variation in mafic pyroclastic density current deposits caused by preeruptive depositional surface characteristics: the Villa Senni Eruption Unit, Alban Hills volcano (Rome, Italy). J. Volcan. Geotherm. Res., 118, 173-204

Watts M.D. (1987) - Geothermal exploration of Roccamonfina volcano, Italy. Geothermics 16, 527-528.

Westaway R., Jackson J. (1984) - Surface faulting in the southern Italian Campania-Basilicata earthquake of 23 November 1980. Nature, 312, $436-438$.

Widom E., Gaddis S.J. \& Well N.E. (2004) - Re-Os isotope systematic in carbonates from Serpent Mound, Ohio: Implications for Re-Os dating of crustal rocks and Ordovician seawater Os composition. Geoch.Geoph. Geosyst., 5.

Wohletz K., Orsi G. \& de Vita S. (1995). Eruptive mechanisms of the Neapolitan Yellow Tuff interpreted from stratigraphie, chemical, and granulometric data. J. Volcanol. Geother. Res. 67, 263-290.

Wood D.A. (1979) - A variably veined suboceanic upper mantle-Genetic significance for mid-ocean ridge basalts from geochemical evidence. Geology, 7, 499-503. 
Woolley A.R., Bailey D.K., Castorina F., Rosatelli G., Stoppa F. \& Wall F. (2005) - Reply to: "Carbonate-rich pyroclastic rocks from central Apennines: carbonatites or carbonated rocks? A commentary". A. Peccerillo, 183-194. Periodico Mineralogia, 74, 195-204. Wortel M.J.R. \& Spakman W. (2000) - Subduction and Slab Detachment in the Mediterranean-Carpathian Region. Science, 290, 1910-1917.

Yoder H.S. Jr (1973) - Melilite stability and paragenesis. Fortschritte der Mineralogie, 50, $140-173$.

Yoder H.S. Jr (1979) - Melilite-bearing rocks and related lamprophyres. In: "The Evolution of the Igneous rocks: fiftieth anniversary perspective", Princeton University Press, 391-411.

Yoder H.S. Jr. (1986) - Potassium-rich Rocks: Phase Analysis and Heteromorphic Relations. J. Petrol., $27,1215-1228$.

Zollo A., Gasparini P., Virieux J., Biella G., Boschi E., Capuano P., de Franco R., Dell'Aversana P., de Matteis R., De Natale G., Iannaccone G., Guerra I., Le Meur H. \& Mirabile L. (1998) - An image of Mt. Vesuvius obtained by 2D seismic tomography. J. Volcanol. Geotherm. Res., 82, 161-173.

Zou H., Reid M. R., Liu Y., Yao Y., Xu X. \& Fan Q (2003) - Constraints on the origin of historic potassic basalts from northeast China by U-Th disequilibrium data. Chem. Geol., 200, 189-201.

Editorial responsability and handling by $\mathrm{R}$. Cioni 